\title{
PARTICIPAÇÃO DO CONTRIBUINTE NA EDIÇÃO DE REGULAMENTAÇÃO TRIBUTÁRIA
}

DISSERTAÇÃO DE MESTRADO

Orientador: Professor Heleno Taveira Torres

Faculdade de Direito da Universidade de São Paulo São Paulo

2010 


\title{
Antonio Carlos de Almeida Amendola
}

(n. USP 5540263)

\section{PARTICIPAÇÃO DO CONTRIBUINTE NA EDIÇÃO DE REGULAMENTAÇÃO TRIBUTÁRIA}

\author{
Dissertação apresentada à \\ Banca Examinadora da \\ Universidade de São Paulo, \\ como exigência parcial para a \\ obtenção do título de Mestre em \\ Direito
}

Orientador: Professor Heleno Taveira Torres

Faculdade de Direito da Universidade de São Paulo São Paulo

2010 
Banca Examinadora 
Aos meus pais, pelo amor, estímulo e exemplo. 


\section{RESUMO}

Este trabalho objetiva discutir o direito de participação do contribuinte na edição da regulamentação tributária em um processo administrativo específico. Dada a maior relevância que vem sendo atribuída à regulamentação fiscal em algumas situações na atualidade, essas normas infralegais por si só não são suficientes para legitimar o seu importante papel, devendo haver um processo prévio e regulado que permita a participação do contribuinte, bem como a supervisão de todas as etapas necessárias para a sua edição.

Para abordar e discutir o referido processo regulamentar, parte-se da análise do princípio da legalidade e da sua importância no Estado de Direito. Verifica-se, na sequência, o conceito de regulamentação tributária adotado nesse trabalho, os tipos de regulamentos, bem como a relevância da regulamentação tributária na atualidade, inclusive sob a luz da jurisprudência do Supremo Tribunal Federal. Aborda-se então o princípio da separação de poderes e o debate acerca da sua violação diante do maior poder normativo exercido pelo Executivo. Nesse ponto, explora-se também a experiência norte-americana na instituição de um processo para edição da regulamentação em geral, inclusive a tributária. Finalmente, discutem-se os princípios jurídicos que justificam a instituição de um processo para a edição da regulamentação tributária com a participação do contribuinte no Brasil, com destaque para a legalidade processual. 


\section{RIASSUNTO}

Questo lavoro ha come scopo discutere il diritto di partecipazione del contribuente nell'edizione della regolamentazione tributaria su un processo amministrativo specifico. In virtù della particolare rilevanza attribuita oggigiorno alla regolamentazione fiscale in certe situazioni, tali norme infralegali da sole non sono sufficienti per rendere legittimo il loro importante ruolo, dovendo precedere un processo regolato che permetta la partecipazione del contribuente, nonché la supervisione di tutte le fasi necessarie per la loro edizione.

Per trattare e discutere il processo regolamentare si parte dall'analisi del principio della legalità e della loro importanza nello Stato di Diritto. Di seguito è esposto il concetto di regolamentazione tributaria adottato su questo lavoro, i tipi di regolamenti, nonché la rilevanza attuale della regolamentazione tributaria, pure alla luce della giurisprudenza del Supremo Tribunale Federale. Si tratta allora del principio della separazione di poteri e il dibattito circa la loro violazione di fronte al più intenso potere normativo svolto dall'Esecutivo. A questo punto, si esplora pure l'esperienza nordamericana nell'adozione di un processo per l'edizione della regolamentazione in genere, ivi inclusa quella tributaria. Alla fine si discutono i principi giuridici che giustificano l'adozione di una procedura per l'edizione della regolamentazione tributaria con la partecipazione del contribuente in Brasile, con rilievo alla legalità processuale. 
"Mas afinal, o que é o próprio governo senão o maior de todos os reflexos da natureza humana? Se os homens fossem anjos, não seria necessário haver governos. Se os homens fossem governados por anjos, dispensar-se-iam os controles internos e externos. Ao constituir-se um governo - integrado por homens que terão autoridade sobre outros homens - a grande dificuldade está em que se deve, primeiro, habilitar o governante a controlar o governado e, depois, obrigá-lo a controlar-se a si mesmo." (James Madison. O Federalista) 


\section{SUMÁRIO}

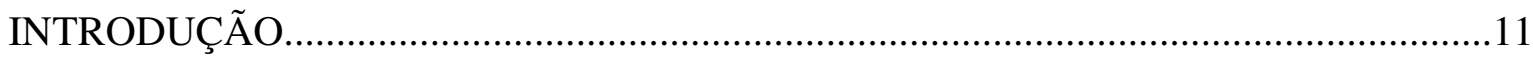

I - O PRINCÍPIO DA LEGALIDADE NO SISTEMA TRIBUTÁRIO

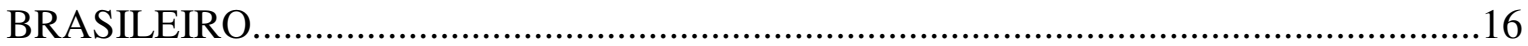

I.A Alguns Aspectos do Estado Democrático de Direito......................................16

I.A.1 Direitos Fundamentais..........................................................................18

I.A.2 Limitações ao Poder de Tributar...........................................................20

I.A.3 Separação de Poderes........................................................................23

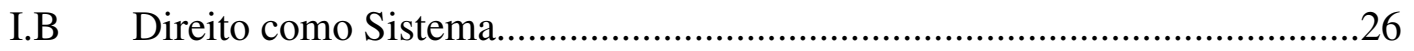

I.C Fontes do Direito Tributário. Constituição, Lei e Regulamento e a Competência Tributária................................................................................29

I.D O Princípio da Legalidade Tributária.................................................................

I.D.1 Valores Protegidos pela Legalidade Tributária: Liberdade e

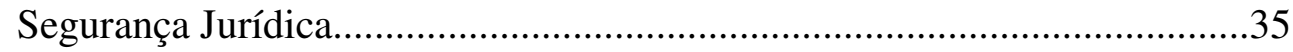

I.D.2 Conteúdo do Princípio da Legalidade Tributária.................................38

I.D.2.1 Problemática do Aspecto Material..........................................40

I.D.2.2 Problemática do Aspecto Formal............................................49

I.D.3 Último Comentário sobre a Problemática do Princípio da Legalidade Tributária.

I.E O Princípio da Legalidade e as Obrigações Acessórias / Deveres Instrumentais.......................................................................................

II - A REGULAMENTAÇÃO TRIBUTÁRIA E A “NORMA ESPELHO”.......................61

II.A Delimitação do Conceito de Regulamentação Tributária................................61

II.B Fundamento do Poder Regulamentar............................................................63

II.C Dever de Editar a Regulamentação Tributária................................................65

II.D Teste de Harmonia da Regulamentação Tributária / Construção da "Norma Espelho". 
II.D.1 Determinação Semântica.

II.D.2 Individualização Normativa..........................................................70

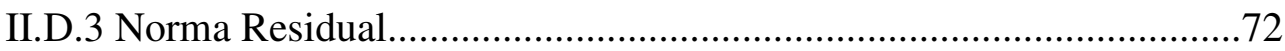

II.E Tipos de Regulamento (Regulamentação Tributária).................................72

II.E.1 Regulamentação Tributária Intra Legem em Litígio no Supremo Tribunal Federal...............................................................................

II.E.1.1. Caso do Valor Venal - Base de Cálculo do

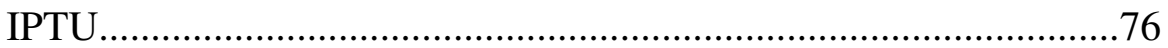

II.E.1.2. Caso da Taxa de Fiscalização Ambiental..................77

II.E.1.3 Caso dos Semi-elaborados - Incidência de ICMS....78

II.E.1.4 Caso da Substituição Tributária - Margem de Valor Agregado - ICMS..................................................79

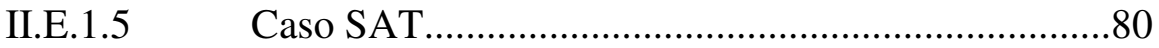

II.E.1.6 Comentário Analítico...............................................81

II.F Crítica à Regulamentação Tributária - Casos Concretos.............................84

II.F.1 Omissão na Edição da Regulamentação Tributária - Caso da Exclusão das Receitas de Terceiros da Base de Cálculo do PIS/COFINS..............84

II.F.2 Indevida Inovação da Ordem Jurídica - Caso da Alteração da Fórmula do PRL 60\% em Instrução Normativa................................................86

II.F.3 Exercício do Poder Regulamentar de Forma Não Transparente - Caso do ICMS-ST de Aparelhos Celulares no Estado de São Paulo............88

III - A FLEXIBILIZAÇÃO DA LEGALIDADE TRIBUTÁRIA E A SEPARAÇÃO DE

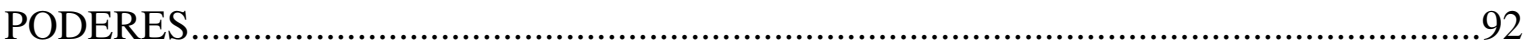

III.A O Desenvolvimento do Estado Regulatório...................................................93

III.A.1 Nos Estados Unidos.................................................................93

III.A.1.1 O Caso Chevron...............................................................100

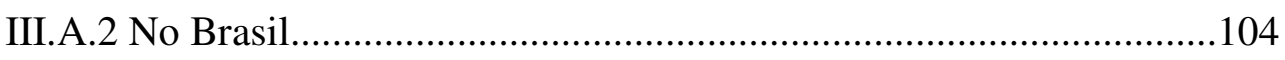

III.B O Direito Tributário no Estado Regulatório..................................................110

III.B.1 Nos Estados Unidos..............................................................110 
III.C Reequilíbrio de Poderes/Funções.

IV - PARTICIPAÇÃO DO CONTRIBUINTE NA EDIÇÃO DA REGULAMENTAÇÃO TRIBUTÁRIA

IV.A A Flexibilização da Legalidade Tributária e a Necessidade do Processo Regulamentar.

IV.B O Princípio da Legalidade Processual - Da Regulamentação Tributária ao Processo Regulamentar com a Participação do Contribuinte.

IV.C Outros Fundamentos para Participação do Contribuinte na Edição da Regulamentação Tributária......................................................................134

IV.C.1 Princípio do Devido Processo Legal............................................134

IV.C.2 Princípio da Motivação................................................................137

IV.C.3 Princípio da Isonomia Tributária................................................140

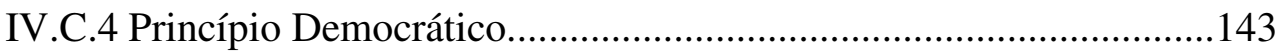

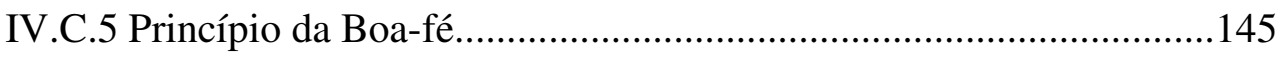

IV.C.6 Princípio da Transparência Tributária.............................................147

IV.C.7 Princípio da Eficiência................................................................148

IV.D Benefícios da Participação do Contribuinte na Edição da Regulamentação Tributária.

IV.E Inexistência de Disponibilidade de Interesse Público...............................152

IV.F Não Caracterização de Crime de Tráfico de Influência................................153

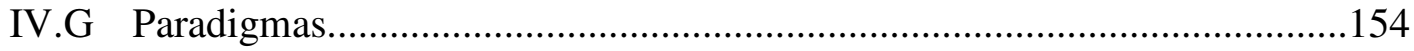

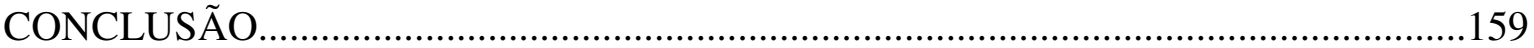

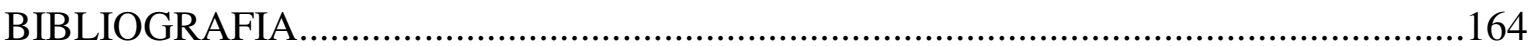




\section{INTRODUÇ̃̃o}

Concomitantemente ao fortalecimento do Estado Social e Democrático de Direito no Brasil, à crescente necessidade de financiar os gastos públicos respectivos e ao desenvolvimento da vida econômica e das diferentes formas de fazer negócios, o sistema tributário brasileiro se tornou e continua a se tornar muito complexo, ${ }^{1}$ o que acarreta a perda de clareza e de simplicidade das normas tributárias. Nesse contexto, implantou-se uma inflação legislativa ${ }^{2,3,4}$ a fim de regular os tributos nacionais, o que dificulta a concretização pacífica da legislação tributária. ${ }^{5,6}$

Como consequência da complexidade do sistema tributário, a Administração Tributária e o contribuinte vêm se distanciando cada vez mais em posições antagônicas diante da legislação tributária, sendo que ambos se encontram em estado de desconfiança em relação ao outro. ${ }^{7}$

\footnotetext{
${ }^{1}$ A complexidade da legislação tributária pode se manifestar de diversas formas. O Professor David F. Bradford classifica a complexidade do sistema tributário em três classes: (i) rule complexity (complexidade na interpretação da norma); (ii) compliance complexity (complexidade na determinação do crédito tributário e na satisfação de obrigações acessórias); e (iii) transactional complexity (complexidade experimentada pelo contribuinte para, na organização e condução de suas atividades, identificar e otimizar a carga tributária diante do sistema tributário existente). (BRADFORD, David F. Untangling the Income Tax. Cambridge: Harvard University Press, 1999. p. 266). Não há dúvida de que essas três espécies de complexidade estão presentes no ordenamento tributário brasileiro.

${ }^{2}$ O Professor Paulo de Barros Carvalho afirma que "no campo tributário, os diplomas têm se sucedido em velocidade espantosa, sem que a cronologia corresponda a um plano preordenado e com a racionalidade que o intérprete almejaria encontrar." (CARVALHO, Paulo de Barros. Curso de Direito Tributário. 18. ed. São Paulo: Editora Saraiva, 2007. p. 5.)

${ }^{3}$ Fenômeno similar ocorre na Alemanha e na Itália, como relata o Ricardo Lobo Torres. (TORRES, Ricardo Lobo. Tratado de Direito Constitucional Financeiro e Tributário. Volume II. Valores e Princípios Constitucionais Tributários. Rio de Janeiro: Editora Renovar, 2005. p. 465.).

${ }^{4}$ Este mesmo fenômeno acontece na Argentina também, como aponta Héctor B. Villegas. (VILLEGAS, H. B. Principio de Seguridad Jurídica en la Creación y Aplicación del Tributo - El Contenido de la Seguridad Jurídica. Revista de Direito Tributário. São Paulo, RT, v. 66, p. 13, 1995.)

${ }^{5} \mathrm{O}$ World Economic Forum, com apoio da Fundação Dom Cabral, examinou a eficiência do sistema tributário de 134 países. Nessa análise, o Brasil foi classificado em último lugar $\left(116^{\circ}\right.$ lugar com relação à carga tributária imposta). Nesse estudo, foi identificado que o principal problema para fazer negócios no Brasil está relacionado com a complexidade das "tax regulations". (WORLD ECONOMIC FORUM. The Global Competitiveness Report 2008/2009. Genebra: World Economic Forum, 2008 e The Brazil Competitiveness Report 2009. Genebra: World Economic Forum, 2009).

${ }^{6}$ A complexidade do sistema tributário brasileiro e a inflação legislativa motivaram Alfredo Augusto Becker a afirmar a existência de um "manicômio jurídico tributário" e de um estado de "demência" no Brasil. (BECKER, Alfredo Augusto. Teoria Geral do Direito Tributário. 3. ed. São Paulo: Lejus, 1998. p. 3-7).

${ }^{7}$ Ricardo Mariz de Oliveira aponta a existência de uma atmosfera beligerante na qual se encontram fisco e contribuinte, tendo em vista as atitudes do primeiro em detrimento do contribuinte. (OLIVEIRA, Ricardo Mariz. Em defesa da Ordem Tributária Institucional. Revista de Direito Bancário e do Mercado de Capitais, São Paulo, Editora Revista dos Tribunais, n. 28, p. 44, abril/junho 2005.).
} 
Na edição da legislação tributária (via lei e medida provisória com força de lei), o Poder Legislativo e o Poder Executivo devem cumprir a multifacetada tarefa de: (i) arrecadar recursos públicos para que os objetivos do Estado Social e Democrático de Direito possam ser alcançados, atividade essa que tem sido desenvolvida inclusive sob a luz das peculiaridades de determinados setores da economia; (ii) induzir um determinado comportamento do contribuinte (estimular a economia ou setores dessa, proteger o meio ambiente, reduzir demissões em época de crise, reduzir desigualdades regionais etc.), fenômeno conhecido como extrafiscalidade; (iii) instituir obrigações acessórias ou deveres instrumentais que proporcionem a maior transparência possível das atividades do contribuinte, com o escopo de possibilitar a verificação da ocorrência de fatos geradores; e (iv) simplificar o sistema tributário nacional o máximo possível, tendo em vista a necessidade de uma fiscalização de massa em um país de dimensão continental.

Nessa complexa atividade de produção normativa, o Poder Legislativo e o Poder Executivo empregam conceitos ambíguos e indeterminados, presunções, sendo que, em alguns casos, chegam até mesmo a produzir normas de lógica duvidosa, cuja aplicação se mostra complicada. ${ }^{8}$ Em algumas ocasiões, em virtude da complexidade da vida econômica atual, a atividade normativa desempenhada por tais Poderes, por meio de lei ou de medida provisória, não consegue estabelecer o regramento tributário almejado de forma completa, atribuindo-se à regulamentação um papel complementar relevante.

Nesse cenário, a lei ordinária propriamente dita vem perdendo a força de contenção da Administração Tributária do passado, a qual vai sendo paulatinamente capturada pela regulamentação tributária. Em muitos casos a lei faz reenvios intencionais para a regulamentação fiscal e o próprio Supremo Tribunal Federal admitiu que o regulamento tem aptidão para preencher conceitos indeterminados utilizados em lei com dados da realidade. O caso da contribuição ao seguro de acidentes do trabalho é um exemplo (“SAT” - RE n. 343.446-SC; julgamento: 20.03.2003; DJU: 04.04.2003).

\footnotetext{
${ }^{8}$ Nessa mesma linha, mas na Alemanha, Klaus Tipke afirma que os "legisladores tributários tendem a decidir sobre leis tributárias sem refletir como elas devem ser executadas. Entre outros, eles chegam até a deixar as autoridades fiscais perdidas, ao proibir o esclarecimento da lei ou ao criar impedimentos à sua execução." (TIPKE, Klaus. A Necessidade de Igualdade na Execução das Leis Tributárias. Tradução: Luís Eduardo Schoueri. In: SCHOUERI, Luís Eduardo (coord.). Direito Tributário- Homenagem a Alcides Jorge Costa. Vol. I. São Paulo: Quartier Latin, 2003. p. 372).
} 
Por sua vez, o contribuinte experimenta dificuldade, mesmo sob a luz da regulamentação fiscal, para entender e aplicar a complexa legislação tributária, bem como para cumprir os inúmeros deveres instrumentais existentes. Pior, muitas vezes a regulamentação é exatamente a causa de dúvidas de como a legislação tributária deve ser aplicada, não sendo ela mesma um instrumento de contenção da Administração Tributária.

Em virtude das circunstâncias acima, marcadas pela insegurança jurídica, existem inúmeros processos envolvendo disputas tributárias no Poder Judiciário, de tal sorte que o último se encontra em estado de calamidade. Do mesmo modo, também existe nas cortes administrativas um volume expressivo de processos tributários.

Logo, a premissa do presente trabalho é a atual complexidade do sistema tributário brasileiro, a maior importância que vem sendo atribuída à regulamentação tributária e o consequente e claro conflito entre o contribuinte e a Administração Tributária. Nesse ambiente beligerante, o Chefe do Poder Executivo e a Administração Tributária deixam de ser considerados agentes fiduciários da sociedade e as normas infralegais por esses editadas perdem legitimidade, no sentido de não serem vistas pelo contribuinte como uma forma efetiva de regulamentação da legislação, mas sim como uma ferramenta de arrecadação. Tais normas deixam de ser consideradas úteis na interpretação da lei tributária e passam a ser muitas vezes ignoradas e questionadas.

Muito se tem discutido acerca de meios alternativos de solução de controvérsias tributárias, mas também devem ser pensados e estudados, além do instituto da consulta e dos chamados acordos prévios de preços de transferência, mecanismos para prevenir litígios fiscais e simplificar o cumprimento de deveres instrumentais, como o processo de edição de regulamentação tributária estudado no presente trabalho, inspirado no rule making norte-americano, que envolve o chamado notice-and-comment.

Dada a maior relevância que vem sendo atribuída à regulamentação fiscal na atualidade, essas normas infralegais por si só não são suficientes para legitimar o seu importante papel, devendo haver um processo prévio e regulado que permita a participação do contribuinte, bem como a supervisão de todas as etapas necessárias para a sua edição. 
Para abordar e discutir o referido processo regulamentar, parte-se da análise do princípio da legalidade tributária e da sua importância no Estado de Direito. Verifica-se, na sequência, o conceito de regulamentação tributária adotado nesse trabalho, os tipos de regulamentos, bem como a relevância da regulamentação tributária na atualidade, inclusive sob a luz da jurisprudência do Supremo Tribunal Federal. Aborda-se então o princípio da separação de poderes e o debate acerca da sua violação diante do maior poder normativo exercido pelo Executivo. Nesse ponto, explora-se também a experiência norte-americana na instituição de um processo para edição da regulamentação em geral, inclusive a tributária. Finalmente, discutem-se os princípios jurídicos que justificam a instituição de um processo para a edição da regulamentação tributária com a participação do contribuinte no Brasil.

Esse processo de produção normativa regulamentar permitirá a prévia e efetiva participação do contribuinte na edição de regulamentação fiscal, o que ocorre hoje apenas em situações muito específicas e de forma precária. $\mathrm{O}$ ato final do processo administrativo a ser examinado será a própria regulamentação tributária, acompanhada de uma exposição de motivos cuja publicidade será dada.

Espera-se que a utilização desse processo de forma adequada, mediante a cooperação mútua e sincera entre fisco e contribuinte, viabilize a produção de normas infralegais de melhor qualidade. Tal processo proporcionará maior segurança jurídica e a aplicação isonômica da lei de forma efetiva, bem como evitará a distorção ou atropelo de conceitos jurídicos e a edição de regulamentação tributária arbitrária. A motivação da regulamentação fiscal dará maior transparência à posição da Administração Tributária acerca do conteúdo da lei e, dependendo dos fundamentos utilizados, maior legitimidade, com uma maior aceitação das normas infralegais editadas.

Tudo isso, obviamente, deve contribuir para a melhora da percepção do Chefe do Poder Executivo e da Administração Tributária pelo contribuinte, o qual continuará contando com a revisão do Poder Judiciário, que, além do exame do conteúdo das normas infralegais propriamente ditas, já realizado hoje, poderá analisar os motivos adotados na edição de tais normas, possibilitando uma efetiva contenção do Poder Executivo com uma melhor proteção dos direitos fundamentais do contribuinte. 
Cumpre frisar que esse estudo não objetiva, de modo algum, uma maior flexibilização ou enfraquecimento do princípio da legalidade tributária diante do seu estado atual. Muito pelo contrário. O presente trabalho busca abordar um processo administrativo que obrigue a Administração Tributária a exercer o seu dever de regulamentar de modo adequado, dentro dos limites da lei e de forma transparente, de tal maneira que a regulamentação ao final editada contribua para proporcionar maior segurança jurídica.

Também é importante salientar, desde logo, que o presente estudo não pretende atribuir voz ampla e irrestrita a qualquer contribuinte que deseje participar do processo de edição de regulamentação tributária. Como se discute neste estudo, o direito a participação em tal processo terá caráter exclusivamente técnico, apolítico. 


\section{CAPÍTULO I - O PRINCÍPIO DA LEGALIDADE NO SISTEMA TRIBUTÁRIO BRASILEIRO}

Para tratar do princípio da legalidade tributária, é importante ter em mente a noção geral de Estado Democrático de Direito.

\section{I.A Alguns Aspectos do Estado Democrático de Direito}

Inicialmente, cabe mencionar que a República Federativa do Brasil constitui um Estado de Direito, como o próprio artigo $1^{\circ}$ da Constituição Federal expressamente reconhece e impõe, em sintonia com todos os princípios, direitos e garantias previstos na Carta Magna.

Muito embora o conceito de Estado de Direito não seja unívoco e encontre-se em constante evolução, variando em cada país e no tempo, ${ }^{9}$ pode-se afirmar com tranquilidade que o objetivo do Estado de Direito é a proteção dos direitos fundamentais. ${ }^{10}$ As principais características do Estado de Direito são: a supremacia da constituição, a separação de poderes, a superioridade da lei, as limitações constitucionais ao poder de tributar, e as garantias processuais dos direitos fundamentais. ${ }^{11}$

O Estado de Direito foi construído como forma de proteção dos direitos fundamentais, inclusive como meio de proteção diante do poder fiscal irresistível exercido nas monarquias absolutistas. ${ }^{12}$ Com efeito, as revoluções norte-americana e francesa, que desencadearam a independência das treze colônias e a queda da bastilha foram motivadas, entre outras razões, pela imposição de tributos sem consentimento do contribuinte e pelo

\footnotetext{
${ }^{9}$ Sobre as variações do Estado de Direito na Alemanha, Inglaterra, Estados Unidos e França, cabe fazer referência ao estudo de Danilo Zolo (ZOLO, Danilo. Teoria e Crítica do Estado de Direito. In: ZOLO, Danilo; COSTA, Pietro (orgs.). O Estado de Direito - História, Teoria, Crítica. Tradução: Carlo Alberto Dastoli. São Paulo: Martins Fontes, 2006. p. 11).

${ }^{10}$ GORDILlO, Augustin. Princípios Gerais de Direito Público. Tradução: Marco Aurélio Grecco. São Paulo: Revista dos Tribunais, 1977. p. 68.

${ }^{11}$ MENDES, Gilmar. Proteção Judicial Efetiva dos Direitos Fundamentais. In: LEITE, George Salomão; SARLET, Ingo Wofgang (coord.). Direitos Fundamentais e Estado Constitucional: Estudos em Homenagem a J.J. Gomes Canotilho. São Paulo: Editora Revista dos Tribunais; Coimbra (Pt): Coimbra Editora, 2009. p. 400.

12 JARACH, Dino. Curso Superior de Derecho Tributario. Buenos Aires: Editora Nueva Buenos Aires, 1969. p. 24, 101-102.
} 
descontentamento decorrente de desigualdade tributária. ${ }^{13,14,15}$ Tais revoluções objetivavam assegurar os direitos fundamentais dos povos que se insurgiram diante do poder dominante, que era opressivo. ${ }^{16}$

O surgimento do Estado de Direito por meio das referidas revoluções pretendia substituir o governo dos monarcas absolutos, dos homens, pelo governo do Direito, das leis, as quais deveriam garantir a liberdade e proporcionar uma situação de segurança jurídica. A lei, produzida por representantes do povo, condicionava o exercício do poder pelos homens e assegurava a liberdade individual. Dessa maneira, a legalidade surgiu com o Estado de Direito com o status de um valor supremo, cuja intensidade é materializada na constituição. $^{17}$

As constituições editadas em razão das mencionadas revoluções estabeleciam a separação de poderes no Estado de Direito como meio de evitar a sua concentração em um só homem ou grupo de homens, o que poderia levar ao abuso e ao excesso. Nos dois casos, a constituição definia e fixava a competência, a função que cada Poder exerceria no Estado de Direito e as limitações de um Poder por outro Poder, o que é tratado adiante mais detalhadamente. ${ }^{18}$

Com o aperfeiçoamento do Estado de Direito, verificou-se a importância da legitimidade democrática do poder como forma efetiva de proteção dos particulares diante dos avanços abusivos e injustos da Administração Pública. Com base na soberania popular, foram instituídos mecanismos de participação dos particulares no processo de criação do ordenamento jurídico. A participação dos particulares na criação do ordenamento jurídico constitui medida democrática que estabelece uma relação de conexão

\footnotetext{
${ }^{13}$ TORRES, Ricardo Lobo. A Ideia de Liberdade no Estado Patrimonial e no Estado Fiscal. Rio de Janeiro: Renovar, 1991. p. 114, 145-146.

14 Eduardo Domingos Bottallo reporta a desigualdade tributária entre as classes na França, antes da revolução. BOTTALLO, Eduardo Domingos. Teoria da Divisão dos Poderes: Antecedentes Históricos e Principais Aspectos. Revista de Direito da Faculdade de São Bernardo do Campo, São Bernardo do Campo, ano 12, n. 14, p. 136, 2008.

${ }^{15}$ COMPARATO, Fabio Konder. A Afirmação Histórica dos Direitos Humanos. São Paulo: Saraiva, 2001. p. 98 e 130.

${ }_{16}$ Antes dessas constituições, também com a sua fundamental parcela de colaboração para a configuração do Estado de Direito atual, deve-se mencionar a Magna Carta de 1215 (na qual o rei João Sem-Terra se comprometeu perante a nobreza a reconhecer formalmente os seus direitos como condição para cobrança de impostos) e o Bill of Rights inglês de 1689 (no qual a prerrogativa de criar tributos deixa de ser do monarca e passa a ser do parlamento). (COMPARATO, op. cit., p. 69 e 88).

${ }^{17}$ BONAVIDES, Paulo. Teoria do Estado. 7. ed. São Paulo: Malheiros, 2008. p. 41.
} 
entre os particulares e o poder, criando melhores condições para a proteção da liberdade e da segurança jurídica. ${ }^{19}$ Em outras palavras, a participação na produção do ordenamento jurídico condiciona o exercício do poder, que fica obrigado a levar em conta a posição dos particulares.

Não se pretende desenvolver aqui um estudo específico sobre o Estado de Direito, mas é necessário abordar a relação entre os direitos fundamentais e as limitações ao poder de tributar, bem como a questão da separação de poderes, com o escopo de se constatar, ao final, se a maior importância atribuída ao regulamento tributário na atualidade poderia reduzir a eficácia dos direitos fundamentais do contribuinte e das limitações ao poder de tributar, com o enfraquecimento das bases do Estado Democrático de Direito brasileiro.

\section{I.A.1 Direitos Fundamentais}

Como explanado acima, o Estado de Direito foi concebido e continua a existir na atualidade para proteger os direitos fundamentais, os quais encontram-se positivados na Constituição Federal brasileira no caput do artigo $5^{\circ}$, quais sejam: a vida, a liberdade, a igualdade, a segurança e a propriedade. Tais direitos são complementados por outros direitos e liberdades (e.g., de proteção contra a tortura e contra o tratamento desumano e degradante, de liberdade de imprensa, de liberdade de crença, de liberdade de ir e vir etc.).

Esses direitos fundamentais constituem-se, como explica Ingo Sarlet, direitos "de cunho 'negativo', uma vez que dirigidos a uma abstenção, e não a uma conduta positiva por parte dos poderes públicos, sendo, neste sentido, 'direitos de resistência ou de oposição perante o Estado'." 20 Tais direitos estabelecem uma zona fora do alcance da Administração Pública, uma zona de não intervenção.

Como explicado anteriormente, a proteção dos direitos fundamentais está vinculada ao próprio nascimento do Estado de Direito, sendo tais direitos, por essa razão,

\footnotetext{
${ }^{18}$ BONAVIDES, op. cit., p. 321.

${ }^{19}$ GARCÍA NOVOA, César. El principio de seguridad jurídica en materia tributaria. Madri: Marcial Pons, 2000. p. 27-29.

20 SARLET, Ingo Wofgang. A Eficácia dos Direitos Fundamentais: uma Teoria Geral dos Direitos Fundamentais na Perspectiva Constitucional. 10. ed. Porto Alegre: Livraria do Advogado Ed., 2009. p. 47.
} 
conhecidos como direitos de primeira dimensão ${ }^{21}$ ou de primeira geração ${ }^{22}$ pelos estudiosos dos direitos fundamentais e dos direitos humanos.

À medida que o Estado de Direito foi evoluindo, outros direitos fundamentais foram reconhecidos como os direitos sociais, econômicos e culturais (e.g., direito à saúde, direito à assistência social, direito de greve, direito de sindicalização etc.), os quais constituem não só limitações negativas ao poder, mas também exigências de prestações positivas. Tais direitos são conhecidos como de segunda dimensão ou geração, em adição aos direitos de primeira dimensão explicados acima. Posteriormente, foram reconhecidos outros direitos fundamentais adicionais, agora de natureza difusa (e.g., direito ao meio ambiente, à qualidade de vida etc.), conhecidos como direitos de terceira dimensão. Muitos desses direitos encontram-se positivados na Constituição Federal brasileira.

Registre-se ainda que o parágrafo $2^{\circ}$ do artigo $5^{\circ}$ da Constituição Federal estabelece que os direitos e garantias expressos na Carta Magna não excluem outros decorrentes do regime ou dos princípios constitucionais adotados, ou de tratados internacionais em que a República Federativa do Brasil seja parte. Esse princípio, como afirma Ingo Sarlet, ${ }^{23}$ proporciona uma abertura, uma amplitude relevante aos direitos fundamentais no Brasil, permitindo a construção jurisprudencial de direitos materialmente fundamentais não escritos, bem como de outros direitos fundamentais encontrados em outras partes do texto constitucional e nos tratados internacionais.

Apesar disso tudo, a grande questão que continua a existir é a necessidade de se proporcionar a eficácia plena dos direitos fundamentais, já que ainda acontecem, na prática, situações de violação ou de não implementação ${ }^{24}$ dos direitos fundamentais. ${ }^{25}$ Tais violações também continuam a ocorrer de forma frequente na área tributária.

\footnotetext{
${ }^{21}$ SARLET, Ingo Wolfgang. A Eficácia dos Direitos Fundamentais..., p. 45.

${ }^{22}$ BOBBIO, Noberto. A Era dos Direitos. Rio de Janeiro: Campus, 1992.

${ }^{23}$ SARLET, op. cit., p. 86.

${ }^{24}$ A Segunda Turma do Supremo Tribunal Federal julgou um caso em que não foi implementado o direito fundamental à educação infantil pelo Município de Santo André, quando foi reconhecido o direito de o Tribunal definir a política pública sobre esse tema, tendo em vista que se trata de uma diretriz constitucional, não implementada pelos poderes executivo e legislativo municipais. A omissão dos referidos poderes comprometia a eficácia e integridade do direito à educação infantil, assegurado pela Constituição Federal (Ag. Reg. no Recurso Extraordinário n. 436.996-6-SP; julgamento: 22.11.2005; DJU 03.02.2006). Daniel Sarmento aponta, com base em outros precedentes, a mudança de orientação do Supremo sobre o tema: antes normas dessa natureza eram consideradas programáticas; hoje, estão submetidas a uma intensa proteção judicial. (SARMENTO, Daniel. O Neoconstitucionalismo no Brasil: Riscos e Possibilidades. In: LEITE, George Salomão; SARLET, Ingo Wolfgang (coord). Direitos Fundamentais e Estado Constitucional.
} 


\section{I.A.2 Limitações ao Poder de Tributar}

Como forma de proteger o contribuinte da cobrança abusiva de tributos, são instituídas constitucionalmente limitações ao poder de tributar. Do mesmo modo que os direitos fundamentais de primeira dimensão, as limitações ao poder de tributar também constituem ordens negativas à Administração Tributária, fixando um núcleo jurídico fora do alcance do poder tributário.

As limitações constitucionais ao poder de tributar, as quais incluem o princípio da legalidade tributária, encontram-se positivadas na Constituição Federal atual na Seção II (“Das Limitações ao Poder de Tributar”) do Capítulo I ("Do Sistema Tributário Nacional”) do Título VI ("Da Tributação e do Orçamento”).

Como aponta Misabel Abreu Machado Derzi ${ }^{26}$ a natureza jurídica das limitações constitucionais ao poder de tributar é obscura, as quais se apresentam, em algumas ocasiões, como direitos em si mesmos e, em outras situações, como garantias de direitos fundamentais.

Independente disso, pode-se afirmar que os direitos fundamentais apenas têm condições de alcançar a sua eficácia plena em virtude da presença e da efetividade das

Estudos em Homenagem a J.J. Gomes Canotilho. São Paulo: Editora Revista dos Tribunais; Coimbra (Pt): Coimbra Editora, 2009. p. 30).

${ }^{25}$ Essa é uma das questões mais delicadas da atualidade. É sabido que há uma dificuldade prática de se impedir que direitos fundamentais sejam violados, ou seja, que tais direitos sejam plenamente eficazes e respeitados. Essa constatação é sabiamente feita por Norberto Bobbio ao afirmar que o campo dos direitos humanos "aparece, certamente, como aquele onde é maior a defasagem entre a posição da norma e sua efetiva aplicação" (BOBBIO, Norberto. A Era dos Direitos, p. 77). Essa observação também é notada por Gilmar Ferreira Mendes, especificamente quanto ao direito à liberdade, ao constatar que a "garantia dos direitos fundamentais enquanto direitos de defesa contra intervenção indevida do Estado e contra medidas legais restritivas dos direitos de liberdade não se afigura suficiente para assegurar o pleno exercício da liberdade" (MENDES, Gilmar Ferreira. Os Direitos Fundamentais e seus Múltiplos Significados na Ordem Constitucional. Repertório de Jurisprudência IOB, São Paulo, Caderno 1, n. 23/94, p. 335, $1^{\text {a }}$ Quinzena de dezembro de 2002.). Ricardo Lewandowski também afirma que as maiores dificuldades com relação aos direitos humanos "localizam-se precisamente no plano de sua realização concreta e no plano de sua exigibilidade" (LEWANDOWSKI, Enrique Ricardo. Proteção dos Direitos Humanos na Ordem Interna e Internacional. Rio de Janeiro: Forense, 1984. p. 66). Do mesmo modo, Ingo Sarlet afirma: “Aliás, ainda que no âmbito dos direitos de primeira dimensão o déficit de efetivação seja mais reduzido (pelo menos se considerarmos a possibilidade amplamente reconhecida de sua exigibilidade judicial), é preciso reconhecer que também nesta esfera longe nos encontramos, mesmo entre nós, de um patamar que se possa considerar tendencialmente satisfatório." (A Eficácia dos Direitos Fundamentais..., p. 55).

${ }^{26}$ BALEEIRO, Aliomar. Limitações Constitucionais ao Poder de Tributar. Anotado por Misabel de Abreu Machado Derzi. 7. ed. Rio de Janeiro: Forense, 1997, p. 67. 
limitações ao poder de tributar, razão pela qual essas limitações também devem ser consideradas cláusula pétrea.

Explica-se: a liberdade de crença apenas pode ser alcançada desde que não se exijam impostos sobre os templos de qualquer culto, razão pela qual o artigo 150, VI, "b" da Constituição Federal assegura a imunidade a tais templos. Do mesmo modo, a liberdade de pensamento apenas pode ser atingida desde que sejam livres de impostos os livros, jornais, periódicos e os insumos necessários para a sua produção (e.g., papel destinado à impressão); daí a imunidade prevista no artigo 150, VI, “d” da Carta Magna. E assim por diante.

Nesse passo, as limitações ao poder de tributar constituem uma faceta dos direitos fundamentais, sendo que, em alguns casos, elas assumem a feição de direitos em si mesmos e, em outros, de mecanismos de garantia dos referidos direitos fundamentais. Essa natureza jurídica híbrida já implicou a inclusão do princípio da legalidade tributária no mesmo dispositivo que tratava da declaração de direitos na Constituição Federal de 1.891 (artigo 72 , parágrafo 30 ). ${ }^{27}$

Como a sua violação em um caso concreto pode ser reclamada em juízo, as limitações ao poder de tributar constituem autênticos direitos subjetivos.

Apesar disso, existem muitas situações em que os direitos fundamentais do contribuinte continuam sendo desrespeitados na prática. Caso emblemático é o do imposto provisório sobre movimentações financeiras (IPMF), que foi incluído na Constituição Federal em 1993, via emenda, para ser exigido naquele mesmo ano. Nesse caso, o Supremo Tribunal Federal reconheceu a impossibilidade de cobrança do IPMF no ano de 1993 na Ação Direta de Inconstitucionalidade proposta pela Confederação Nacional dos Trabalhadores do Comércio - CNTC (ADI 939/DF; julgamento: 15.12.93; DJU 18.03.94). Mais do que reconhecer a violação ao princípio da anterioridade, a decisão judicial em questão reconheceu a estabilidade das limitações ao poder de tributar como forma de proteção dos direitos fundamentais do contribuinte, fora do alcance dos agentes estatais e

27 Ingo Wolfgang Sarlet considera as limitações ao poder de tributar "dispositivos formalmente constitucionais capazes de se caracterizarem como posições subjetivas e permanentes do indivíduo (isolada ou coletivamente)", fazendo inclusive referência ao julgamento do IPMF. (SARLET, Ingo Wolfgang. $A$ Eficácia dos Direitos Fundamentais..., p. 117). 
mesmo de alterações propostas por gerações futuras que venham a constituir a maioria no poder legislativo. ${ }^{28}$ Dada a intimidade com os direitos fundamentais do contribuinte, o Supremo expressamente reconheceu que o princípio da anterioridade e outras limitações ao poder de tributar constituem direitos individuais do contribuinte, objeto de cláusula pétrea na Constituição Federal.

Outro caso sobre direitos fundamentais e limitações ao poder de tributar que merece destaque é o julgamento da Medida Cautelar em Ação Direta de Inconstitucionalidade n. 1.075-1- DF pelo Supremo Tribunal Federal (julgamento: 17.06.98; DJU 24.11.2006). Nessa oportunidade, o Tribunal reconheceu que a imposição de multa fiscal de $300 \%$ constituía uma violação ao princípio do não-confisco ${ }^{29}$ e, ao mesmo tempo, aos direitos fundamentais ao mínimo existencial e à propriedade. Salientese que o Tribunal reconheceu que as limitações constitucionais ao poder de tributar constituem cláusulas abertas, do que decorreu o reconhecimento de que o princípio do nãoconfisco se aplica não somente aos impostos, como também a qualquer outra atividade estatal que implique a indevida apropriação de patrimônio do contribuinte, a exemplo da imposição da excessiva multa objeto da lei que teve a inconstitucionalidade reconhecida. Além disso, o Tribunal frisou a importância da história do constitucionalismo pátrio, lembrando que a Constituição Federal de 1934 continha um dispositivo expresso que determinava um teto máximo para aplicação das multas fiscais (que era de 10\%), bem como ressaltando que a ausência de um dispositivo escrito a esse respeito no atual texto constitucional é irrelevante.

Posteriormente, o Supremo Tribunal Federal esclareceu que a identificação do efeito confiscatório deve levar em consideração a totalidade da carga tributária do contribuinte, ou seja, deve ser realizada sob a luz do efeito cumulativo dos múltiplos tributos que incidem nos rendimentos e patrimônio do mesmo contribuinte, o que confirma

\footnotetext{
28 "Assim, constata-se, no fundo, que o reconhecimento de limitações de cunho material significa que, necessariamente, o conteúdo da Constituição não se encontra à disposição plena do legislador constitucional e, portanto, de uma maioria qualificada, sendo necessário, por um lado, impedir uma vinculação inexorável e definitiva das futuras gerações às concepções do Constituinte, e, por outro lado, garantir às Constituições a realização de seus fins." (SARLET, Ingo Wolfgang. Algumas Notas sobre o Poder de Reforma da Constituição e seus Limites Materiais no Brasil. In: TORRES, Heleno (coord.). Direito e Poder: nas Instituições e nos Valores do Público e do Privado Contemporâneos. Barueri, SP: Manole, 2005. p. 302).

${ }^{29}$ Sobre esse princípio, cf. HORVATH, Estevão. O Princípio do Não-Confisco no Direito Tributário. São Paulo: Dialética, 2002.
} 
a abertura e a densidade do princípio do não-confisco (Medida Cautelar na Ação Direta de Inconstitucionalidade n. 2010; julgamento: 30.09.1999; DJU 12.04.2002).

Antes de prosseguir, cabe registrar que a Constituição Federal contém outros direitos fundamentais e garantias do contribuinte em matéria tributária, além das limitações constitucionais ao poder de tributar. Com efeito, o próprio caput do artigo 150 da Constituição Federal deixa claro que as limitações ao poder de tributar não prejudicam outras garantias asseguradas ao contribuinte. Nesse sentido, o parágrafo primeiro do artigo 145 da Carta Magna, dentro da Seção que trata dos princípios gerais do sistema tributário nacional, expressamente determina que a Administração Tributária respeite os direitos individuais na identificação do patrimônio, rendimentos e as atividades econômicas do contribuinte, para fins de imprimir um caráter pessoal aos impostos e reconhecer a capacidade econômica do contribuinte. Além disso, outros direitos fundamentais constantes do texto constitucional também podem ter relevantes implicações na área tributária (e.g., o direito ao sigilo fiscal, o direito de restituição imediata e preferencial do ICMS pago no regime de substituição tributária, quando o fato gerador não ocorre; ao devido processo legal; etc.), bem como outros que decorrem da própria concepção de Estado de Direito, como o princípio de proteção da legítima confiança do contribuinte.

\section{I.A.3 Separação de Poderes}

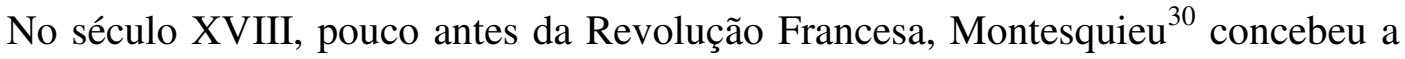
teoria da separação de poderes a partir da premissa de que o poder deve limitar o poder em virtude de que todo homem que detém o poder é levado a dele abusar. O homem vai até onde encontra limites. ${ }^{31}$

\section{Afirma Montesquieu:}

\footnotetext{
${ }^{30}$ MONTESQUIEU, Charles de Secondat, Baron de. O Espírito das Leis. Tradução: Cristina Murachco. 3. ed. São Paulo: Martins Fontes, 2005. p. 166. A obra original é de 1747.

${ }^{31}$ Antes dele, o tema de controle do poder já havia sido abordado por Jean-Jacques Rousseau sob o ângulo de que a sociedade apenas se obriga por meio de leis elaboradas por ela mesma (ROUSSEAU, Jean-Jacques. Do Contrato Social ou Princípios do Direito Político. Tradução: Pietro Nasseti. São Paulo: Editora Martin Claret, 2004). Do mesmo modo, John Locke considerava como supremo o poder legislativo e também previa os poderes executivo e federativo (LOCKE, John. Carta Acerca da Tolerância; Segundo Tratado sobre o Governo; Ensaio Acerca do Entendimento Humano. Tradução: Anoar Aiex e E. Jacy Monteiro. 3. ed. São Paulo: Abril Cultural, 1983. p. 86 e seguintes). Muito antes, Aristóteles já havia tratado em linhas gerais dos poderes deliberativo (assembleia), executivo e judiciário (ARISTÓTELES. A Política. Tradução: Roberto Leal Ferreira. 3. ed. São Paulo: Martins Fontes, 2006. p. 127 e seguintes).
} 
quando, na mesma pessoa ou no mesmo corpo de magistratura, o poder legislativo está reunido ao poder executivo, não existe liberdade; porque se pode temer que o monarca ou o mesmo senado crie leis tirânicas para executá-las tiranicamente. ${ }^{32}$

Tendo em vista a importância que a questão da tributação teve para a formação do Estado de Direito, Montesquieu também diz:

se o poder executivo estatuir [legislar] sobre a arrecadação do dinheiro público de outra forma que não a de seu consentimento, não haverá mais liberdade, porque ele se tornará legislativo no ponto mais importante da legislação.

A partir de premissas dessa natureza, e diante do sistema inglês, Montesquieu ${ }^{34}$ defendia a não concentração de poder em um mesmo homem, exigindo que fossem organizados órgãos compostos por diferentes indivíduos para exercer o poder legislativo, executivo e judiciário. ${ }^{35}$ De acordo com essa ideia, o poder legislativo estava incumbido da criação das leis, normas gerais em abstrato; o poder executivo era responsável pela aplicação das leis; e o poder judiciário tinha a função de pacificar conflitos. Para que os poderes não fossem exercidos de forma abusiva, Montesquieu pregava a instituição de um sistema de freios e contrapesos (checks and balances) permitindo que um poder tivesse alguma interferência no outro poder, criando uma situação de equilíbrio. ${ }^{36,37}$ Dentro desse sistema, cada poder deveria agir dentro das competências a ele atribuídas, não podendo invadir a competência de outro, nem delegar suas funções. ${ }^{38}$

\footnotetext{
${ }^{32}$ MONTESQUIEU, Charles de Secondat, Baron de. O Espírito das Leis. p. 168.

${ }^{33}$ MONTESQUIEU, op. cit., p. 176.

${ }^{34}$ MONTESQUIEU, op. cit., p. 168 e seguintes.

${ }^{35}$ A ideia subjacente a essa distribuição de poderes era equilibrar os poderes entre o Rei, a nobreza e o povo, a fim de que pudesse ser realizado um governo moderado.

${ }^{36}$ MONTESQUIEU, op. cit., p. 174 e seguintes.

$37 \mathrm{Na}$ Constituição Federal brasileira, por exemplo, os seguintes mecanismos são exemplos de freios e contrapesos: o poder de veto do presidente da república na edição de leis; a atribuição do Senado de aprovar previamente a escolha de ministros do Supremo Tribunal Federal; a competência do Senado de julgar o presidente nos crimes de responsabilidade; etc.

38 "É preciso, todavia, não olvidar que o apego ao princípio da indelegabilidade tinha um fundamento político bem mais forte do que sua justificação jurídica. Era ele concebido como uma garantia necessária para resguardar a "separação de poderes" contra usurpações e fraquezas. Na verdade, a insistência nesse princípio, que veio até nossos dias, era motivada, sobretudo, pela preocupação de defender o Legislativo contra a voracidade do Executivo. Primeiro, para proteger a representação nacional contra os monarcas, impedindo-os de, por coação ou corrupção, reconstituir o absolutismo por meio de delegações. Depois, para
} 
A constituição ficaria incumbida de estabelecer as competências de cada poder. Ela fixaria as raias dentro das quais cada poder deveria cumprir o seu papel, como modo de buscar a proteção contra a arbitrariedade dos governantes.

Tendo em vista que, no Estado de Direito, o poder é uno e indivisível e emana do povo, o mais apropriado é falar em separação de "funções", ${ }^{9}$ e não em separação de poderes, como originalmente concebido.

Ademais, e como já advertia Hans Kelsen ${ }^{40}$ no século XX, o mais adequado é falar em "distribuição" de funções e não na separação delas, já que a completa separação não existe e o foco do princípio da tripartição de poderes é evitar a concentração de poder em um só órgão. Kelsen também afirmava que o Poder Legislativo tem, na realidade, uma prioridade, uma posição favorecida na edição de normas gerais, o que não exclui a possibilidade de o Poder Executivo editar normas de mesma estatura.

No início do século XX, Jellinek afirmava ser ingênuo acreditar na coincidência de toda a atividade normativa no Poder Legislativo, o que não solucionava diversos problemas teóricos e práticos da Teoria do Estado. ${ }^{41}$ Antes, James Madison, ${ }^{42}$ ao defender a separação de poderes como forma de combate do uso tirânico do poder, reconhecia que tal separação não existia de forma plena nas constituições dos vários estados norteamericanos, mas deveria ser buscada.

Desse modo, muito embora a teoria de Montesquieu pregasse a independência dos poderes legislativo, executivo e judiciário, estudiosos da Teoria do Estado já afirmavam que a separação de poderes não existia de forma plena, sendo um ideal.

À medida que o Estado de Direito vai desenvolvendo, diante dos compromissos sociais assumidos perante o povo e em virtude da crescente complexidade das atividades econômicas, vai ficando cada vez mais evidente e intensa a participação normativa do

proteger ainda o Parlamento, mas contra o Executivo de origem popular, não menos ambicioso e devorador." (FERREIRA FILHO, Manoel Gonçalves. Do Processo Legislativo. 6. ed. São Paulo: Saraiva, 2007. p. 116).

39 JELLINEK, G. Teoria General del Estado. Tradução: Fernando de los Ríos Urruti. Granada: Editorial Comares, 2000. p. 599.

${ }^{40}$ KELSEN, H. Teoria Geral do Direito e do Estado. 2. ed. São Paulo: Martins Fontes, 1992. p. 266 e 274.

${ }^{41}$ JELLINEK, op. cit., p. 601. 
Poder Executivo. ${ }^{43}$ Esse cenário é tão marcante que deixa de refletir o bom senso afirmar que a organização atual do Estado reflete a doutrina clássica da separação de poderes de Montesquieu. $^{44,45}$

O Poder Legislativo vai passando a traçar as linhas gerais de como uma matéria deve ser tratada, e o Poder Executivo vai passando a regular tal matéria de forma cada vez mais detalhada sob a luz dos seus aspectos técnicos e práticos, que vão se tornando cada vez mais importantes. A atividade do Poder Legislativo vai se limitando, assim, às grandes escolhas políticas, atribuindo-se ao Executivo o direito de regular os demais aspectos da matéria relevante, sobretudo os técnicos.

É exatamente nesse cenário que a lei propriamente dita vai paulatinamente perdendo a sua força com a atribuição de uma importância maior ao regulamento.

Para tratar a questão dos limites entre a lei e o regulamento no presente trabalho, é importante abordar-se previamente o Direito como um sistema de normas, o que é feito a seguir.

\section{I.B Direito como Sistema}

O Direito é um sistema, uma vez que constitui um conjunto composto por normas que se relacionam entre si de forma ordenada ${ }^{46}$ e que estão ligadas ${ }^{47}$ por meio de um bloco de valores e direitos fundamentais. Referidos valores e direitos fundamentais constituem o ponto de ordem e de unidade do sistema.

\footnotetext{
${ }^{42}$ HAMILTON, Alexander; MADISON, James; e JAY, John. O Federalista. Tradução: Heitor Almeida Herrera. Brasília: Editora Universidade de Brasília, 1984. p. 393 e seguintes.

43 "Na verdade, o advento e o crescimento do Estado-gestor tornou muito mais complexa a legislação como fonte de direito. Se no início ela pôde se restringir à produção de leis, hoje abarca um rol enorme de atos, como resoluções, regimentos, instruções normativas, circulares, ordens de serviço etc. que, em tese (liberal) deveriam estar subordinadas às leis enquanto expressão da vontade do povo, mas que, na prática, implodem a chamada estrutura hierárquica das fontes." (FERRAZ JR., Tércio Sampaio. Introdução ao Estudo do Direito. São Paulo: Atlas, 1991. p. 212.)

${ }^{44}$ FERREIRA FILHO, Manoel Gonçalves. Aspectos do Direito Constitucional Contemporâneo. 2. ed. São Paulo: Saraiva, 2009, p. 96.

${ }^{45}$ José Afonso da Silva indica que, diante da realidade atual, se prefere falar em colaboração de poderes, em vez de divisão de poderes. (SILVA, José Afonso da. Curso de Direito Constitucional Positivo. 28. ed, revista e atualizada. São Paulo: Malheiros, 2007. p. 109).

${ }^{46}$ BOBBIO, Norberto. Teoria do Ordenamento Jurídico. 10. ed. Brasília: Editora UnB, 1999. p. 71.
} 
O referido bloco de valores e direitos fundamentais faz com que o Direito seja um sistema carregado com um conteúdo diferenciado, e não um sistema puro, isolado da moral, como defendido pelos positivistas. Desse modo, uma lei não é observada em virtude do mero fato de ela ser uma lei, ${ }^{48}$ mas sim em razão de o seu conteúdo refletir ou estar em consonância com os valores e direitos fundamentais perseguidos e protegidos pelo Direito. Nesse passo, em um ambiente de inflação legislativa, não se aceita qualquer mudança jurídica decorrente de uma alteração legislativa com indiferença; investiga-se o conteúdo da nova lei e a sua relação de pertinência com o sistema (i.e., validade formal e material).

Essa ideia de que o Direito é um sistema carregado com valores e direitos fundamentais, que lhe dá unidade, reflete a chamada virada kantiana, ${ }^{49,50}$ que é defendida mais recentemente por alguns autores no Brasil, como Ricardo Lobo Torres na área tributária. ${ }^{51}$ Tal visão permite uma conexão entre as normas jurídicas e as razões subjacentes que desencadearam o advento do Estado de Direito.

A visão positivista e mais tradicional é que o Direito é um sistema puro, que não sofre influência de elementos externos, como valores ou princípios que não são objeto de normas positivadas (de modo que não seria cabível estudar as razões históricas de um princípio ou os efeitos de uma lei na comunidade). Nessa visão, o ponto de apoio e união do sistema não são valores e direitos fundamentais, mas sim a norma hipotética fundamental (ubi consistam), que se encontra fora do sistema e que serve de razão desse, não havendo necessidade de buscar outras bases. ${ }^{52}, 53$

\footnotetext{
${ }^{47}$ Essa conectividade entre as normas é que dá o mínimo de racionalidade necessária para o Direito ser considerado como um sistema (CARVALHO, Paulo de Barros. Direito Tributário - Fundamentos Jurídicos da Incidência. 2. ed. São Paulo: Saraiva, 1999. p. 39).

${ }^{48}$ Como aponta Tércio Sampaio Ferraz Jr. (sem tratar especificamente do Direito Tributário), a positivação implicou a institucionalização da mutabilidade do Direito. (FERRAZ Jr., Tércio Sampaio. Introdução ao Estudo do Direito..., p. 168).

${ }^{49}$ Como exemplo, ver DWORKIN, Ronald. Tradução: Jefferson Luiz Camargo. O Império do Direito. São Paulo: Martins Fontes, 2003.

${ }^{50}$ Neil MacCormick também defende que a argumentação jurídica de uma decisão, além de incluir normas positivadas e precedentes, deve levar em conta princípios e valores subjacentes, de tal sorte que a argumentação interpretativa é em parte uma argumentação moral (MACCORMICK, Neil. Institutions of Law: an Essay in Legal Theory. Oxford: Oxford University Press, 2007. p. 260).

${ }^{51}$ TORRES, Ricardo Lobo. Tratado de Direito Constitucional Financeiro e Tributário.... p. 56-58.

${ }^{52}$ BOBBIO, Norberto. Teoria do Ordenamento..., p. 58 e seguintes.

${ }^{53}$ KELSEN, Hans. Teoria Pura do Direito. Tradução: João Baptista Machado. 3. ed. São Paulo: Martins Fontes, 1991. p. 220.
} 
Independente do fundamento de unidade do Direito, o ordenamento jurídico acaba por se desenvolver de forma desordenada, sem a completude e coerência desejadas, não havendo soluções para todas as imagináveis situações fáticas, que se renovam frequentemente. A complexidade e a evolução da vida econômica agravam os problemas do Direito, que tenta acompanhar esse desenvolvimento. Assim, existem, naturalmente, antinomias, lacunas e situações que devem ser resolvidas por meio de ponderação.

Logo, o Direito não constitui um sistema perfeito, completo e coerente por si só, podendo haver lacunas e colisões entre princípios, conflitos entre regras, e conflitos entre princípios e regras, cabendo ao intérprete a tarefa de atribuir unidade e coerência ao sistema. Essa tarefa é desempenhada diariamente em inúmeras situações do operador do Direito, sendo relevante salientar que cada intérprete pode dar uma solução (idêntica, semelhante ou diferente) diante do mesmo conjunto de normas e fatos, sendo que a interpretação que deverá prevalecer será aquela melhor articulada, com base em argumentos fundados no ordenamento jurídico como um todo e sob a luz dos direitos fundamentais e valores desse sistema. ${ }^{54}$ Nessa atividade, o intérprete parte do texto escrito para construir a norma, debruçando-se sobre os aspectos sintáticos, semânticos e pragmáticos do texto para criar a norma, conforme a divisão proposta pela Semiótica. ${ }^{55}$

Por essa razão é que Paulo de Barros Carvalho ${ }^{56}$ afirma que o direito é fechado sintaticamente, mas aberto em termos semânticos e pragmáticos.

Ainda a respeito da ideia do Direito como sistema, cumpre registrar que o direito tributário não é autônomo, ${ }^{57,58}$ independente do Direito e de outros ramos desse. O direito tributário está inserido no ordenamento jurídico com ele se relacionando e se integrando.

\footnotetext{
${ }^{54}$ Por esse motivo, Eros Roberto Grau afirma que o texto normativo é alográfico, demandando completude pelo intérprete. (GRAU, Eros Roberto. Ensaio e Discurso sobre a Interpretação/Aplicação do Direito. 3. ed. São Paulo: Malheiros, 2005. p. 78-79).

${ }^{55}$ FERRAZ JR., Tércio Sampaio. Introdução ao Estudo..., p. 118 e seguintes.

${ }^{56}$ CARVALHO, Paulo Roberto. Direito Tributário - Fundamentos, p. 103.

57 A autonomia do Direito Tributário - ainda que não absoluta - era defendida por Louis Trotabas. (vide TROTABAS, Louis. Ensaio sobre o Direito Fiscal. Tradução: Guilherme Augusto dos Anjos. Revista de Direito Administrativo, Rio de Janeiro, Fundação Getúlio Vargas, v. 26, p. 34-59, out-dez de 1951.). Em oposição, François Geny defendia a colaboração entre Direito Tributário e Direito Civil e Comercial. (vide GENY, François. O Particularismo do Direito Fiscal. Tradução: Guilherme Augusto dos Anjos. Revista de Direito Administrativo, Rio de Janeiro, Fundação Getúlio Vargas, v. 20, p. 6-31, abr-jun de 1950.). Heleno Torres reporta o debate entre as referidas duas correntes. (TORRES, Heleno. Contribuições da Doutrina Italiana para a Formação do Direito Tributário Brasileiro. In: SCHOUERI, Luís Eduardo (coord.) Direito
} 
Tendo explorado as noções de Estado Democrático de Direito, do Direito como um sistema e do ônus do intérprete de dar unidade e coerência ao sistema, cabe abordar então as fontes do sistema tributário brasileiro propriamente dito, como forma de aproximação da questão da tensão entre a lei e o regulamento na seara tributária.

\section{I.C Fontes do Direito Tributário. Constituição, Lei e Regulamento e a Competência Tributária.}

Como bem salienta Tércio Sampaio Ferraz Jr., a teoria das fontes está relacionada com a questão da identificação do que seja Direito na atualidade. ${ }^{59}$

A pedra angular do sistema tributário brasileiro se encontra no bloco de direitos fundamentais e valores adotados pelo povo brasileiro na concepção da República Federativa do Brasil como um Estado de Direito. Tais direitos fundamentais compreendem o direito à vida, à liberdade, à igualdade, à segurança e à propriedade. ${ }^{60}$ Os direitos fundamentais incluem o direito à dignidade da pessoa humana, ao mínimo existencial, à segurança jurídica, à igualdade, etc. O preâmbulo da Constituição brasileira faz referência a alguns desses direitos fundamentais ou de seus fundamentos, como a liberdade, a igualdade, a justiça e a solidariedade.

É essencial considerar o bloco de direitos fundamentais e valores referido acima como fonte do sistema tributário brasileiro, visto que tal fonte é a última barreira diante da Administração Tributária, vinculando-a e protegendo o contribuinte. Ou seja, muito embora seja possível a utilização de todas as demais fontes do Direito para alteração do ordenamento jurídico, incluindo a introdução de emendas à constituição, o bloco de

Tributário - Homenagem a Alcides Jorge Costa. Volume II. São Paulo: Quartier Latin, inverno de 2003. p. 1148-1167.). No Brasil, Paulo de Barros Carvalho critica a autonomia do Direito Tributário atribuindo a essa discussão o apropriado adjetivo de "falsa" (vide CARVALHO, Paulo de Barros. Curso de Direito Tributário... p. 13-17.). Geraldo Ataliba critica aqueles que defendem de forma irresponsável a autonomia do Direito Tributário no Brasil. Vide o prefácio à primeira edição da seguinte obra: DERZI, Misabel de Abreu Machado. Direito Tributário, direito penal e tipo. 2. ed. São Paulo: Editora Revista dos Tribunais, 2007. p. 9 e seguintes.

${ }^{58}$ A autonomia que existe do Direito Tributário é apenas para fins didáticos, ou seja, para estudo como um ramo do Direito.

${ }^{59}$ FERRAZ Jr., Tércio Sampaio. Introdução..., p. 202.

${ }^{60}$ Consistente com a ideia de que os valores compõem o sistema tributário, Ricardo Lobo Torres afirma que a decisão a respeito da tributação é sempre valorativa. (TORRES, Ricardo Lobo. Tratado de Direito Constitucional..., p. 57). 
direitos fundamentais inerente ao Estado de Direito brasileiro (os quais são considerados cláusulas pétreas da Constituição) é intocável, cabendo ao Poder Judiciário protegê-lo, o que implica a possibilidade de o Judiciário declarar como inconstitucional até mesmo uma emenda à Constituição Federal. ${ }^{61,62}$

Nesse passo, pode-se afirmar que o conceito de fonte do direito ${ }^{63}$ no sentido de órgão credenciado a produzir normas ou da própria atividade de produção de normas jurídicas ou de linguagem normativa (em contraste com as normas propriamente ditas), observando-se o processo fixado no ordenamento jurídico, não é suficiente, ${ }^{64}$ devendo-se lembrar das limitações impostas pelos direitos fundamentais e valores, que submetem o poder ao direito, e não o contrário. Ou seja, o órgão credenciado a produzir normas por uma regra de competência não está livre para deliberar sobre a matéria atribuída de qualquer maneira, devendo observar e respeitar os direitos fundamentais e valores do sistema jurídico.

Dito isso, pode-se classificar as demais fontes positivas (instrumentos introdutórios de normas) do Direito entre instrumentos primários e secundários. ${ }^{65}$ Os instrumentos

\footnotetext{
61 Foi o que aconteceu no caso envolvendo a cobrança do imposto provisório sobre movimentações financeiras em 1993, no mesmo ano em que foi editada a emenda constitucional que o instituiu (a Emenda Constitucional n. 3, de 01.03.1993). Nos termos da referida emenda constitucional, o IPMF poderia ser cobrado ainda em 1993 e constituiria uma exceção ao princípio da anterioridade (princípio da não surpresa, que também protege a segurança jurídica). Apesar de haver outras exceções ao princípio constitucional da anterioridade na própria Constituição Federal (imposto de importação, de exportação, de produtos industrializados, imposto sobre operações de crédito, câmbio e seguros ou relativa a títulos e valores mobiliários, e ainda o imposto extraordinário na iminência ou em caso de guerra externa), o Supremo Tribunal Federal reconheceu corretamente a impossibilidade de cobrança do IPMF no ano de 1993, diante de Ação Direta de Inconstitucionalidade proposta pela Confederação Nacional dos Trabalhadores do Comércio - CNTC (ADI 939/DF; DJU 18.03.94). Mais do que reconhecer a violação ao princípio da anterioridade, a decisão judicial em questão reconheceu a estabilidade dos direitos fundamentais do contribuinte.

${ }^{62}$ Vale transcrever as palavras de Paulo Otero sobre a necessidade de considerar os direitos fundamentais como uma fonte de Direito Administrativo, plenamente aplicável ao Direito Tributário no Brasil: "Esta é, em última análise, a única postura compatível com um Estado de Direito material ou Estado de juridicidade que se assume como sendo um Estado de Direito democrático, mostrando que a discussão em torno das fontes de Direito Administrativo nunca é inocente face ao entendimento que se perfilhe sobre as relações entre o Poder e o Direito ou, mais concretamente, entre uma concepção que defenda um Poder limitado pelo Direito ou, em alternativa, um Direito dominado pelo Poder." (OTERO, Paulo. Legalidade e Administração Pública. O Sentido da Vinculação Administrativa à Juridicidade. Coimbra: Edições Almedina S.A., março de 2007. p. 375).

${ }^{63}$ CARVALHO, Paulo de Barros. Curso de Direito Tributário..., p. 49.

${ }^{64} \mathrm{O}$ direito não se esgota em atos jurídicos provenientes de fontes formais, como afirma OTERO, op. cit., p. 24.

${ }^{65}$ CARVALHO, op. cit., p. 57 e seguintes. Paulo de Barros Carvalho explica de forma adequada que considerar como fontes de direito as normas positivas levaria a uma circularidade do direito, razão pela qual as verdadeiras fontes são os órgãos credenciados pelo ordenamento para produzi-las e também o próprio processo de produção dessas normas (motivo pelo qual esse autor também não aceita a divisão entre fontes formais e fontes materiais).
} 
primários têm a capacidade de inovar a ordem jurídica, e os instrumentos secundários são aqueles que não têm tal capacidade, cabendo-lhes apenas regulamentar o subsistema composto pelos instrumentos primários, referido como "lei" em sentido amplo por Paulo de Barros Carvalho. Esse critério permite diferenciar os instrumentos primários dos secundários, bem como estabelecer uma relação de hierarquia entre tais instrumentos, de modo que os últimos são hierarquicamente inferiores aos primeiros. ${ }^{66}$

Constituem os instrumentos primários: (i) a Constituição Federal, com realce aos princípios constitucionais tributários e à atribuição de competência legislativa à União Federal, aos Estados, aos Municípios e ao Distrito Federal para instituir tributos; (ii) a lei complementar, aprovada pela maioria absoluta dos membros do Congresso Nacional, com a função de estabelecer normas gerais em matéria de legislação tributária, de dispor sobre conflitos de competência em matéria tributária e de regular as limitações constitucionais ao poder de tributar; (iii) a lei ordinária, como veículo de excelência de instituição da regramatriz de incidência tributária (com a definição de todos os aspectos dessa, quais sejam: o material, espacial, temporal, pessoal e quantitativo), e como veículo de introdução de obrigações acessórias; (iv) as medidas provisórias, com força de lei e de competência do Presidente da República, que também tratam de matéria tributária, como admitido pelo Supremo Tribunal Federal; (v) as leis delegadas, de competência do Presidente da República, mediante delegação do Congresso Nacional, raras no direito tributário; (vi) os decretos legislativos, que introduzem no ordenamento jurídico nacional tratados e convenções internacionais que tratem de matéria tributária (exclusivamente ou no bojo de um tratado mais amplo como, os tratados de transporte aéreo ou marítimo); e (vii) as resoluções, de competência de ambas as casas do Congresso Nacional, as quais são aprovadas por maioria simples dos membros do Senado ou da Câmara de Deputados, que tratam, por exemplo, das alíquotas interestaduais no âmbito do imposto sobre circulação de mercadorias e serviços (o "ICMS"). ${ }^{67}$

Já os instrumentos secundários são os seguintes: (i) os decretos regulamentares, de competência dos chefes dos poderes executivos de cada ente público interno, com o escopo de regulamentar a legislação tributária; (ii) as instruções ministeriais, normas de

\footnotetext{
${ }^{66}$ Daí a importância de se admitir a estrutura escalonada do Direito de Hans Kelsen (pirâmide). (KELSEN, Teoria Pura..., p. 240.)

${ }^{67}$ Vide incisos IV e V do parágrafo $2^{\circ}$ do artigo 155 da Constituição Federal.
} 
competência dos Ministros de Estado com o escopo de promover as leis, decretos e regulamentos que tratem da matéria sob seus cuidados; (iii) as circulares, que não têm o caráter geral como as instruções ministeriais, objetivando alcançar um setor específico, uma função administrativa delimitada; (iv) as portarias, que podem ser editadas pelos superiores da Administração Pública direta ou indireta, consubstanciando regras gerais ou individuais, para serem observadas por seus funcionários; (v) as ordens de serviço, autorizações ou estipulações concretas, com o alcance e objetivo bem delimitados; (vi) os demais atos normativos estabelecidos pelo fisco, que correspondem a outros atos veiculados por órgãos da Administração Pública com a pretensão de vincular e uniformizar a interpretação dos funcionários públicos, como os pareceres normativos, as soluções de divergência em respostas a consulta, as decisões emitidas pelos órgãos julgadores do Poder Administrativo; (vii) os convênios entre União, Estados, Municípios e Distrito Federal; (viii) as práticas reiteradas do fisco, ainda que sem a edição de um ato formal de caráter geral; ${ }^{68}$ e (xi) a jurisprudência pacífica dos Tribunais, sobretudo a do Supremo Tribunal Federal, especialmente quando presente uma súmula vinculante editada conforme o artigo 103-A da Constituição Federal. ${ }^{69}$

Feitas essas observações gerais acerca das fontes do Direito Tributário, passa-se a tratar especificamente da Constituição, da lei e do regulamento, tendo em vista que a questão sob análise nesse trabalho envolverá a relação entre essas normas.

Como salientado acima, a Constituição Federal estabelece os princípios constitucionais tributários e atribui competência legislativa à União Federal, aos Estados, aos Municípios e ao Distrito Federal para instituir tributos.

A competência tributária constitui a habilitação de um ente político para instituir e cobrar tributos, de acordo com a norma-padrão de incidência do tributo fixada na Constituição Federal. Sem dúvida, como apenas a lei pode instituir tributos, a autorização para instituir tributos somente pode ser atribuída às pessoas políticas, dotadas de poder

\footnotetext{
${ }^{68}$ Aliomar Baleeiro adotava a interpretação ampla do artigo 100, III do Código Tributário Nacional, com a inclusão do maior número de fontes possível, a fim de proteger o contribuinte contra a mudança da interpretação da legislação tributária pelo fisco. BALEEIRO, Aliomar. Direito Tributário Brasileiro. Atualizadora: Misabel Abreu Machado Derzi.11. ed. Rio de Janeiro: Editora Forense, 2005. p. 648-649.

69 As palavras de Aliomar Baleeiro também são muito importantes nesse ponto ao criticar o Código Tributário Nacional, que não incluiu, entre as normas complementares da legislação tributária, a jurisprudência pacífica dos Tribunais. BALEEIRO, op. cit., p. 652.
} 
legislativo. A competência tributária, note-se bem, não cria tributos, mas apenas faculta a sua criação dentro do arquétipo constitucional. ${ }^{70}$ Trata-se de uma norma estrutural, que dispõe acerca da produção de outras normas. ${ }^{71}$

Como explica Roque Carrazza, a competência tributária atribuída pela Constituição Federal às pessoas políticas acima indicadas é conferida, em última instância, pelo povo, do qual todo o poder emana. ${ }^{72}$ Ainda que a participação do povo nesse ato de conferência de competência seja uma ficção em um país de dimensão continental como o Brasil, fato é que a competência tributária apenas pode ser exercida com a observação das limitações constitucionais ao poder de tributar e de todos os outros princípios contidos da Carta Magna. Logo, a competência tributária é qualificada e não pode ser exercida de qualquer modo com, por exemplo, o desrespeito à igualdade por meio da criação de privilégios odiosos. Fora tais limitações, a competência tributária é plena, nos termos do artigo $6^{\circ}$ do Código Tributário Nacional.

A lei ordinária, por sua vez, é a norma típica utilizada para a instituição de tributos por uma pessoa política com base na competência tributária que lhe foi outorgada pela Constituição Federal. Sem competência tributária conferida pela Constituição Federal, não pode a pessoa política instituir tributo por meio de lei. A obrigação de utilização desse veículo normativo decorre do princípio da legalidade tributária, estudado abaixo em item próprio com mais vagar.

Com base na mesma competência tributária constitucional e na medida em que tenha instituído um tributo, a lei ordinária de uma mesma pessoa política também pode ser utilizada para a instituição de obrigações acessórias ou deveres instrumentais.

Do mesmo modo, apenas pode regulamentar a cobrança de um tributo a pessoa política que detém a competência tributária para instituí-lo e desde que, observe-se bem, tenha previamente exercido a faculdade de criação desse tributo com base em lei. Discute-

\footnotetext{
${ }^{70}$ Muito embora a Constituição Federal tenha atribuído à União Federal a competência para instituir o imposto sobre grandes fortunas (artigo 153, VII), o referido imposto não chegou a ser instituído.

71 São características da competência tributária: a privatividade, a indelegabilidade, a incaducabilidade, a inalterabilidade, a irrenunciabilidade e a facultatividade. O Código Tributário Nacional trata da competência tributária em seus artigos $6^{\circ}$ a $8^{\circ}$.

${ }^{72}$ CARAZZA, R oque. Princípios Constitucionais Tributários e Competência Tributária. São Paulo: Editora Revista dos Tribunais, 1986. p. 32.
} 
se se a instituição de deveres instrumentais está condicionada ou não à edição de uma lei específica ou se a lei instituidora do tributo seria suficiente, o que é comentado abaixo. De toda maneira, apenas a pessoa política competente que instituiu um tributo pode instituir os deveres instrumentais respectivos.

Do acima exposto, verifica-se que todo o arcabouço jurídico que governa um determinado tributo orbita em torno da competência tributária constitucional. É ela que define o arquétipo do tributo e faculta a sua instituição e regulamentação por uma determinada pessoa política por meio dos instrumentos normativos comentados acima.

Muito embora a lei ordinária seja o veículo adequado para a instituição da regramatriz de incidência tributária em sua inteireza pela pessoa política competente, fato é que, em alguns casos, o Poder Judiciário admitiu como legítima a interação entre a lei e uma norma infralegal, de tal modo que fosse atribuída uma relevância marcante à regulamentação editada. O já referido caso SAT é um exemplo. Existem casos também em que o Poder Judiciário admitiu a instituição de obrigações acessórias sem que exista lei específica sobre as mesmas, apenas com base na lei instituidora do tributo. Existem outras situações ainda onde a lei ordinária faz importantes reenvios à regulamentação, que passa a tratar de um tema sensível ao contribuinte.

Disso tudo decorre que a importância do regulamento e de outros atos infralegais no Direito Tributário passou a ser maior na atualidade.

Diante dessa constatação, que será discutida ao longo deste capítulo, o intérprete deve, na construção da regra-matriz de incidência tributária, no exame das obrigações acessórias e na análise da legislação tributária em geral, se voltar não só à lei ordinária, mas também ao regulamento e a outros atos infralegais; tudo sob a luz da lei complementar e da Constituição Federal. O interessante é que o intérprete deve ter consciência da maior relevância da regulamentação, devendo ter um cuidado maior no exame dessa. ${ }^{73}$

\footnotetext{
${ }^{73}$ No passado, Geraldo Ataliba defendia que ao regulamento não se deveria atribuir matérias relevantes: "Ao regulamento incumbe prescrever onde poderá ser satisfeita a exigência legal, qual o funcionário que receberá os documentos respectivos, quem os examinará, quais os papéis a serem preenchidos e de que forma, etc.". Mais adiante, o autor reconhece a atividade interpretativa implícita à elaboração do regulamento, mas não podia antever, naquela oportunidade, como a vida econômica e o sistema tributário se tornariam complexos e como a atividade regulamentar ficaria, consequentemente, mais importante. Vide ATALIBA, Geraldo.
} 
Com a ideia exposta acima de que cumpre ao intérprete analisar, com o cuidado devido, a lei ordinária e o regulamento ou outros atos infralegais, e tendo ainda em vista que o presente trabalho objetiva tratar da participação do contribuinte na edição de tais atos infralegais, abordam-se, abaixo, os princípios da legalidade tributária e da legalidade genérica.

\section{I.D O Princípio da Legalidade Tributária}

\section{I.D.1 Valores Protegidos pela Legalidade Tributária: Liberdade e Segurança Jurídica}

Para tratar do princípio da legalidade tributária, é importante ter em mente que esse princípio busca garantir a liberdade e a segurança jurídica.

Sem adentrar nos aspectos históricos do princípio da legalidade tributária, que demonstram a conquista que esse princípio representa como meio de proteção da liberdade ${ }^{74}$ pode-se afirmar que a lei - norma geral e abstrata, aplicável a pessoas que se encontrem em situação equivalente - é editada em processo específico conduzido pelo Poder Legislativo, cujos membros são eleitos pelo povo. A participação do povo no processo legislativo torna a lei expressão de liberdade e justifica um primado da lei sobre os demais atos estatais.

Como o Poder Legislativo é composto por representantes eleitos pelo povo, há a ideia de que a tributação, ou o aumento dela, é consentida pelo povo. ${ }^{75}$ Ou seja, a tributação é legitimada pelo direito de participar, pelo direito de votar no Estado de Direito, ${ }^{76}$ não havendo uma situação de tirania do Estado. É a aplicação das ideias de

Decreto Regulamentar no Sistema Brasileiro. Revista de Direito Administrativo, Rio de Janeiro, FGV, v. 97, p. 31, jul./set. 1969.

${ }_{74}$ A esse respeito, vide ROTHMANN, Gerd W. O Princípio da Legalidade Tributária. Revista de Direito Mercantil, Industrial, Econômico e Financeiro. São Paulo, Editora Revista dos Tribunais, n. 8, p. 65, 1972; e UCKMAR, Victor. Princípios Comuns do Direito Constitucional Tributário. Tradução: Marco Aurélio Greco. São Paulo: Editora Revista dos Tribunais, 1976. p. 9 e seguintes.

${ }^{75}$ TORRES, Ricardo Lobo. Tratado... p. 92; TORRES, Ricardo Lobo. A Ideia de Liberdade ..., p. 112.

${ }^{76}$ SCHOUERI, Luís Eduardo. Normas Tributárias Indutoras e Intervenção Econômica. Rio de Janeiro: Editora Forense, 2005. p. 232 e seguintes. 
sacrifício coletivamente consentido, de autotributação $^{77}$ e de no taxation without representation.

A ideia de consentimento à tributação constitui, evidentemente, uma autêntica ficção em um país com as dimensões do Brasil na atualidade, tendo em vista que não há um "de acordo" com a lei tributária por parte dos distintos grupos de interesses que compõem o povo e que elegem, por maioria, os representantes no Poder Legislativo (e, ainda que existisse esse "de acordo", o tributo não seria cobrado de forma coercitiva com base em lei, porque haveria consenso com relação ao seu pagamento). Bem por isso, o consentimento à tributação constitui, na realidade, a ideia de que o povo está "de acordo" com a instituição e majoração da tributação por meio de lei votada por membros do Poder Legislativo, desde que os direitos fundamentais do contribuinte sejam respeitados.

O raciocínio acima constitui o reconhecimento de que o poder emana do povo de forma uniforme apenas e tão somente quando se tratam dos limites à tributação impostos pelos direitos fundamentais. Portanto, o consentimento do povo não está ligado diretamente à tributação, mas sim ao ordenamento jurídico, à ideia de viver em um Estado organizado que protege a liberdade, entre outros direitos fundamentais. ${ }^{78}$

Com o consentimento do povo concretizado em lei formal, o tributo deixa de caracterizar uma relação de poder irresistível e passa a constituir uma relação jurídica, como expressão da liberdade.

Ao Executivo caberia apenas e tão somente cobrar o tributo nos termos estabelecidos em lei, não podendo ele ter qualquer participação na atividade legiferante, que não lhe diz teoricamente respeito, sob risco de se concentrar no mesmo Poder os poderes de instituição e cobrança dos tributos, com sérios riscos à liberdade. Assim é que a separação de poderes, ou melhor, a distribuição de funções no Estado de Direito (entre

\footnotetext{
77 XAVIER, Alberto. Os Princípios da Legalidade e da Tipicidade da Tributação. São Paulo: Editora Revista dos Tribunais, 1978. p. 5 e seguintes.

${ }^{78} \mathrm{O}$ Estado não é uma unidade social constituída por um interesse comum apto a expressar o consentimento à tributação, sendo mais adequada a ideia de que o Estado constitui a ordem jurídica, mas não pura, isolada da ética e de valores, sob risco de se admitir um Estado ditatorial em razão desse estar positivado. (KELSEN, Hans. Teoria Geral do Direito e do Estado. p. 186-187). Jellinek já havia reconhecido a existência de uma obrigação que une o Estado e o seu Direito, muito embora defendesse que o Estado constituía uma "corporación formada por un pueblo, dotada de un poder de mando originario y asentada en un determinado territorio". (JELLINEK, G. Teoría general del estado... p. 175 e 365)
} 
Legislativo, Executivo e Judiciário) constitui mecanismo de garantia de consentimento à tributação e da liberdade, ligado de forma umbilical ao princípio da legalidade. ${ }^{79}$

No que se refere à segurança jurídica, pode-se afirmar que tal valor apresenta duas facetas: uma relativa à chamada função certeza e outra concernente à denominada função justiça. Enquanto a primeira faceta persegue a previsibilidade jurídica, a última busca o respeito aos direitos fundamentais. ${ }^{80,81}$

Cumpre ressaltar a importância suprema da segurança jurídica, já que ela exige que a lei tenha um determinado conteúdo, constituindo uma genuína barreira imposta à Administração Tributária diante do contribuinte. Com efeito, a segurança jurídica: (i) na função certeza, busca proporcionar ao contribuinte o prévio conhecimento de quais atos serão ou não tributados pela legislação tributária e com qual intensidade (i.e., possibilidade de determinar o quantum devido); e, (ii) na função justiça, exige que a configuração do tributo em lei seja justa, respeitando direitos fundamentais do contribuinte (isonomia, mínimo existencial, proibição ao confisco, imunidades etc.).

Nesse passo, para que a segurança jurídica seja proporcionada, é necesssária a demarcação prévia e clara da regra-matriz de incidência tributária em lei ordinária, de modo que fique evidente o campo de atuação estatal na cobrança do tributo. Como salientado acima, não basta a lei por si só; a lei deve ter conteúdo tal que proporcione certeza, previsibilidade jurídica ao contribuinte, com respeito aos direitos fundamentais desse.

Logo, o princípio da legalidade tributária constitui um meio de garantia da segurança jurídica e da liberdade, as quais, pode-se afirmar, constituem duas facetas da mesma moeda.

\footnotetext{
79 José Maria de Arruda Andrade indica que as duas chaves principais do Estado de Direito são "a legalidade/limite e a separação de poderes" (ANDRADE, José Maria Arruda. Decisões Políticas, Legalidade Tributária e Limites da Interpretação. Revista de Direito Tributário da APET, São Paulo, v. 8, p. 106, 2005.)

${ }^{80}$ Acerca da função-certeza e função-justiça da segurança jurídica, vide FERRAZ JR., Tércio Sampaio. Segurança Jurídica e Normas Gerais Tributárias. Revista de Direito Tributário, São Paulo, Malheiros, v. 1718, p. 51, jul./dez. de 1981.

${ }^{81}$ Paulo de Barros Carvalho afirma que a segurança jurídica é um sobreprincípio que engloba a legalidade, a igualdade, a irretroatividade, a anterioridade, etc. (CARVALHO, Paulo de Barros. O Princípio da Segurança Jurídica em Matéria Tributária. In: LIMA, Aristóteles Moreira; LOBO, Marcelo Jatobá (coord.) Questões Controvertidas em Matéria Tributária: uma Homenagem ao Professor Paulo de Barros Carvalho. Belo Horizonte: Fórum, 2004. p. 52 e seguintes).
} 


\section{I.D.2 Conteúdo do Princípio da Legalidade Tributária}

O artigo 150, I da Constituição Federal atual, estabelece o princípio da legalidade tributária como a exigência constitucional de que o poder de tributar seja exercido única e exclusivamente por meio de lei. É uma limitação ao poder de tributar, conforme a letra do texto constitucional.

Esse princípio está presente nas Constituições brasileiras desde a de 1.891, salvo a Carta de 1.937, estando presente também no Código Tributário Nacional, de $1966 .{ }^{82} \mathrm{O}$ artigo 97, III do referido Código, dispõe expressamente que somente a lei pode estabelecer a definição do fato gerador da obrigação tributária principal.

De acordo com tal princípio e sob a luz dos valores que busca proteger, para que um determinado evento seja tributado, é necessário que tal evento se conforme à hipótese prevista em lei ordinária, que deve dispor acerca do antecedente (aspectos material, temporal e espacial) e do consequente (aspectos pessoal e quantitativo ${ }^{83}$ ) da regra-matriz de incidência tributária. Para tanto, a lei deve ser editada conforme o processo legislativo exigido e deve conter um conteúdo tal que permita ao intérprete extrair dela um critério de decisão, de tal sorte que ele possa afirmar previamente se um determinado evento a ocorrer ou a ser realizado será tributado ou não, e com qual intensidade (quantum). E a lei editada sempre deve respeitar os direitos fundamentais do contribuinte.

A jurisprudência construída ao longo do tempo pelo Supremo Tribunal Federal demonstra a importância do princípio da legalidade como um meio de proteção do contribuinte. $^{84}$

\footnotetext{
${ }^{82}$ Vitor Nunes Leal comenta a presença do princípio da legalidade genérica na Constituição imperial do Brasil e também nas de 1891 e de 1934, e afirma que, mesmo tal princípio não tendo sido positivado na Constituição de 1937, ele deve ser considerado implícito, uma vez que o constituinte não aboliu o regime da legalidade. Tamanha é a importância da legalidade no Estado de Direito que a sua ausência no texto escrito não implica a sua inexistência. (LEAL, Vítor Nunes. Lei e Regulamento. Revista de Direito Administrativo, Rio de Janeiro: Departamento Administrativo do Serviço Público (Serviço de Documentação), n. 1, p. 374. 1945, e LEAL, Vitor Nunes. Lei e Regulamento. In: Problemas de Direito Público. Rio de Janeiro: Forense, 1960. p. 57).

${ }^{83}$ Com exceção dos tributos cujas alíquotas podem ser alteradas diretamente pelo Poder Executivo via decreto, conforme previsto na Constituição Federal.

${ }^{84}$ Não poderá, por exemplo, haver delegação do poder de fixar a alíquota de tributo para o Executivo, como decidido pelo Plenário do Supremo Tribunal Federal no caso da contribuição do salário educação (RE n. 290.079-6 SC, julgado pelo Pleno (maioria), em 17.10.2001), no caso da contribuição devida ao Instituto do
} 
O desenvolvimento do Estado Democrático e Social de Direito e a complexidade atual da vida econômica tornam desafiadora a aplicação do princípio da legalidade tributária em alguns casos e, consequentemente, a identificação dos limites de interação entre a lei e o regulamento.

Tais dificuldades, combinadas com a necessidade de a Administração Tributária aplicar a lei tributária em massa no Brasil, acarretaram e continuam a acarretar a introdução de leis no ordenamento jurídico que veiculam, diretamente ou em conjunto com a regulamentação, presunções e normas quantificadoras, as quais afastam a análise do caso isolado e passam a permitir a tributação em massa com base em padrões. Exemplos dessas leis são aquelas que tratam do SAT e do ICMS cobrado com base no mecanismo de substituição tributária, discutidas ao longo do presente estudo. Essas leis tendem a reduzir as questões envolvidas na interpretação da lei, refletindo a aplicação dos princípios da praticabilidade e da eficiência, os quais se encontram em constante tensão com o princípio da legalidade (na vertente segurança jurídica, função "justiça") e da igualdade. ${ }^{85}$ A aplicação harmônica desses princípios exige que as normas presuntivas tenham caráter iuris tantum e que as normas quantificadoras possam ser discutidas com base em outras avaliações apresentadas pelo contribuinte, o que, na prática, nem sempre ocorre, em prejuízo do contribuinte.

Além disso, existem casos onde a lei faz reenvios à regulamentação fiscal, devendo-se observar se tais reenvios tornam, de forma inapropriada, o regulamento mais importante do que a lei.

Feitos esses comentários iniciais sobre o princípio da legalidade tributária, deve-se agora examinar os dois aspectos da legalidade tributária, quais sejam: material e formal, os quais são abordados a seguir.

Açúcar e Álcool - IAA (RE n. 214.206-9 AL, julgado pelo Pleno (maioria), em 15.10.1997) e da contribuição incidente nas exportações de café, devida ao Instituto Brasileiro do Café - IBC (RE n. 191.0445 SP, julgado pelo Pleno (unanimidade), em 18.09.1997). A lei não poderá também estabelecer uma alíquota que varie de acordo com uma norma editada por terceiro, seja, por exemplo, componente do Poder Executivo ou do próprio Poder Legislativo. O Plenário do Supremo Tribunal Federal, no julgamento do recurso extraordinário interposto pelo Estado de Pernambuco decidiu que a variação da alíquota do imposto de transmissão causa mortis, em correspondência com o limite máximo fixado em resolução do Senado Federal viola o princípio da legalidade (RE n. 213.266-7, julgado pelo Pleno (unanimidade), em 20.10.1999). 


\section{I.D.2.1 Problemática do Aspecto Material}

$\mathrm{O}$ aspecto material do princípio da legalidade tributária (reserva absoluta de lei) constitui a exigência de o conteúdo da lei dispor, de forma suficiente e clara, acerca da regra-matriz de incidência tributária. É esse aspecto que permite ao contribuinte saber previamente se os seus atos estarão sujeitos à tributação e com qual intensidade. É esse aspecto que assegura, assim, a liberdade/segurança jurídica de o contribuinte poder decidir se vai praticar o evento que, segundo a lei, será tributado.

Para que a norma tributária proporcione tal previsibilidade, é necessário que a linguagem utilizada para enunciá-la faça um sentido específico das perspectivas semântica, sintática e pragmática.

Do mesmo modo, para que o princípio da legalidade tributária tenha sua força de contenção plena diante do Estado, o legislador deve observar a Lei Complementar n. 95/98, que trata da boa técnica legislativa. A lei deve ser harmônica e deve observar as regras constantes da referida lei complementar, como modo de proporcionar segurança jurídica.

Especificamente com relação ao aspecto semântico da linguagem utilizada para materializar a norma tributária, é necessário discorrer acerca da questão dos conceitos ${ }^{86,87}$

\footnotetext{
${ }^{85}$ Há também a possibilidade de os princípios da praticabilidade e da eficiência estarem em colisão com outros princípios como o da capacidade contributiva ou do confisco, o que deve ser verificado em cada caso.

${ }^{86}$ A realidade é expressa na linguagem, mas as palavras e termos linguísticos constroem uma realidade própria, na qual o sentido das palavras e termos não está propriamente neles mas sim no processo de interpretação realizado pelo homem. Como o homem está inserido em uma comunidade desde o seu nascimento, a qual aceita ou não a utilização de determinadas palavras ou termos com um certo sentido, ele não está livre para tentar usar a palavra com qualquer sentido. Há uma pré-compreensão sobre o sentido de uma palavra ou termo na comunidade. Do mesmo modo, os conceitos (significado de algo, alma de uma palavra) também se constroem a partir das relações entre o homem e a comunidade e da forma como essa comunidade utiliza o referido conceito. Os conceitos não têm uma estrutura definida, mas são constituídos de um núcleo central (composto por dados prévios e seguros, que constituem as zonas de certeza positiva e negativa) e de um halo ou zona de penumbra (que pode gerar controvérsias e dúvidas). Os conceitos determinados e indeterminados não se diferenciam pela presença da zona de penumbra, mas sim pela extensão dessa. Não se aceita a concepção platônica e essencialista de conceito, no sentido de que há apenas um conceito para explicitar a realidade, conceito esse que refletiria uma ideia universal e imutável e que só existiria em um mundo ideal. (cf. MELLO, Celso Antônio Bandeira. Discricionariedade e Controle Jurisdicional. 2. ed. São Paulo: Malheiros, 1993. p. 28, e IZELLI, Anna Flávia de Azevedo. Limites à Interpretação e Aplicação de Conceitos Jurídicos Indeterminados Presentes na Norma Tributária. 2005. Dissertação (Mestrado em Direito) - Faculdade de Direito da Universidade de São Paulo, São Paulo, 2005, capítulo III). Eros Grau critica essa visão, afirmando que a indeterminação não está no conceito em si, mas
} 
indeterminados e ambíguos, que podem criar complexidades na construção da norma diante da linguagem utilizada na lei.

Os conceitos ambíguos são aqueles que apresentam dois sentidos, tais como: "manga", fruta ou parte de uma camisa; "cabo", incidente geográfico (e.g., Cabo de Santo Agostinho) ou militar, etc. Geralmente, a dificuldade envolvendo a compreensão dos conceitos ambíguos é menor e é solucionada pelo próprio contexto no qual a norma se insere ou será aplicada.

Já os conceitos usualmente chamados de indeterminados são aqueles que contêm em sua estrutura uma zona de incerteza maior, não sendo a presença dessa zona por si só o critério determinante para sua classificação como indeterminados, já que todos os conceitos possuem uma dose de indeterminação. ${ }^{88}$ São exemplos clássicos de tais conceitos os seguintes: "renda", "valor venal", "mulher honesta", "adultério", etc. A complexidade envolvendo a compreensão dos conceitos indeterminados para fins de construção da norma é maior, tendo, por tal razão, a doutrina se debruçado detidamente sobre a possibilidade de utilização desses conceitos na lei fiscal, sob luz do princípio da legalidade tributária, como se analisa a seguir.

O princípio da legalidade material é, para Alberto Xavier, o princípio da tipicidade da tributação. O referido autor resgatou e explorou, na década de setenta, o estudo do princípio da tipicidade fiscal, Tatbestandsmässigketi, desenvolvido por Albert Hensel na década de vinte. ${ }^{89}$ Alberto Xavier sustenta que, para a exigência de um tributo: "não basta a lei; é necessária uma lei 'qualificada", 90,91

sim no termo linguístico, de tal sorte que não existiriam os chamados conceitos indeterminados, que constituiriam, na visão desse autor, noções. (GRAU, Eros. O Direito Posto e o Direito Pressuposto. 7. ed. São Paulo: Malheiros, 2008. p. 195 e seguintes).

${ }^{87}$ Alf Ross afirma que toda palavra é vaga (indeterminada) e a maioria delas é também ambígua (ROSS, Alf. Direito e Justiça. Tradução: Edson Bini. 2. ed. Barueri, SP: EDIPRO, 2007).

${ }^{88} \mathrm{O}$ conceito indeterminado também não se confunde com a lacuna, que não é uma indeterminação, mas sim uma espécie de conceito negativo, porque indica um "vazio" jurídico, onde há uma falta. Vide BOBBIO, Norberto. Teoria do Ordenamento Jurídico. 10. ed. Brasília: Editora UnB, 1999.p. 115 e seguintes, e TORRES, Heleno. Interpretação e Integração das Normas Tributárias - Reflexões Críticas. In: TORRES, Heleno (coord.) Tratado de Direito Constitucional Tributário: Estudos em Homenagem a Paulo de Barros Carvalho. São Paulo: Saraiva, 2005. p. 121.

${ }^{89}$ XAVIER, Alberto. Os Princípios da Legalidade e da Tipicidade..., p. 58.

90 XAVIER, Alberto. Tipicidade da Tributação, Simulação e Norma Antielisiva. São Paulo: Editora Dialética, 2001. p.17.

91 Note-se que Alberto Xavier também fundamenta o princípio da tipicidade no artigo 146, III, $a$ da Constituição Federal. XAVIER, op. cit., p. 22. 
Alberto Xavier defende que o princípio da tipicidade da tributação pró́be a utilização de conceitos indeterminados na formulação das leis tributárias. Como a lei deve conter o critério de decisão para um caso concreto, o seu conteúdo não poderia implicar uma delegação de poder em virtude de uma predeterminação indeterminada. Nas palavras do mencionado autor, tal delegação acontece quando são utilizados na lei "conceitos indeterminados (Unbestimmte Rechtsbegriffe), conceitos porosos, dotados de vagueness, fuziness, open texture que, pela sua vaguidade e imprecisão, podem constituir um instrumento de competência de decisão, permitindo à Administração ou ao juiz uma atividade criadora do Direito". ${ }^{92}$

Em sentido semelhante, Misabel Abreu Machado Derzi também entende que conceitos determinados devem ser utilizados na lei, como desdobramento do princípio da legalidade material, já que esses proporcionam uma garantia mais forte diante da Administração Tributária. Para Misabel Derzi, o princípio da legalidade constitui o princípio da especificação conceitual, que exige que o legislador estabeleça um conteúdo mínimo da norma tributária, com a utilização de conceitos determinados. ${ }^{93}$ Para Derzi, os conceitos determinados não se confundem com tipos, posto que os últimos, que também estão presentes no ordenamento jurídico (mas em menor número), são abertos e flexíveis por natureza, não proporcionando a mesma garantia do que aquela decorrente da utilização de conceitos determinados. Derzi entende, portanto, não ser tecnicamente adequado denominar o princípio da especificação conceitual de princípio da tipicidade (tratam-se de conceitos de ordem diferentes). ${ }^{94,95,96,97}$

\footnotetext{
${ }^{92}$ XAVIER, op. cit., p. 28.

${ }^{93}$ BALEEIRO, Aliomar. Direito Tributário..., p. 622.

94 "Em resumo, pode-se dizer que: a segurança jurídica, a legalidade formal e material e a estabilidade das relações jurídicas são garantias fundamentais, constitucionalmente consagradas; a conceitualização legal, determinada e especificante, sendo mero desdobramento do princípio da legalidade, visto em seu grau material absoluto, representa também uma garantia constitucional; a tipicidade, não obstante, sendo a criação de ordens ou tipos, por natureza flexíveis e abertos, é instrumento frágil de garantia, enquanto a conceitualização fechada, criadora de classes e espécies, é meio assecuratório mais forte, reforçador da segurança (como direito) e da estabilidade das relações jurídicas." (BALEEIRO, Aliomar. Limitações Constitucionais...p. 131.)

${ }^{95}$ Mais adiante, na mesma obra citada na nota anterior (p. 138-139) a autora afirma: "Ora, o que prevalece no Direito Tributário não é a tipologia, mas a classificação; não é o tipo, mas o conceito. A legalidade estrita, a segurança jurídica, a uniformidade, a praticabilidade e a rigidez da discriminação constitucional de competência determinam a tendência conceitual classificatória prevalente no Direito Tributário. [...] A graduabilidade e a flexibilidade são restritas ao interior de certas espécies tributárias - imposto sobre a importação, a exportação, a produção industrial, o crédito, o câmbio, o seguro e a guerra - com relação às quais o Poder Executivo pode alterar a alíquota. A lei só fixa os limites dentro dos quais será exercida a discricionariedade administrativa. A política aduaneira e econômico-financeira do governo são critérios a
} 
Por outro lado, existem autores que não concordam com a visão tradicional acima a respeito da legalidade tributária e da proibição de utilização de conceitos indeterminados na lei ordinária. Para esses autores, a utilização de conceitos indeterminados em lei é admissível ou mesmo inevitável.

Ricardo Lobo Torres afirma ser ingênua a crença de que seria possível o direito tributário trabalhar exclusivamente com conceitos determinados. ${ }^{98}$ Ricardo Lobo Torres admite a utilização de conceitos indeterminados na lei tributária, o que permite uma maior margem de atuação da Administração Tributária na edição de regulamentos, ressalvando sempre a possibilidade de revisão judicial. Esse autor também defende que, em virtude da presença dos conceitos indeterminados em lei e da impossibilidade atual de uma reserva

partir dos quais se graduam tais tributos, segundo um "tanto mais... quanto mais" (que subentende um "tanto menos... quanto menos, ou um "tanto mais... quanto menos"). A norma constitucional admite, dessa forma, que a lei estruture certos tributos de forma flexível. Infiltra-se nessas estruturas a possiblidade de graduação por comparação ou proporção (direta ou inversa)."

${ }^{96}$ Misabel Derzi entende que o sistema jurídico presta-se a fornecer estabilidade, segurança jurídica, com a proteção da confiança do contribuinte. Vide DERZI, Misabel. Mutações, Complexidade, Tipo e Conceito sob o Signo da Segurança Jurídica e da Proteção de Confiança. In: TORRES, Heleno. (coord.) Tratado de Direito Constitucional Tributário: Estudos em Homenagem a Paulo de Barros Carvalho. São Paulo: Saraiva, 2005. p. 245.

${ }^{97}$ Não se pode confundir aqui a adoção do princípio da especificação conceitual por Misabel Derzi com a aceitação por essa autora da utilização do "modo de pensar tipificante"/"modo de raciocinar padronizante" como meio de aplicação do princípio da praticabilidade (com a utilização de presunções, pautas, etc.). Para normas de aplicação em massa, Misabel Derzi aceita a utilização de tipo, compreendido como o comum, o caso médio; trata-se de uma questão de aplicação da lei, uma técnica de execução (e não de conceito de ordem ou de interpretação). Nesse caso, o tipo é construído em norma executiva e estabelecido como o padrão, rígido, inclusive estabelecido numericamente, com o desprezo das diferenças individuais dos casos isolados. O modo de pensar padronizante objetiva viabilizar ou simplificar a execução de normas jurídicas, sendo que apenas a lei pode instituir presunções e esquematizar e determinar a média da tributação. Deve sempre haver uma "válvula de escape" na norma que permita o contribuinte ser tributado conforme a sua capacidade contributiva individual, medida essa de justiça e de respeito à legalidade material. Nessa linha, a conformação ao tipo ou à tributação conforme a capacidade contributiva deve ser uma opção do contribuinte. (DERZI, Misabel Abreu Machado. Legalidade Material, Modo de Pensar "Tipificante" e Praticidade no Direito Tributário. In: Justiça Tributária. (Publicação do $1^{\circ}$ Congresso Internacional de Direito Tributário IBET). São Paulo: Max Limonad, 1998. p. 627-650).

98 "Supera-se também a crença tanto ingênua na possibilidade de permanente fechamento dos conceitos tributários, como se nesse ramo do direito houvesse a perfeita adequação entre pensamento e linguagem e se tornasse viável a plenitude semântica dos conceitos. O direito tributário, como os outros ramos do direito, opera também por conceitos indeterminados, que deverão ser preenchidos pela interpretação complementar da Administração, pela contra-analogia nos casos de abuso do direito e pela argumentação jurídica democraticamente desenvolvida. (...) Há zonas de imprecisão nas leis tributárias e um certo espaço não preenchido pelo próprio legislador que abrem à Administração o poder de complementar a regra da imposição fiscal. Claro que sempre resta a possibilidade de se contrastar tal interpretação administrativa com a do Judiciário, que prevalecerá afinal. Mas não se pode eliminar a competência administrativa na elaboração do regulamento, com eficácia sobre terceiros. [...] No Brasil o positivismo tem procurado minimizar a importância da interpretação administrativa com defender da existência da tipicidade fechada, que é contradictio in terminis, e da legalidade absoluta, como já vimos antes [...]." (TORRES, Ricardo Lobo. Tratado de Direito Constitucional..., p. 425-426 e 435.) 
absoluta da lei, a segurança jurídica depende não mais só da lei, mas também da Administração Tributária e do Poder Judiciário. ${ }^{99}$

Marco Aurelio Greco tem entendimento semelhante e não considera que o princípio da legalidade tributária exigiria a utilização exclusiva de conceitos fechados, também afirmando que a imprecisão é inerente à linguagem. ${ }^{100}$

Além disso, Greco, ao afirmar que tudo é questão de grau na interpretação, defende que o raciocínio subsuntivo na aplicação da lei tributária (que conteria conceitos determinados) já não captura a realidade de forma apropriada para fins tributários, sendo necessário trabalhar com conceitos indeterminados na construção da norma, de tal modo a se levar em conta os crescentes "valores sociais e culturais positivos e indutores (e não meramente negativos e protetivos) que o ordenamento quer ver atendidos". ${ }^{101}$

Do até aqui exposto, pode-se reconhecer que há uma controvérsia doutrinária acerca do conteúdo preciso do aspecto material do princípio da legalidade. Parte da doutrina defende o dever de utilização exclusiva de conceitos determinados na lei ordinária que fixa a regra-matriz de incidência tributária. Outros autores entendem que conceitos indeterminados são aceitáveis e que a sua utilização é até mesmo uma questão inerente à linguagem. Ricardo Lobo Torres entende que a Administração Tributária fica também obrigada a proporcionar segurança jurídica, defendendo que a linguagem utilizada em lei com conceitos indeterminados - não é capaz de refletir com perfeição o pensamento. Marco Aurelio Greco sustenta, além da questão relativa às limitações da linguagem, que apenas a utilização dos conceitos indeterminados permitiria à norma tributária alcançar plenamente os seus objetivos, sob a luz da capacidade contributiva e de valores sociais e culturais.

Tal controvérsia doutrinária também foi objeto de disputas judiciais, o que é natural, tendo em vista o fato de conceitos indeterminados serem muitas vezes utilizados

\footnotetext{
${ }^{99}$ TORRES, op. cit., p. 433.

100 "Mas interpretação para definir o alcance dos termos utilizados pelo legislador é admissível. Fica, porém, o problema, pois é preciso ter presente que sempre vai-se utilizar uma linguagem. E a linguagem do Direito é natural - aquela pela qual as pessoas se comunicam - e sendo assim, ela em si mesma é imprecisa. Em si mesma ela comporta uma fixa de indefinição. Não que ela seja indeterminável; ela é apenas indeterminada naquele momento. Ela é determinável (no futuro) mas indeterminada (no presente)." (GRECO, Marco Aurelio. Planejamento Fiscal e Interpretação da Lei Tributária. São Paulo: Dialética, 1998. p. 70.)
} 
na lei ordinária na prática. Como se perceberá no curso do presente trabalho, os autores que reconhecem e admitem a utilização de conceitos indeterminados na legislação ordinária estão mais próximos da realidade atual, não sendo menos importante, entretanto, a posição daqueles que defendem a obrigação de o legislador utilizar, exclusivamente ou sempre que possível, conceitos determinados na lei tributária, tendo em vista a maior garantia proporcionada por esses.

Um julgamento recente, envolvendo conceitos indeterminados que merece atenção, é o caso SAT, mencionado acima. Nesse caso, o Supremo Tribunal Federal aceitou como constitucional a possibilidade de o Executivo completar, via regulamento, a regra-matriz de incidência da referida contribuição SAT estabelecida em lei, no artigo 22, II da Lei n. $8.212 / 91$.

O tribunal considerou como legítima a atribuição de poder para o Executivo interpretar e completar, em regulamento, os conceitos de "atividade preponderante" e "grau de risco leve, médio e grave", constantes da lei ordinária. Ou seja, a Corte reconheceu como válido o poder do Executivo de dar maior precisão aos referidos conceitos, o que ao final permite a identificação da alíquota aplicável de 1\%, $2 \%$ ou $3 \%$.

O Supremo Tribunal Federal considerou que tal transferência de poder não constituía uma delegação pura, mas sim uma atribuição de poder vinculada a padrões fixados em lei, de modo que o regulamento constituía um regulamento intra legem, que não implicava inovação da ordem jurídica, ${ }^{102}$ até porque a base de cálculo e as alíquotas da contribuição estavam estabelecidas em lei.

Dessa maneira, o efeito desse julgamento foi reconhecer a legitimidade de atribuição ao Executivo do poder de avaliar o grau de risco efetivo de atividades econômicas, o que permitiu ao Executivo enquadrar, em regulamento, tais atividades segundo o seu grau de risco e, por consequência, o poder de fixar, dentre as alíquotas previstas em lei, a alíquota específica aplicável a uma determinada atividade. O Supremo

\footnotetext{
${ }^{101}$ GRECO, op. cit., p. 170-171.

102 VELlOSO, Carlos Mário da Silva. Do Poder Regulamentar. Revista de Direito Público, São Paulo, Editora Revista dos Tribunais, v. 65, p. 46, 1983. Nesse artigo, o autor faz a distinção entre regulamentos de execução, o falso regulamento de execução, o regulamento praeter legem e o regulamento autorizado (intra legem).
} 
decidiu que o regulamento decorrente do exercício dessa atividade executiva foi editado dentro dos limites da lei, o que representa a aceitação, nesse caso, do preenchimento de padrões fixados em lei pelo Chefe do Poder Executivo, o que pode ser considerado, inclusive, como uma atividade tipificante limitada, no sentido de permitir a aplicação da lei em massa. ${ }^{103}$

Disso tudo decorre que a previsibilidade da tributação que deveria ser proporcionada apenas pela lei pode passar a depender, em determinados casos, de um ato normativo do Chefe do Poder Executivo, que pode completar a lei. Nesses casos, o regulamento passa a ter um papel mais importante, porque fica obrigado, da mesma forma que a lei, a proporcionar a segurança jurídica que não foi assegurada inteiramente em lei, em razão da utilização de conceitos indeterminados.

A concentração de poder nas mãos do Poder Executivo decorrente dessa realidade, que constitui uma inegável flexibilização do aspecto material da legalidade, faz com que a atividade regulamentar necessite de um maior controle, sob risco de o Executivo não proporcionar a segurança jurídica e oprimir o contribuinte, o que é estudado abaixo também sob a luz do princípio da separação de poderes.

Cumpre ressaltar que esse importante papel do Poder Executivo de precisão de conceitos indeterminados utilizados em lei não significa que haja discricionariedade ${ }^{104}$ ou discricionariedade técnica ${ }^{105,106}$ diante da lei ordinária, envolvendo juízos de conveniência e oportunidade na escolha de indiferentes jurídicos, como há no Direito Administrativo.

\footnotetext{
${ }^{103}$ DERZI, Misabel de Abreu Machado. Direito tributário, direito penal..., p. 329. A decisão no caso da contribuição SAT não significa que o Supremo Tribunal Federal tenha aceitado que uma norma de hierarquia inferior converta em presunção ou ficção o estabelecido em norma de hierarquia superior. Por essa razão, pode-se afirmar que foi aceita atividade tipificante limitada, dentro dos limites da lei, em regulamento intra legem.

104 "Opostamente, haveria atuação discricionária quando, em decorrência do modo pelo qual o Direito regulou a atuação administrativa, resulta para o administrador um campo de liberdade em cujo interior cabe interferência de uma apreciação subjetiva sua quanto à maneira de proceder nos casos concretos, assistindolhe, então sobre eles prover na conformidade de uma intelecção, cujo acerto seja irredutível à objetividade e ou segundo critérios de conveniência e oportunidade administrativa. (...) Então, quando realmente existe discricionariedade, não há apenas um problema de não se poder provar algo; há o problema de não se poder saber qual é a solução ótima. São coisas totalmente distintas não poder saber o que algo é (ou não é) e não poder prová-lo. Aliás, esta segunda situação pressupõe a primeira.” (MELLO, Celso Antônio Bandeira. Discricionariedade... p. 9 e 42).

${ }^{105}$ A discricionariedade técnica é uma espécie de discricionariedade que envolve a aplicação de técnicas tão complexas que justificariam a decisão da administração, que não seria passível de controle judicial a não ser que houvesse erro manifesto.
} 
Há na atividade de precisar conceitos indeterminados, isso sim, a aplicação de juízos de legalidade, passível de controle pelo Poder Judiciário. ${ }^{107}$

Contudo, não se pode negar que, na aplicação de juízos de legalidade diante de um conceito indeterminado, pode teoricamente haver mais de uma solução correta, o que permite a construção de mais de uma norma regulamentar pelo Poder Executivo. ${ }^{108}$ Nesse último caso, a norma criada pela Administração Tributária deve estar fundada em argumentos jurídicos e, dependendo do caso, em argumentos técnicos também, devendo ser o resultado de uma interpretação razoável ${ }^{109}$ e proporcional $^{110}$ da lei. ${ }^{111,112}$

${ }^{106}$ GRAU, Eros Roberto. Conceitos Indeterminados. In: Justiça Tributária (Publicação do $1^{\circ}$ Congresso Internacional de Direito Tributário - IBET). São Paulo: Max Limonad, 1998. p. 124.

${ }^{107}$ Celso Antônio Bandeira de Mello entende que a discricionariedade decorre da existência dos conceitos indeterminados, fluidos (MELLO, Celso Antônio Bandeira. Discricionariedade... p. 48). De outro lado, Eros Roberto Grau defende que a discricionariedade decorre de atribuição expressa em norma jurídica válida (e.g., dar porte de arma), sendo a interpretação de conceitos indeterminados uma atividade que envolve apenas juízos de legalidade, não podendo se falar em discricionariedade nesse caso. Para Grau, a indeterminação existe apenas na norma, não acarretando uma situação de indeterminação quando de sua aplicação, momento no qual se pode averiguar a aplicação adequada do conceito. (GRAU, Eros. O Direito Posto... p. 203 e 222)

${ }^{108}$ Nessa situação haveria uma margem de livre apreciação da Administração Tributária, controlável pelo Poder Judiciário, como explica Ana Paula Dourado (DOURADO, Ana Paula. O Princípio da Legalidade Fiscal. Tipicidade, conceitos jurídicos indeterminados e margem de livre apreciação. Coimbra: Almedina, 2007. p. 425 e seguintes).

${ }^{109}$ Sobre o princípio da razoabilidade, vide TORRES, Ricardo Lobo. Tratado de Direito Constitucional..., p. 228 e seguintes.

${ }^{110}$ Sobre o princípio da proporcionalidade, vide ÁVILA, Humberto. Proporcionalidade e Direito Tributário. In: SCHOUERI, Luis Eduardo (Coord.). Direito Tributário - Homenagem a Alcides Jorge Costa. Vol. I. São Paulo: Editora Quartier Latin, 2003, p. 329-348 e MENDES, Gilmar. A Proporcionalidade na Jurisprudência do Supremo Tribunal Federal. Repertório de Jurisprudência IOB, São Paulo, Caderno 1, n. 23/94, p. 475, $1^{\text {a }}$ quinzena de dez.de 1994.

${ }^{111}$ É o caso, por exemplo, da fixação das taxas anuais de depreciação pela Receita Federal do Brasil para fins do imposto de renda das pessoas jurídicas, conforme o artigo 57, parágrafo $3^{\circ}$ da Lei $\mathrm{n}$. 4.506/64, regulamentado no artigo 310 do Regulamento do Imposto de Renda (Decreto n. 3.000/99) e nas instruções normativas n. 162/98 e n. 130/99. Exige-se a compreensão do conceito "depreciação", bem como a identificação concreta dos percentuais que refletem o desgaste dos bens examinados no tempo, com a identificação do prazo de sua vida útil. Outro exemplo no campo do imposto de renda é o caso dos percentuais de royalties admitidos como dedutíveis, considerando-se os tipos de produção ou atividades, os quais são estabelecidos e devem ser revistos periodicamente de acordo com ato do Ministro da Fazenda, segundo o artigo 12, parágrafo primeiro da Lei n. 4.131/62, regulamentado no artigo 355 do Regulamento do Imposto de Renda, e nas Portarias n. 436/58, 113/59, 314/70 e 60/94.

${ }_{112}$ Outro relevante exemplo, agora na esfera estadual, é o caso da fixação da margem de valor agregado para fins de determinação da base de cálculo do ICMS na sistemática da substituição tributária para frente, conforme dispõe o artigo $8^{\circ}$ da Lei Complementar n. 87/96. O estabelecimento da referida margem de valor agregado nas operações envolvendo uma determinada mercadoria exige o levantamento de preços usualmente praticados no mercado considerado, o que demanda não só a compreensão do conceito de "margem de valor agregado" (um juízo de legalidade), como também a adequada identificação concreta dos preços geralmente praticados no mercado sob análise (um juízo técnico, que abrange a devida delimitação do universo a ser pesquisado e a forma de colheita da amostra, com a participação do contribuinte para comentar as evidências reunidas e a adequação do critério de sua colheita). O parágrafo $4^{\circ}$ desse dispositivo exige que a lei determine os critérios para a fixação da margem de valor agregado. 
Ainda nesse ponto, ressalve-se que, para que o princípio da legalidade tributária não seja esvaziado, o legislador deve ter o cuidado de utilizar conceitos indeterminados que tenham uma densidade mínima que permita o entendimento da norma e a extração de um critério de decisão (grau mínimo de determinação). A não observação desse cuidado implica o risco de a regulamentação tributária assumir papel que não lhe compete, caracterizando uma indevida inversão de hierarquia entre lei e regulamento. A utilização de um conceito demasiadamente indeterminado pode significar a eliminação de qualquer previsibilidade, como se o Poder Legislativo não tivesse feito uma escolha, o que seria uma autorização legal para a opressão fiscal pelo Poder Executivo, fora do controle do Poder Judiciário (que não teria um padrão mínimo de referência na lei).

O desafio aqui é reconhecer se o grau mínimo de determinação foi assegurado em lei, de tal modo que a observação ou não do conteúdo da dita lei pela Administração Tributária possa ser verificada pelo Poder Judiciário. ${ }^{113}$ Não só isso, a lei ordinária também deve permitir que a interpretação de um dispositivo isolado ou de um conjunto deles implique a identificação da norma tributária que respeite as balizas constitucionais do tributo. $^{114}$

Como se pode perceber do até aqui explorado, muitas são as questões envolvendo o aspecto material do princípio da legalidade, o qual constitui efetivamente um princípio, sendo uma norma que comporta ponderação e gradação, não sendo aplicável de um modo “tudo ou nada", como uma regra. ${ }^{115}$

\footnotetext{
${ }^{113}$ Ana Paula Dourado reconhece a colaboração da teoria da essencialidade na discussão da identificação da densidade mínima exigida em lei. A autora afirma que a referida teoria substitui a justificação da reserva de lei do racional de que a lei deve ter como objeto a declaração da liberdade e da propriedade diante do Estado para a ideia de que a lei deve regular os direitos fundamentais. Para a autora, esse racional não é suficiente, devendo-se levar em conta a vantagem proporcionada pela flexibilidade dessa teoria (exigindo maior densificação quanto mais importante a matéria; uma relação de proporcionalidade), o que é criticado por outros autores, como ela mesma reconhece. Ana Paula Dourado afirma que o maior problema dessa teoria é a questão da sua efetividade nos tribunais, tendo havido o reconhecimento de inconstitucionalidades apenas em casos excepcionais. (DOURADO, Ana Paula. O princípio da legalidade..., p. 349 e seguintes)

114 O Supremo Tribunal Federal já teve a oportunidade de reconhecer que a lei tributária não tinha a densidade normativa mínima apta a permitir a cobrança de tributo do contribuinte. Não foi o caso de discussão da densidade mínima de um conceito isolado na lei, mas sim do sistema de regras instituídas para cobrança do ICMS no transporte aéreo. Foi o caso da ADIN 1.600/DF, no qual o Plenário do Supremo, por maioria, reconheceu a inconstitucionalidade dos dispostivos que tratavam da cobrança do ICMS no transporte aéreo de passageiros intermunicipal, interestadual, internacional, bem como de transporte aéreo internacional de cargas, já que a Lei Complementar n. 87/96 não disciplinou de forma adequada a matéria como deveria, dando formas de resolução de conflitos de competência entre as unidades da federação.

115 Adota-se aqui a distinção entre princípios e regras, como exposta por Ronald Dworkin (DWORKIN, R. Levando os Direitos a Sério. Tradução: Jefferson Luiz Camargo. 2. ed. São Paulo: Martins Fontes, 2007, 3942). Não é objeto do presente trabalho aprofundar o estudo da natureza dos "princípios" e "regras", mas cabe
} 
Quando se flexibiliza esse princípio com a aceitação pelo Poder Judiciário de que o regulamento pode dar o sentido preciso de conceitos indeterminados utilizados em lei (com o exercício de padronização limitada administrativa), com maior concentração de poder no Executivo, é necessário que sejam pensados novos mecanismos de proteção do contribuinte, posto que o risco de opressão fiscal aumenta.

\section{I.D.2.2 Problemática do Aspecto Formal}

Por sua vez, o aspecto formal do princípio da legalidade tributária (reserva de lei formal) está relacionado com o veículo introdutor da norma jurídica, de modo que apenas a lei pública, editada com o respeito ao processo legislativo exigido, pode introduzir ou majorar um tributo no ordenamento jurídico brasileiro (nullum tributum sine leggem scripta). Com efeito, somente se pode reconhecer a presença do consentimento do contribuinte ao ordenamento jurídico quando há uma lei ordinária editada por pessoa política competente e com a observação do processo legislativo cabível, que permita a participação do povo por meio de seus representantes. Não são aceitas leis secretas.

Dessa maneira, pode-se afirmar que o princípio da legalidade tributária, em seu sentido formal, constitui uma regra, que não admite ponderação ou flexibilização. $O$ tributo deve ser instituído por meio de lei ordinária, sob pena de esse tributo ser inconstitucional.

Lamentavelmente, algumas atitudes do próprio Poder Legislativo e do Poder Executivo violam o princípio da legalidade em seu sentido formal de forma deliberada, o que não se pode aceitar.

Um exemplo é o artigo 27 da Lei n. 10.865/2004, que delegou ao Poder Executivo o poder de reduzir e restabelecer as alíquotas das contribuições sociais para o Programa de Integração Social ("PIS”) e para o financiamento da Seguridade Social ("COFINS") sobre

apontar que o critério de distinção adotado por Dworkin pode muitas vezes não se mostrar adequado, por ser difícil isolar a regra do princípio, como aponta Lenio Luiz Streck (STRECK, L.L. Uma Abordagem Hermenêutica acerca do Triângulo Dialético de Canotilho ou de como ainda é Válida a Tese da Constituição Dirigente (Adequada a Países de Modernidade Tardia). In: LEITE, George Salomão; SARLET, Ingo 
as receitas financeiras no regime da não-cumulatividade. ${ }^{116} \mathrm{O}$ mesmo dispositivo legal atribuiu ao Executivo o poder de autorizar o desconto de créditos no cálculo dessas contribuições sobre despesas financeiras. Ora, por meio de tal dispositivo, o próprio Poder Legislativo permitiu ao Poder Executivo, por meio de uma delegação pura, deliberar acerca de matéria cuja natureza é inerente à lei (alíquota e base de cálculo), o que constitui uma genuína violação ao princípio da legalidade na sua vertente formal, realizada pelo próprio Poder Legislativo. ${ }^{117}$

Outro exemplo, apesar de não tratar da instituição ou majoração de tributos, é o caso da manutenção do parcelamento excepcional (conhecido como "PAEX") instituído pela Medida Provisória n. 303/2006 após a perda de vigência dessa, como reconhecido pelo Ato do Presidente da Mesa do Congresso Nacional n. 57/2006. Ora, o artigo 155-A do Código Tributário Nacional exige lei específica para a concessão de parcelamento, de tal modo que uma lei ordinária deveria ter sido editada para agasalhar o referido parcelamento após a perda de vigência da Medida Provisória n. 303/2006. Esse procedimento seguiria o caminho trilhado com relação às outras alterações à legislação tributária introduzidas pela Medida Provisória n. 303/2006 (e que foram objeto da Medida Provisória n. 351, convertida na Lei n. 11.488/2007). A manutenção do parcelamento em questão, após a perda de vigência da Medida Provisória n. 303/2006, constitui clara violação ao princípio da legalidade, em seu sentido formal.

Wolfgang (coord.). Direitos Fundamentais e Estado Constitucional. Estudos em Homenagem a J.J. Gomes Canotilho. São Paulo: Coimbra Editora e Revista dos Tribunais, 2009. p. 68).

${ }^{116}$ Art. 27. O Poder Executivo poderá autorizar o desconto de crédito nos percentuais que estabelecer e para os fins referidos no art. $3^{\circ}$ das Leis ns. 10.637, de 30 de dezembro de 2002, e 10.833, de 29 de dezembro de 2003, relativamente às despesas financeiras decorrentes de empréstimos e financiamentos, inclusive pagos ou creditados a residentes domiciliados no exterior. $\$ 1^{\circ}$ Poderão ser estabelecidos percentuais diferentes no caso de pagamentos ou créditos a residentes ou domiciliados em país com tributação favorecida ou com sigilo societário. $\$ 2^{\circ}$ O Poder Executivo poderá, também, reduzir e restabelecer, até os percentuais de que tratam os incisos I e II do caput do art. $8^{\circ}$ desta Lei, as alíquotas da contribuição para o PIS/PASEP e da COFINS incidentes sobre as receitas financeiras auferidas pelas pessoas jurídicas sujeitas ao regime de não-cumulatividade das referidas contribuições, nas hipóteses que fixar.

${ }^{117}$ Sobre esse dispositivo, são importantes os comentários de Luís Eduardo Schoueri: "Essa prática, tamanha sua sagacidade, além de violar a liberdade do contribuinte, desrespeitando a garantia da estrita legalidade tributária, coloca-o numa armadilha. A concessão de um benefício inconstitucional constrange os beneficiados a não o contestarem, sob risco de não gozarem do privilégio. Cria-se, assim, uma situação de grande poder. Mas não qualquer poder; um poder incontestável de quem, conforme sua vontade, pode distribuir determinadas indulgências para seus súditos. Os "amigos do Rei" receberão os frutos de sua benevolência, devendo demonstrar toda sua gratidão ao seu bondoso senhor, que os excluiu de serem tratados de acordo com o que diz - pasmem - a lei. Temos, assim, as consequências desta forma de desobediência à separação dos poderes: o temor e a reverência dos beneficiados e a impotência dos não-beneficiados, tornando-se mais do que atual a célebre frase atribuída à ditadura de Vargas: "aos amigos tudo, aos inimigos a lei”. No entanto, parece-nos que nem Getúlio seria capaz de tal astúcia.” (SCHOUERI, Luís Eduardo. A 
Os exemplos acima demonstram que a lei, em seu aspecto formal, é desrespeitada, inclusive com a conformação passiva do contribuinte pelo fato de esse ter sido favorecido pelo referido desrespeito. Não se pode, contudo, admitir a violação à regra da legalidade formal, visto que tal situação cria um precedente para que a mesma regra seja novamente quebrada no futuro (e com prejuízo ao contribuinte), com a instauração de insegurança jurídica.

Ainda nesse particular, muito embora se acredite que o aspecto formal do princípio da legalidade seja facilmente observado, sem maiores discussões jurídicas, práticas e até mesmo de cunho político, não se pode concordar com tal crença.

Com efeito, o uso inadequado e frequente de medidas provisórias, sem respeitar os requisitos constitucionais de relevância e urgência, bem como a inflação legislativa que se implantou, para regular e acompanhar a evolução da vida econômica, evidenciam práticas que acabam impedindo os representantes do povo de analisar os projetos de lei tributária (de conversão de MPs em lei, inclusive) de forma apropriada, de tal sorte a não se poder afirmar com segurança que: (i) haveria efetivamente um consentimento do contribuinte à tributação ou ao ordenamento jurídico; e (ii) a lei editada seria reflexo de justiça tributária.

Muito pelo contrário. Muitas leis tributárias são editadas sem a devida prévia análise pelo Congresso Nacional de suas consequências para o contribuinte. Em muitos casos, infelizmente, os representantes do Congresso Nacional e mesmo os membros de seus gabinetes não têm a formação técnica adequada e nem as informações necessárias para discutir matéria tributária, ${ }^{118}$ até porque essa matéria vem se tornando mais complexa e específica, com variações dependendo do segmento da economia contemplado na lei. ${ }^{119,120,121}$ Os membros do Ministério da Fazenda é que acabam exercendo essa função,

Suave Perda da Liberdade. Revista Direito Tributário Atual, Instituto Brasileiro de Direito Tributário. São Paulo: Editora Dialética, v. 18, p. 9, 2004.).

${ }_{118}$ CARVALHO, Paulo de Barros. Curso de Direito Tributário..., p. 5.

${ }^{119}$ Manoel Gonçalves Ferreira Filho explica que a inflação legislativa criou uma complexa babel jurídica, fenômeno ligado à falência dos Parlamentos como legisladores. Ferreira Filho afirma que os Parlamentos são lentos e sua composição não reflete necessariamente a escolha dos mais preparados, mas sim o resultado de um processo sensível à demagogia e à advocacia em causa própria. Tal cenário, como indica o constitucionalista, leva a uma tendência de o Legislativo delegar, cada vez mais, as suas funções ao Executivo. Conclui Ferreira Filho que a concentração de poder no Executivo, apesar de colocar a democracia em risco diante de uma teórica e possível tirania, é também uma medida de proteção da democracia, tendo em vista que apenas o Executivo está em posição de dar resposta aos anseios do povo de forma eficiente. A 
com base nos dados concretos que têm sobre a arrecadação, sobre as atividades econômicas, etc.

Além disso, a atribuição ao Presidente da República dos poderes de sanção e veto na elaboração de leis ordinárias (e de iniciativa legislativa) acaba por permitir que o Poder Executivo tenha um papel decisivo na edição de leis tributárias, permitindo que esse consiga a aprovação de leis tributárias pelo Congresso Nacional. A própria utilização inadequada de medidas provisórias para tratar de matéria tributária acaba por conferir mais força ao Executivo, tendo em vista que tal prática tende a desencorajar o Congresso Nacional a considerar alternativas de tributação além daquelas propostas em medida provisória. $^{122}$

$\mathrm{Na}$ trilha desse raciocínio, o poder legislativo não é exercido de forma exclusiva e genuína pelo Legislativo, de sorte a expressar a vontade do povo, mas implica, isso sim, a conjugação de vontades do Poder Legislativo e do Poder Executivo. A previsão constitucional $^{123}$ de que o veto presidencial pode ser rejeitado pelo Congresso Nacional não afeta essa conclusão, tendo em vista outros poderes ${ }^{124}$ exercidos pelo Poder Executivo na prática, que acabam por afetar o relacionamento desse com o Poder Legislativo.

Não se pode olvidar também o papel exercido pelos partidos políticos, que podem ter, ao mesmo tempo, representantes nos principais quadros do Poder Executivo e a maioria no Poder Legislativo. O ideal de que a "lei" é expressão da vontade geral do povo muitas vezes é, na realidade, superado pelo fato de que a "lei" reflete a vontade, o plano de governo do partido dominante. ${ }^{125,126,127}$ A utilização do mecanismo do voto de liderança constitui uma evidência dessa constatação. ${ }^{128}$

crise da lei também envolve, portanto, o problema dos Parlamentos e a crise da democracia. (FERREIRA FILHO, Manoel Gonçalves. Do Processo Legislativo. p. 12 e seguintes).

${ }^{120}$ Por essa razão, Odete Medauar afirma a existência de um déficit democrático decorrente da adoção cada vez menos transparente de políticas fiscais, cambiais, monetárias, etc. (MEDAUAR, Odete. O Direito Administrativo em Evolução. 2. ed. São Paulo: Editora Revista dos Tribunais, 2003, p. 96).

${ }^{121}$ Essa situação também ocorre na Alemanha. Vide nota de rodapé com os comentários do Professor Klaus Tipke acima (nota 8).

${ }^{122}$ Manoel Gonçalves Ferreria Filho afirma que o Legislativo assume uma atitude passiva no processo legislativo, sujeitando-se à liderança do Executivo. (Do Processo Legislativo..., p. 131).

${ }^{123}$ Artigo 66, parágrafo $4^{\circ}$ da Constituição Federal.

${ }^{124}$ Como, por exemplo, de controle das receitas públicas, da nomeação de dirigentes de empresas públicas, etc.

${ }^{125}$ GRAU, Eros Roberto. O Direito Posto..., p. 234. 
Do mesmo modo, deve-se reconhecer que o consentimento à tributação por meio da lei constitui uma utopia dissociada da realidade, tendo em vista que a vontade do povo apenas é expressa no voto (hoje eletrônico), de forma instantânea no dia das eleições. O voto é um mecanismo de escolha dos representantes por maioria, mas não do seu controle posterior. Após a eleição e durante o mandato, as ideias dos representantes eleitos a respeito de tributação não estão mais vinculadas ao povo ou dependentes do seu consentimento. $^{129}$

Portanto, pode-se afirmar que a edição da lei ordinária tributária não: (i) decorre de um processo totalmente democrático; e (ii) constitui obrigatoriamente uma medida de justiça tributária. Como demonstrado acima, o Poder Executivo tem forte influência e participação na atividade legislativa, de sorte que a atividade do Congresso Nacional e a "lei" propriamente dita não têm, na realidade, o poder de contenção desejado. ${ }^{130}$ Trata-se de um problema inerente ao processo legislativo dentro do contexto do Estado Democrático e Social de Direito e da dimensão desse.

Apesar disso tudo, não se pode negar que o Congresso Nacional continua a levantar, em algumas ocasiões, importantes discussões acerca do conteúdo de leis e medidas provisórias como no caso em que a pressão desse órgão e da sociedade acarretou a revogação pelo próprio Poder Executivo de dispositivos da Medida Provisória n. 232/2004, os quais aumentavam tributos.

\footnotetext{
${ }^{126}$ CLÈVE, Clèmerson Merlin. Atividade Legislativa do Poder Executivo. 2. ed. São Paulo: Editora Revista dos Tribunais, 2000. p. 50.

${ }^{127}$ Manoel Gonçalves Ferreira Filho salienta que os candidatos a representantes do povo no Parlamento não exprimem de forma pura os seus ideais e planos, os quais refletem na realidade o plano dos partidos políticos, cuja existência e objetivo não se limitam unicamente a carrear mais votos para determinados candidatos. (FERREIRA FILHO, Manoel Gonçalves. Do Processo Legislativo. p. 87 e 266)

${ }^{128} \mathrm{O}$ mecanismo do voto de liderança está atualmente previsto no artigo 45 do Regimento Interno do Congresso Nacional. Tal mecanismo é de constitucionalidade duvidosa, como já demonstrou Sepulveda Pertence ao dar parecer pela inconstitucionalidade incidental de dispositivo do então vigente regimento interno do Congresso Nacional. (PERTENCE, José Paulo Sepulveda. Voto de Liderança. Revista de Direito Público, São Paulo, Revista dos Tribunais, v. 76, p. 57, out./dez. de 1985). Essa também é a opinião de Celso Ribeiro Bastos, fazendo referência a José Celso de Mello Filho (BASTOS, Celso Ribeiro; MARTINS, Ives Gandra. Comentários à Constituição do Brasil. $4^{\circ}$ Volume - tomo I. Arts. 44 a 69. São Paulo: Saraiva, 1995. p. 45-46).

${ }^{129}$ SILVA, José Afonso. Curso de Direito ..., p. 139.

130 "Ora, a partir do momento em que, por força da evolução constitucional (maxime da realidade constitucional), o executivo passou a ter por suporte a confiança do parlamento, a reserva dos impostos à lei
} 
Normalmente, tais situações ocorrem quando tratam de temas de comoção geral ou quando as forças políticas dentro do Congresso Nacional estão divididas, não se constatando a dominação de um partido político. Nesses casos, ainda que não se manifestando diariamente, o aspecto formal do princípio da legalidade demonstra a sua relevância, o que acarreta também a importância atual do voto e do processo legislativo.

Muito embora não se possa afirmar que a lei efetivamente expresse o consentimento do povo à tributação, fato é que, em algumas ocasiões, normalmente graves, é justamente o aspecto formal do princípio da legalidade que tem condições de proteger o contribuinte do Executivo. Daí a necessidade de eleger bons representantes no Congresso Nacional, que tenham a consciência da importância da sua função.

\section{I.D.3 Último Comentário sobre a Problemática da Legalidade Tributária}

Diante dos problemas dos aspectos material e formal acima comentados, não se pode negar que há uma certa flexibilização do princípio constitucional da legalidade tributária em seu aspecto material, bem como que, em alguns casos, há a violação desse princípio em seu aspecto formal.

No que toca ao aspecto material, a referida flexibilização não significa, observe-se bem, que houve uma atenuação da força do princípio da legalidade tributária, como forma de materialização da segurança jurídica e como meio de proteção da liberdade, como se explica abaixo.

A esse respeito, é importante observar que a força de contenção do princípio da legalidade tributária continua com a mesma intensidade quando há a possibilidade de utilização na lei de conceitos determinados, fechados. Por tal razão, o legislador deve, sempre que possível, adotar tais conceitos, já que são esses os que melhor atendem a segurança jurídica, proporcionando previsibilidade e certeza ao contribuinte (com melhor proteção, portanto, da liberdade). Nessa atividade, o legislador deve ter a cautela de não utilizar conceitos demasiadamente fechados, a fim de assegurar que a tributação seja

deixou de ter por função afastar estes da decisão de um órgão sem legitimidade democrática." (NABAIS, José Casalta. O Dever Fundamental de Pagar Impostos. Coimbra: Almedina, 2005. p. 330). 
instituída com respeito ao princípio da isonomia tributária. ${ }^{131}$ A força desse princípio também continua a mesma quando um tema é inteiramente tratado em lei, não havendo qualquer reenvio para a regulamentação.

No entanto, quando conceitos indeterminados são utilizados em lei (em virtude da natureza da própria linguagem ou da complexidade da vida econômica atual), daí a força desse princípio é ligeiramente atenuada diante do limite encontrado, exigindo-se então a participação do Chefe do Poder Executivo ou da Administração Tributária na fixação mais precisa da regra-matriz de incidência tributária. Nesse último caso, a função do regulamento passa a ser mais relevante, considerando que esse passa a esclarecer o critério de decisão estabelecido em lei. Dependendo do caso, o Executivo pode ser chamado, inclusive, a completar os conceitos indeterminados utilizados em lei, como ocorrido no caso da contribuição SAT, quando o regulamento não só esclarece o conceito utilizado em lei, mas também o precisa e o completa com base em dados da realidade. Há casos também em que a própria legislação deixa para o Executivo dispor acerca ou preencher algum aspecto relevante da lei tributária. São os casos de reenvios à regulamentação, como o exemplo da autorização conferida ao Executivo para reduzir e restabelecer as alíquotas do PIS e da COFINS sobre receitas financeiras no regime da não-cumulatividade.

Sob esse ângulo, o princípio da legalidade no sentido material sofre, portanto, uma certa flexibilização na atualidade.

Todavia, a flexibilização do princípio da legalidade material não significa que a força da segurança jurídica (como forma de proteção da liberdade) tenha sido diminuída no ordenamento jurídico, mas apenas e tão somente que a lei ordinária deixou de ter a mesma força de outrora para a concretização desse princípio/valor. Sob esse ângulo, a segurança jurídica passa a ser buscada e proporcionada não só pelo Poder Legislativo, como também pelo Poder Executivo e, principalmente, pelo Poder Judiciário. ${ }^{132}$

Nesse passo, dada a importância que o regulamento fiscal passa a ter na legislação tributária e, portanto, na implementação da segurança jurídica, o Chefe do Poder Executivo

${ }^{131}$ DOURADO, Ana Paula. O princípio da legalidade..., p. 156.

132 Sobre o mesmo problema, no âmbito do Direito Administrativo português, vide OTERO, Paulo. Legalidade e administração pública. p. 448-450. 
e a Administração Tributária devem passar a cumprir a função regulamentar com o maior zelo possível, não podendo exercer tal atribuição de forma arbitrária e opressora. ${ }^{133}$ Desse modo, e desde que a atividade regulamentar seja exercida de forma adequada, pode-se então afirmar que o próprio regulamento passa a ser, em conjunto com a lei ordinária, um meio de proteção da segurança jurídica e da liberdade do contribuinte.

É evidente que a concentração de poder nas mãos do Poder Executivo decorrente dessa realidade faz com que a atividade regulamentar necessite de um maior controle, sob risco de o Executivo não proporcionar a segurança jurídica e oprimir o contribuinte. Se a atividade regulamentar for conduzida de forma inadequada ou arbitrária (com extrapolação, distorção ou atropelamento da lei, de conceitos jurídicos, ou ainda com a violação de direitos fundamentais), o Poder Judiciário deverá agir com rigor, a fim de censurá-la imediatamente. Como bem salienta Eros Roberto Grau, "todos e quaisquer atos de aplicação de conceitos indeterminados [= juízos de legalidade] estão sujeitos ao exame e controle do Poder Judiciário."134 No caso de intervenção, o Poder Judiciário é quem dará a última palavra sobre o preciso sentido de um conceito indeterminado utilizado em lei. Apesar disso, o operador do Direito deve se atentar à problemática relativa aos limites do controle judicial quando o Executivo exercer uma atividade tipificante limitada, o que é abordado abaixo no Capítulo III (item III.C).

Como se pode perceber do acima exposto, a temática relativa à flexibilização do princípio da legalidade tributária, do dever do legislador e do Chefe do Poder Executivo de concretizar o princípio da legalidade tributária, em seu aspecto material, e da possibilidade de revisão das normas regulamentares editadas pela Administração Tributária pelo Poder Judiciário é um assunto que se relaciona não só com a questão do aspecto material do princípio da legalidade, mas também com a discussão sobre a tripartição de funções do Estado, razão pela qual será dedicado um capítulo para esse assunto.

\footnotetext{
${ }^{133}$ Ana Paula Dourado, ao estudar o princípio da legalidade tributária e as relações entre a lei formal e os regulamentos ou atos normativos com força de lei editados pelo Poder Executivo nos ordenamentos jurídicos de Portugal e Itália, defende que a previsibilidade buscada tradicionalmente pela lei formal passou a ser perseguida também por outros atos normativos expedidos pelo Poder Executivo. A autora nota a utilização de autorizações legislativas para o Executivo tratar de matéria tributária. Para a autora, o princípio da tipificação fiscal é supra-nacional, havendo um denominador comum entre vários ordenamentos jurídicos europeus, devendo, em qualquer caso, ser sempre guardada para a lei formal as grandes escolhas públicas sobre a tributação. (DOURADO, Ana Paula. O princípio da legalidade..., 214, 221 e 260).

${ }^{134}$ GRAU, Eros Roberto. Conceitos Indeterminados, p. 124.
} 
No que se refere ao aspecto formal do princípio da legalidade tributária, ainda que esse aspecto tenha sido desrespeitado algumas vezes e que a "lei" possa não exercer plenamente o seu papel quando o Executivo tem forte influência no Legislativo ou mesmo quando o mesmo partido político tem a maioria nos dois Poderes, há sempre a possibilidade de esse aspecto do princípio da legalidade ser relevante, seja diante do tema discutido, do momento político, ou mesmo em virtude da alternância do poder no regime democrático.

Além disso tudo, e muito embora não haja mais a obrigação de o tributo estar previsto na lei orçamentária para poder ser posteriormente exigido, a obrigação de previsão em lei para cobrança de tributos mantém, ainda que de forma mitigada se comparado com o antigo princípio da anualidade, uma relação de conexão que permite uma verificação de correspondência anual entre as receitas e despesas públicas pelo Congresso Nacional. ${ }^{135} \mathrm{~A}$ manutenção da exigência de lei formal para cobrança de tributo confere ao Congresso Nacional legitimidade para verificar se os tributos devem continuar a ser exigidos, se novos tributos devem ser instituídos e assegura ao órgão de representação popular uma autorização permanente de revisão do sistema tributário vigente e das despesas estatais, com a possibilidade de apresentação de propostas de revisão da legislação tributária, nos termos do parágrafo $2^{\circ}$ do artigo 165 da Constituição Federal.

\section{I.E O Princípio da Legalidade e as Obrigações Acessórias/Deveres Instrumentais}

As obrigações acessórias "tem por objeto as prestações, positivas ou negativas, nela previstas no interesse da arrecadação ou da fiscalização dos tributos". ${ }^{136}$ O mesmo dispositivo dispõe que as obrigações acessórias são estabelecidas pela legislação tributária.

A legislação tributária fixa mecanismos, sem conteúdo pecuniário, por meio dos quais são materializadas informações a respeito das atividades do contribuinte e do seu patrimônio que permitem à Administração Tributária controlar o nascimento, a vida e a extinção das obrigações tributárias principais. Para Paulo de Barros Carvalho, ${ }^{137}$ a

\footnotetext{
${ }^{135}$ No mesmo sentido, NABAIS, José Casalta. O Dever Fundamental de Pagar Impostos..., p. 340-343.

136 Artigo 113 do Código Tributário Nacional.

137 CARVALHO, Paulo de Barros. Curso de Direito Tributário..., p. 63 e seguintes, bem como 308 e seguintes. A expressão "deveres instrumentais" é mais apropriada, tendo em vista que há situações em que
} 
denominação mais apropriada de tais obrigações é a de deveres instrumentais, eis que pode haver ocasiões em que não há tributo devido, ou seja, em que não há obrigação principal com relação à qual o dever instrumental seria um acessório. Como exemplos de deveres instrumentais, cabe citar as inúmeras declarações que devem ser apresentadas ao fisco, os controles contábeis que o contribuinte deve manter, as obrigações de emissão de notas fiscais, recibos, dos conteúdos de tais documentos, etc.

Apesar de os deveres instrumentais não terem um conteúdo patrimonial em si, fato é que o seu cumprimento exige, na prática, o emprego de relevantes esforços pelo contribuinte, demandando pessoal especializado e dedicado, em caráter exclusivo, a atender às exigências formais da Administração Tributária. Adicionalmente, o descumprimento de tais deveres acarreta, via de regra, a imposição de sanções pecuniárias, podendo inclusive haver a configuração de crimes contra a ordem tributária, como estabelecido na Lei n. 8.137/90.

A obrigação de o contribuinte utilizar os referidos mecanismos de modo apropriado e proporcionar à Administração Tributária informações relevantes para fins fiscais constitui um "fazer" ou um "não-fazer" que, por tal razão, deve observar o princípio da legalidade genérica, previsto no artigo $5^{\circ}$, II da Constituição Federal, que assim dispõe: "ninguém será obrigado a fazer ou deixar de fazer alguma coisa senão em virtude de lei." Entretanto, o próprio artigo 113 do Código Tributário Nacional, que trata dos deveres instrumentais, utiliza a expressão "legislação tributária", conceito mais amplo que abarca também, ao lado da lei ordinária, outros veículos normativos, inclusive os atos normativos expedidos pela Administração Tributária.

Alguns autores entendem que deve haver uma lei ordinária específica para a instituição de deveres instrumentais de forma explícita em atenção ao princípio da legalidade, sob a luz do papel restrito do regulamento. ${ }^{138},{ }_{139},{ }^{140},{ }^{141}$ Outros autores

há a obrigação de cumprir os deveres instrumentais, mas não há a obrigação tributária principal, como nos casos de isenção.

${ }^{138}$ CARVALHO, Paulo de Barros. Curso de Direito Tributário..., p. 63.

139 CARRAZZA, Roque Antonio. O Regulamento no Direito Tributário Brasileiro. São Paulo: RT, 1981. p. 43-47.

${ }^{140}$ BALEEIRO, Aliomar. . Direito Tributário..., p. 702 e 709.

141 MARTINS, Ives Gandra da Silva. O Princípio da Legalidade no Direito Tributário Brasileiro. In: MARTINS. Ives Gandra da Silva____ (coord.) Caderno de Pesquisas Tributárias n. 6. Tema: Princípio da Legalidade. São Paulo: CEEU e Editora Resenha Tributária. 1981, p. 347 e seguintes. 
entendem que os deveres instrumentais não precisam, necessariamente, ser instituídos por lei específica, podendo tal instituição ocorrer de modo implícito na lei que trata do tributo em si. Para os últimos, apenas a imposição de multa pelo descumprimento dos deveres instrumentais é que estaria condicionada à existência de uma lei específica e prévia. $^{142,143,144}$ Ou seja, os últimos compreendem que a competência tributária conferida pela Constituição Federal combinada com a edição da lei sobre o tributo em si autoriza a instituição de deveres instrumentais pela regulamentação tributária, independentemente de uma lei específica.

José Souto Maior Borges ${ }^{145}$ observa que analisar os deveres instrumentais apenas a partir da forma do seu cumprimento empobrece a questão e dificulta a plena compreensão da figura jurídica em si. Para Borges, a obrigação acessória constitui um "dever" com um conteúdo específico que, muito embora não tenha um caráter pecuniário em si, não se distingue de uma obrigação. Tanto as normas que fixam a obrigação principal quanto aquelas que estabelecem o dever instrumental são válidas em um certo espaço e em um dado período de tempo, tendo ambas caráter transitório. Do mesmo modo que a obrigação principal, a obrigação acessória/dever instrumental implica um estado de sujeição, que deve ser observado pelo contribuinte e que acarreta a sua liberação após a sua satisfação. Daí decorre a conclusão de que a lei é necessária para a sua instituição.

Tendo em vista que a obrigação de cumprir um dever instrumental bem como de satisfazer a obrigação principal decorrem de normas jurídicas que fixam deveres para o contribuinte, pode-se concluir que a lei deve estabelecer a estrutura básica desse dever, que deve ser detalhado na regulamentação tributária, o que permite a interpretação harmônica do artigo $5^{\circ}$, II da Constituição Federal e das disposições do Código Tributário Nacional sobre a matéria. ${ }^{146}$ Como o descumprimento de um dever instrumental acarreta penalidades e pode configurar crime, é fundamental que a estrutura básica do dever

\footnotetext{
${ }^{142}$ XAVIER, Alberto. Os Princípios da Legalidade e da Tipicidade... p. 32-33.

${ }^{143}$ OLIVEIRA, Ricardo Mariz. Princípios da Legalidade. In: MARTINS, Ives Gandra (coord.) Caderno de Pesquisas Tributárias n. 6. Tema: Princípio da Legalidade. São Paulo: CEEU e Editora Resenha Tributária, 1981. p. 403.

144 PAULSEN, Leandro. Direito Tributário: Constituição e Código Tributário à Luz da Doutrina e da Jurisprudência. 6. ed. rev. atual. Porto Alegre: Livraria do Advogado: ESMAFE, 2004.

${ }^{145}$ BORGES, José Souto Maior. Obrigação Tributária (Uma Introdução Metodológica). 2. ed. São Paulo: Malheiros, 1999. p. 46 e seguintes.

${ }^{146}$ No mesmo sentido, vide BOLAN, Ricardo Ferreira. O Papel da Lei na Criação de Deveres Instrumentais Tributários. Revista Direito Tributário Atual do Instituto Brasileiro de Direito Tributário, São Paulo: Editora Dialética, n. 17, p. 302, 2003.
} 
instrumental seja fixada em lei, como forma de proteção da liberdade e da segurança jurídica. Da mesma forma, é fora de dúvida que a penalidade pelo descumprimento de obrigação acessória deve ser fixada em lei.

Não obstante, alguns recentes julgados do Superior Tribunal de Justiça indicam uma tendência de permitir que a regulamentação tributária institua deveres instrumentais independente de lei, já que a própria previsão legal de tributação ou de exoneração de uma atividade permitiria, implícita ou indiretamente, a instituição dos deveres instrumentais respectivos. Verifica-se aqui também uma flexibilização do princípio da legalidade genérica. São os Recursos em Mandado de Segurança n. 21789-MS e 27476-MS, julgados pela Primeira Turma, em unanimidade, em outubro de 2006 e em novembro de 2008, respectivamente.

Considerando que esse tema envolve o artigo $5^{\circ}$, II da Carta Magna, o Supremo Tribunal Federal deverá se manifestar sobre o mesmo, quando ficarão claros os limites entre a lei e a regulamentação fiscal para fins de instituição dos deveres instrumentais. ${ }^{147}$

Nessas circunstâncias, verifica-se que, também no campo dos deveres instrumentais, a regulamentação tributária está passando a ter um papel mais relevante diante da lei, com uma maior concentração de poder no Executivo, o que demanda um controle maior desse. Do mesmo modo, também aqui há uma discussão relativa ao desempenho das funções dos Poderes Legislativo, Executivo e Judiciário na fixação dos deveres instrumentais.

\footnotetext{
${ }^{147}$ No caso envolvendo o Recurso em Mandado de Segurança n. 21789-MS, já houve o trânsito em julgado, mas, no do Recurso n. 27476-MS, o contribuinte interpôs, em fevereiro de 2009, recurso extraordinário.
} 


\section{CAPítulo II - A REgUlamentaÇÃo tributária E A "NORMA ESPELHO"}

\section{II.A Delimitação do Conceito de Regulamentação Tributária}

Tendo em vista que o processo estudado no presente trabalho pode ser aplicado na edição de regulamentos em sentido estrito (como aqueles editados com base no artigo 84, IV da Constituição Federal) e de outras normas infralegais tributárias, será utilizado o conceito de "regulamento" em sentido lato, com a finalidade de alcançar qualquer ato normativo infralegal que regulamente a legislação tributária, tais como os próprios regulamentos, as instruções normativas, as decisões normativas, as portarias, etc. Por isso, referir-se-á à "regulamentação tributária” em geral.

A razão da adoção dessa abordagem está ligada ao fato de o Chefe do Poder Executivo e a Administração Tributária regulamentarem, na prática, temas tributários por meio de diferentes instrumentos normativos, inclusive por meio de normas que, a princípio, não deveriam afetar o contribuinte (como, por exemplo, as portarias). Entretanto, como todos esses instrumentos normativos podem implicar a adoção uniforme de interpretações ou posições da Administração Tributária em detrimento direto ou indireto do contribuinte, todos eles são considerados, indistintamente, como integrantes da regulamentação tributária. ${ }^{148,149,150}$ Os casos concretos comentados ao final deste capítulo evidenciam a utilização de diferentes espécies de normas infralegais que afetaram diretamente o contribuinte, fora o regulamento em sentido estrito.

\footnotetext{
${ }^{148} \mathrm{O}$ paralelo com as instruções ministeriais também é feito por Geraldo Ataliba, com o reconhecimento do notável efeito didático desse paralelo. Decreto Regulamentar.... p. 28.

${ }^{149}$ Os comentários de Giuseppe Melis acerca das alterações das interpretações da administração tributária italiana sobre um mesmo tema, veiculadas por meio das circolares (de efeito meramente interno da administração), demonstram que também naquele país o contribuinte pode ser afetado por atos normativos do fisco que, a princípio, não deveriam produzir efeitos sobre ele. O autor reporta que as modificações da posição da Administração Tributária veiculadas pelas circolares desencadearam importantes estudos de boafé e de tutela do contribuinte diante de contradições do fisco, bem como jurisprudência acerca da impossibilidade de se atribuir efeitos retroativos a uma nova interpretação do fisco prejudicial ao contribuinte. (MELIS, Giuseppe. L'Interpretazione nel Diritto Tributario. Padova: CEDAM, 2003. p. 519 e seguintes).

${ }^{150}$ Augusto Fantozzi também reconhece que, na Itália, é difícil distinguir em alguns casos o conteúdo dos regulamentos e das circolares, mas defende a importância da distinção desses atos normativos. (FANTOZZI, Augusto. Corso di Diritto Tributario. Torino: UTET, 2005. p. 57).
} 
Dessa maneira, estão incluídos no conceito de "regulamentação tributária" o regulamento em sentido estrito e os atos administrativos normativos da Administração Tributária com atributos normativos, ou seja, que tenham caráter deôntico, constituindo um "dever-ser" que afete o contribuinte, com os traços de abstração, generalidade e impessoalidade, mas sem a capacidade de inovar o ordenamento jurídico, em consonância com o princípio do primado da lei (artigo 84, IV da Constituição Federal e artigo 99 do Código Tributário Nacional). ${ }^{151}$ Tais atos devem ser dotados de publicidade, para que o contribuinte possa conhecê-los.

Não se incluem nesse conceito as normas regulamentares de organização interna da Administração Tributária que não afetam a liberdade e a esfera patrimonial do contribuinte. Tais normas visam a acomodar o aparelho administrativo, permitindo a observação da lei pela Administração Tributária. ${ }^{152} \mathrm{Na}$ hipótese de essas normas contrariarem ou indiretamente criarem ônus indevidos ao contribuinte, elas também deverão então ser consideradas como regulamentação tributária para fins do presente trabalho.

Não estão incluídos no conceito de regulamentação tributária ora adotado os atos concretos e individuais, nem os atos puramente adjudicatórios.

Independente de toda a regulamentação tributária poder se sujeitar ao mesmo processo de produção normativa discutido no presente trabalho, não se pode olvidar que o operador do Direito deve sempre ter atenção à natureza jurídica do veículo normativo utilizado, considerando que pode haver implicações jurídicas importantes. Por exemplo, enquanto o regulamento editado pelo Presidente da República deve observar os termos da lei e é oponível ao contribuinte dentro de seus limites, uma instrução deve respeitar a lei e o próprio regulamento, não sendo a princípio diretamente oponível ao contribuinte. ${ }^{153}$

\footnotetext{
${ }^{151}$ O conceito de "inovar a ordem jurídica" não é unívoco. Cabe mencionar as palavras de Celso Antônio Bandeira de Mello: "E inovar quer dizer introduzir algo cuja preexistência não se pode conclusivamente deduzir da lei regulamentada." (MELlO, Celso Antônio B. Curso de Direito Administrativo. 17. ed. São Paulo: Malheiros, 2004. p. 326).

${ }^{152}$ ATALIBA, Geraldo. Decreto Regulamentar..., p. 23.

${ }^{153}$ Roque Antonio Carrazza afirma que a edição de portarias e instruções da Receita Federal do Brasil não refletem o exercício de competência regulamentar, constituindo meras manifestações da chamada "atividade administrativa interna" (CARRAZZA, Roque Antonio. O Princípio da Legalidade e a Faculdade Regulamentar no Direito Tributário. In: TORRES, Heleno (coord.). Tratado de Direito Constitucional Tributário: Estudos em Homenagem a Paulo de Barros Carvalho. São Paulo: Saraiva, 2005. p. 531.). No mesmo sentido, Heleno Torres afirma que instrução normativa não pode regulamentar lei (TORRES, Heleno.
} 
Do mesmo modo, enquanto o regulamento em sentido estrito é tecnicamente apto a, em determinados casos, completar conceitos indeterminados utilizados em lei ordinária que fixa a regra-matriz de incidência tributária (com o preenchimento de conceitos utilizados pela lei), as demais normas regulamentares, em contraste, apenas expressam uma interpretação da Administração Tributária, não sendo capazes de completar a legislação. No entanto, cabe salientar que existem situações em sentido contrário na prática, como é o caso da fixação da margem de valor agregado de ICMS por meio de portarias no Estado de São Paulo.

\section{II.B Fundamento do Poder Regulamentar}

A fundamentação do poder regulamentar na esfera tributária encontra-se na lei editada por pessoa política com competência legislativa para legislar sobre o tributo respectivo. Ataliba explica que, por exigência constitucional, o poder regulamentar somente pode ser exercido a partir do momento em que a lei tributária é editada. ${ }^{154}$ Sem lei prévia, não há que se falar em poder regulamentar. Em outras palavras, o poder regulamentar depende da lei, sendo antes da sua edição uma mera potencialidade. ${ }^{155}$

Mas não basta qualquer lei prévia para embasar o poder regulamentar. É necessário que a referida lei seja editada por pessoa política com competência legislativa constitucional para tratar do assunto. Sem competência legislativa constitucional, não existe lei prévia apta a ensejar o exercício legítimo do poder regulamentar tributário. $\mathrm{O}$

Conflitos de Fontes e de Normas no Direito Tributário - O Princípio da Segurança Jurídica na Formação da Obrigação Tributária. In: TORRES, Heleno (coord.) Teoria Geral da Obrigação Tributária: Estudos em Homenagem ao Professor Souto Maior Borges. São Paulo: Malheiros, 2005. p. 155.). Muito embora essas posições sejam corretas da perspectiva teórica ao exigir o regulamento editado pelo Chefe do Poder Executivo, a Administração Tributária utiliza, na prática, os mais diversos instrumentos normativos secundários para regulamentar matérias sensíveis ao contribuinte, razão pela qual se incluem no mesmo conceito de "regulamentação tributária" ora adotado todas as referidas espécies de regulamentação. Não se despreza a hierarquia entre essas normas, mas elas são incluídas no conceito de "regulamentação tributária", considerando que todas elas podem ser melhoradas por meio da participação do contribuinte no processo de sua edição.

${ }^{154}$ ATALIBA, Geraldo. Decreto Regulamentar..., p. 24.

155 “Afinal, só por lei se regulam liberdade e propriedade; só por lei se impõem obrigações de fazer e não fazer; e só para cumprir dispositivos legais é que o Executivo pode expedir decretos, regulamentos e, $a$ fortiori, atos de menor hierarquia, como as resoluções." (MELLO, Celso Antônio Bandeira. Lei e Regulamento - A Chamada "Reserva de Lei" - As Delegações Legislativas Disfarçadas. Revista Trimestral de Direito Público, São Paulo, Malheiros, v. 49-50, p. 9, 2005.) 
fundamento do poder regulamentar vai então além da lei, abrangendo a Constituição Federal. $^{156}$

Nesse passo, o Presidente da República pode regulamentar as leis tributárias de competência da União Federal, como o imposto de renda, mas jamais uma lei que trate do imposto municipal sobre serviços.

Dito isso, cabe observar que o fundamento lógico e subjacente do poder de expedir regulamentos em sentido estrito é a necessidade de o Executivo aplicar a lei previamente editada pelo Poder Legislativo de forma isonômica e eficiente; é o dever de agir inerente à função executiva (atribuição originária). ${ }^{157},{ }^{158}$ Trata-se do primeiro ato de execução da lei, que é exercido em abstrato. Sem regulamentar a lei, a atividade executiva pode se tornar complicada e não uniforme, especialmente quando se tem em mente a necessidade de fiscalizar o cumprimento da legislação tributária em massa. Não se trata de um "poder" ou de uma "faculdade"; há, isso sim, um genuíno dever de regulamentar, em observação aos princípios da igualdade e da eficiência, razão pela qual a própria Constituição Federal, no artigo 84, IV, não faz alusão a um "poder", mas sim a uma "atribuição", a uma função. Logo, tal dispositivo constitui uma norma de competência impositiva.

O fundamento do poder de editar regulamentos em sentido lato é, a nosso ver, o mesmo da atribuição de expedir regulamentos em sentido estrito. Tendo em vista que a lei deve ser aplicada pelos funcionários da Administração Tributária, nada mais natural que o fundamento desse poder seja o mesmo do poder regulamentar em sentido estrito, qual seja: a obrigação de o Poder Executivo se organizar melhor para aplicar a lei de forma eficiente e isonômica. Como salientado acima, muitos regulamentos em sentido lato acabam sendo

\footnotetext{
${ }^{156}$ Sergio Ferraz comenta as diferentes teorias a respeito do fundamento do poder regulamentar, apontando três especificamente, quais sejam: (i) da consideração do poder regulamentar como uma concretização do poder discricionário inerente à função administrativa, teoria essa criticada pelo fato de deixar a Administração Pública com maior margem de liberdade e de não refletir a realidade, que mostra a importância da lei prévia para o poder regulamentar; (ii) do entendimento do poder regulamentar como decorrente de uma delegação legislativa, criticada por colocar no mesmo patamar lei e regulamento e por esbarrar no princípio da separação de poderes; e (iii) da identificação do fundamento do poder regulamentar na lei ou na constituição, que Ferraz aceita mas considera insuficiente. Para Ferraz, essa última teoria é admissível se for reconhecido que, em alguns casos, o poder regulamentar possa ser exercido a partir do texto constitucional, afirmando que existem duas espécies de regulamento: o regrado e o discricionário. (FERRAZ, Sergio. Regulamento. In: SANTOS, J.M. de Carvalho (coord.) Repertório Enciclopédico do Direito Brasileiro. Rio de Janeiro: Editor Borsoi, 1972, p. 48-49)

${ }^{157}$ FERRAZ, op. cit., p. 49.
} 
diretamente editados diante da lei, independentemente de prévia publicação de um regulamento em sentido estrito, o qual deveria a rigor existir também como seu fundamento. ${ }^{159}$

\section{II.C Dever de Editar Regulamentação Tributária}

Encontra-se na doutrina posição no sentido de que certas leis seriam autoexecutáveis, esgotando a matéria legislada, caso no qual não caberia regulamentação ou a regulamentação produzida seria ilegal e inconstitucional. ${ }^{160}$ Por outro lado, no que toca às chamadas leis não autoaplicáveis, estas sim dependem de regulamentação, hipótese na qual existiria um genuíno "dever-poder” de regulamentar.

Nesse particular, cumpre ressaltar que pode haver discussão acerca da qualificação de uma lei como autoaplicável ou não autoaplicável, situação na qual se estará debatendo, de forma subjacente, acerca da existência ou não do dever regulamentar do Poder Executivo, ou seja, sobre a natureza impositiva da competência regulamentar atribuída a esse poder. Essa é uma questão de interpretação que deveria ter a sua importância devidamente reconhecida pelos operadores do Direito e pelo próprio Poder Judiciário, pois o Executivo não pode se omitir diante da obrigação de regulamentar uma lei para permitir a melhor compreensão dessa e a forma da sua aplicação, proporcionando maior segurança jurídica para o contribuinte.

Da mesma forma, nos casos em que a própria legislação condiciona ao regulamento o exercício de direitos conferidos em lei ao contribuinte (reenvio à regulamentação), o Chefe do Poder Executivo e a Administração Tributária têm o dever de regulamentar a lei

\footnotetext{
${ }^{158}$ GASPARINI, Diogenes. Poder Regulamentar. 2. ed. São Paulo: Editora Revista dos Tribunais, 1982. p. 27.

${ }^{159}$ Heleno Torres critica a utilização de instruções normativas do Secretário da Receita Federal do Brasil para regulamentação de temas que deveriam ser veiculados por meio de decreto presidencial, em vista de indicação expressa ao Presidente da República na Carta Maior. Nesses casos, o fundamento da instrução normativa encontra-se no decreto presidencial, cujos fundamento são, por sua vez, a lei e a Constituição Federal. (TORRES, Heleno Taveira. Imposto de Importação e o Acordo de Valoração Aduaneira. Ajustes do Valor de Transação com Royalties e Serviços. In: TORRES, Heleno (coord.) Direito Tributário Internacional Aplicado. Volume II. São Paulo: Quartier Latin, 2004. p. 197-198).

${ }^{160}$ ATALIBA, Geraldo. Decreto Regulamentar..., p. 24.
} 
em prazo razoável, ${ }^{161}$ a fim de permitir o exercício dos direitos atribuídos pela lei. A omissão, em prejuízo do contribuinte, é inadmissível. ${ }^{162}$

Quando a lei ordinária pretender condicionar o exercício de um direito à regulamentação tributária, o Poder Legislativo deve sempre ter em mente, quando da edição da lei, que o Chefe do Executivo ou a Administração Tributária pode simplesmente ignorar a lei ou deixá-la de lado, a fim de impedir ou retardar o exercício do direito pelo contribuinte. Como forma de combater o risco dessa inversão hierárquica de normas e permitir a efetividade da lei, o Legislativo deve incluir na lei ordinária comandos que obriguem a edição de regulamentação pela Administração Tributária dentro de um determinado prazo, sob pena de se permitir o exercício do direito do contribuinte, independentemente da regulamentação. ${ }^{163}$

Tanto no caso dos regulamentos em sentido estrito quanto com relação aos demais atos infralegais, o dever de regulamentar é qualificado, devendo ser exercido de forma impessoal, moral, eficiente e pública, nos termos da lei, como rezam os artigos 37, 84, IV e 150, I da Carta Magna.

É importante notar que o exercício do dever de regulamentar é, a rigor, mais complicado do que o de legislar. ${ }^{164},{ }^{165} \mathrm{O}$ exercício do poder legislativo com o objetivo de editar uma nova lei deve levar em conta a Constituição Federal, as leis existentes e os tratados internacionais aplicáveis ao caso. O exercício do dever de regulamentar deve observar a lei nova, as outras leis existentes, a própria Constituição Federal e tratados aplicáveis (e ainda, em alguns casos, outros regulamentos e o regulamento anterior inclusive). Ademais, a atividade de regulamentar pressupõe um conhecimento mais técnico e detalhista acerca da matéria regulamentada, devendo estar mais próximo da realidade. Dependendo da situação, como no caso do SAT, por exemplo, a atividade regulamentar envolve também a colheita de dados em concreto e o preenchimento de padrões fixados em lei (constituindo uma atividade de certa forma tipificadora, dentro dos

\footnotetext{
${ }^{161}$ GASPARINI, Diógenes. Poder..., p. 19.

${ }^{162}$ CARRAZZA, Roque Antonio. O Princípio da Legalidade e a Faculdade Regulamentar..., p. 530.

163 Vide os comentários de Clèmerson Merlin Clève sobre o princípio da autonomia da lei diante do regulamento e acerca do princípio da colaboração necessária entre lei e regulamento. CLÈVE, Clémerson Merlin. Atividade legislativa..., p. 290.

${ }^{164}$ MIRANDA, Pontes. Comentários à Constituição de 1967. Com a Emenda n. 1, de 1969. Tomo III (Arts. 32-117). Rio de Janeiro: Forense, 1987. p. 314.
} 
padrões da lei), o que exige interação com o contribuinte e a tomada de uma decisão diante dos dados concretos colhidos.

Para a regulamentação tributária cumprir os seus objetivos, essa precisa ser dotada de maior precisão, abordando uma situação intermediária entre os extremos da abstração da lei e da concretude inerente à aplicação da lei em um caso específico. Muito embora a regulamentação tributária não contenha a solução de um caso individual (ou seja, não constitua a decisão propriamente dita, quando há a conjugação da norma com os fatos concretos), ela constitui a ligação, a "ponte" entre a lei abstrata e o caso concreto, esclarecendo e explicitando o conteúdo da lei, ${ }^{166}$ bem como balizando o comportamento dos agentes da Administração Tributária. ${ }^{167}$ Por esse motivo, o poder de editar a regulamentação tributária deve ser exercido com o objetivo de tentar construir um espelho a partir do qual a norma aplicável a um caso específico constituirá um reflexo, do que decorre a necessidade de antever na regulamentação, em caráter hipotético, tanto os casos simples como os casos mais complexos. ${ }^{168}$

A mera repetição do conteúdo da lei na regulamentação tributária é conduta condenável e inútil, que nada contribui para proporcionar maior segurança jurídica. No mesmo sentido, a regulamentação pobre e superficial tem pouco valor e deve ser evitada.

Além disso, na regulamentação, deve haver o detalhamento dos deveres instrumentais exigidos (e.g., elaboração dos modelos/programas de declarações, etc.), o que é necessário para tratar, de maneira efetiva, da forma de aplicação da lei.

\section{II.D Teste de Harmonia da Regulamentação Tributária / Construção da "Norma Espelho"}

A partir do momento de edição da regulamentação tributária, as normas infralegais editadas passam a integrar o ordenamento jurídico e a comportar interpretação, seja pelo

\footnotetext{
${ }^{165}$ CARRAZZA, Roque Antonio. O Regulamento..., p. 115, nota de rodapé 99.

${ }^{166}$ CARRAZZA, Roque. O Regulamento..., p. 17.

${ }^{167}$ MELLO, Celso Antônio Bandeira. Curso de Direito Administrativo..., p. 330.

${ }^{168}$ A utilização de exemplos de casos complexos na regulamentação, sem serem exaustivos, não é prática corrente no Brasil, mas poderiam ser certamente úteis em alguns casos. Os antigos pareceres normativos da Receita Federal do Brasil constituem prova dessa utilidade. Nos Estados Unidos, os regulamentos
} 
contribuinte, por acadêmicos, pelo Poder Judiciário, pelo Ministério Público, pelos tribunais administrativos ou mesmo pelos demais membros integrantes da Administração Tributária, em fiscalizações, em respostas a consultas, etc. Em outras palavras, após a sua edição, os próprios regulamentos permitem diferentes interpretações e a construção de distintas normas a partir do mesmo texto escrito.

É nesse momento que o contribuinte e as pessoas referidas acima realizam um teste de harmonia da regulamentação diante da lei e do ordenamento jurídico como um todo, para fins de conhecimento da norma jurídica em abstrato ou de sua aplicação em um caso específico. Para a realização de tal teste, é necessário construir a norma de decisão que constitui, nas palavras de David Duarte, um espelho aplicável a fatos hipotéticos (a "norma espelho"), contendo o significado da norma jurídica, expresso de forma mais densa. ${ }^{169,170}$

A "norma espelho" constitui uma norma da ciência do Direito que permite a solução de casos em caráter genérico com base em fatos hipotéticos, não estando limitada às peculiaridades de um caso específico. Ela constitui uma ferramenta para o operador do Direito, que fica apto a avaliar se a regulamentação tributária está em conformidade com a lei e com o ordenamento jurídico como um todo. É ela que revela ao contribuinte se algum abuso foi cometido no exercício da atribuição regulamentar.

Apesar de conter a mesma estrutura de uma norma jurídica (antecedente, operador deôntico e consequente), a "norma espelho" constitui uma explicação do Direito, estando fora do ordenamento jurídico. A "norma espelho" não constitui um "dever-ser", a não ser que seja reconhecida como um costume, considerado uma prática reiteradamente observada pelas autoridades administrativas, nos termos do artigo 100, III do Código Tributário Nacional.

(regulations) do Internal Revenue Code contêm exemplos em muitos casos para facilitar a compreensão da matéria.

169 “A norma de decisão é formulada, então, como um espelho da norma aplicável, reproduzindo a norma e acrescentando a generalização de factos, nos termos descritos, daí resultando uma norma com uma estrutura em tudo idêntica à das normas do conjunto normativo: tem, por isso, os mesmos elementos estruturais, a (i) previsão, o (ii) operador deôntico e a (iii) estatuição." Note-se que o autor chama de "norma de decisão" tanto a norma abstrata e genérica quanto a solução jurídica de um caso específico. A norma de decisão é objeto da ciência do direito, não compondo o ordenamento jurídico. (DUARTE, David. A Norma de Legalidade Procedimental Administrativa. A Teoria da Norma e a Criação de Normas de Decisão na Discricionariedade Instrutória. Coimbra: Almedina, 2006. p. 165, 190 e 192).

${ }^{170}$ Adota-se, no presente trabalho, o termo "norma espelho" para se evitar a confusão com a "norma de decisão" enquanto solução jurídica de um caso concreto. 
$\mathrm{Na}$ área tributária, a prática de se construir a partir dos textos do ordenamento jurídico uma norma e de conjugá-la com fatos hipotéticos, de tal sorte a se criar uma solução geral em abstrato, aplicável a casos repetitivos concretos, nada mais é do que a construção da "norma espelho", estudada como uma ferramenta por David Duarte de forma organizada e consciente.

A construção da "norma espelho" demanda três etapas, quais sejam: ${ }^{171}$ (i) a determinação semântica; (ii) a individualização normativa, com a solução de concorrências e conflitos normativos; e (iii) o reconhecimento de uma norma residual, que serve de solução de casos não resolvidos nas etapas anteriores. A solução de um caso concreto pode estar em qualquer uma das referidas etapas.

Comentam-se, brevemente, abaixo, as referidas etapas.

\section{II.D.1 Determinação Semântica}

A determinação semântica na construção da "norma espelho" nada mais é do que interpretação. Assim, a determinação semântica constitui o exercício de produzir a norma, que se encontra em estado de potência no texto, ${ }^{172}$ a ser aplicada em vários casos.

Nessa atividade, o operador do Direito se depara com questões relativas à compreensão da norma, envolvendo conceitos ambíguos e indeterminados, já abordados no Capítulo I, ao qual fazemos referência.

Assim, na construção da "norma espelho", o intérprete deve respeitar as zonas de certeza positiva e negativa dos conceitos indeterminados utilizados em lei, sendo que, com relação aos casos duvidosos, inseridos na zona de penumbra, o cuidado deve ser redobrado para que se capte o sentido efetivo da norma. ${ }^{173}$ Devem ser observados os conceitos utilizados na Constituição Federal, bem como aqueles utilizados no direito privado, em fiel respeito aos artigos 109 e 110 do Código Tributário Nacional. Não podem ser utilizados

\footnotetext{
${ }^{171}$ DUARTE, David. A Norma de Legalidade..., p. 161 e seguintes.

${ }^{172}$ GRAU, Eros Roberto. Ensaio e Discurso sobre a Interpretação..., p. 28

173 IZELLI, Anna Flávia de Azevedo. Limites à Interpretação e Aplicação de Conceitos Jurídicos Indeterminados..., p. 173 e seguintes.
} 
conceitos econômicos ou de outras ciências, que não a jurídica. $\mathrm{Na}$ atividade interpretativa, o operador do Direito deve empregar diferentes métodos de interpretação, tais como o método gramatical, sistemático, lógico e histórico. ${ }^{174}$

A etapa de determinação semântica engloba também a análise sintática e pragmática. Nesse passo, a norma deve fazer um sentido específico para o intérprete sob os três ângulos da Semiótica, permitindo, assim, a construção da "norma espelho".

Após essa etapa, o intérprete deve verificar como a norma construída até esse momento se insere no ordenamento jurídico, a fim de confirmá-la ou ajustá-la para produzir, finalmente, a "norma espelho".

\section{II.D.2 Individualização Normativa}

Como é amplamente estudado em Direito, o sistema jurídico deve ser interpretado como um todo, e não em tiras. ${ }^{175}$ Dessa maneira, não pode a "norma espelho" ser produzida única e exclusivamente com base na lei regulamentada, sob risco de produção de uma ferramenta inconsistente com outras leis ou até mesmo com a Constituição Federal.

Como relatado no Capítulo I, pode haver antinomias no sistema jurídico, bem como conflitos entre regras e princípios e colisões entre princípios. As antinomias podem ser resolvidas com base nos critérios de especialidade e cronológico para normas de mesma estatura, e hierárquico para normas de diferente nível. No caso de não se tratar de antinomia, mas sim de normas contraditórias baseadas em princípios em tensão, o operador do Direito deverá ponderar qual delas deverá ser considerada como apta a integrar a "norma espelho", sendo, então, a norma capaz de ser aplicável a um caso concreto posteriormente.

\footnotetext{
174 Esse problema existe também no Direito Administrativo: "Pode dizer-se que se a resolução das antinomias jurídicas é tarefa complexa, a sua prevenção não se mostra fácil, revelando todo um protagonismo da Administração Pública na definição ou redefinição do sentido interpretativo da legalidade administrativa que, sem prejuízo de sempre estar sujeito a controlo judicial, faz dos órgãos administrativos operadores activos no recorte do sentido da estrutura normativa vinculativa da sua própria actuação no exercício da função administrativa.” (OTERO, Paulo. Legalidade e administração pública. p. 650).

${ }^{175}$ GRAU, Eros Roberto. Ensaio e Discurso sobre a Interpretação... p. 40, 127-128.
} 
Ainda a esse respeito, não se pode deixar de comentar que a posição de que a regulamentação tributária está vinculada única e exclusivamente à lei a ser regulamentada deve ser considerada com cautela, ${ }^{176}$ caso contrário a regulamentação assim produzida potencialmente colidirá com a "norma espelho". Com efeito, como salientado no Capítulo I, deve-se buscar a unidade e a coerência do sistema jurídico como um todo, de tal sorte que haja um arranjo pleno e organizado entre as diferentes normas existentes. Tanto na regulamentação de uma lei como na produção da "norma espelho", deve-se levar em conta todo o ordenamento jurídico, inclusive a Constituição Federal e os tratados internacionais celebrados pela República Federativa do Brasil sobre matéria tributária.

Com relação aos deveres introduzidos pela lei, a Administração Tributária está, de fato, vinculada à lei a ser regulamentada, mas, no que toca aos direitos fundamentais, ela deve observar todo o sistema jurídico e ter certeza de que tais direitos são respeitados, medida essa que, se não observada, potencializa conflitos com a "norma espelho", ${ }^{177,178}$ e, naturalmente, litígios.

A obrigação de levar em conta o ordenamento jurídico como um todo na construção da "norma espelho" constitui medida de proteção dos direitos fundamentais, que busca

\footnotetext{
176 Essa interpretação, todavia, não é geralmente aceita pelos tribunais administrativos pátrios, que se consideram obrigados a aplicar a lei, independente de questões constitucionais e sem analisar se há ou não a violação de direitos fundamentais protegidos constitucionalmente. O artigo 49 do antigo Regimento Interno dos Conselhos de Contribuintes dispunha que: "No julgamento de recurso voluntário ou de ofício, fica vedado aos Conselhos de Contribuintes afastar a aplicação ou deixar de observar tratado, acordo internacional, lei ou decreto, sob fundamento de inconstitucionalidade." No mesmo sentido, a Súmula n. 02 do antigo Primeiro Conselho de Contribuintes estabelece que: "O Primeiro Conselho de Contribuintes não é competente para se pronunciar sobre a inconstitucionalidade de lei tributária".

177 "Por seu turno, no respeitante ao significado normativo dos preceitos constitucionais relativos aos deveres fundamentais para a administração e os particulares, não há grande coisa a acrescentar ao que já foi dito. Pois, quanto à administração, pela sua própria natureza de poder subordinado à lei (ordinária) e de seu executor, está impedida de aplicar directamente a constituição, o que deriva da própria constituição que, por um lado, prescreve o princípio da legalidade da administração e, por outro, estabelece como única excepção a tal princípio a aplicabilidade directa pela administração dos preceitos constitucionais relativos aos direitos, liberdades e garantias. Donde facilmente se conclui que a administração só pode aplicar os preceitos constitucionais respeitantes aos deveres fundamentais nos termos e na medida da lei. (...).” (NABAIS, José Casalta. O Dever Fundamental..., p. 162).

${ }^{178} \mathrm{O}$ mesmo vale para o Direito Administrativo português. "Todo o estudo efectuado em torno da exacta determinação do grau de vinculação administrativa ao critério hierárquico de resolução de antinomias normativas permitiu extrair que, salvo no que diz respeito principalmente aos conflitos que envolvem normas violadoras do cerne da dignidade da pessoa humana, certas violações da Constituição formal ou tratando-se de normas internas que se opõem a determinadas normas do Direito Comunitário, os órgãos administrativos não se encontram habilitados genericamente a desaplicar normas com fundamento na sua invalidade por contrariarem outras que lhes são hierarquicamente superiores, razão pela qual o critério hierárquico exerce uma clara função excepcional na solução de antinomias normativas pela Administração Pública.” (OTERO, Paulo. Legalidade e Administração Pública. p. 696)
} 
identificar não apenas os casos de inconstitucionalidade evidente, mas sim os casos mais sutis e, portanto, mais perigosos ao contribuinte.

\section{II.D.3 Norma Residual}

A "norma espelho" construída com base nas etapas anteriores pode ainda não estar apta a resolver certos casos, como quando a norma construída possui efeitos alternativos ou constitui uma permissão. ${ }^{179}$ Nessas situações, o intérprete deve adicionar aos fatos hipotéticos outros elementos fáticos também hipotéticos, de tal sorte a permitir a construção da "norma espelho".

Como abordado anteriormente, cada operador do Direito constrói a sua própria "norma espelho" e a utiliza como ferramenta para verificar se a regulamentação tributária editada está em consonância ou não com o ordenamento jurídico. Apesar de a "norma espelho" não constituir uma norma jurídica, a "norma espelho" é utilizada como meio revelador da norma jurídica efetiva (e, portanto, de proteção do contribuinte), sendo que o confronto dessa com a regulamentação tributária expõe as falhas cometidas na edição de tal regulamentação, servindo de subsídio para o debate tributário, como os exemplos comentados ao final deste capítulo demonstram.

\section{II.E Tipos de Regulamento (Regulamentação Tributária)}

Como se expõe a seguir, a doutrina estuda e classifica os regulamentos em sentido estrito. As classificações dos tipos de regulamentos em sentido estrito são plenamente aplicáveis aos demais atos normativos de regulamentação tributária, tendo em vista que todos esses atos constituem instrumentos normativos secundários dentro do ordenamento jurídico, sem a capacidade de inovar a ordem jurídica.

Diógenes Gasparini ${ }^{180}$ esclarece que os regulamentos podem ser classificados, com relação aos seus destinatários, como gerais ou especiais. Enquanto os gerais alcançam todos os particulares que se encontrem em uma dada situação, os especiais afetam apenas

\footnotetext{
${ }^{179}$ DUARTE, David. A Norma de Legalidade..., p. 320 e seguintes.

${ }^{180}$ GASPARINI, Diógenes. Poder Regulamentar, p. 41 e seguintes.
} 
um limitado grupo de particulares, que se colocam em uma situação de maior sujeição diante da Administração Pública.

Esse autor também distingue os regulamentos com relação à extensão dos seus efeitos, classificando-os em: (i) os de caráter nacional, aplicáveis em todo o território do país; e (ii) os de cunho regional, destinados a regiões especiais, como os aplicáveis no Nordeste.

Outra classificação adotada pelo autor é aquela que leva em conta a autoridade ou órgão que o editou, podendo classificar os regulamentos em federal, estadual, municipal ou do Distrito Federal.

Os regulamentos também podem ser classificados como internos ou externos. Os regulamentos internos só devem vincular os quadros da Administração Pública, hipótese na qual há uma maior liberdade do regulamento diante da lei e a possibilidade de delegação do poder de sua edição. Normalmente, são regulamentos que tratam de temas de organização interna da administração. Os regulamentos externos, por sua vez, afetam terceiros e devem prestar respeito à lei. O poder de edição dos regulamentos externos (em sentido estrito), que podem vincular terceiros, é indelegável.

Ainda na doutrina, os regulamentos são geralmente classificados em autônomos (também chamados de independentes), delegados (ou autorizados), de necessidade (ou de urgência) e de execução, ${ }^{181,182,183,184,185,186}$ dependendo da relação estabelecida entre o regulamento e a lei.

Os regulamentos autônomos comportam normas não previamente reguladas em lei, em caráter praeter legem, para preencher o espaço vazio da lei. Tais regulamentos podem até mesmo elaborar contra legem. ${ }^{187}$ Tais regulamentos não são, tradicionalmente, admitidos no Brasil, mas, mais recentemente, eles passaram a ser aceitos, em caráter

\footnotetext{
${ }^{181}$ CARRAZZA, Roque Antonio. O Regulamento..., p. 11 (nota 19).

${ }^{182}$ FERRAZ, Sergio. Regulamento, p. 47 e seguintes.

${ }^{183}$ LEAL, Victor Nunes. Lei e Regulamento. Revista de Direito Administrativo n. 1, p. 388 e seguintes.

${ }^{184}$ VELLOSO, Carlos Mário da Silva. Do Poder Regulamentar..., p. 42.

${ }^{185}$ CLÈVE, Clèmerson Merlin. Atividade legislativa..., p. 291 e seguintes.

${ }^{186}$ Eros Roberto Grau defende que os regulamentos existentes no Brasil são os seguintes: (i) de execução; (ii) autorizados; e (iii) autônomos ou independentes. (GRAU, Eros Roberto. O Direito Posto..., p. 253.)
} 
excepcional, para a regulamentação de questões de organização e funcionamento interno da Administração Pública federal, quando não há aumento de despesas nem criação ou extinção de órgãos, conforme o artigo 84, VI, "a" da Constituição Federal. ${ }^{188}$ No Direito Tributário pátrio, tais regulamentos não são aceitos, em sintonia com o princípio da legalidade tributária.

Os regulamentos de necessidade ou de urgência, por sua vez, são aqueles editados em situações graves (guerra, calamidade pública, etc.) que justificam a sua edição imediata, sem a necessidade de submeter a matéria regulamentada ao processo legislativo, mais moroso por natureza. Tratam-se de manifestações políticas que só adquirem legitimidade depois de convalidadas em lei, conforme a ordem jurídica vigente. Também não são admitidos no nosso Direito Tributário.

Já os regulamentos delegados são regulamentos editados pelo Poder Executivo em virtude de autorização conferida pelo Poder Legislativo. Esses regulamentos tratam de matéria que normalmente seria regulada em lei, mas em razão de determinação do Poder Legislativo a competência para tratar da matéria é expressamente delegada ao Poder Executivo. ${ }^{189}$ Dada a importância da autorização conferida pelo Poder Legislativo para o Executivo regular uma dada matéria, o preâmbulo desse regulamento deve fazer referência específica ao dispositivo legal que instituiu a delegação.

Os regulamentos delegados não são aceitos no nosso sistema tributário, mas o já comentado artigo 27 da Lei n. 10865/2004 parece exatamente estabelecer uma delegação para a Administração Tributária.

No que toca aos regulamentos de execução, esses sim são instrumentos normativos secundários que viabilizam a aplicação da lei, detalhando e explicitando de forma pormenorizada os seus comandos e os seus conceitos. Esses regulamentos estão

\footnotetext{
${ }^{187}$ VELLOSO, Carlos Mário da Silva. Do Poder Regulamentar..., p. 42.

${ }^{188} \mathrm{Na}$ Constituição Federal de 1967 (art. 81, V), admitia-se o regulamento autônomo para dispor sobre a estruturação, atribuições e funcionamento dos órgãos da administração pública federal, mas essa possibilidade foi eliminada com a exigência de lei no artigo 84, VI da Constituição Federal de 1988. Com a Emenda Constitucional 32/2001, deixou de ser exigida a lei para tratar de tais atribuições, quando a alteração não implicar aumento de despesa nem criação ou extinção de órgãos públicos, ou seja, voltou-se a admitir a possibilidade de regulamento autônomo sobre tais matérias em algumas hipóteses. Trata-se de caso específico e isolado, interno à Administração Pública.

${ }^{189}$ FERRAZ, Sergio. Regulamento, p. 53.
} 
vinculados à lei e devem observá-la de forma fiel (secundum legem), não comportando conteúdo contra legem, praeter legem, ultra legem e extra legem. Esse tipo de regulamento é admitido no Direito Tributário nacional, de acordo com o artigo 84, IV da Constituição Federal atual e com o artigo 99 do Código Tributário Nacional.

A fim de permitir a fiel aplicação da lei tributária, esses regulamentos podem tratar de aspectos meramente mecânicos da Administração Tributária (código de recolhimento, programa de declaração, formulários, etc.), bem como de questões mais importantes, relativas à melhor compreensão dos conceitos, inclusive indeterminados, utilizados em lei. Nesse particular, cabe referência ao breve estudo conduzido acerca dos conceitos indeterminados no Capítulo I, bem como a respeito da inexistência de discricionariedade ou discricionariedade técnica na sua regulamentação.

Frise-se que, no regulamento intra legem, o Ministro Carlos Mário Velloso reconheceu no voto proferido no julgamento do caso SAT que tal regulamento não reflete uma delegação pura, como se depreende do seguinte trecho:

nesses casos, a lei, fixando parâmetros e padrões, comete ao regulamento essa aferição. Não há falar, em casos assim, em delegação pura, que é ofensiva ao princípio da legalidade genérica (C.F., art. $5^{\circ}$, II) e da legalidade tributária (C.F., art. 150, I). ${ }^{190}$

Desse modo, o Ministro Carlos Velloso reconheceu que o regulamento intra legem é uma espécie de regulamento de execução, no qual o Poder Executivo pode não só esclarecer e desdobrar o conteúdo da lei, como também preenchê-lo com base em dados da realidade.

Nesse passo, não é apropriado falar em delegação quando o poder regulamentar decorre da utilização de conceitos indeterminados em lei, posto que o Poder Executivo tem o dever de não só respeitar tais padrões, como também de aplicá-los da melhor forma, de tal maneira que o regulamento editado ao final esteja em conformidade com a lei e com o ordenamento jurídico como um todo. Para que não haja uma delegação violadora da legalidade fiscal, os referidos padrões contidos em conceitos indeterminados na lei devem

${ }^{190}$ Fls. 1404 e 1405 dos autos do processo. 
ter uma densidade mínima, caso contrário haverá uma inversão hierárquica, como examinado no Capítulo I.

Antes de prosseguir, cabe verificar alguns casos examinados pelo Supremo Tribunal Federal a respeito da possibilidade de o Poder Executivo editar regulamentação intra legem, na qual são trabalhados dados da realidade para preencher os conceitos indeterminados contidos na lei e, assim, completar a lei tributária. O objetivo dessa análise é demonstrar, uma vez mais, o papel relevante da regulamentação tributária na atualidade, conforme a jurisprudência do Supremo.

\section{II.E.1 Regulamentação Tributária Intra Legem em Litígio no Supremo Tribunal Federal}

O Supremo Tribunal Federal já teve oportunidade para verificar a compatibilidade da regulamentação tributária intra legem, com a colheita de dados da realidade, com o princípio da legalidade tributária no ordenamento jurídico nacional.

Aborda-se, abaixo, jurisprudência de nossa corte superior sobre o tema.

\section{II.E.1.1. Caso do Valor Venal - Base de Cálculo do IPTU}

Em 1979, o Plenário do Supremo Tribunal Federal julgou o recurso extraordinário n. 87.763-1, no qual foi decidido que a majoração do valor venal para fins de cálculo do imposto sobre a propriedade predial e territorial urbana ("IPTU") somente pode ser realizada por meio de lei, resguardando o direito do Poder Executivo municipal de ajuste do valor venal do imóvel anualmente por meio de índice oficial de correção monetária.

Muito embora a determinação de o valor venal de um imóvel ser atividade inerente à função executiva, exigindo a colheita de dados concretos, as Administrações Tributárias municipais não realizavam tal determinação, o que acarretava a transformação da base de cálculo do IPTU em uma presunção, como explica Misabel de Abreu Machado Derzi. ${ }^{191}$

${ }^{191}$ DERZI, Misabel de Abreu Machado. Direito tributário, direito penal..., p. 344 e seguintes. 
Além disso, o IPTU foi majorado em alguns municípios em mais de cinco mil por cento, surpreendendo milhares de contribuintes, em clara quebra de confiança.

Nesse cenário, o Supremo Tribunal Federal não aceitou que a Administração Tributária municipal determinasse o valor venal dos imóveis com base em dados da realidade, tendo em vista que essa atividade simplesmente não era realizada diante de cada imóvel, mas era, isso sim, substituída por uma atividade tipificante livre de padrões fixados em lei. Assim, a Administração Tributária estabelecia o valor venal por uma média, violando o comando legal de que o IPTU deveria ser cobrado com base no valor venal de cada imóvel.

O efeito desse julgamento é que a majoração do valor venal de imóveis para fins de cobrança do IPTU somente pode ser realizada por meio de lei, o que não significa que o Poder Executivo municipal determine, de forma isolada e efetiva, o valor venal de cada imóvel para que o Legislativo o aprove. A tributação ocorre então pela média encontrada, de sorte que a tipificação ocorre em nível legal, e não regulamentar.

Em um caso isolado envolvendo o Município de Belo Horizonte (recurso extraordinário n. 108.774-9, julgado em 1988), o Plenário do Supremo Tribunal Federal aceitou que o valor venal fosse determinado pelo Poder Executivo municipal, já que a lei do IPTU, além de fixar a base de cálculo como o valor venal, trazia critérios para determinação desse valor in concreto. Posteriormente, outros julgamentos do Supremo envolvendo o Município de Belo Horizonte exigiram a aprovação da planta genérica, com os valores venais, em lei (e.g., Ag. Reg. no Agravo de Instrumento n. 592.184-1, em 2008), seguindo a orientação do precedente firmado no julgamento do recurso extraordinário n. 87.763-1.

\section{II.E.1.2. Caso da Taxa de Fiscalização Ambiental}

Em março de 2000, o Supremo Tribunal Federal reconheceu a inconstitucionalidade da taxa de fiscalização ambiental ("TFA") instituída pela Lei n. 9.960/2000 (ADI $2178 \mathrm{MC} / \mathrm{DF}){ }^{192}$

\footnotetext{
${ }^{192}$ MARTINS, Ives Gandra da Silva. A Taxa de Controle e Fiscalização Ambiental - TCFA. In: TORRES, Heleno Taveira (coord.) Direito Tributário Ambiental. São Paulo: Malheiros, 2005. p.749.
} 
Nesse julgamento, o Tribunal reconheceu a existência de três inconstitucionalidades, quais sejam: (a) a definição do fato gerador da taxa como sendo a atividade conduzida pelo contribuinte, e não o exercício do poder de polícia; (b) a ausência de fixação em lei das pessoas físicas ou jurídicas potencialmente poluidoras ou utilizadoras de recursos ambientais, cuja definição teria sido atribuída à regulamentação (definição do sujeito passivo); e (c) a estipulação de montantes uniformes da taxa a forfeit por classe de contribuintes, com violação ao princípio da isonomia tributária.

No que toca à questão da regulamentação propriamente dita em conexão com a identificação do sujeito passivo da TFA, o Tribunal não admitiu que a Administração Tributária utilizasse o Cadastro Técnico Federal de Atividades Potencialmente Poluidoras ou Utilizadoras de Recursos Ambientais ${ }^{193}$ para fins de fixação do contribuinte do tributo. O artigo 17, II da Lei n. 6938/81 (com alterações posteriores), instituía o referido cadastro para o fim de registrar as pessoas físicas ou jurídicas que se dedicam a atividade potencialmente poluidoras elou à extração, produção, transporte e comercialização de produtos potencialmente perigosos ao meio ambiente, assim como de produtos e subprodutos da fauna e flora.

Frise-se, por fim, que a questão da violação ao princípio da legalidade tributária foi uma entre outras inconstitucionalidades examinadas e reconhecidas pelo Tribunal, ${ }^{194}$ não tendo sido uma questão analisada de forma isolada.

\section{II.E.1.3 Caso dos Semi-Elaborados - Incidência de ICMS}

Posteriormente, em junho de 2000, o Plenário do Supremo decidiu que a atribuição da Lei Complementar n. 65/91 ao Conselho Nacional de Política Fazendária (CONFAZ) da função de "elaborar lista dos produtos industrializados semi-elaborados segundo definidos

\footnotetext{
${ }^{193}$ Nos termos do parágrafo $2^{\circ}$ do artigo 17-B da Lei n. 6938/81, com a redação dada pela Lei n. 9960/2000 "são sujeitos passivos da TFA, as pessoas físicas ou jurídicas obrigadas ao registro no Cadastro Técnico Federal de Atividades Potencialmente Poluidoras ou Utilizadoras de Recursos Ambientais."

${ }^{194}$ Ao analisar isoladamente a questão da identificação do sujeito passivo, Ricardo Lobo Torres entende que a Lei n. 9960/2000 era constitucional nesse ponto. Para Torres, "se o cadastro era válido para deflagrar a fiscalização preventiva do IBAMA, porque nele estavam inscritos os potenciais poluidores, não vemos porque não possa servir de base à nova tributação." (TORRES, Ricardo Lobo. Interação entre Princípios Constitucionais Tributários e Princípios da Ordem Econômica. In: FERRAZ, Roberto (coord.) Princípios e
} 
no artigo anterior, atualizando-a sempre que necessário" não constituía delegação de poder legislativo, em violação ao parágrafo primeiro do artigo 68 da Constituição Federal. Por isso, a exigência do ICMS sobre os produtos constantes de tal lista foi considerada como legítima (recurso extraordinário n. 240.186-1-PE).

Considerando a permanente evolução do parque industrial, a referida lei complementar introduziu, em seu artigo primeiro, o conceito dos produtos industrializados semi-elaborados e, no artigo segundo, além de atribuir ao CONFAZ a função de elaborar a lista de referidos produtos, obrigou tal órgão a atualizar a referida lista sempre que necessário. Portanto, a Lei Complementar n. 65/91 estabeleceu o conceito de produtos industrializados semi-elaborados, o que constituiu a referência para a lista a ser elaborada pelo CONFAZ com base em dados concretos.

Nesse caso, a regulamentação tributária foi aceita como uma regulamentação intra legem, tendo o Supremo Tribunal Federal entendido que a Administração Tributária apenas deu maior precisão a um conceito indeterminado utilizado em lei (nessa situação, lei complementar) com base em informações concretas.

Ainda nesse julgamento, e como não poderia ser diferente, o Supremo Tribunal Federal apenas examinou a constitucionalidade da possibilidade de o CONFAZ listar os produtos industrializados semi-elaborados para fins de ICMS, não se debruçando sobre a análise jurídica e técnica realizada por esse órgão no preenchimento do padrão fixado em lei. Vale transcrever trecho do acórdão nesse sentido:

Assim, a tributação do açúcar demerara, neste caso, poderia ter sido impugnada sob eventual alegação de não se enquadrar o produto na definição do artigo primeiro da lei complementar sob enfoque; nunca, entretanto, por não haver sido por ela relacionado como sujeito ao ICMS, ou por havê-lo sido em instrumento normativo inadequado. ${ }^{195}$

\section{II.E.1.4 Caso da Substituição Tributária - Margem de Valor Agregado - ICMS}

Limites da Tributação 2 - Os Princípios da Ordem Econômica e a Tributação. São Paulo: Quartier Latin, 2009. p. 513).

${ }^{195}$ Fls. 465 dos autos. 
No ano de 2002, o Plenário do Supremo Tribunal Federal reconheceu como constitucional a substituição tributária de ICMS para frente, tendo admitido a determinação de uma parcela da base de cálculo do ICMS nesse regime (margem de valor agregado) por meio de um "critério de estimativa que a aproxima o mais possível da realidade" (Ação Direta de Inconstitucionalidade n. 1.851-4 Alagoas).

Apesar de essa não ser a questão central em discussão nesse julgamento, pode-se afirmar que o Tribunal aceitou que a "margem de valor agregado", que compõe a base de cálculo do ICMS na substituição tributária, seja fixada pela Administração Tributária com base em dados da realidade, sob a luz de critérios fixados em lei, conforme estipula o parágrafo $4^{\circ}$ do artigo $8^{\circ}$ da Lei Complementar n. 87/96.

O Ministro Marco Aurelio salientou, inclusive, a sua preocupação acerca da fixação unilateral da margem de valor agregado pela Administração Tributária estadual.

\section{II.E.1.5 Caso SAT}

Sobre esse caso, julgado em 2003, fazemos referência aos nossos comentários constantes do Capítulo I. Como salientado, o Plenário da nossa Corte Suprema decidiu que não há violação ao princípio da legalidade tributária na edição de regulamento intra legem que permite ao Poder Executivo completar, em regulamento e com base em dados concretos, os conceitos de "atividade preponderante" e "grau de risco leve, médio e grave", constantes da lei ordinária.

Do mesmo modo que no caso dos semi-elaborados, e como não poderia ser diferente, o Tribunal não examinou a atividade jurídica e técnica da Administração Tributária de qualificar a atividade do contribuinte como sujeita a um risco leve, médio ou grave. Assim restou o acórdão:

agora, se o regulamento foi além da lei - e na verdade é isto o que se alega - a questão não é de inconstitucionalidade. Se verdadeira a alegação, ter-se-ia questão de ilegalidade, que não integra o contencioso constitucional e que, bem por isso, não autoriza admissão do recurso extraordinário, restrito ao contencioso constitucional. ${ }^{196}$

\footnotetext{
${ }^{196}$ Fls. 1410 dos autos.
} 


\section{II.E.1.6. Comentário Analítico}

Os casos dos semi-elaborados e da margem de valor agregado no ICMS, bem como do SAT indicam uma tendência de o Supremo Tribunal Federal não reconhecer uma violação ao princípio da legalidade tributária no caso de edição de regulamentação tributária intra legem, que demande a coleta, a análise e a decisão acerca de dados concretos, apesar de essa atividade ter consequências sérias para o contribuinte. Tais casos também deixam claro que o poder regulamentar da Administração Tributária não se limita à automática e mecânica execução da lei em um raciocínio subsuntivo puro, sendo possível a complementação de conceitos indeterminados utilizados em lei, com a verificação de dados em concreto, o que constitui uma atividade tipificadora limitada, dentro dos padrões fixados em lei.

Tais julgamentos evidenciam, portanto, uma tendência de flexibilização do princípio da legalidade tributária.

Não obstante, essa tendência não significa que o poder regulamentar possa ser exercido de qualquer maneira. Muito pelo contrário. A atribuição regulamentar deve ser exercida nos termos da lei, sob pena de se caracterizar uma ilegalidade ou inconstitucionalidade passível de censura pelo Poder Judiciário.

A maior importância conferida pelo Supremo Tribunal Federal à regulamentação tributária para precisar conceitos indeterminados constantes da lei, inclusive com a colheita de dados em concreto, não equivale a um "cheque em branco" entregue à Administração Tributária para regular a exigência de tributos da forma como lhe convier; mas constitui, isso sim, uma ordem específica para cobrar os tributos nos termos dos conceitos indeterminados utilizados em lei e com respeito aos direitos fundamentais do contribuinte. Exatamente por isso é que se pode afirmar que também a regulamentação tributária deve trabalhar para proporcionar segurança jurídica.

Logo, a flexibilização da legalidade tributária, por si só e em tese, não constitui uma violação aos direitos fundamentais do contribuinte ou um enfraquecimento do Estado de Direito brasileiro. Tal flexibilização não reflete uma violação automática aos direitos de 
liberdade, propriedade, igualdade do contribuinte, mas sim uma mitigação da força da lei como mecanismo de garantia de tais direitos fundamentais.

O raciocínio é que os limites inerentes à lei a impedem de proporcionar a segurança jurídica de forma plena, sendo que a regulamentação tributária também fica incumbida de trabalhar para proporcionar previsibilidade jurídica. ${ }^{197}$ Sob esse ângulo, a segurança jurídica é reconhecida como um meio de garantia dos direitos fundamentais do contribuinte, ${ }^{198}$ e não como um direito em si próprio.

Na trilha desse raciocínio, a edição per se de regulamentação tributária intra legem não é suficiente para caracterizar uma inconstitucionalidade em virtude de violação ao princípio da legalidade tributária, sendo necessário demonstrar a violação a direitos fundamentais dentro do conteúdo específico e concreto de uma regulamentação.

Dessa forma, em razão da sua própria jurisprudência, desenvolvida em uma realidade altamente complexa, o Supremo Tribunal Federal assumiu uma responsabilidade prospectiva com relação à produção futura da regulamentação físcal pela Administração Tributária, que deverá respeitar os direitos fundamentais e as limitações constitucionais assegurados pela Constituição Federal. ${ }^{199}$

\footnotetext{
${ }^{197}$ Nesse mesmo sentido, Ana Paula Dourado defende que não se pode invocar a tipicidade (garantia) como meio de fundamentação da própria legalidade (liberdade), aceitando que a tipicidade possa ser alcançada em nível regulamentar. (DOURADO, Ana Paula. O princípio da legalidade..., p. 319 e seguintes e 766).

${ }^{198}$ A segurança jurídica deixa então de ser estática na lei, tornando-se dinâmica e alcançando de forma mais intensa a regulamentação, em virtude de esta última estar mais próxima da realidade. São esclarecedores os comentários de Carlos Alberto Alvaro de Oliveira sobre a segurança jurídica, sob a luz do processo civil: "Observo, em primeiro lugar, que a mudança de paradigma decorrente da passagem do normativismo legalista para o direito fundamental principiológico afeta igualmente a segurança jurídica, que deixa de ser estática, na medida em que passa a conviver com um direito muito mais flexível e menos rígido. De tal forma, hoje a segurança jurídica de uma norma deve ser medida pela estabilidade de sua finalidade, abrangida em caso de necessidade por seu próprio movimento. Não mais se busca o absoluto da segurança jurídica, mas a segurança jurídica afetada de um coeficiente, de uma garantia da realidade. (...) Em suma, a segurança já não é vista com os olhos do Estado liberal, em que tendia a prevalecer como valor, porque não serve mais aos fins sociais a que o Estado se destina. Dentro dessas coordenadas, o aplicador deve estar atento às peculiaridades do caso, pois, às vezes, mesmo atendido o formalismo estabelecido pelo sistema, em face das circunstâncias da espécie, o processo pode se apresentar injusto ou conduzir a um resultado injusto." (OLIVEIRA, Carlos Alberto Alvaro. Os Direitos Fundamentais à Efetividade e à Segurança em Perspectiva Dinâmica. In: SALLES, Carlos Alberto (coord.) As Grandes Transformações do Processo Civil Brasileiro: Homenagem ao Professor Kazuo Watanabe. São Paulo: Editora Quartier Latin, 2009. p. 43).

199 "A transformação dessas condições, com o advento da sociedade tecnológica e do estado social, parece desenvolver exigências no sentido de uma desneutralização, posto que o juiz é chamado a exercer uma função socioterapêutica, liberando-se do apertado condicionamento da estrita legalidade e da responsabilidade exclusivamente retrospectiva que ela impõe, obrigando-se a uma responsabilidade prospectiva, preocupada com a consecução de finalidades políticas das quais ele não mais se exime em nome do princípio da legalidade (dura lex sed lex). (...) A responsabilidade do juiz alcança agora a responsabilidade
} 
Nesse passo, se determinado Estado da federação fixa, por exemplo, a margem de valor agregado do ICMS em percentual alto, em total descompasso com a realidade, a ponto de caracterizar um efeito confiscatório, a Corte Suprema pátria deverá intervir diante de reclamação do contribuinte, para protegê-lo.

O caso do valor venal no IPTU, cuja orientação continua sendo observada na jurisprudência do Supremo Tribunal Federal, indica que se a atribuição regulamentar for exercida de forma abusiva pela Administração Tributária, com violações aos direitos fundamentais do contribuinte, daí a violação ao princípio da legalidade tributária restará caracterizada. Nessas situações, o contribuinte continuará tendo acesso ao Tribunal constitucional. Essa também é a observação que se pode extrair do caso da TFA: quando houver uma série de violações aos direitos fundamentais do contribuinte, daí a inconstitucionalidade será reconhecida e o Tribunal poderá determinar que um assunto, que seria naturalmente matéria de regulamento, seja objeto de lei.

Os casos complicados serão aqueles em que a Administração Tributária exercer a atribuição regulamentar de forma inadequada, mas nos quais as distorções não forem flagrantes a ponto de permitir o pronto reconhecimento de uma ilegalidade ou inconstitucionalidade. Exatamente nesses casos é que o contribuinte merecerá maior atenção do Poder Judiciário, visto que a conduta da Administração Tributária terá a aparência de ter sido conduzida dentro dos padrões legais, mas no fundo será violadora do ordenamento jurídico.

Feitos esses comentários, cumpre ressaltar que toda a atividade de regulamentação tributária conduzida pela Administração Tributária está sujeita ao controle do Poder Judiciário, seja quando tal atividade apenas precise e explicite melhor os conceitos indeterminados utilizados em lei, quando referida atividade regulamente tema fundamental para aplicação da lei (caso de reenvio) ou ainda quando dita atividade também envolva a

pelo sucesso político das finalidades impostas aos demais poderes pelas exigências do estado social. Ou seja, como o Legislativo e o Executivo, o Judiciário torna-se responsável pela coerência de suas atitudes em conformidade com os projetos de mudança social, postulando-se que eventuais insucessos de suas decisões devem ser corrigidos pelo próprio processo judicial.” (FERRAZ JR., Tércio Sampaio. O Judiciário Frente à Divisão dos Poderes: um Princípio em Decadência? Revista Trimestral de Direito Público, São Paulo, Malheiros, 9 , p. 45, 1995.) 
coleta de dados da realidade para preencher tais conceitos. Poderão ser analisadas questões de constitucionalidade e de legalidade da regulamentação tributária.

Tendo em vista o histórico da relação fisco/contribuinte no Brasil, é fora de dúvida que essa nova realidade expõe o contribuinte a maiores riscos diante da atividade normativa da Administração Tributária. Entretanto, não parece que essa realidade se alterará no futuro breve, o que demanda novos mecanismos jurídicos de controle do fisco.

Os exemplos concretos comentados abaixo comprovam esses riscos.

\section{II.F Crítica à Regulamentação Tributária - Casos Concretos}

A fim de demonstrar a necessidade de melhora da qualidade e da forma de exercício do poder regulamentar tributário, são explorados aqui alguns casos concretos que evidenciam falhas no exercício da atribuição regulamentar pela Administração Tributária.

Inicia-se com um caso de omissão, em que o regulamento competente não foi editado, abordando-se então um caso em que houve indevida inovação da ordem jurídica pela regulamentação tributária (instrução normativa) e, finalmente, um exemplo em que o exercício do poder regulamentar foi exercido de forma não transparente (portaria).

\section{II.F.1 Omissão na Edição da Regulamentação Tributária - Caso da Exclusão das Receitas de Terceiros da Base de Cálculo do PIS/COFINS}

Antes da sua revogação, o inciso III do parágrafo $2^{\circ}$ do artigo $3^{\circ}$ da Lei $n$. 9718/98 200 condicionava ao regulamento a exclusão da base de cálculo do PIS/COFINS de valores computados como receita própria e transferidos para terceiros. Ou seja, desde que regulamento instituísse a forma de controle, o contribuinte poderia segregar os elementos formadores de sua receita própria, com o escopo de identificar os valores a serem transferidos para terceiros, receitas desses últimos, para fins de exclusão da base de cálculo do PIS/COFINS do contribuinte. Parecia se tratar de norma que buscava, em 1998,

200 “Art. $3^{\circ}$. (...) Parágrafo $2^{\circ}$ Para fins de determinação da base de cálculo das contribuições a que se refere o art. $2^{\circ}$, excluem-se da receita bruta: (...) III - os valores que, computados como receita, tenham sido transferidos para outra pessoa jurídica, observadas normas regulamentadoras expedidas pelo Poder Executivo." 
neutralizar o efeito cumulativo das referidas contribuições, que já era então muito criticado.

Como se pode perceber desse dispositivo legal, tratava-se de típico caso de lei não autoaplicável que atribuiu um direito ao contribuinte que reduziria o seu ônus fiscal com relação ao PIS/COFINS. Apesar disso, houve omissão do Poder Executivo, não tendo sido cumprido o dever de regulamentar o mencionado dispositivo da Lei n. 9718/98, em prejuízo do contribuinte.

A omissão do Poder Executivo levou o tema a ser objeto de discussão no Poder Judiciário. Diante de casos específicos sobre o assunto, o Superior Tribunal de Justiça não reconheceu o direito do contribuinte à exclusão prevista no artigo $3^{\circ}$, parágrafo $2^{\circ}$, inciso III da Lei n. 9718/98, tendo decidido que a norma era de eficácia contida e que não poderia ser aplicada sem regulamentação, de sorte que o Legislativo teria dado liberdade ao Executivo para tratar livremente do tema. ${ }^{201}$ Os seguintes acórdãos foram proferidos pelo Superior Tribunal de Justiça nesse sentido: REsp 445.452 (17.12.2002 - Primeira Turma unanimidade); REsp 512.232/RS (07.10.2003 - Primeira Turma - unanimidade); AgRg no Agravo de Instrumento 586.885/SC (02.12.2004 - Primeira Turma - unanimidade) e REsp 529.745 (19.02.2004 - Segunda Turma - unanimidade). ${ }^{202}$

Nos casos acima referidos, não foi argumentada, nos recursos extraordinários interpostos perante o Supremo Tribunal Federal, a violação ao artigo 84, IV da Constituição Federal em razão da omissão do Poder Executivo, o que deveria desencadear a aplicação plena do artigo $3^{\circ}$, paragráfo $2^{\circ}$, inciso III da Lei n. 9718/98 independentemente da edição do regulamento. A análise do conteúdo do referido dispositivo constitucional pelo Supremo Tribunal Federal nessa disputa constituiria um importante precedente para confirmar que a atribuição regulamentar constitui um genuíno dever jurídico, uma norma de competência impositiva, e não uma mera faculdade que pode ser exercida com base em juízo de conveniência e oportunidade.

\footnotetext{
201 “A questão que se coloca é a seguinte: o comando legal era auto-executável, podendo produzir efeitos imediatos, sob pena de violação do princípio da legalidade? Creio que não, na medida em que a exclusão estava subordinada a uma condição de aplicabilidade, sem limite temporal, deixando o legislador que o Executivo agisse livremente." (Resp n. 502.263-RS - 16.09.2003 - Segunda Turma - unanimidade - voto do relator)
} 
Note-se que esse argumento foi corretamente adotado, por exemplo, no voto proferido pelo Desembargador Federal Dirceu de Almeida Soares, do Tribunal Regional Federal da $4^{\mathrm{a}}$ Região, no julgamento da Apelação em Mandado de Segurança n. 2002.70.05.000882-0/PR (22.10.2002 - Segunda Turma - unanimidade), nos seguintes termos:

Desta forma, o regulamento a ser expedido pelo Poder Executivo para possibilitar a aplicação do art. $3^{\circ}$, parágrafo $2^{\circ}$, III, da Lei n. 9.718, de 1998, não poderá contrariar o referido dispositivo, apenas explicitá-lo. Sendo assim, entendo que o contribuinte não pode sofrer prejuízos em face da ausência de regulamentação do dispositivo em questão, razão pela qual é possível deduzir da receita bruta, para fins de determinação da base de cálculo da contribuição, os valores que, computados como receita, foram transferidos a outras pessoas jurídicas.

Como se pode perceber, a regulamentação tributária não cumpriu o seu papel diante do artigo $3^{\circ}$, parágrafo $2^{\circ}$, III da Lei n. 9718/98, não permitindo que o comando legal produzisse os efeitos fiscais almejados pelo Congresso Nacional. Nesse particular, não se pode negar que o próprio Poder Legislativo falhou também, pois este poderia ter instituído um prazo para o Poder Executivo exercer o seu dever de regulamentar, sob pena de o direito de exclusão instituído ser aplicado de forma plena pelo contribuinte após o decurso de tal prazo. Da mesma forma, o Poder Judiciário também não resolveu a questão da melhor forma porque acabou atribuindo maior importância ao regulamento, ou melhor, à sua ausência do que à própria lei ordinária, em clara subversão hierárquica que acarretou o esvaziamento completo da lei.

\section{II.F.2 Indevida Inovação da Ordem Jurídica - Caso da Alteração da Fórmula do PRL 60\% em Instrução Normativa}

Lamentavelmente, inúmeros são os casos em que o Executivo extrapola os termos da lei na regulamentação fiscal, com a indevida inovação da ordem jurídica, em atividade claramente inconstitucional. A jurisprudência do STF é prova disso. Não se pretende explorar a fundo casos nesse sentido, mas apenas citar um exemplo como forma de demonstração da problemática, que continua a existir na atualidade.

${ }^{202}$ Luís Eduardo Schoueri também tratou do tema. (SCHOUERI, L. E. A Suave Perda da Liberdade-..., p. 8.) 
A Lei n. 9430/96 introduziu as regras de preços de transferência no Brasil, as quais têm como objetivo o combate à prática de transferir lucros não tributados no Brasil para pessoas vinculadas estabelecidas em outras jurisdições, prática essa que se materializa por meio da manipulação de preços em operações de importação ou exportação de bens, serviços ou direitos.

Em linhas gerais, o meio utilizado para alcançar o objetivo acima é a comparação entre o preço praticado na operação e o preço apurado segundo as regras de preços de transferência, comumente referido como preço parâmetro. Caso haja uma disparidade material entre o preço praticado e o preço parâmetro, as regras determinam a tributação da diferença apurada.

Nas importações, um dos métodos estabelecidos pela legislação para teste dos preços praticados entre pessoas vinculadas é o método do preço de revenda menos lucro ("PRL").

Na redação original do artigo 18 da Lei n. 9430/96, a margem de lucro no PRL foi fixada em 20\% (vinte por cento). Posteriormente, a Lei n. 9959/2000 alterou a redação do referido dispositivo e estabeleceu duas margens de lucro, quais sejam: (i) 60\% (sessenta por cento), calculada sobre o preço de revenda após deduzidos os valores especificamente permitidos na lei (descontos incondicionais, comissões, etc.) e o valor agregado no país, para o caso de bens aplicados à produção; e (ii) 20\% (vinte por cento), determinada sobre o preço de revenda, aplicável às demais hipóteses.

No entanto, o parágrafo 11 do artigo 12 da Instrução Normativa n. 243/2002 estabeleceu uma fórmula para cálculo do PRL aplicável ao caso de bens importados utilizados na produção que distorce os termos da lei. A aplicação da metodologia estabelecida na norma infralegal acarreta um resultado prejudicial ao contribuinte em contraste com a forma de cálculo do preço parâmetro de acordo com os termos da Lei n. 9430/96. A metodologia regulamentar força o contribuinte a determinar um preço parâmetro inferior na importação, de tal sorte que uma parcela maior do preço praticado na importação passa a ser indedutível, quando da venda do produto localmente. 
Gerd Willi Rothmann e Luís Eduardo Schoueri aplicaram a referida norma infralegal para demonstrar, no detalhe e em números, que a Instrução Normativa n. 243/2000 acarreta um resultado prejudicial ao contribuinte, em distorção dos termos da lei. ${ }^{203,204}$

Como se pode perceber do acima exposto, a Instrução Normativa n. 243/2002 extrapolou os termos da lei, caracterizando um caso de indevida inovação jurídica por meio da regulamentação fiscal, o que não se admite em nosso ordenamento jurídico. Trata-se de mais um exemplo de falha na edição da regulamentação tributária nessa linha, dentro de muitos outros.

\section{II.F.3 Exercício do Poder Regulamentar de Forma Não Transparente - Caso do ICMS-ST de Aparelhos Celulares no Estado de São Paulo}

Como salientado anteriormente, o Supremo Tribunal Federal aceitou que a "margem de valor agregado", que compõe a base de cálculo do ICMS na substituição tributária, seja fixada pela Administração Tributária com base em dados da realidade, sob a luz do parágrafo $4^{\circ}$ do artigo $8^{\circ}$ da Lei Complementar n. 87/96.

Assim é que a Administração Tributária do Estado de São Paulo utiliza o mecanismo da substituição tributária de ICMS e fixa o percentual de margem de valor agregado nas etapas seguintes na cadeia da mercadoria sujeita ao tributo. Nessa atividade, a Administração Tributária pode fixar como base de cálculo a média ponderada dos preços a consumidor final usualmente praticados no mercado considerado, apurada por levantamento de preços, ainda que por amostragem ou por meio de dados fornecidos por entidades representativas dos respectivos setores, conforme o artigo 28-B da Lei 6.374/89, refletido no artigo 43 do Regulamento do ICMS do Estado de São Paulo.

Com a edição da Lei paulista n. 13.291/2008, o mecanismo de substituição tributária passou a ser utilizado também nas operações com produtos eletrônicos,

\footnotetext{
${ }^{203}$ ROTHMANN, Gerd Willi. Preços de Transferência - Método do Preço de Revenda menos Lucro: Base CIF (+II) ou FOB. A Margem de Lucro (20\% ou 60\%) em Processos de Embalagem e Beneficiamento. In: Revista Dialética de Direito Tributário, São Paulo, Dialética, .v. 165, p. 50 e seguintes, 2009.

${ }^{204}$ SHOUERI, Luís Eduardo. Preços de Transferência no Direito Tributário Brasileiro. 2. ed. São Paulo: Dialética, 2006. p. 152.
} 
eletroeletrônicos e eletrodomésticos, dentre os quais se incluem diferentes mercadorias como os telefones celulares, refrigeradores, cafeteiras, etc.

Com a publicação do Decreto n. 54.338/2008, os telefones celulares foram, dentre outros produtos, expressamente incluídos como mercadorias sujeitas à sistemática da substituição tributária. Com a edição da Portaria CAT n. 95, em maio de 2009, a margem de valor agregado dos telefones celulares, para fins do ICMS na substituição tributária, foi fixada em $38,58 \%$.

Ocorre que a referida margem não condiz com a realidade de grandes contribuintes estabelecidos no Estado de São Paulo que, após importarem os telefones celulares ou os adquirirem de empresas localizadas em outras unidades da federação (que não fazem a retenção do imposto), revendem tais produtos com uma margem apertada ou até mesmo com prejuízo. Esse é o caso de algumas operadoras de telecomunicações que comercializam celulares em território paulista.

Se o telefone celular poderia ser considerado como uma mercadoria de luxo catorze anos atrás, tal aparelho está ao alcance de muitos atualmente, podendo inclusive ser recebido de forma gratuita de uma empresa de telecomunicações, que utiliza tal expediente para atrair novos clientes. Há, portanto, um cenário de competitividade, em que os aparelhos celulares podem ser adquiridos isoladamente mediante pagamento de um preço ínfimo ou de forma gratuita, como item de um pacote de benefícios oferecidos por uma operadora de serviços de telecomunicações. O levantamento da margem de valor agregado na venda desse bem deve ser cuidadosamente realizado, sob a luz das peculiaridades dessa realidade.

Entretanto, a edição da Portaria CAT n. 95/2009 não veio acompanhada de uma exposição de motivos que explicasse os levantamentos realizados para fixação da margem de valor agregado dos telefones celulares em 38,58\% (e nem dos outros itens incluídos nessa portaria), considerada alta, naturalmente, pelas empresas de telecomunicações que oferecem tais produtos sem a cobrança de preço, como forma de atrair novos clientes e fidelizar os antigos. Tal portaria não distinguiu os celulares vendidos pelos fornecedores desses produtos no varejo e aqueles oferecidos sem preço por empresas de telecomunicações. 
Além disso, o percentual da margem de valor agregado dos telefones celulares de $38,58 \%$ é a mesma de outras mercadorias como freezers, impressoras, secadoras de roupas, etc., produtos muito diferentes, o que levanta profundos questionamentos acerca da legitimidade e adequação do referido percentual e do processo adotado para a sua determinação.

Também é digno de nota o fato que o Coordenador da Administração Tributária do Estado de São Paulo editou o Comunicado CAT n. 26, publicado no diário oficial de 27.06.2009, no qual foi estabelecida a data de $1^{\circ}$ de junho de 2010 como prazo de entrega de pesquisa de preços ou de margem de valor agregado, para fins de determinação da base de cálculo do ICMS-ST dos eletrônicos, eletroeletrônicos e eletrodomésticos. Tal fato indica que o percentual em questão foi fixado de forma unilateral pelo fisco estadual, sem observação cuidadosa da realidade.

Nesse contexto, empresas de telecomunicações consideraram discutir judicialmente a margem de valor agregado do ICMS-ST de telefones celulares fixada pela Administração Tributária paulista, o que acabou por desencadear, inclusive, a propositura de ação judicial, como comprova o caso do mandado de segurança n. 053.09.021377-0, em curso perante o Juízo da $12^{\text {a }}$ Vara da Fazenda Pública.

As autoridades impetradas informaram no referido processo que o percentual questionado foi calculado pela Fundação Instituto de Pesquisas Econômicas - FIPE, mas não juntaram aos autos cópia do estudo realizado pela FIPE.

Sem acesso ao estudo elaborado pela FIPE, o impetrante e outras empresas de telecomunicações, que também vendem telefones celulares, ficaram impossibilitadas de verificar se o percentual fixado na Portaria n. 95/2009 é razoável diante da realidade. A coincidência do referido percentual com o de outras mercadorias e o fato de o próprio fisco ter fixado o dia $1^{\circ}$ de junho de 2010 como prazo para entrega de informações para fixação da margem de valor agregado de ICMS-ST dos telefones celulares são dados que levantam sérias dúvidas sobre a forma como a Administração Tributária apurou o percentual de $38,58 \%$. 
Posteriormente, no dia 18.09.2009, foi publicada a Portaria CAT n. 178/2009, a qual revogou a Portaria CAT n. 95/2009. A referida portaria apenas reduziu a margem de valor agregado para $21,54 \%$ para os telefones celulares, sem esclarecer ou informar como tal margem foi determinada, não justificando a razão da substituição da margem anterior de $38,58 \%$. Ou seja, a redução do percentual de 38,58\% em quase metade e a fixação precisa da margem de valor agregado em $21,54 \%$ não foi motivada.

Até a conclusão do presente trabalho, os elementos acima citados indicam que, exatamente para um caso em que o Supremo Tribunal Federal permitiu ao fisco colher dados da realidade para fixar o percentual da margem de valor agregado do ICMS-ST (preenchendo um conceito indeterminado em lei), a Administração Tributária do Estado de São Paulo estabeleceu e alterou tal margem para os telefones celulares de forma não transparente, o que é inadmissível em um Estado de Direito e configura uma séria falha da regulamentação tributária.

Como se percebe dos exemplos acima narrados, muito embora o Supremo Tribunal Federal tenha flexibilizado a legalidade tributária e reconhecido uma maior importância da regulamentação, fato é que a Administração Tributária exerce esse poder muitas vezes de forma opressiva, sem respeitar os direitos fundamentais do contribuinte, o que exige um novo mecanismo de proteção deste último. 


\section{CAPÍTULO III - A FLEXIBILIZAÇÃO DA LEGALIDADE TRIBUTÁRIA E A SEPARAÇÃO DE PODERES}

Diante do cenário exposto nos capítulos anteriores, pode-se afirmar que o Supremo Tribunal Federal sinaliza uma tendência pela flexibilização do princípio da legalidade tributária. É necessário verificar se essa tendência implica uma automática violação ao princípio da distribuição de funções/separação de poderes, em prejuízo do contribuinte no Brasil.

Como salientado no Capítulo I, com o desenvolvimento do Estado de Direito e a maior complexidade da vida econômica, o Poder Executivo vai passando a exercer cada vez mais o poder normativo, e o Poder Legislativo vai se limitando às grandes escolhas políticas. Dessa maneira, não se pode reconhecer no Estado de Direito atual a existência pura da separação de poderes como originalmente concebida.

Pode-se afirmar que o fenômeno relacionado com o maior poder normativo do Executivo foi verificado mais cedo e de forma mais consistente nos Estados Unidos da América, tendo repercutido de forma mais intensa no Brasil apenas no final do século XX, em razão das privatizações de empresas públicas no fím da década de noventa. Isso certamente também tem relação com a prática no Brasil de o próprio Poder Executivo editar medidas provisórias, os antigos decretos-leis, bem como com a política econômica intervencionista no regime militar. ${ }^{205}$

\footnotetext{
${ }^{205}$ No Brasil, o fenômeno de concentração do poder normativo no Executivo também envolve a questão das medidas provisórias, antigos decretos-leis, podendo-se afirmar, em razão da força de lei das medidas provisórias, que o Executivo "legisla" na prática, passando o Legislativo a exercer uma atividade de supervisão do Executivo, ajustando os atos normativos desse. Sobre esse ponto, vale transcrever trecho do voto do Ministro Maurício Corrêa proferido no julgamento da Ação Direta de Inconstitucionalidade n. 1.5168 (julgada em 06.03.97; DJU 13.08.99; fls. 66/67): "Ministro Carlos Velloso, ruim com medida provisória, pior sem ela. O Estado moderno, Estado atual, sem um processo imediato, não pode tocar a administração, não pode resolver os seus problemas. Fui do Congresso Nacional; infelizmente emperra-se a máquina, não se vota, às vezes, os projetos de maior relevância. Se se questiona o decreto-lei, porque foi o decreto-lei da época dos militares, e agora se questiona a medida provisória. Tudo dá na mesma, porque depende da vontade do Congresso Nacional. Imagine, temos divergência entre onze sobre a medida provisória, o que ocorre no Congresso Nacional com quinhentos e tantos deputados e quase uma centena de senadores?" Mais adiante, o Ministro Carlos Velloso comenta (fls. 68): "No Estado liberal, dos Séculos XVIII e XIX, não se tornava necessária a existência de nenhuma técnica de delegação legislativa. Mas no Estado Social, intervencionista, Estado que os povos, a partir da Constituição de Weimar, de 1919, optaram, a delegação legislativa é necessária. Disse bem o Sr. Ministro Maurício Corrêa: ruim, com a técnica de delegação legislativa - e uma delas é a medida provisória - pior sem ela." O Supremo Tribunal Federal admite a utilização de medidas provisórias para tratar de matéria tributária, mas vem, em certos casos e em alteração de jurisprudência anterior, investigando a satisfação dos requisitos de "relevância e urgência", como
} 
Muito embora esse fenômeno tivesse e tenha maior repercussão na esfera do Direito Administrativo, ele também foi e continua sendo objeto de discussões na seara tributária, exatamente no debate dos limites entre a lei ordinária e a regulamentação tributária e dos campos de atuação do Legislativo e do Executivo. A jurisprudência do Supremo Tribunal Federal sobre a regulamentação intra legem discutida no capítulo anterior é prova disso.

Passa-se a abordar, em linhas bem gerais, como se sucedeu a evolução do poder normativo do Executivo no Direito Administrativo e no Direito Tributário nos Estados Unidos e no Brasil, tratando-se, ao final, da relação entre o princípio da distribuição de funções/separação de poderes e a recente flexibilização do princípio da legalidade tributária.

\section{III.A O Desenvolvimento do Estado Regulatório}

\section{III.A.1 Nos Estados Unidos}

O desmonte do império britânico e o surgimento dos Estados Unidos da América coincidem com a publicação do clássico Inquérito sobre a Natureza e as Causas da Riqueza das Nações de Adam Smith em 1.776, época profundamente marcada por ideais liberais.

Entretanto, nesse primeiro século de independência, não se podia afirmar que havia um puro laissez-faire nos Estados Unidos, pois já havia alguma intervenção estatal na economia, muito pequena se comparada com o papel atual desempenhado pela administração pública naquele país.

Nesse período, o direito administrativo norte-americano era pouco desenvolvido e se limitava à utilização dos writs do common law como forma de proteção dos particulares

evidencia o acórdão proferido no julgamento da Medida Cautelar em Ação Declaratória de Constitucionalidade 11-8 Distrito Federal (julgamento: 28.03.2007; DJU 29.06.2007). Sobre o tema, vale a leitura de artigo de MORAES, Alexandre de. Princípio da Eficiência e a Evolução do Controle Jurisdicional dos Atos Administrativos Discricionários. In: LEITE, George Salomão; SARLET, Ingo Wolfgang (coord.) Direitos Fundamentais e Estado Constitucional. Estudos em Homenagem a J.J. Gomes Canotilho. São Paulo: Editora Revista dos Tribunais; Coimbra (Pt): Coimbra Editora, 2009. p. 425. 
(e.g., writ of mandamus). Estudiosos da matéria naquele país ${ }^{206}$ afirmam que o mecanismo era de certa forma desajeitado, não proporcionando a efetividade e proteção almejadas, mas que, em uma análise abrangente do período, cumpriu relativamente bem o seu papel, dentro das possibilidades até então desenvolvidas e estudadas. No julgamento dos writs, as cortes se baseavam no conceito de jurisdição, distinguindo as matérias que estavam dentro da autoridade dos agentes administrativos, não sujeitas à revisão judicial, e os assuntos fora da jurisdição desses e, portanto, passíveis de controle pelo Poder Judiciário. ${ }^{207}$

Relevante e histórico foi o julgamento do caso Marbury v. Madison (1.803) pela suprema corte norte-americana. Nele, o tribunal reconheceu a supremacia da constituição, bem como a possibilidade de o poder judiciário rever os atos do poder executivo, cabendo ao primeiro dizer qual é o conteúdo da lei.

Já no período entre 1.875 até 1.930 , houve um desenvolvimento marcante da regulação norte-americana, decisivo para a configuração do direito administrativo daquele país. Naquela época, atividades como ferrovias, elevadores de grãos e outros monopólios naturais se tornaram objeto de regulação. Em 1887, foi estabelecida a primeira grande agência regulatória federal, qual seja: a Comissão de Comércio Interestadual (Interstate Commercial Commission, extinta em 1995).

Debate-se acerca das razões para criação da Comissão de Comércio Interestadual, sendo que a visão tradicional é que o fundamento para organização da referida agência era a necessidade de proteger pequenos transportadores do poder das grandes empresas ferroviárias, que tinham o monopólio da atividade. Para que a comissão a ser constituída fosse eficaz, era necessário que os reguladores da matéria fossem independentes da política e fossem técnicos na matéria ferroviária.

\footnotetext{
206 Boa parte dos comentários que seguem a respeito do desenvolvimento das agências reguladoras nos Estados Unidos foram extraídos da parte introdutória das seguintes obras: (i) BREYER, Stephen G. Richard B. Stewart; SUNSTEIN, Cass R.; VERMEULE, Adrian. Administrative Law and Regulatory Policy: Problems, Text and Cases. 6. ed. Nova Iorque: Aspen Publishers, 2006. p. 14 e seguintes; e (ii) REESE, John H. Administrative Law. Principles and Practice. St. Paul, Minn.: West Publishing Co., 1995. p. 6 e seguintes.

207 No Brasil, o estudo dos writs e do desenvolvimento do direito regulatório nos Estados Unidos foi realizado por Marçal Justen Filho (JUSTEN FILHO, Marçal. O Direito das Agências Reguladoras. São Paulo: Dialética, 2002.). Odete Medauar também aborda o tema (MEDAUAR, Odete. O Direito Administrativo em Evolução..., p. 58). Antes, Bonifacio Fortes já havia abordado o mesmo tema (FORTES, Bonifacio. Delegação Legislativa. Revista de Direito Administrativo, Rio de Janeiro, Faculdade Getúlio Vargas, v. 62, p. 353, out./dez. 1960.)
} 
Como a constituição norte-americana prevê que o congresso nacional detém o poder legislativo (artigo I, 1), debateu-se no poder judiciário daquele país acerca da constitucionalidade do exercício do poder normativo das agências, envolvendo o poder regulatório da própria Comissão de Comércio Interestadual. No julgamento do caso ICC $v$. Cincinnati, New Orleans, \& Texas Pacific Ry., 167 U.S. 479, 494 (1897), admitiu-se a possibilidade de o Congresso delegar poder normativo às agências reguladoras.

Esse tema também foi discutido na esfera estadual, tendo-se admitido o exercício do poder normativo das agências estaduais, como demonstra o caso Commission $v$. Chicago, M. \& St. P. Ry., 38 Minn. 281, 37 N.W. 782 (1888). Sobre o exercício do poder normativo da agência, afirmou o tribunal estadual:

if such a power is to be exercised at all it can only be satisfactorily done by a board or commission, constantly in session, whose time is exclusively given to the subject, and who, after investigation of the facts, can fix rates with reference to the peculiar circumstances of each road, and each particular kind of business, and who can change or modify these rates to suit the ever-varying conditions of traffic. ${ }^{208,209}$

Nessa época, foram paulatinamente estabelecidos os quatro pilares do modelo tradicional do direito administrativo norte-americano, quais sejam: (i) a legislação deve autorizar o controle dos particulares por meio de regras ou padrões que limitem a atividade administrativa; (ii) os processos utilizados pelas agências reguladoras devem assegurar que as diretivas legislativas sejam observadas; (iii) a revisão judicial deve ser garantida para assegurar que as agências atuem de forma precisa e imparcial na observação das diretivas legislativas; e (iv) os processos utilizados pelas agências devem facilitar a revisão judicial.

\footnotetext{
${ }^{208}$ Tradução livre: "se esse poder deve ser mesmo exercido, isso somente pode ser satisfatoriamente feito por um órgão ou comissão, constantemente em sessão, cujo tempo é exclusivamente dado ao assunto, e que, após a investigação dos fatos, pode fixar preços com referência às circunstâncias peculiares de cada ferrovia, e cada tipo de negócio, e pode modificar esses preços para adequar às condições sempre variantes de tráfego."

${ }^{209} \mathrm{O}$ debate acerca da violação do princípio da separação de poderes em virtude da criação de agências reguladoras com poderes normativos continou existindo por muitos anos, tendo sido desenvolvida a doutrina da não-delegação para o seu estudo (non-delegation doctrine), e também para questões de delegação direta de poderes ao presidente. Segundo essa doutrina, as decisões mais relevantes e sensíveis para o povo devem ser tomadas pelo congresso, caso no qual não podem ser conferidos poderes normativos a agências reguladoras. Um exemplo é o caso Mistretta v. United States (488 US 361), julgado pela suprema corte em 1989, no qual se aceitou os poderes normativos conferidos à agência. Por outro lado, no caso Industrial Union Department, AFL-CIO v. American Petroleum Institute (448 US 607) (conhecido como o benzene case), julgado pela suprema corte em 1980, a delegação de poderes não foi aceita.
} 
A utilização dos writs diante de atitudes abusivas dos agentes da administração foi substituída pela revisão judicial das decisões e normas das agências reguladoras, criadas por leis que estabeleciam e delimitavam os seus poderes. Afirma-se que esse modelo refletia certa desconfiança da atuação das agências reguladoras. ${ }^{210}$

Com a grande depressão nos Estados Unidos e com suas consequências econômicas e sociais, a implantação do New Deal pelo presidente Franklin Roosevelt envolveu a criação de inúmeras agências reguladoras a partir de 1932. Havia a ideia de que o capitalismo deveria ser salvo de si próprio e a administração estabeleceu um plano de recuperação nacional, como forma de restabelecer a confiança na economia. Inúmeras agências foram criadas nesse período como a Comissão de Negociação de Valores Mobiliários (Securities Exchange Commission) e o Órgão Nacional de Relações do Trabalho (National Labor Relations Board).

Havia muita crítica com relação aos poderes conferidos às agências reguladoras, considerados muitas vezes excessivos e fora do controle da lei. Por outro lado, havia aqueles que defendiam que apenas a configuração das agências com um pacote de poderes (executivo, normativo e adjudicatório) permitiria o sucesso do plano de recuperação econômica. Estes últimos argumentavam a necessidade de requisitos mínimos de controle das agências, com um processo administrativo informal e com um menor controle judicial. Um clássico defensor dessa corrente focada no processo administrativo era James M. Landis, que sustentava que a criação das agências era legítima e não constituía uma violação ao princípio da distribuição de funções/separação de poderes, nos seguintes termos:

the administrative process is, in essence, our generation's answer to the inadequacy of the judicial and legislative processes. It represents our effort to find an answer to those inadequacies by some other method than merely increasing executive power. If the doctrine of the separation of powers implies division, it also implies balance, and balance calls for equality. The creation of administrative power may be the means of preservation of that balance, so that paradoxically enough, though it may seem in theoretic violation of the doctrine of the separation of power, it may in matter of fact be the means for the preservation of that doctrine. ${ }^{211,212}$

\footnotetext{
${ }^{210}$ BREYER et al. Administrative Law..., p. 17.

211 The Administrative Process. (1938) In: STRAUSS, Peter L. Todd Rakoff; SCHOTLAND, Roy A.; FARINA, Cynthia R.. Gellhorn and Byse's Administrative Law, Cases and Comments. 9. ed, NovaIorque: The Foundation Press, Inc., 1995. p. 24.
} 
Inicialmente, as diferentes instâncias do poder judiciário norte-americano julgaram inconstitucionais as leis que haviam criado algumas agências reguladoras no New Deal. Posteriormente, diante da pressão do presidente Roosevelt para ampliar o número de juízes da suprema corte, houve uma aceitação maior das agências instituídas (com a mudança de posição de alguns membros da suprema corte), ${ }^{213}$ as quais, com a utilização do processo administrativo, tiveram as suas decisões isoladas de revisão judicial.

Muito embora a força das agências reguladoras aumentasse em virtude da jurisprudência da suprema corte, havia uma sensação, por volta de 1940, de que as agências não estavam conseguindo cumprir o seu papel, em razão de a economia não ter se recuperado. Discutiam-se muito os problemas da discricionariedade administrativa e da necessidade de se estabelecer um processo administrativo comum para todas as agências. Continuava o debate entre aqueles que defendiam um maior poder para as agências cumprirem o seu papel e aqueles que sustentavam a necessidade de controle judicial efetivo delas.

Em 1944, a suprema corte julgou o caso Skidmore v. Swift \& Co. 323 U.S. 134, no qual foi reiterado que é papel do poder judiciário estabelecer o conteúdo efetivo da lei, mas que a interpretação adotada pela Wage and Hour Division, em virtude da sua especialização e da sua experiência, deve ter o seu peso considerado. No caso, a agência havia expressado a interpretação da lei em interpretative bulletins e em informal rulings. Segundo a suprema corte, o peso efetivo a ser atribuído à interpretação adotada pela agência depende da validade do raciocínio adotado, da sua articulação, da consistência da decisão com outros casos anteriores e de outros fatores que podem servir para convencer que a interpretação da agência merece maior peso (e.g., contemporaneidade da decisão e de sua motivação).

\footnotetext{
212 Tradução livre: “o processo administrativo é, em essência, a resposta da nossa geração à inadequação dos processos judicial e legislativo. Ele representa nosso esforço para encontrar uma resposta para as inadequações por algum outro método diferente de meramente aumentando o poder executivo. Se a doutrina de separação de poderes implica divisão, ela também implica equilíbrio, e equilíbrio exige igualdade. A criação do poder administrativo pode ser o meio para preservação desse equilíbrio, de tal modo paradoxal que, apesar de poder parecer em teoria uma violação à doutrina de separação de poderes, ele pode, na realidade, ser um meio para preservação dessa doutrina."

213 O episódio é bem relatado por Paulo Fernando Silveira. (SILVEIRA, Paulo Fernando. Devido Processo Legal. Due Processo f Law. Belo Horizonte: Del Rey, 1996, p. 81-83)
} 
Nesse cenário, foi editado o Administrative Procedure Act - APA (Lei do Processo Administrativo) em 1946. Dentre os principais aspectos dessa lei, destacam-se os processos padrões que foram estabelecidos para as agências reguladoras exercerem o poder normativo, os quais exigem a publicação de minuta da regulamentação no Federal Register (registro federal), seguido da oportunidade dos interessados de apresentarem seus comentários às regras propostas e de uma decisão motivada rejeitando ou aceitando os comentários apresentados, junto com a publicação da versão final da regulamentação. É o processo de notice-and-comment, por meio do qual os poderes normativos das agências passam a ser devidamente regulados.

Nos vinte anos seguintes à promulgação do $A P A$, os tribunais aderiram ao espírito da nova lei, barrando o excesso de discricionariedade que havia sido conferido às agências anteriormente, mas sem tirar a sua mobilidade necessária. Christopher F. Edley Jr. afirma que o desenvolvimento das agências reguladoras e a edição do APA sedimentou o princípio da distribuição de funções/separação de poderes de forma peculiar nos Estados Unidos, diferente do formalismo original da teoria, mas não eliminou a preocupação com as atitudes arbitrárias da administração e a necessidade de controle judicial delas. Edley também afirma que, nesse contexto, o APA tinha e continua a ter um papel fundamental no controle da legalidade dos atos da administração. ${ }^{214}$

As preocupações que surgiram após a edição do $A P A$ foram as seguintes: necessidade de maior controle das agências pelo poder executivo, obrigação de as agências serem claras e consistentes no cumprimento de suas funções, e a longa duração e o alto custo dos processos administrativos conduzidos pelas agências. Também ocorreram casos de corrupção nas agências, os quais não foram suficientes para que o instituto fosse abandonado ou substituído.

Em 1962, a confiança nas agências e no processo administrativo começava a diminuir novamente. No entanto, exatamente nessa mesma época, uma nova série de agências, agora voltadas à efetivação de direitos individuais e difusos, foi criada, como a Agência de Proteção Ambiental (Environmental Protection Agency), a Comissão de Segurança de Produtos do Consumidor (Consumer Product Safety Commission), a

${ }^{214}$ EDLEY JR., Christopher F. Administrative Law. Rethinking Judicial Control of Bureaucracy. New Haven: Yale University Press, 1990. p. 5-7. 
Comissão de Oportunidade Igual de Emprego (Equal Employment Opportunity Commission).

A crítica às agências reguladoras nesse momento era que elas haviam sido capturadas pelos particulares que deveriam ter sido regulados, de modo que as agências não conseguiam cumprir o seu papel de proteção dos consumidores, empregados e outros beneficiários da regulação.

Nessa nova fase de desconfiança das agências, os tribunais aumentaram a legitimidade dos interessados que desejavam participar nas decisões regulatórias nos processos de edição da regulação. Os tribunais também incrementaram as formalidades processuais, com exigência de maior documentação/motivação das decisões e garantia de existência de uma efetiva oportunidade de participação dos interessados. Toda essa evolução objetivava expandir a possibilidade de uma revisão judicial adequada das decisões regulatórias. ${ }^{215}$

Já na década de 1980, a suprema corte americana decidiu casos importantes nos quais foi reconhecido que os tribunais têm limites para impor exigências processuais às agências reguladoras, ${ }^{216}$ bem como devem prestar atenção e certo respeito à interpretação da legislação realizada pelas agências, discussões essas que continuam até a atualidade.

Diante disso tudo, pode-se afirmar que o exercício de poderes normativos pelas agências reguladoras nos Estados Unidos é aceito naquele país, sendo expressamente regulado no $A P A$, não sendo essa peculiaridade do ordenamento jurídico norte-americano considerada uma violação ao princípio da distribuição de funções/separação de poderes naquele país. A grande questão atual do direito administrativo norte-americano é o

\footnotetext{
${ }^{215}$ Um caso importante e considerado uma referência, que foi julgado pela suprema corte nessa época, mas que não trata do poder normativo das agências, mas sim da prevalência ou não da interpretação dessas em um caso específico de adjudicação é o caso Citizens to Preserve Overton Park v. Volpe, 401 US 402 (1971). Nesse caso, a corte desenvolveu melhor a teoria do hard look review, segundo a qual a decisão da agência deve ser revisada de forma intensa, especialmente sob a luz da motivação adotada pela agência quando da tomada da decisão. O julgamento do poder judiciário deve ser baseado na análise ampla da íntegra dos autos do processo administrativo no qual a decisão questionada foi tomada. Essa teoria foi adotada para fins de produção normativa das agências na decisão da suprema corte, em 1983, no caso Motor Vehicle Manufacturers Association of the United States Inc. v. State Farm Mutual Automobile Insurance Co., 463 US 29, julgado um pouco antes do caso Chevron.

${ }^{216}$ Um pouco antes, em 1978, a suprema corte decidiu o caso Vermont Yankee Nuclear Power Corp. v. Natural Resources Defense Council, Inc., 435 US 519, no qual foi decidido que as cortes têm limites para impor novas medidas processuais a serem observadas pelas agências.
} 
controle judicial efetivo do exercício do poder normativo das agências ou a eventual existência de limites desse controle. ${ }^{217}$

A mensagem da suprema corte de que os tribunais devem se atentar à posição das agências reguladoras é muito importante para o presente trabalho, pois trata dos limites da interpretação da lei pelas agências na edição da regulação, motivo pelo qual aborda-se, abaixo, o caso Chevron, o principal precedente de direito administrativo norte-americano sobre o tema.

\section{III.A.1.1 O Caso Chevron}

O caso Chevron USA v. Natural Resources Defense Council (467 US 837) foi julgado pela suprema corte norte-americana em 1984. A discussão do caso era se a interpretação da agência ambiental dada ao conceito de "fonte" poluidora, utilizado em lei, deveria prevalecer judicialmente. Não se tratava de uma delegação legislativa pura, explícita, mas sim da interpretação de um conceito indeterminado utilizado em lei.

Mais especificamente, discutia-se se a agência poderia considerar as instalações poluentes de um mesmo complexo industrial como uma única fonte (caso no qual apenas uma licença para operar era necessária, o que dava maior flexibilidade às indústrias que poderiam introduzir novas fontes poluentes sem a necessidade de obter uma nova licença), ou como várias fontes poluidoras independentes (quando era preciso uma licença para cada fonte nova, sendo cada pedido examinado de forma isolada). Tratava-se, portanto, de um caso que envolvia não só juízos de legalidade, como também questões técnicas (emissões de poluente, plantas industriais, etc.).

\footnotetext{
217 "But the Court's long struggle to reconcile the growth of agencies with the Constitution yielded a solution far more complex than carte blanche for Congress to give agencies whatever power it wishes them to have. The administrative state became constitutionally tenable because the Court's vision of separation of powers evolved from the simple (but constraining) proposition that divided powers must not be commingled, to the more flexible (but far more complicated) proposition that power may be transferred so long as it will be adequately controlled." (FARINA, Cynthia. Statutory Interpretation and the Balance of Power in the Administrative State, 89 Colum. L.Rev. 452, 487-88 (1989) In: STRAUSS, Peter L; RAKOFF, Todd; SCHOTLAND, Roy A.; FARINA, Cynthia R. Gellhorn and Byse's Administrative Law, Cases and Comments. 9. ed. Nova Iorque: The Foundation Press, Inc., 1995. p. 624). Tradução livre: "Mas a longa luta da corte para reconciliar o crescimento das agências com a Constituição deu uma solução muito mais complexa que carta branca ao Congresso para dar às agências o poder que ele deseja que elas tenham. O estado administrativo se tornou constitucionalmente sustentável porque a visão da corte sobre separação de poderes evoluiu da simples (mas limitadora) proposição que poderes divididos não podem ser partilhados,
} 
A suprema corte decidiu que a agência podia determinar o preciso sentido do conceito de "fonte". Para justificar essa decisão, a corte determinou que, na verificação dos atos normativos de uma agência produzidos sob a luz da lei, deve-se primeiro verificar se a intenção do congresso está clara (ou seja, se foram utilizados conceitos determinados, i.e., com pequeno grau de indeterminação), sendo que, em caso positivo, a agência deve aplicar a lei de acordo com o sentido atribuído pelo congresso. ${ }^{218}$ No caso de o congresso não ter tratado o assunto de forma precisa (com a adoção de conceitos com maior nível de indeterminação, por exemplo), daí a agência pode implementar a sua própria interpretação, a qual deve ser respeitada pelo poder judiciário se a mesma for razoável.

Um dos questionamentos da possibilidade de a agência interpretar e atribuir o conceito preciso de "fonte poluidora" era baseado no fato de a agência já ter dado diferentes interpretações a esse conceito ao longo do tempo, de tal modo que a posição da agência não mereceria respeito. Sobre esse ponto, a corte afirmou que o processo administrativo adotado para edição da regulação, com a participação de interessados, assegurava a razoabilidade da interpretação materializada nas diferentes normas produzidas pela agência ao longo do tempo, sendo que as variações deveriam refletir circunstâncias fáticas e ambientais diferentes. Vale transcrever este trecho do julgamento:

The fact that the agency has from time to time changed its interpretation of the term source does not, as respondents argue, lead us to conclude that no deference should be accorded the agency's interpretation of the statute. An initial agency interpretation is not instantly carved in stone. On the contrary, the agency, to engage in informed rulemaking, must consider varying interpretations and the wisdom of its policy on a continuing basis. ${ }^{219}$

Peter Strauss também considera que o processo de produção normativa com a participação dos particulares foi fundamental para permitir a deferência conferida pela

para a mais flexível (porém muito mais complicada) proposição que o poder pode ser transferido desde que esse seja adequadamente controlado."

${ }^{218}$ Casos resolvidos nessa primeira etapa do teste de interpretação estabelecido em Chevron são geralmente referidos como envolvendo uma pure question of statutory construction (i.e., um questão pura de interpretação da lei) ou uma naked question of law (i.e., uma questão pura de direito).

219 Tradução livre: "O fato que a agência mudou de tempos em tempos sua interpretação do termo fonte, como os recorridos argumentam, não nos leva a concluir que nenhuma deferência deve ser dada para a interpretação da agência diante da lei. Uma interpretação inicial da agência não está escrita na pedra. Pelo contrário, a agência, para produzir normas de uma forma informada, deve considerar várias interpretações e a sabedoria da sua própria política de uma forma continuada." 
suprema corte à interpretação da agência no caso Chevron. Ou seja, foi exatamente a participação do particular que conferiu maior legitimidade à decisão tomada pela agência. Assim se manifestou Strauss:

\begin{abstract}
Chevron held that courts must accept agencies' "reasonable" interpretations of statutes if those interpretations fall within the possible range of a statute's terms. The opinion's term of reference, however, was a considered agency judgment made following established public procedures in relation to the agency's particular mandate, and not presidential instructions issued from the privacy of the White House, in the absence of public procedures, and affecting the whole field of governmental action. ${ }^{220,221}$
\end{abstract}

Os tribunais inferiores, ao seguirem o precedente Chevron, reconhecem que o aspecto processual na edição da regulação, com a participação de particulares, é fundamental para conferir maior deferência à interpretação da agência. Seguem as palavras do juiz Bauer no julgamento do caso Atchison, Topeka and Santa Fe Ry. Co. v. Pena (44 F.3d 437), decidido pelo tribunal federal do sétimo circuito em 1994:

The Supreme Court made clear in Chevron that only statutory interpretation by agencies with rule-making powers deserve substantial deference. The principal rationale underlying this deference is that in this context the agency acts as a congressional proxy; Congress develops the statutory framework and directs the agency to flesh out the operational details. But Congress typically does not permit the agency to run free in this endeavor; the Administrative Procedure Act establishes certain procedures that the agency must follow. Chief among them is the noticeand-comment provision of the APA. (...) It is this process that entitles the administrative rules to judicial deference. ${ }^{222}$

Portanto, premissa fundamental do caso Chevron para atribuir maior importância à interpretação da agência reguladora é que o processo de edição da norma reguladora tenha

\footnotetext{
${ }^{220}$ STRAUSS, Peter. Within Marbury: the Importance of Judicial Limits on the Executive's Power to Say What the Law Is. Yale Law Journal, New Haven, v. 116, p. 60, 2006.

221 Tradução livre: "Chevron decidiu que as cortes devem aceitar as interpretações razoáveis das agências diante da lei se tais interpretações se encaixam dentro das possibilidades dos termos constantes das leis. O termo de referência da decisão, contudo, foi um julgamento considerado de uma agência seguido de processos públicos com relação ao mandato particular da agência, e não instruções presidenciais editadas da privacidade da Casa Branca, na ausência de processos públicos, e afetando todo um campo de ação governamental."

${ }^{222}$ Tradução livre: "A Suprema Corte deixou claro em Chevron que somente interpretações da lei pelas agências com poderes normativos merecem deferência substancial. O principal raciocínio subjacente para essa deferência é que nesse contexto a agência age como um procurador do congresso; o Congresso desenvolve o arcabouço legal e dirige a agência a refletir os detalhes operacionais. Mas o Congresso tipicamente não permite que a agência corra livre nessa empreitada; a Lei de Processos Administrativos
} 
contado com a participação de particulares e tenha observado o APA. Sem o respeito desses requisitos, a interpretação da agência terá um peso muito menor.

O caso Chevron era e continua sendo um dos julgamentos mais importantes da suprema corte norte-americana, sendo constantemente citado e estudado nos Estados Unidos. Até no direito tributário brasileiro, esse caso produz ecos. ${ }^{223}$

A harmonização desse caso com o princípio da distribuição de funções/separação de poderes é importante, mas somente é possível com a aceitação do controle do poder normativo das agências pelo poder judiciário, sob pena de se concentrar muito poder no executivo e de se violar o precedente Marbury vs. Madison (1803), comentado acima. ${ }^{224,225}$

Dessa maneira, os tribunais norte-americanos podem acolher a interpretação da agência apenas quando: (i) foram utilizados conceitos indeterminados em lei; (ii) foram respeitados os processos cabíveis para a edição de norma infralegal por agência, com a participação de particulares; e (iii) a interpretação final da agência for razoável (com respeito, evidentemente, aos direitos fundamentais). Na hipótese de esses requisitos não serem observados, a interpretação constante da regulação não merecerá qualquer deferência, quando haverá uma violação ao princípio da distribuição de funções/separação de poderes.

Registre-se que continua a haver muita discussão acerca dos limites dos poderes normativos das agências diante da lei sob a luz do caso Chevron, tendo a suprema corte aplicado esse precedente a outros casos posteriores. ${ }^{226} \mathrm{O}$ atentado de onze de setembro de 2001 e a crise econômica mundial deflagrada em 2008 são eventos que provavelmente

estabelece certos processos que a agência deve seguir. O líder entre eles é o dispositivo de notificação e comentários do $A P A($...). É esse processo que dá às regras administrativas direito à deferência judicial.”

${ }^{223}$ TORRES, Ricardo Lobo. Tratado de Direito Constitucional... p. 436 (nota 141).

${ }^{224} \mathrm{Na}$ doutrina norte-americana, Cass R. Sunstein defende que o caso Chevron seria, de certa forma, uma decisão anti-Marbury, eis que proibiria os juízes de fazerem política, os quais seriam os políticos com maior mandato. Assim, Chevron asseguraria uma zona saudável de decisão administrativa fora do alcance do poder judiciário. (CASS, R. Sunstein. Beyond Marbury: The Executive's Power to Say What the Law is. Yale Law Journal, New Haven, v. 115, p. 2580, 2006.). Na edição seguinte do mesmo Yale Law Journal, Peter Strauss questiona essa visão e ressalta a permanente necessidade de imposição de limites no poder do executivo de dizer qual é o conteúdo da lei. Strauss defende que há um irreductible minimum of the judicial task, que não poder ser renunciado (STRAUSS, Peter. Within Marbury..., p. 65).

${ }^{225}$ BREYER et al. Administrative Law..., p. 247.

${ }^{226}$ REESE, John H. Administrative Law. p. 770 e seguintes. 
trarão à suprema corte norte-americana novos casos em que se discutirão os limites da interpretação adotada pelas agências e dos poderes conferidos a elas.

\section{III.A.2 No Brasil}

Após a independência do Brasil em 1822, esperava-se a promulgação da primeira Constituição brasileira de forma célere, mas D. Pedro I dissolveu a Assembleia Nacional Constituinte em 1823, em razão de o texto em discussão limitar o poder do imperador.

No ano seguinte, foi editada a primeira Constituição brasileira, que estabelecia o princípio da distribuição de funções/separação de poderes e incluía, além dos poderes legislativo, executivo e judiciário, o poder moderador. Com o fim do império e com a proclamação da república, foi editada a Constituição de 1891, a qual, inspirada na constituição norte-americana, adotou o princípio da distribuição de funções/separação de poderes, não tendo sido mantido o poder moderador.

Ruy Cirne Lima informa que os regulamentos eram muito importantes durante o Império e sob a Constituição de 1891, quando ocorriam diversas delegações legislativas, geralmente aceitas pelo Poder Judiciário na República, salvo quando inconstitucionais, ${ }^{227}$ como no caso das delegações legislativas realizadas nos orçamentos. ${ }^{228}$

O fim da república velha diante da revolução de 1930, bem como a revolução constitucionalista de 1932 desencadearam um movimento que culminou com a edição da Constituição brasileira de 1934, a qual também manteve o princípio da distribuição de funções/separação de poderes.

Apesar de não tratar diretamente sobre a atribuição de poderes normativos a agências reguladoras, não se pode deixar de mencionar a celeuma jurídica acerca da atribuição de poder normativo aos tribunais trabalhistas, surgida em 1935. Naquele ano, foi enviado à Câmara dos Deputados o projeto de organização da Justiça do Trabalho. Membro da Comissão de Constituição e Justiça daquela casa legislativa, Waldemar

${ }^{227}$ LIMA, Ruy Cirne. Princípios de Direito Administrativo. 6. ed. São Paulo: Ed. Revista dos Tribunais, 1987. p. 40.

${ }^{228}$ FORTES, Bonifacio. Delegação legislativa. p. 366. 
Ferreira $^{229}$ criticou severamente o projeto apresentado e publicou um parecer sobre o tema. Sendo um dos autores do projeto e diante da crítica do respeitável Waldemar Ferreira, Oliveira Vianna se julgou no dever de vir a público defendê-lo, tendo publicado uma série de artigos sobre o tema, inclusive sobre a questão da atribuição de poder normativo aos tribunais trabalhistas e o princípio da distribuição de funções/separação de poderes. ${ }^{230}$

Naquela época, Oliveira Vianna já afirmava que o princípio da distribuição de funções/separação de poderes: "há de ser interpretado sem rigores absolutos, sem ortodoxismos exagerados, com o sentido relativo com que tem sido e está sendo interpretado e aplicado nos países da mais alta cultura constitucional e política." ${ }^{231}$ Mais adiante, afirmava Vianna, sob a luz da comparação feita com a aplicação do princípio da distribuição de funções/separação de poderes na Alemanha, na Inglaterra e nos Estados Unidos:

o que a experiência dos povos mais velhos tem verificado é que este princípio, mesmo quando é consagrado explícita e taxativamente nos textos constitucionais, não pode ter uma aplicação muito rigorosa, sob pena de tornar impossível a administração da coisa pública. ${ }^{232}$

Para demonstrar a compatibilidade da conferência de poderes normativos aos tribunais do trabalho e o princípio da distribuição de funções/separação de poderes, Oliveira Vianna se debruçou exatamente sobre a evolução das agências reguladoras e a jurisprudência da suprema corte nos Estados Unidos da América da época, comentada em linhas gerais no item anterior do presente trabalho. Vianna também apontou as autarquias que já eram dotadas de poderes normativos no Brasil, quais sejam: o Departamento Nacional do Café (o "DNC"), o Instituto de Café de São Paulo, o Instituto de Açúcar e as Delegacias do Trabalho Marítimo. ${ }^{233}$

Ainda nesse período, o Supremo Tribunal Federal teve oportunidade de se manifestar sobre o poder do DNC de fixar o preço do café. No julgamento do mandado de

\footnotetext{
${ }^{229}$ Vide: FERREIRA, Waldemar. A Justiça do Trabalho. Pareceres proferidos na Comissão de Constituição e Justiça da Câmara dos Deputados. Rio de Janeiro: Câmara dos Deputados, 1937; e (ii) Princípios da Legislação Social e Direito Judiciário do Trabalho. Volume II. Rio de Janeiro: Editora Freitas Bastos, 1939. p. 144.

${ }^{230}$ VIANNA, Oliveira. Problemas de Direito Corporativo. Introdução de Alberto Venâncio Filho. 2. ed. Brasília: Câmara dos Deputados, Coordenação de publicações, 1983. p. 11 e seguintes.

${ }^{231}$ VIANNA, op. cit., p. 44.

${ }^{232}$ Ibid., p. 46.
} 
segurança n. 333 (DF), o Supremo proferiu acórdão, datado de 9 de dezembro de 1936, no sentido da inconstitucionalidade do tipo de intervenção realizada pelo DNC, que seria confiscatória em virtude de obrigar a alienação compulsória do café. Posteriormente, em 16 de abril de 1937, no julgamento do mandado de segurança n. 356 (DF), a nossa Corte Suprema estabeleceu que a faculdade do DNC de fixar o preço do café constituía uma competência regulamentar dessa autarquia, ainda que implicasse um sacrifício para o particular em um contexto de economia dirigida. ${ }^{234}$

Em 1937, Getúlio Vargas articulou o Golpe do Estado Novo e, no mesmo ano, editou a chamada Constituição polaca, inspirada na Constituição da Polônia, fascista. Essa Constituição eliminou a tradicional distribuição de funções/separação de poderes, tendo em vista que o presidente da república (o ditador) era a autoridade suprema do Estado e tinha os poderes de coordenar a atividade dos órgãos representativos e de editar os decretos-lei.

Nessa época, o chamado Conselho de Economia Nacional, previsto na Constituição nos artigos 57 e seguintes, tinha poderes normativos. Também nesse período, diversas conquistas sociais foram alcançadas, incluindo a organização da justiça do trabalho, instituída por meio do Decreto-lei n. 1237/39, com poder normativo dos tribunais do trabalho para tratar de dissídios coletivos. ${ }^{235}$

Após a deposição de Vargas em outubro de 1945 e a promulgação da Constituição Federal de 1946, voltou a viger e produzir efeitos no país o princípio da distribuição de funções/separação de poderes. O instituto do decreto-lei não foi mantido, tendo sido atribuída ao poder executivo apenas a iniciativa de leis reguladoras no âmbito interno da Administração Pública, bem como a competência regulamentar.

\footnotetext{
${ }^{233}$ Ibid., p. 59-60 e 63 e seguintes.

${ }^{234}$ RODRIGUES, Lêda Boechat. História do Supremo Tribunal Federal. Tomo IV - Volume I / 1930-1963. Rio de Janeiro: Civilização Brasileira, 2002. p. 48-50.

${ }^{235} \mathrm{O}$ poder normativo da Justiça do Trabalho continua a existir até os dias atuais, sendo atualmente regulado no parágrafo $2^{\circ}$ do artigo 114 da Constituição Federal de 1988, com a redação dada pela Emenda Constitucional 45/2004. Em virtude dessa emenda constitucional, o poder normativo da Justiça do Trabalho foi reduzido, o que não desqualifica a experiência normativa dessa corte para fins de estudo do princípio da distribuição de funções/separação de poderes. Antes da referida alteração constitucional, o Supremo Tribunal Federal reconheceu a legitimidade do poder normativo da Justiça do Trabalho (e.g., Recurso Extraordinário n. 114.836; julgamento: 01.12.1997; DJU 06.03.98 - Recurso Extraordinário n. 197.911; julgamento: 24.09.96; DJU: 07.11.97)
} 
Em 1949, o Tribunal Federal de Recursos reconheceu que o Ministério da Aeronáutica poderia fixar, independente de lei, preços e tarifas, em virtude da especialidade dessa atividade. ${ }^{236}$ Essa decisão veio na esteira de um julgamento do Supremo Tribunal Federal do ano anterior que havia admitido a atribuição de poder normativo à Comissão Central de Preços (acórdão no Habeas Corpus n. 30.355). ${ }^{237}$

Também nesse período, com a instituição do Plano SALTE, poderes normativos foram delegados ao Poder Executivo, tendo a Comissão de Constituição e Justiça da Câmara dos Deputados considerado constitucional referida atribuição de poderes. ${ }^{238,239}$ No caso, defendeu-se que não haveria uma delegação de poderes, mas sim uma habilitação do Poder Executivo para que este pudesse cumprir a missão que lhe foi outorgada de crescimento do país.

Em 1952, a Lei n. 1779 criou o Instituto Brasileiro do Café, autarquia federal, e o habilitou a exercer poderes normativos para realizar a política econômica do café brasileiro no país e no estrangeiro, o qual substituiu o DNC. Outros institutos setoriais com poderes normativos foram criados na mesma época.

No final de 1964, foi criado o Banco Central do Brasil como uma autarquia por meio da Lei n. 4595. Desde a sua criação, o Banco Central foi munido de poderes

\footnotetext{
${ }^{236}$ Bonifacio Fortes comenta o caso (FORTES, Bonifacio. Delegação legislativa, p. 371): “O Tribunal Federal de Recursos, em 1949 (Mandado de Segurança n. 437, de 12-IX-1949), quando o Sindicato Nacional das Empresas Aeroviárias interpôs o "writ" contra o Ministério da Aeronáutica argumentando contra a validade do Dec-Lei n. 97922, de 6-IX-1946, que autorizava o Ministério a fixar preços e tarifas, seguia a jurisprudência do Supremo já esposada em 1948 por ocasião da arguição de inconstitucionalidade do Dec-Lei n. 9125, de 4-IV-1946, que criou a Comissão Central de Preços, destinada a controlar preços e utilidades. (...) o TFR negou a segurança, dispondo que "Pode o Executivo fixar preços e tarifas, pois não são tributos que exigem lei especial" e que "desaparece a vedação da delegação de poderes quando o órgão executivo da lei para aplicar a mesma lei, deve apurar fatos de ordem técnica."

237 "Delegação legislativa - tabelamento de preços - lei e regulamento - A proibição da delegação de poderes não é absoluta; deve ceder quando houver necessidade de assegurar a execução de outro preceito constitucional." (acórdão publicado na Revista de Direito Administrativo, vol. 21, p. 134).

${ }^{238}$ FORTES, op. cit., p. 373.

239 "Preconizando a interpretação restritiva do artigo 36, parágrafo $2^{\circ}$ da Constituição da época, o eminente parlamentar advogava a legitimidade de projeto de lei que autorizava o Presidente da República a tomar todas as providências e expedir os atos necessários à execução do Plano Salte (a qual se imputava a eiva de proibida delegação de poderes), asseverando: Aliás, aproveito a oportunidade para recordar à Câmara que o que se vai fazer dentro do Plano Salte não é uma delegação de poderes. Esta é uma expressão viciosa, visto que a Constituição veda as delegações de poderes. Não podemos dizer que estamos fazendo o que a Constituição proibe. O que se vai dar é uma habilitação de autoridade - foi o nome que a Suprema Corte Americana atribuiu a essa medida. (...)" (TÁCITO, Caio. Comissão de Valores Mobiliários. Poder Regulamentar. In: Temas de Direito Público (Estudos e Pareceres). $2^{\circ}$ Vol. Rio de Janeiro: Renovar, 1997. p. 1078).
} 
normativos para habilitá-lo a regular os mercados de crédito e de câmbio, dentre outras matérias. Até hoje, o papel normativo dessa autarquia é marcante. ${ }^{240}$

A Constituição de 1967, editada durante o regime militar, manteve, na teoria, o princípio da distribuição de funções/separação de poderes. O instituto do decreto-lei foi reinstituído nessa oportunidade.

Em 1976, foi criada a Comissão de Valores Mobiliários por meio da Lei n. 6385, tendo essa autarquia sido dotada com poder normativo para regular o mercado de valores mobiliários e as matérias expressamente previstas na Lei n. 6404/76. Do mesmo modo que o Banco Central, a CVM desempenha importante papel regulatório até os dias atuais. ${ }^{241}$

A Constituição Federal de 1988 manteve o princípio da distribuição de funções/separação de poderes e substituiu o instituto do decreto-lei pela medida provisória.

$\mathrm{Na}$ segunda metade da década de noventa, quando das privatizações de grandes empresas públicas nacionais, inaugurou-se uma nova fase no direito administrativo pátrio, quando foram instituídas novas agências reguladoras com poderes normativos, em um modelo mais próximo das norte-americanas. Dentre elas, cabe citar a Agência Nacional de Telecomunicações (Lei n. 9472/97), a Agência Nacional de Energia Elétrica (Lei n. 9427/96) e a Agência Nacional do Petróleo, Gás Natural e Biocombustíveis (Lei n. 9478/97). Depois delas, muitas outras agências foram criadas.

\footnotetext{
240 “Às formas veladas de delegação legislativa conecta-se diretamente a importância assumida pelas fontes infralegais do Direito Administrativo. Nenhum de nós ignora o significado e o poder dos regulamentos, resoluções, circulares, portarias etc., pelas quais de um só golpe, como ocorre com as Resoluções do Conselho Monetário Nacional ou com as circulares do Banco Central, altera-se o desenho de importantíssimos setores da Nação. O problema, aliás, não é só nosso e encontra símile na maioria dos países democráticos do nosso tempo.". (SILVA, Almiro do Couto. Princípios da Legalidade da Administração Pública e da Segurança Jurídica no Estado de Direito Contemporâneo. Revista de Direito Público, São Paulo, Editora Revista dos Tribunais, v. 84, p. 52, 1987.)

${ }^{241}$ Em 1986, Caio Tácito proferiu parecer sustentando a constitucionalidade do poder normativo da CVM, nos seguintes termos: "A sensibilidade do mercado financeiro recomendava, porém, que se concretizassem, ainda mais, as hipóteses de conduta ilícita. (...) Coerente, no entanto, com o propósito de orientar o mercado e de prevenir abusos ou equívocos, preferiu o colegiado do órgão instruir - e, portanto, educar - os agentes do mercado financeiro quanto aos conceitos a adotar no julgamento individual da conduta de cada qual, em face das diversas figuras legalmente interditadas. Não há nessa explicação prévia de critérios, com que se visa proteger a boa fé dos administradores probos e idôneos, prevenindo-os contra as incertezas da exegese, qualquer excesso ou extrapolação de norma legal proibitiva." (TÁCITO, Caio. Comissão de Valores Mobiliários, p. 1092-1093).
} 
Em 1999, foi editada a Lei n. 9.784/99, que tratou do processo administrativo no âmbito da Administração Pública federal, direta e indireta, lei essa que, apesar de constituir um relevante avanço, não estabeleceu regras mínimas comuns para o exercício dos poderes normativos pelas entidades da Administração Pública direta e indireta.

Demonstra-se a partir desse breve histórico que, também no Brasil, a Administração Pública direta e indireta e os próprios tribunais do trabalho foram dotados de certos poderes normativos há muito tempo, ${ }^{242}$ o que não constitui uma violação per se do princípio da distribuição de funções/separação de poderes. O tema foi inclusive objeto de debate no Poder Judiciário, havendo julgados que aceitaram a possibilidade de exercício de poder normativo pelo Executivo, desde que a Administração Pública tivesse sido devidamente habilitada pela lei para tanto.

Apesar disso, ainda há na doutrina atual respeitáveis vozes sustentando a inconstitucionalidade do modelo das agências com a outorga de poderes normativos a essas. $^{243}$ A base, para esse questionamento, é de que toda a atividade da Administração Pública (com exceção da regulação de assuntos internos) deve ser realizada conforme a lei, e não em decorrência de uma habilitação legal, refletindo uma visão estanque do princípio da distribuição de funções/separação de poderes.

Bem por isso, é totalmente pertinente o comentário de Gilberto Bercovici de que a defesa do princípio da distribuição de funções/separação de poderes de forma radical e cega, com a posição de que a atribuição e o exercício de poderes normativos por entes da Administração Pública seriam inconstitucionais per se, está totalmente dissociada da realidade, ignorando os problemas efetivos envolvendo esse assunto, especialmente com relação ao seu controle judicial (e.g., como o poder normativo é exercido, seus limites, etc.). ${ }^{244245}$

\footnotetext{
${ }^{242}$ Marçal Justen Filho também reconhece a pré-existência das agências reguladoras, antes da segunda metade da década de noventa, quando foram criadas as recentes agências reguladoras. (FILHO, Marçal Justen. O Direito das Agências Reguladoras. p. 329.)

${ }^{243}$ Celso Antônio Bandeira de Mello entende que as agências teriam poderes apenas para expedir normas apenas dentro da chamada "supremacia especial", de tal modo que tais entes da Administração Pública indireta não poderiam impor restrições à liberdade e à propriedade sem que houvesse uma lei anterior prevendo tais limitações. (MELLO, Celso A.B. de. Curso de Direito Administrativo..., p. 159, 724-725).

${ }^{244}$ BERCOVICI, Gilberto. Separação de Poderes. Revista de Informação Legislativa, Brasília, Senado Federal, Subsecretaria de Edições Técnicas, v. 150, p. 225, abr/jun 2001.

${ }^{245}$ Paulo Otero afirma que, também em Portugal, os centros normativos proliferam: "Há hoje uma proliferação de centros do poder e de produção de normas" que, impregnando o sistema jurídico de uma
} 
Eros Grau, por exemplo, compreende essa problemática e afirma que

a desmistificação da legalidade supõe a compreensão de que não há necessária vinculação dela à chamada 'separação' de poderes. Vale dizer: a legalidade será observada ainda quando a função normativa seja desenvolvida não apenas pelo Poder Legislativo. ${ }^{246}$

O que importa é a possibilidade adequada e efetiva de revisão judicial dos atos normativos expedidos pela Administração Pública.

Tendo sido exposto breve histórico acerca da atribuição e desenvolvimento do poder normativo da Administração Pública no Direito Administrativo e a compatibilidade desse fenômeno com o princípio da distribuição de funções/separação de poderes, cabe agora discutir o impacto disso no campo tributário.

\section{III.B O Direito Tributário no Estado Regulatório}

\section{III.B.1 Nos Estados Unidos}

Ao contrário da nossa atual carta constitucional, não há na constituição federal norte-americana um título/capítulo exclusivamente dedicado ao sistema tributário daquele país, mas os princípios da legalidade tributária, da uniformidade da tributação e alguns outros estão presentes.

Certo é que, desde Marbury v. Madison (1803), há a preocupação de o poder judiciário norte-americano proteger o contribuinte contra a cobrança abusiva de tributos. O juiz Marshall assim se manifestou para demonstrar a necessidade de haver a possibilidade de controle constitucional de questões tributárias pelo poder judiciário:

it is declared that "no tax or duty shall be laid on articles exported from any state." Suppose a duty on the export of cotton, of tobacco, or of flour; and a suit instituted to recover it. Ought judgment to be rendered in this

considerável complexidade, gera um concurso de fontes. Longe vai o tempo em que a decisão normativa se encontrava concentrada num único órgão: o princípio da separação de poderes, primeiro, a assunção de poderes legislativos pelo executivo, depois, e os princípios de descentralização normativa e da subsidiariedade, por último, produziram uma verdadeira pulverização do exercício da competência normativa." (OTERO, Paulo. Legalidade e Administração Pública..., p. 441).

${ }^{246}$ GRAU, Eros. O Direito Posto... p. 179. 
case? Ought the judges to close their eyes on the constitution, and only see the law? $?^{247}$

Considerando que o fisco federal norte-americano também caracteriza uma agência para fins do $A P A$, verifica-se que as regras processuais para produção de normas previstas nessa lei são aplicáveis não somente às agências regulatórias em geral, como também ao fisco e a toda autoridade que se enquadrar no conceito de agência estabelecido nessa lei de processo administrativo. ${ }^{248}$ Desse modo, o fisco também deve observar as regras gerais de rule making do APA na produção da regulamentação fiscal.

A esse respeito, é importante notar que, fora os casos em que a lei determina explicitamente a participação do contribuinte na edição da regulamentação fiscal, o próprio $A P A$ registra que tal participação não é obrigatória na edição de regras meramente interpretativas, declarações gerais da política da agência, bem como regras de organização, procedimento ou prática interna das agências. A participação também não é obrigatória quando a agência conclui que o processo de edição da regulamentação com a participação do interessado é impraticável, ${ }^{249}$ desnecessário ou contrário ao interesse público. ${ }^{250}$

Nesse passo, a participação do contribuinte é obrigatória nos casos em que são editados regulamentos fiscais delegados, de caráter legislativo e com poder vinculativo (editados sob specific authority), quando a atividade de regulamentação pode inovar a ordem jurídica naquele país. Por outro lado, a participação do contribuinte é facultativa nas situações em que são elaborados regulamentos fiscais de mero caráter interpretativo e

\footnotetext{
${ }^{247}$ Tradução livre: "Está declarado que "nenhum tributo ou tarifa deve ser exigido sobre artigos exportados de um estado." Suponha uma tarifa na exportação de algodão, tabaco, ou de farinha; e um processo para recuperá-la. Deve julgamento ser realizado nesse caso? Devem os juízes fechar os olhos diante da constituição, e apenas ver a lei?". O artigo $1^{\circ}$, seção 9 da constituição norte-americana estabelece que não nenhum tributo ou tarifa deve ser exigido sobre artigos exportados de um estado.

248 A seção 551 do APA define uma agência como cada autoridade do governo dos Estados Unidos, independente de estar ou não sujeita a revisão por outra agência, com algumas exceções expressamente listadas como o Congresso, os tribunais judiciais, os governos dos territórios ou possessões dos Estados Unidos, etc.

${ }^{249}$ Apenas como uma referência, a proposta inicial de regulamentação da plantação e certificação de produtos orgânicos do Departamento de Agricultura nos Estados Unidos recebeu aproximadamente 200.000 comentários. Ou seja, o processo de edição de regulamentação com a participação do interessado pode ser realizado em larga escala. Vide: STRAUSS, Peter L; RAKOFF, Todd; FARINA, Cynthia R. 1999 Supplement to Gellhorn and Byse's Administrative Law, Cases and Comments. 9. ed, Nova Iorque: The Foundation Press, Inc., 1999. p. 42-44.

${ }^{250}$ Outra regra relevante e que chama a atenção é a que confere o direito de petição ao interessado para requerer a edição, alteração ou revogação de um regulamento.
} 
sem poder vinculativo (editados sob general authority). ${ }^{251,252}$ Mesmo neste último caso, o fisco norte-americano opta por normalmente permitir a participação do contribuinte no processo de edição dos regulamentos. ${ }^{253,254,255}$

A regulamentação tributária também é editada em alto número nos Estados Unidos da América. Como no Brasil, o contribuinte norte-americano também questiona judicialmente a regulamentação tributária editada pelo poder executivo, sendo importante, no presente trabalho, entender os limites da revisão judicial naquela jurisdição.

Sendo o fisco norte-americano uma agência como as demais regulatórias, Chevron seria então o precedente judicial aplicável à interpretação dos regulamentos físcais editados sob general ou specific authority, já que Chevron, como explicado anteriormente, estabeleceu que, quando a lei utiliza conceitos indeterminados, a interpretação da agência deve prevalecer desde que seja razoável, o que não violaria o princípio da distribuição de funções/separação de poderes.

\footnotetext{
${ }^{251} \mathrm{O}$ artigo 7805 do Internal Revenue Code estabelece que o Secretário do Tesouro tem o poder de editar todas as regras e regulamentos necessários para aplicação da legislação tributária. As normas infralegais editadas com base nesse poder são aquelas produzidas sob general authority.

${ }^{252}$ WATSON, Camilla E.; BILlmAN, Jr. Brookes D. Federal Tax Practice and Procedure. Saint Paul: West, 2005. p. 12.

${ }^{253}$ Isso é comprovado pela constatação feita na seguinte decisão do Poder Judiciário norte-americano: Bankers Life and Casualty Co. v. United States. United States Court of Appeals, Seventh Circuit, 1998. 142 F.3d 973. "The tax code contains a myriad of specific congressional instructions regarding rulemaking. Pursuant to the Administrative Procedures Act ("APA"), the IRS issues these rules with full notice and comment. See 5 U.S.C. 553 (1994). In the middle, between letter rulings and specific authority regulations, are general authority regulations under its power to "prescribe all needful rules and regulations." See I.R.C. 7805(a) 1994. While the IRS takes the position that regulations issued solely under this general authority do not require notice and comment, the agency nevertheless usually follows full notice and comment procedures." Tradução livre: "O código tributário contém inúmeras instruções específicas do congresso com relação à produção da regulamentação. De acordo com a lei de processo administrativo, o IRS edita essas regras com ampla notificação e comentário. Veja 5 USC 553 (1994). No meio, entre as respostas a consultas e regulamentos editados sob autoridade específica [do congresso], estão os regulamentos editados sob autorização geral sob o poder de "prescrever todas as regras e regulamentos necessários. Veja IRC 7805(a) 1994. Enquanto o IRS adota a posição de que a regulamentação editada sob autorização geral não exige notificação e comentário, a agência não obstante usualmente segue os processos de notificaçao e comentário."

${ }^{254}$ Nesse sentido, COVERDALE, John F. Court Review of Tax Regulations and Revenue Rulings in the Chevron Era. The George Washington Law Review, Washington DC, v. 35, p. 64, novembro de 1995.

${ }^{255}$ Chama atenção a prática do fisco norte-americano de permitir a participação do contribuinte na edição de regulamentos sob general authority, apesar de não haver uma obrigação legal nesse sentido. A razão de tal prática é produzir uma regulamentação de melhor qualidade, bem como de tentar atribuir ao regulamento editado uma maior legitimidade, dando-lhe mais força em uma eventual discussão judicial, com a demonstração de que foram respeitados os direitos fundamentais do contribuinte. Entretanto, essa força é limitada e não impede, de forma alguma, a plena revisão judicial.
} 
Todavia, no caso United States v. Mead Corporation, 533 US 218 (2001), a suprema corte norte-americana decidiu que a classificação aduaneira adotada pelo fisco daquele país para um determinado bem importado não deveria ser observada sob Chevron, mas merecia algum peso sob Skidmore v. Swift \& Co., 323 U.S. 134 (1944), acima comentado. A classificação aduaneira em questão havia sido estabelecida em um ato normativo não precedido do processo administrativo com a participação do contribuinte (era uma ruling letter) e envolvia juízos de legalidade e técnicos. Não era um caso de delegação legislativa.

Liderando a corte sobre o tema, para justificar a aplicação de Skidmore, e não de Chevron, o justice Souter afirmou:

The Court, on the other hand, said nothing in Chevron to eliminate Skidmore's recognition of various justifications for deference depending on statutory circumstances and agency action; Chevron was simply a case recognizing that even without express authority to fill a specific statutory gap, circumstances pointing to implicit congressional delegation present a particularly insistent call for deference. ${ }^{256}$

Em razão desse julgamento, pode-se afirmar que, mesmo quando a lei tributária norte-americana utiliza conceitos indeterminados, o precedente Chevron não seria aplicável à regulamentação fiscal editada sob general authority naquele país, mas sim o precedente Skidmore. Assim, apenas e tão somente a regulamentação editada sob specific authority (caso de delegação) mereceria uma maior deferência, pois o seu processo de edição contaria com a participação obrigatória do contribuinte, o que manteria o equilíbrio das funções/poderes. ${ }^{257}$ Chevron poderia a princípio ser aplicado apenas nesse caso.

\footnotetext{
${ }^{256}$ Tradução livre: “A Corte, por outro lado, não disse nada em Chevron para eliminar o reconhecimento de Skidmore de várias justificativas para deferência dependendo das circunstâncias legais e da ação da agência; Chevron foi simplesmente um caso que mesmo sem autorização expressa para preencher uma lacuna legal específica, circunstâncias apontando para implícita delegação do congresso apresentaram um pedido particular insistente por deferência."

257 Tendo em vista que o fisco norte-americano é uma agência e que Chevron é aplicável no direito administrativo quando são utilizados conceitos indeterminados, alguns estudiosos naquele país são contrários ao tratamento específico dado em Mead para regulamentação tributária editada sob general authoritiy, defendendo que essa exceção para a matéria tributária não deveria existir e que Chevron deveria ser aplicável à regulamentação fiscal em geral, independente de ter sido editada sob general ou specific authority. Vide HICKMAN, Kristin E. The Need for Mead: Rejecting Tax Exceptionalism in Judicial Deference. Minnesota Law Review, Minneapolis, Universidade de Minnesota, v. 90, p. 1537, 2006. Antes de Mead, já se estudava o impacto de Chevron na interpretação da regulamentação tributária naquele país, sendo que alguns defendiam que Chevron tinha causado um impacto relativo; na realidade, chegam a defender que Chevron pode ter diminuido o nível de deferência conferido à regulamentação fiscal, na medida em que se passou a exigir uma maior motivação e processo do fisco. Vide APRILL, Ellen. Muffled Chevron: Judicial Review of Tax Regulations. Florida Tax Review, Gainesville, Universidade da Flórida, v. 3, p. 51, 1996.
} 
Por esse motivo, quando se observa a aplicação do caso Chevron a discussões tributárias nos Estados Unidos, deve-se ter em mente que a suprema corte se manifestou especificamente sobre o tema no caso Mead em 2001, e que casos anteriores desconsideram, naturalmente, esse importante precedente. ${ }^{258}$ Não há ainda um consenso sobre a forma correta de aplicação de Skidmore, Chevron e Mead na jurisprudência mais recente de tribunais inferiores e na doutrina. ${ }^{259260}$

Verifica-se, portanto, que a atribuição de poder normativo ao fisco norte-americano para edição de regulamentação sob general authority também não é considerada uma violação ao princípio da distribuição de funções/separação de poderes naquele país, sendo que, nos casos em que a regulamentação é editada sob uma delegação legislativa (specific authority), é obrigatória a participação do contribuinte na sua edição, quando a interpretação do fisco merece maior respeito. Mesmo nos casos em que essa participação não é obrigatória, o fisco federal norte-americano permite a participação do contribuinte na produção da regulamentação fiscal.

\section{III.B.2 No Brasil}

No Brasil, a Constituição Federal é clara ao fixar uma série de princípios distinta para o Direito Administrativo (artigo 37) e para o Direito Tributário (artigo 145 e seguintes). Não há dúvida alguma de que os padrões de legalidade fixados no artigo 37 e no artigo 150, I da carta política são diferentes. A jurisprudência do Supremo Tribunal Federal construída acerca do princípio da legalidade tributária e sobre a atribuição de poderes normativos a entes da Administração Pública, comentada no Capítulo I e acima respectivamente, constituem evidências inquestionáveis dessa distinção.

\footnotetext{
258 Assim, deve-se ler a afirmação de Ricardo Lobo Torres de que a Suprema Corte vem deferindo ao regulamento de imposto de renda a competência para interpretar as ambiguidades da lei tributária, com referência à Chevron, como sendo apenas e tão somente aplicável aos casos antes do julgamento de Mead ou a casos envolvendo delegações legislativas expressas (regulamentos editados sob specific authority). Logo, tais casos, se fossem novamente julgados depois de Mead, poderiam ter resultados diferentes. (TORRES, Ricardo Lobo. Tratado..., p. 436.)

${ }^{259}$ Como informa Kristin Hickman. op. cit., p. 1556 e seguintes.

${ }^{260}$ O julgamento do caso Boeing Co. v. United States, 123 S. Ct. 1099, 1107 (2003) demonstra que a suprema corte norte-americana ainda discute os critérios de interpretação e deferência a ser atribuída à regulamentação fiscal. Nesse caso, a corte fundamentou o seu julgamento no caso Cottage Savings Ass v. Comissioner 499
} 
Enquanto o conteúdo do artigo 37 da Constituição Federal parece aceitar relações de conformidade e compatibilidade entre as normas regulatórias editadas por entes da Administração Pública e a lei, o artigo 150, I permite apenas e tão somente uma relação de conformidade entre a regulamentação fiscal editada pela Administração Tributária e os termos da lei.

No Direito Tributário, a lei deve buscar a instituição de especificações suficientes para que o artista possa pintar o quadro desejado, definindo as ferramentas a serem utilizadas (e.g., o material da moldura, o tamanho da moldura, as cores do quadro, a qualidade da tinta, etc.). No Direito Administrativo, a lei também pode determinar que o artista pinte o quadro buscado em um certo estilo, sem previamente delimitar as especificações desse ou as ferramentas a serem utilizadas, ${ }^{261}$ não estando limitada a relações de conformidade, com alto grau de especificação.

A experiência do Direito Administrativo de habilitação da Administração Pública (como o Banco Central, a CVM, o DNC, a Comissão Central de Preços, etc.) para produzir normas regulatórias serve para demonstrar que o fato de o Poder Executivo editar normas em uma relação de conformidade ou compatibilidade com a lei não constitui uma violação do princípio da distribuição de funções/separação de poderes.

Pode-se afirmar que, na área tributária, o exercício pela Administração Tributária do poder de editar regulamentação intra legem, em uma relação de estrita conformidade com a lei constitui a aplicação do princípio da distribuição de funções/separação de poderes. $\mathrm{O}$ fato de ter sido atribuída uma importância maior à regulamentação tributária mais recentemente não constitui per se uma violação a tal princípio, em virtude das

U.S 554 (1991), julgamento que faz referência ao caso National Muffler Dealers Ass'n, Inc. v. United States, 440 U.S. 472 (1979), que adota a razoabilidade como critério de deferência.

${ }^{261}$ No Direito Administrativo, defende-se que a legalidade não deve ser aplicada de forma mecânica, de uma maneira fria, sem se considerar a finalidade pública que se persegue, exigindo-se, portanto, uma interpretação sistemática e teleológica do sistema jurídico. É o que se depreende das palavras de Romeu Bacellar Filho: “Afeiçoado à visão da legalidade a qualquer custo, com desconsideração a outros valores (como, por exemplo, o contido no princípio da confiança), o Administrador atuou, por muito tempo, coberto pelo manto da incontestabilidade do interesse público. É verdade que não se trata de inovação propriamente dita, mas de recepção dos reclames da doutrina que construiu, desde cedo, vias alternativas para elidir a aplicação mecânica da legalidade. Implementou-se, assim, o princípio da finalidade pública segundo o qual, na estipulação pela lei, de competências ao Administrador Público, tem-se em foco um determinado bem jurídico que deva ser suprido. Na apreciação da legalidade de um ato administrativo, é imperioso o exame da observância do escopo legal originário.” (BACELLAR FILHO, Romeu. Princípios de Direito Administrativo 
mesmas razões que justificam o não atropelo ao princípio da legalidade tributária, debatidas no capítulo anterior. Apesar disso, é inegável que essa maior importância da regulamentação tributária aumenta a concentração de poder no Executivo, com o risco de ser imposta ao contribuinte regulamentação fiscal opressora.

\section{III.C Reequilíbrio de Poderes/Funções}

A consequente e maior importância da regulamentação tributária, diante da flexibilização do princípio da legalidade tributária, acarreta uma maior concentração de poder nas mãos do Executivo, o que não constitui por si só uma violação ao princípio da distribuição de funções/separação de poderes, como já demonstrado acima tanto nos Estados Unidos como no Brasil. A experiência brasileira conta ainda com o caso dos tribunais do trabalho que detiveram amplo poder normativo para dirimir dissídios coletivos até a Emenda Constitucional n. 45/2004, o que demonstra que uma maior concentração de poder em um mesmo órgão não é suficiente por si só para violar o princípio da distribuição de funções.

Nesse particular, é de suprema importância ter em mente que o fato de a regulamentação tributária ter um papel mais relevante no ordenamento jurídico não significa que essa passe a ter o mesmo status jurídico de lei, ou passe a estar integrada na lei. A lei e o regulamento continuam sendo instrumentos normativos independentes, de hierarquia distinta. Canotilho afirma com precisão que

é um princípio de grande relevância no caso de reenvios normativos da lei para a administração no sentido de esta executar ou complementar os seus preceitos. Sempre que a lei autoriza ou habilita a administração a complementar ou executar os seus preceitos, isso não significa a elevação dos regulamentos ao estalão legislativo, pois tal é expressamente proibido pelo princípio da tipicidade das leis (cfr. Art. 115.o/5). Daí que: (a) a norma regulamentar executora ou complementar continue a ser uma norma separada e qualitativamente diferente da norma legal, pois a norma legal reenviante não incorpora o conteúdo regulamentar nem lhe pode atribuir força legal; (b) ambas as normas mantenham a natureza e hierarquia respectivas, não se verificando qualquer fenómeno de integração. ${ }^{262}$

e Tributação: Fronteiras e Implicações. Revista Trimestral de Direito Público, São Paulo, Malheiros, n. 38, p. 30-36, 2002).

${ }^{262}$ CANOTILHO, J.J. Gomes. Direito Constitucional. 6. ed. rev. Coimbra: Almedina, 1993. p. 915-916. 
No caso de a Administração Tributária editar regulamentação físcal em descompasso com a Constituição Federal ou com a lei, o contribuinte continua tendo acesso ao Poder Judiciário, que deverá conhecer e julgar o seu pleito.

A questão dos limites da revisão judicial diante do poder regulamentar do fisco em um contexto de flexibilização do princípio da legalidade tributária passa então a ser o desafio dos operadores do Direito.

Quando se discutem juízos de legalidade, o controle judicial da atividade regulamentar é pleno, como já explicado no Capítulo I, que trata do princípio da legalidade.

Não obstante, quando há reenvios normativos ou quando a regulamentação tributária intra legem envolve juízos de legalidade e também abrange uma função tipificante limitada, com a coleta de dados em concreto, a possibilidade de controle judicial da regulamentação continua a existir, mas o foco desse controle vai deixando de ser a regulamentação fiscal em si mesma, e vai sendo substituído pelo modo como a referida regulamentação foi editada. Ou seja, o processo de edição da regulamentação vai se tornando mais importante, devendo também ser objeto de revisão judicial.

A ampliação da possibilidade de revisão judicial constitui uma medida de reequilíbrio de funções/poderes que o contexto exige. À medida que o poder regulamentar vai aumentando, com a flexibilização da lei, deve-se permitir o Judiciário de realizar uma revisão mais profunda na atividade regulamentar, munindo-o com instrumentos para tanto, como o processo a ser discutido a seguir.

Um exemplo ajuda a compreender: após o Executivo fixar na regulamentação tributária que uma determinada atividade tem o grau de risco grave para fins da fixação da alíquota do SAT, o contribuinte provavelmente não teria o seu pleito individual acolhido judicialmente para reconhecer que a mesma atividade, só que por ele conduzida e diante dos seus investimentos feitos em segurança, tem o grau de risco médio, tendo em vista que isso implicaria a distorção da norma fixada na lei e completada por regulamento. O Poder Judiciário provavelmente entenderia que, para estabelecer em uma ação judicial individual uma alíquota inferior àquela aplicável segundo a classificação de risco da atividade na 
regulamentação, ele atuaria como legislador/regulamentador positivo, ${ }^{263}$ com a instituição de uma situação de desigualdade diante de outras empresas que conduzem a mesma atividade (e que também podem ter feito investimentos relevantes em segurança).

Por outro lado, o contribuinte poderia discutir no Judiciário o modo como a atividade econômica foi enquadrada como de risco grave, argumentando, por exemplo, que os investimentos por ele realizados não foram levados em consideração, que o Executivo atuou de forma arbitrária ao enquadrar a atividade como de risco grave, que o Executivo não analisou o universo efetivo de empresas naquela atividade, que os critérios técnicos usados no referido enquadramento estavam equivocados (e.g., levaram-se em consideração os acidentes realizados no transporte dos empregados entre suas residências e a empresa), que o resultado da regulamentação acarreta violação de direitos fundamentais, que a regulamentação em vigor está obsoleta, etc.

Contudo, a possibilidade de discutir as questões acima no Poder Judiciário é dificultada na atualidade em virtude da ausência de um processo formalizado para edição da regulamentação fiscal que fixa a alíquota do SAT, mas é exatamente aqui onde se encontra a importância do reconhecimento da necessidade de reequilíbrio de funções/poderes mencionado acima, com a ampliação da revisão judicial.

É claro que podem existir casos de ilegalidade evidente em que a atividade tipificante limitada conduzida pela Administração Tributária distorce tanto a realidade que permite ao juiz afastar de plano a regulamentação editada, apesar de ser seu papel completar a lei.

Muito embora ainda não existam muitos casos sobre a discussão dos limites da revisão judicial nessas hipóteses, cumpre mencionar o acórdão proferido pelo Superior Tribunal de Justiça no julgamento do Recurso Especial n. 1.000.302-RS, decidido no dia 12.05.2009 (DJU de 27.05.2009), que trata exatamente de um processo envolvendo a contribuição SAT e dos limites do controle judicial.

${ }^{263}$ Sobre a impossibilidade de o Poder Judiciário atuar como legislador positivo, vide, como exemplo, o seguinte acórdão prolatado pelo Supremo Tribunal Federal: Ag. Reg. no Recurso Extraordinário n. 318.873-9 (Segunda Turma; julgamento: 12.11.2002; DJU 19.12.2002). 
O recorrente interpôs recurso especial diante do acórdão prolatado pelo Tribunal Regional Federal da $4^{\mathrm{a}}$ Região que decidiu que a alíquota do SAT é graduada pela lei segundo o grau de risco da atividade em geral, e não diante do risco efetivo existente em cada uma das empresas. Diante do recurso especial interposto, o Ministro Castro Meira proferiu voto no sentido de que o Poder Judiciário não poderia rever o enquadramento da atividade do recorrente como de risco grave pelo Executivo, o que impediu a revisão judicial da forma como o poder normativo do fisco foi exercido.

O Ministro Mauro Campbell Marques, ao proferir voto-vista, reconheceu que, muito embora o Executivo tenha o poder de classificar o grau de risco das atividades econômicas, tal atividade classificatória deve ser efetivamente realizada pela Administração Tributária, sob pena de a regulamentação se tornar arbitrária. Para esse julgador, o limite da intervenção do Poder Judiciário no caso seria determinar a realização de inspeções pelo Executivo para que se reenquadrasse, se o caso, o nível de risco da atividade do recorrente, tendo em vista que o Executivo não realizava tal avaliação há anos. $^{264}$ Para ele, o Poder Judiciário não poderia reenquadrar especificamente a atividade do contribuinte em juízo, pois tal medida violaria o princípio da distribuição de funções/separação de poderes.

O raciocínio acima do Ministro Campbell comprova que a flexibilização do princípio da legalidade tributária não significa que a Administração Tributária está livre para preencher em regulamentação os conceitos indeterminados utilizados em lei na forma e no momento que lhe convier. O controle judicial do modo e do tempo do exercício do poder normativo pelo fisco deve ser exercido para evitar a utilização inadequada do poder regulamentar pelo Executivo, como forma de observação do princípio da distribuição de funções/separação de poderes.

\footnotetext{
${ }^{264}$ A esse respeito, é importante ter em mente os seguintes detalhes envolvendo a contribuição SAT: (i) o Decreto n. 6.042/2007 deixou claro que quem estabelece o grau de risco das atividades é o Ministério da Previdência e Assistência Social, sendo que o contribuinte é responsável pelo seu enquadramento em uma determinada atividade (e não no grau de risco, como dispunha a redação anterior do parágrafo 5 do artigo 202 do Decreto n. 3048/1999 - "Regulamento da Previdência Social - RPS"); e (ii) o contribuinte pode pleitear e o Ministério da Previdência pode alterar o enquadramento da sua empresa de forma individual, a fim de reduzir a alíquota do SAT, desde que sejam cumpridos certos requisitos, conforme dispõe o artigo 203 do RPS. Dispositivos dessa natureza, que permitem o contribuinte pleitear a aplicação da lei de forma individual diante da sua realidade (e fora, portanto, do âmbito da atividade tipificadora limitada conduzida pela Administração Tributária) são saudáveis, eis que normalmente se coadunam com o princípio da capacidade contributiva e podem também ser compatíveis com outros princípios específicos aplicáveis ao tributo sob análise (como, por exemplo, a própria finalidade da contribuição SAT, de promover a segurança no trabalho).
} 
Cabe lembrar também que o artigo 49, V da Constituição Federal atribui competência ao Congresso Nacional para sustar os atos normativos do Poder Executivo que exorbitem os limites do poder regulamentar ou a delegação legislativa. Ou seja, o Congresso Nacional também deve realizar um controle de legalidade da regulamentação. Apesar de não se ter notícia da utilização do referido dispositivo pelo Congresso Nacional na área tributária, ${ }^{265}$ esse mecanismo disponível ao Poder Legislativo constitui, ao lado da revisão judicial, outro importante meio de controle do exercício do poder normativo pela Administração Tributária e de proteção da segurança jurídica.

Com a flexibilização da legalidade tributária, o Congresso Nacional deve passar a fiscalizar de forma próxima e cautelosa como o Poder Executivo exerce o poder regulamentar tributário para, se o caso, sustar a regulamentação produzida. A participação efetiva dos congressistas na edição de lei ou na conversão de medida provisória em lei continua sendo uma atividade fundamental, mas o Congresso Nacional deve perceber que, com os limites inerentes à lei tributária, o seu papel somente será inteiramente cumprido se for verificado que a lei foi devidamente regulamentada pela Administração Tributária, sob risco de a intenção dos representantes do povo, materializada em lei, ser posteriormente distorcida na regulamentação. É necessário que esse mecanismo seja efetivamente utilizado com a expedição dos competentes decretos legislativos.

Observe-se que o artigo 49, V da Carta Magna trata de "atos normativos" em geral do Poder Executivo, o que, na nossa visão, abarca a regulamentação tributária em geral, não se limitando aos regulamentos em sentido estrito.

Mesmo com a possibilidade de sustação dos atos normativos do Executivo pelo Congresso Nacional e de revisão pelo Poder Judiciário, a flexibilização do princípio da legalidade tributária reclama uma maior proteção do contribuinte, já que, em algumas ocasiões, pode não ser claro se a Administração Tributária operou conforme à Constituição

${ }^{265}$ O Senador Álvaro Dias apresentou o Projeto de Decreto Legislativo n. 10/2008, o qual pretendia sustar os Decretos n. 6.339 e 6.345 , ambos de 2008, que aumentaram as alíquotas do imposto sobre operações financeiras ("IOF"), diante da extinção da contribuição provisória sobre movimentação financeira ("CPMF"). A Comissão de Constituição, Justiça e Cidadania do Senado Federal entendeu que os decretos foram editados dentro da competência regulamentar do Presidente da República e que não seria função do decreto legislativo o controle constitucional dos decretos sob exame. Sem entrar no mérito da questão e da decisão da referida 
Federal e à lei ao exercer o poder regulamentar. ${ }^{266}$ Essa maior proteção do contribuinte pode ser alcançada por meio de um reequilíbrio de funções/poderes, com a instituição de novos mecanismos jurídicos de proteção, aptos a permitir o controle pleno da regulamentação tanto pelo Congresso Nacional quanto pelo Poder Judiciário, como o processo estudado no presente trabalho.

Comissão, certo é que a iniciativa do Senado é louvável, devendo o exercício do poder regulamentar pelo Executivo ser fiscalizado de forma constante pelos componentes do Congresso Nacional.

${ }^{266}$ DUARTE, David. A Norma de Legalidade Procedimental Administrativa..., p. 800. 


\section{CAPÍTULO IV - PARTICIPAÇÃO DO CONTRIBUINTE NA EDIÇÃO DA REGULAMENTAÇÃO TRIBUTÁRIA}

\section{IV.A A Flexibilização da Legalidade Tributária e a Necessidade do Processo Regulamentar}

Diante de uma complexa realidade em que a lei deixa de ter a mesma força de contenção da Administração Tributária de outrora, o operador do Direito Tributário se encontra em conflito à medida que percebe que o tradicional e idolatrado instrumento de proteção da liberdade e da segurança jurídica perde, na atualidade, o seu vigor original. $O$ conflito decorre do sentimento de que o princípio da legalidade tributária não consegue mais determinar, em alguns casos, como a Administração Tributária se comportará diante de uma dada situação concreta, sendo que às vezes a própria lei dá margem indevida de atuação normativa ao fisco, como ocorreu com o comentado artigo 27 da Lei n. $10865 / 2004$.

Essa crise se agrava em razão da utilização de medidas provisórias pelo Executivo e dos casos de produção de regulamentação tributária opressora (ou omissão da regulamentação fiscal), como demonstrado por meio de exemplos no Capítulo II. Cria-se uma circularidade normativa em volta do Executivo, na qual o risco de opressão do contribuinte passa a ser muito alto. ${ }^{267}$

Muito embora o contribuinte possa reagir contra uma regulamentação fiscal opressora no Poder Judiciário, nada pode ele fazer para evitar a sua edição e o litígio. Os controles da regulamentação fiscal realizados pelo Legislativo e pelo Judiciário comentados no capítulo anterior são repreensivos, mas não preventivos.

\footnotetext{
${ }^{267}$ Por essa razão, Tércio Sampaio Ferraz Jr. afirma que: “(...) sempre que o Executivo, com relação a determinados conteúdos e sob certas condições, estiver autorizado pela Constituição a emanar normas com força de lei (decreto-lei, medida provisória), excluída estará a sua competência regulamentar inominada. Por exemplo, admitida a competência para editar normas com força de lei sobre certas matérias, o Executivo não pode regulamentá-las por delegação inominada, só cabendo aí o regulamento de execução nos limites do dispositivo legal (regulamentação para fiel execução, privativa do Presidente da República).” (FERRAZ, Jr., Tércio Sampaio. O Poder Normativo das Agências Reguladoras à Luz do Princípio da Eficiência. In: ARAGÃO, Alexandre Santos (coord.) O Poder Normativo das Agências Reguladoras. Rio de Janeiro: Editora Forense, 2006, p. 279).
} 
Diante de tal realidade, o operador do Direito tende a se agarrar ao princípio da legalidade tributária e acaba olvidando que a lei propriamente dita, em razão da linguagem, pode conter em si mesma uma limitação técnica, não constituindo mais um mecanismo de segurança totalmente eficaz. ${ }^{268}$ Em algumas situações, a própria lei faz um reenvio à regulamentação tributária, deixando para a última um papel que deveria ter sido efetivamente cumprido pela lei.

Logo, sem deixar de celebrar a posição daqueles que continuam a pregar a utilização exclusiva de conceitos determinados na lei tributária sem reenvios à regulamentação, o que, sem dúvida alguma, constitui um mecanismo de garantia mais forte, deve-se reconhecer a necessidade de discussão dos meios de prevenção de controvérsias com o fisco. ${ }^{269}$ Importantes estudos já foram produzidos sobre os mecanismos alternativos de solução de controvérsias no campo tributário, ${ }^{270}$ mas também devem ser pensados e considerados meios de prevenção dessas controvérsias.

Para tanto, é fundamental lembrar que o princípio da legalidade tributária não se encontra isolado no sistema jurídico, constituindo uma espécie de legalidade dentro do Estado de Direito, que também abarca a legalidade genérica (artigo $5^{\circ}$, II da Constituição Federal), a legalidade administrativa (artigo 37 da Carta Magna) e outros princípios que protegem os direitos fundamentais do contribuinte. A crise que desencadeou a flexibilização do princípio da legalidade tributária está relacionada apenas com as limitações inerentes à lei. ${ }^{271}$ Essa crise não constitui uma libertação do fisco para que este

268 A discussão da legalidade tributária exige a discussão das crises funcionais e metodológicas do formalismo e do positivismo (ANDRADE, José Maria de. Decisões Políticas... p. 110)

${ }^{269}$ Sérgio André Rocha também se posiciona nesse sentido. (ROCHA, Sergio André. A Deslegalização no Direito Tributário Brasileiro Contemporâneo: Segurança Jurídica, Legalidade, Conceitos Indeterminados, Tipicidade e Liberdade de Conformação da Administração Pública. In: RIBEIRO, Ricardo Lodi; ROCHA, Sergio André (coord.) Legalidade e Tipicidade no Direito Tributário. São Paulo: Quartier Latin, 2008, p. 258-259.)

${ }^{270}$ A respeito dos meios alternativos de soluções de controvérsias, citam-se, como exemplos, os seguintes importantes estudos: (i) TORRES, Heleno Taveira. Transação, arbitragem e conciliação judicial como medidas alternativas para resolução de conflitos entre Administração e contribuintes - simplificação e eficiência administrativa. Revista Fórum de Direito Tributário, Belo Horizonte, Fórum, n. 2, p. 91-126, marabr/2003; (ii) SARAIVA FILHO, Oswaldo Othon de Pontes; GUIMARÃES, Vasco Branco (Org.). Transação e Arbitragem no Âmbito Tributário: homenagem ao jurista Carlos Mário da Silva Velloso. Belo Horizonte: Fórum, 2008; e (iii) SILVA, Sergio André Rocha. Meios Alternativos de Solução de Conflitos no Direito Tributário Brasileiro. Revista Dialética de Direito Tributário, São Paulo, Editora Dialética, v. 122, p. 90, 2005.

${ }^{271}$ Nesse sentido, Odete Medauar afirma que a crise da legalidade administrativa está relacionada apenas com a lei, não afetando a legalidade enquanto instrumento de garantia e de organização da Administração Pública. Para Medauar, a compreensão da legalidade não deve levar em conta apenas a lei formal, mas todos 
possa agir como bem entender, de forma obscura e sem motivar seus atos; o Estado de Direito continua a existir com o mesmo vigor e o arbítrio continua sendo inadmissível.

Nessas circunstâncias, deve-se adotar uma nova atitude diante da realidade, com a percepção da relevância atual da regulamentação tributária e com o reconhecimento da necessidade de identificação de um novo mecanismo de proteção do contribuinte e de prevenção de controvérsias, apto a assegurar um ambiente de certeza jurídica e, assim, o Estado de Direito.

\section{IV.B O Princípio da Legalidade Processual - Da Regulamentação Tributária ao Processo Regulamentar com a Participação do Contribuinte}

No cenário acima descrito, deve-se reconhecer a existência de uma legalidade ainda pouco estudada no campo tributário brasileiro, qual seja: a chamada legalidade processual. ${ }^{272}$ No âmbito tributário, a legalidade processual é uma espécie ou uma faceta da legalidade tributária, que exige que qualquer ato administrativo ou regulamentação tributária, seja precedido de um processo. O processo assegura a transparência do modus operandi da Administração Tributária, de tal modo a garantir que esta atue dentro das balizas da lei e do ordenamento jurídico, com a proteção dos direitos fundamentais do contribuinte.

Embora não tratem do processo administrativo de edição de normas pela Administração Pública (mas sim do processo na solução de casos concretos), as palavras de Odete Medauar são aplicáveis à legalidade processual relativa à produção de regulamentação fiscal:

\footnotetext{
os preceitos de um Estado Democrático de Direito. (MEDAUAR, Odete. O Direito Administrativo em Evolução..., p. 146-149).

${ }^{272}$ No direito administrativo português, David Duarte, que aprofundou o estudo da legalidade procedimental, afirma que essa é uma espécie da legalidade administrativa, nos seguintes termos: "A norma de legalidade procedimental administrativa é, assim, para além de uma norma comum a todo o exercício procedimental da função administrativa, venha o procedimental a terminar em norma ou decisão de direito privado ou norma ou decisão de direito público, uma norma de legalidade específica do procedimento ou, melhor dito, uma norma relativa à legalidade específica para o procedimento, configurando mais uma norma de legalidade especial: no caso, como se verá, uma norma especial constitutiva, dado que contém um efeito diferente do que consta da norma geral de legalidade, dentro da relação de consumpção entre previsões." (DUARTE, David. A Norma de Legalidade Procedimental Administrativa..., p. 413). Esse efeito diferente afirmado por David Duarte é a relação de compatibilidade da legalidade procedimental, em contraste com a relação de conformidade exigida pela legalidade administrativa.
} 
no vínculo legalidade-processo administrativo, este representa uma das garantias do princípio da legalidade, porque significa atuação parametrada da autoridade administrativa, em contraposição à atuação livre, mais suscetível ao arbítrio. Mesmo que exista parcela de discricionariedade em alguma fase do processo administrativo, o conhecimento dos mecanismos decisionais e dos fatos da situação, inerentes à processualidade, possibilitam direcioná-las às verdadeiras finalidades da atuação. ${ }^{273}$

Nesse passo, tendo em vista a insuficiência da lei para proporcionar a segurança jurídica em determinados casos, a "liberdade" que a Administração Tributária tradicionalmente tem na edição unilateral da regulamentação fiscal e a maior importância atribuída a esta última recentemente pelo Supremo Tribunal Federal, pode-se afirmar que a legalidade processual deve ser reconhecida no Brasil para estruturar e dar transparência às etapas percorridas entre a edição da lei tributária e a publicação da regulamentação fiscal, de tal forma a assegurar um ambiente seguro juridicamente e a possibilitar a prevenção de litígios. Desse modo, as decisões tomadas pela Administração Tributária no preenchimento de conceitos indeterminados da lei e na coleta de dados da realidade passam a se tornar, por meio do processo, transparentes e passíveis de controle. O mesmo se aplica às decisões do fisco na edição de regulamentação com fundamento em reenvios determinados por lei.

A preocupação com a relação hierárquica entre lei e regulamento deve ser ampliada para incluir também a atenção sobre a maneira como o poder regulamentar é exercido, sob a luz da lei e do ordenamento jurídico. Continua-se a se examinar a regulamentação tributária propriamente dita (resultado) diante da lei e do ordenamento jurídico, mas a legalidade processual permite que se verifique também como o poder regulamentar foi exercido (meio). ${ }^{274}$ A mera publicação da regulamentação fiscal não é mais suficiente.

Ora, à medida que a jurisprudência do Supremo Tribunal Federal e a prática vão demonstrando como a regulamentação fiscal vai ficando mais forte, com uma maior concentração de poder no Executivo, nada mais natural que a atribuição regulamentar passe a se sujeitar à disciplina processual, como uma medida de legalidade que busca a

\footnotetext{
${ }^{273}$ MEDAUAR, Odete. A Processualidade no Direito Administrativo. 2. ed. São Paulo: Editora Revista dos Tribunais, 2008. p. 91-92.

${ }^{274}$ Como demonstrado no Capítulo III, a preocupação com a maneira como o poder regulamentar é exercido, no direito administrativo e no direito tributário, é uma realidade nos Estados Unidos da América.
} 
proteção da segurança jurídica e da liberdade. ${ }^{275,276,277}$ O processo regulamentar possibilita a prevenção ao litígio e protege o contribuinte, que também deve ter legitimidade para dar início ao referido processo no caso de omissão da Administração Tributária. Esse é o contexto no qual deve ser reconhecida a legalidade processual como uma faceta ou garantia da legalidade tributária.

A experiência norte-americana demonstra que a instituição de um processo para edição de normas regulamentares é um mecanismo que pode ser utilizado para assegurar que o poder regulamentar seja bem exercido pelo Executivo. ${ }^{278}$

${ }^{275}$ A visão de que a legalidade administrativa (conformação com a lei) vai sendo substituída pela legalidade processual é defendida por Francesco Manganaro na Itália. "Poiché la norma non definisce più il contenuto sostanziale dell'attività amministrativa, l'esigenza di legalità è soddisfatta non tanto sforzandosi di determinare a priori la regola di contemperamento degli interessi, ma ponendo precise regole legislative sul modo di esercizio dell'azione amministrativa e consentendo, così, che anche il giudice possa verificare, con un giudizio a posteriori, la condotta dell'amministrazione. (...) Se la legalità non può essere più intesa come attuazione di interessi generali predeterminati dalla legge nel rispetto delle situazioni giuridiche dei privati, essa diventa regola dei modi procedurali di attuazione del potere." (MANGANARO, Francesco. Principio di Buona Fede e Attività Delle Amministrazioni Publiche. Napoli: Edizioni Scientifiche Italiane, 1995. p. 133). Tradução livre: Tendo em vista que a norma não define mais o conteúdo substancial da atividade administrativa, a exigência de legalidade é satisfeita não tanto se esforçando a determinar previamente a regra de ponderação de interesses, mas colocando precisas regras legislativas sobre o modo de exercício da ação administrativa e permitindo, assim, que também o juiz possa verificar, com um juízo a posterior, a conduta do administrador. (...) Se a legalidade não pode mais ser entendida como atuação dos interesses gerais predeterminados pela lei no respeito das situações jurídicas dos privados, essa se torna regra dos modos processuais de atuação do poder.

${ }^{276}$ Em Portugal, Mario Aroso Almeida também reconhece a importância do processo em um ambiente em que a lei não é mais suficiente para determinar como a administração pública deve se comportar. "A verdade, porém, é que a crescente tendência para a redução do conteúdo regulador das normas que disciplinam a substância da actuação administrativa, com a consequente ampliação dos espaços de conformação que o legislador deixa a cargo da Administração, para a escolha da melhor solução, levou a que se viesse a reconhecer a importância do procedimento, não só como instrumento de racionalização da actividade decisória da Administração, mas também como instrumento de legitimação da Administração enquanto aparelho que, sendo eminentemente burocrático, vai sendo cada vez mais chamado, na ausência da prédefinição legislativa dos resultados, a determinar o conteúdo da regulação dos interesses em conflito e, assim, a tomar decisões crescentemente politizadas." (ALMEIDA, Mário Aroso. Anulação de Actos Administrativos e Relações Jurídicas Emergentes. Coimbra: Almedina, 2002. p. 127-128).

${ }^{277}$ No Brasil, Onofre Alves Batista Júnior conclui pela adoção da legalidade processual, mas parece ir além ao indicar que o Legislativo deveria apenas traçar as linhas mestras de orientação no direito tributário, com a possibilidade de ponderação de interesses na esfera administrativa, argumentos esses que não compartilhamos para adoção da legalidade processual. "Ao Parlamento devem ser reservadas, inexoravelmente, as linhas mestras de orientação, o fio condutor da atuação administrativa, os pontos essenciais, as reais decisões políticas. (...) diante da impossibilidade de disciplinar todas as questões, deve o legislador se recolher tendencialmente às matérias essenciais, aos princípios norteadores; (...) Por certo, um modelo tributário mais adequado, equilibrado e justo, como contrapartida a essa necessária flexibilização, deveria reclamar uma mais intensa "procedimentalização" do processo decisório tributário na seara administrativa, que possibilitasse uma maior racionalização, legitimidade e mais ampla ponderação dos interesses em conflito." (BATISTA JÚNIOR, Onofre Alves. A "Governamentalização" do Poder de Decisão Tributário. In: SCHOUERI, Luis Eduardo (coord.) Direito Tributário - Homenagem a Alcides Jorge Costa. Volume I. São Paulo: Editora Quartier Latin, 2003. p. 426).

${ }^{278}$ Nos Estados Unidos da América, não há previsão constitucional específica da legalidade processual, que é reconhecida a partir da cláusula do devido processo legal apenas quando a regulamentação tem traços adjudicatórios, atingindo um grupo determinado de destinatários (quando se reconhece o right to be heard). 
Juan José Lavilla Rubira explica que o processo de edição da regulamentação com participação do particular, de acordo com o APA nos Estados Unidos, é um contrapeso processual obrigatório à amplíssima discricionariedade conferida às agências pelo congresso norte-americano. ${ }^{279}$ Os comentários acerca da evolução do poder normativo das agências norte-americanas tecidos no Capítulo III acima confirmam esta afirmação: desde as precursoras palavras de James M. Landis até o julgamento de Chevron, as observações de Peter Strauss sobre Chevron e também a análise do juiz Bauer sobre esse mesmo caso comprovam que somente se pode atribuir maior poder à regulamentação, inclusive a fiscal, quando está presente uma disciplina processual que assegure que o poder regulamentar seja exercido pelo Executivo de forma transparente e em conformidade com o ordenamento jurídico.

Não tem fundamento na constituição norte-americana o direito à participação na edição de regulamentação que afeta inúmeros destinatários indeterminados; quando tal direito existe, seu fundamento é com base em lei específica ou na própria regulamentação. Nos casos intermediários, em que a regulamentação não tem um caráter adjudicatório puro, mas afeta um grupo de destinatários determinável (como, por exemplo, uma indústria) e depende de dados fáticos fornecidos por esses, o direito à participação tem fundamento no devido processo legal, sendo também utilizado como base desse direito o APA. Os antigos casos em que se discutiu a base constitucional do direito à participação na edição de regulamentação nos Estados Unidos eram de índole tributária. Em Londoner v. Denver, 210 U.S. 373 (1908), o poder executivo da cidade de Denver tentava cobrar uma espécie de contribuição de melhoria dos proprietários de imóveis em certas localidades no município, onde a pavimentação das vias havia sido realizada. O legislativo havia delegado poder para o executivo identificar os contribuintes da referida contribuição e determinar a forma de cálculo e alocação da mesma entre os contribuintes, o que acarretou resultados diferentes para cada contribuinte dentro do grupo determinado. A suprema corte norte-americana decidiu, com base na cláusula do due process, que tal contribuição não poderia ser cobrada sem terem os proprietários dos imóveis sido prévia e efetivamente ouvidos a respeito da exigência da referida contribuição. Vale transcrever trecho do voto do juiz Moody: "But where the legislature of a State, instead of fixing the tax itself, commits to some subordinate body the duty of determining whether, in what amount, and upon whom it shall be levied, and of making its assessment and apportionment, due process of law requires that at some stage of the proceedings before the tax becomes irrevocably fixed, the taxpayer shall have an opportunity to be heard, of which he must have notice, either personal, by publication, or by a law fixing the time and place of the hearing." Já no caso BiMetallic Inv. Co. v. State Bd. of Equalization 239 US 441 (1915), tendo em vista que a decisão da agência do Estado do Colorado de aumentar o imposto sobre imóveis na cidade de Denver afetava de forma igual todos os contribuintes, indeterminados, independente de dados concretos, a suprema corte decidiu que os contribuintes não tinham o direito de participar na edição da norma regulatória com base na cláusula do devido processo legal.

${ }^{279}$ Rubira também indica as seguintes razões para justificar a participação do interessado na produção da regulamentação nos Estados Unidos: (i) a possibilidade de os interessados apresentarem dados técnicos, informações desconhecidas pela Administração Pública, etc.; e (ii) a legitimação democrática das normas regulamentares diante dos poderes quase legislativos das agências daquele país. (RUBIRA, Juan José Lavilla. El Procedimiento de Elaboracion de Los Reglamentos en Los Estados Unidos de America. In: VAZQUEZ, Javier Barnes (coord.) El Procedimiento Administrativo en El Derecho Comparado. Madri: Editorial Civitas, 1993. p. 341-342) 
Odete Medauar salienta a importância do APA como forma de reconhecimento da aplicação do due process of law ao processo administrativo, bem como meio de ampliação das atividades estatais sujeitas a esse processo, incluindo-se o processo regulamentar. ${ }^{280}$

Frise-se que, mesmo nos casos em que não há a obrigação de seguir a disciplina processual na edição de regulamentos fiscais (pelo fato, por exemplo, de se tratarem de regulamentos interpretativos, editados sob general authority), o fisco norte-americano adota o expediente processual como forma de melhorar a qualidade aos regulamentos tributários daquele país.

Apesar das inegáveis diferenças culturais e das distinções dos ordenamentos jurídicos, não se pode negar que a experiência processual norte-americana na edição da regulamentação tributária é importante para demonstrar no Brasil que, nos casos em que o fisco preenche a regra-matriz de incidência tributária com dados da realidade (e.g., SAT, ICMS-ST, definição de taxas de depreciação para fins do IRPJ, reconhecimento de paraísos fiscais, etc.), deve ser reconhecida a obrigação de o Chefe do Executivo e de a Administração Tributária se sujeitarem a um processo para a edição da referida regulamentação, ${ }^{281}$ como forma de se permitir a verificação de que a atuação desse poder está conforme o ordenamento jurídico. Mas não só nesses casos o processo regulamentar é necessário, como também em outras ocasiões em que a lei estabelece um reenvio à

\footnotetext{
${ }^{280}$ MEDAUAR, Odete. O Direito Administrativo em Evolução..., p. 222.

${ }^{281}$ E é exatamente essa participação do contribuinte que faz com que seja um "processo regulamentar", e não um procedimento regulamentar. Cândido Rangel Dinamarco explica, ao traçar um paralelo entre o processo civil e o processo administrativo, que é o procedimento com a participação dos interessados que caracteriza o conceito de processo na ciência moderna. Nesse sentido, Dinamarco também defende que o processo legislativo constitui efetivamente um processo, arrematando que "o direito processual estatal é a disciplina do exercício do poder estatal pelas formas do processo legalmente instituídas e mediante a participação do interessado, ou interessados." (DINAMARCO, Cândido Rangel. A Instrumentalidade do Processo. 7. ed. São Paulo: Malheiros, 1999. p. 70 e seguintes). Dinamarco, Ada Pellegrini Grinover e Antonio Carlos Araújo Cintra afirmam que o processo é um conceito que vai além do direito processual alcançando todas as atividades estatais, inclusive o processo legislativo e, desse modo, o processo regulamentar ora estudado (CINTRA, Antonio Carlos de Araújo; GRINOVER, Ada Pellegrini; DINAMARCO, Cândido Rangel. Teoria Geral do Processo. 16. ed. São Paulo: Malheiros, 2000. p. 276). O processo condiciona a formação da vontade a ele submetida. Não é obrigatória a presença de litígio para que exista processo. Exatamente por essa razão Odete Medauar afirma que processo é colaboração do interessado, com a presença do contraditório, mas independente do litígio (MEDAUAR, Odete. A Processualidade no Direito Administrativo..., p. 41 e 43). J. Cretella Júnior entende também como desnecessária a lide para a caracterização do processo administrativo, sendo necessária a presença de apenas duas partes: o interessado e a Administração Pública. Cretella Júnior adotava um conceito amplíssimo de processo administrativo, mas não chegou a prever a possibilidade de processo na edição de regulamentos em 1966 (CRETELLA JÚNIOR, J. Tratado de Direito Administrativo. Vol. VI Processo Administrativo. Rio de Janeiro: Forense, 1966. p. 20, 63 e seguintes, e 129 e seguintes). Nelson Nery Júnior defende que só há processo onde há litígio.
} 
regulamentação ou fixa um dever instrumental (com uma lei prévia que apenas determine os seus traços básicos ou mesmo apenas a partir da lei que trata da obrigação principal). Em virtude da alta concentração de poder no Executivo, a realidade certamente mostrará ao operador do Direito Tributário outras situações em que o processo regulamentar se mostrará indispensável para a certeza jurídica.

O reconhecimento da obrigação de respeito a um processo regulamentar na produção de regulamentos constitui um caminho juridicamente sustentável para a adequada proteção do contribuinte e prevenção ao litígio em um cenário em que a regulamentação fiscal vai ficando mais forte, com uma maior concentração de poder no Executivo. ${ }^{282}$ Nada obsta que, quando possível, tal processo seja também adotado na edição de regulamentação fiscal interpretativa, que envolve apenas juízos de legalidade.

Dessa maneira, o conteúdo da legalidade processual no que toca aos atos normativos é a exigência de a edição da regulamentação tributária ser precedida de um processo. A instituição de um processo permite a conferência, a partir dos atos que o compõem, de que o poder regulamentar foi ou não bem exercido. A legalidade processual também exige que se reconheça a legitimidade do contribuinte provocar o exercício do poder regulamentar com base na lei, como forma de protegê-lo da omissão intencional do fisco. A legalidade processual busca, portanto, o bom desempenho da atribuição regulamentar pela Administração Tributária, com vistas à efetividade do princípio da legalidade tributária e, por consequência, da segurança jurídica e da liberdade. Trata-se de medida de preservação do Estado de Direito brasileiro.

(NERY JUNIOR, Nelson. Princípios do Processo na Constituição Federal: Processo Civil, Penal e Administrativo. 9. ed. São Paulo: Editora Revista dos Tribunais, 2009. p. 217).

282 Adolfo Merkl admitia adoção do processo nas esferas judicial, legislativa e administrativa. Na última, contudo, Merkl aceitava apenas o processo administrativo para a edição de atos administrativos, e não para os regulamentos, sob o argumento de que a indeterminação dos destinatários dos regulamentos impedia esses de participar na produção de tais atos normativos, sendo suficiente apenas a publicação dos mesmos. (MERKL, Adolfo. Teoría General del Derecho Administrativo. Edição ao cuidado de José Luis Monereo Pérez. Granada: Editorial Comares, S.1., 2004. p. 277-281). A obra de Merkl, entretanto, é de 1927 e a evolução econômica e tecnológica da sociedade criou a necessidade de normas com traços normativos e adjudicatórios, além de condições para a participação dos destinatários na edição dos regulamentos. O direito administrativo norte-americano é a maior evidência de que é possível a participação dos interessados na edição de regulamentação, a qual deve ser justificada. 
A Administração Tributária da pessoa política titular da competência tributária para instituição do tributo, que o tenha instituído e que está apta a exercer o poder regulamentar respectivo, deve conduzir o processo de edição da regulamentação a ser editada.

Via de regra, o processo regulamentar se inicia com a proposta de regulamentação e se conclui com a publicação da sua versão final, acompanhada da respectiva motivação. Dada a variedade de temas que podem ser objeto de regulamentação tributária, as etapas do processo regulamentar podem ser organizadas de diferentes formas, incluindo diferentes atos processuais. Em todos os casos, devem estar previstas, no mínimo, as seguintes etapas: (i) a apresentação da proposta de regulamentação pelo fisco, acompanhada de uma exposição de motivos, incluindo estudos técnicos se cabível; (ii) a participação do contribuinte, ao qual se deve atribuir o direito de comentar a regulamentação tributária proposta; e (iii) a motivação da regulamentação ao final editada, na qual se devem consignar as justificações para aceitar ou rejeitar os comentários apresentados pelo contribuinte.

Diante das várias formas de aplicação da legalidade processual, David Duarte conceitua tal legalidade (chamada por ele de legalidade procedimental) nos seguintes termos:

a configuração deste princípio com este conteúdo conduz a uma norma básica sobre o modo de exercício da função: qualquer manifestação deôntica que ocorra no seu seio tem de ser antecedida por um espaço de preparação do sentido conclusivo e que, dependendo das normas aplicáveis, pode compreender os mais variados conteúdos. ${ }^{283,284,285}$

Tendo em vista que regulamentar é mais difícil do que legislar, como exposto no Capítulo II, a participação do contribuinte na edição da regulamentação tributária se mostra ainda mais importante, indo além de sua natureza de garantia. Com efeito, a

\footnotetext{
${ }^{283}$ DUARTE, David. A Norma de Legalidade Procedimental Administrativa..., p. 409.

${ }^{284}$ Em Portugal, o princípio da legalidade processual, com a exigência da audiência dos interessados está positivado na Constituição da República Portuguesa (artigo 267, n. 5). Entretanto, não há a possibilidade de o contribuinte participar do processo de edição da regulamentação tributária, mas sim de ser ouvido previamente em algumas situações concretas e específicas (MACHETE, Pedro. A Audição Prévia do Contribuinte. In: CAMPOS, Diogo Leite de (coord.). Problemas Fundamentais do Direito Tributário. Lisboa: Vislis Editores, 1999, p. 301 - 335).

${ }^{285}$ Nos Estados Unidos, existem dois tipos de processo de edição de normas regulamentares: o formal e o informal. Entretanto, a realidade fática foi além dessas duas espécies e criou processos regulamentares híbridos, diante das necessidades de cada caso e com características de cada um desses dois tipos de processo.
} 
participação do contribuinte na edição da regulamentação fiscal permite que a Administração Tributária tenha acesso a informações e a pontos de vista que ela não teria se atuasse de forma unilateral, sem a colaboração do contribuinte. A "norma espelho" do contribuinte, comentada anteriormente, passa a ser dividida com o fisco. Dessa forma, a Administração Tributária ganha ao ter uma percepção mais precisa da realidade e de como a regulamentação proposta provavelmente será aplicada, podendo ajustá-la com o escopo de melhorar a sua qualidade e viabilizar a sua aplicação na forma devida em conformidade com o ordenamento jurídico, evitando-se litígios.

A participação do contribuinte permite que ele colabore na produção da regulamentação tributária para que se alcance um resultado de melhor qualidade. Diante da proposta de regulamentação de um dado tema, o contribuinte pode provocar a Administração Tributária a: (a) observar os termos da lei e a respeitar os direitos fundamentais do contribuinte; (b) tratar, na regulamentação, de hipóteses não consideradas originalmente; (c) considerar aspectos técnicos e práticos não levados em consideração pela Administração Tributária; (d) demonstrar, com clareza e de forma explícita, a razão pela qual o fisco pretende regulamentar uma matéria de um certo modo, o critério eleito, etc.; (e) adotar, para situações equivalentes, tratamento isonômico; (f) explicar os motivos do conteúdo de um dado dispositivo regulamentar diante dos termos da lei, de modo a permitir a verificação do caráter inventivo ou não do referido dispositivo infralegal; (g) justificar a instituição de um dever instrumental, tendo em vista alternativas que alcançam o mesmo objetivo de forma mais econômica; etc.

Os componentes da Administração Tributária, da mesma forma que o contribuinte ou seus representantes, são seres humanos com conhecimento finito, havendo sempre a possibilidade de uma falha na edição da regulamentação, o que constitui mais uma justificativa para a participação do contribuinte no processo regulamentar. No mesmo sentido das afirmações de James Madison as quais abrem este trabalho, pode-se afirmar que a Administração Tributária também é de certo modo um reflexo da natureza humana e, consequentemente, sujeita a falhas, valendo a pena, dessa maneira, a abertura de um diálogo com o contribuinte no processo de edição da regulamentação tributária.

Ademais, a possibilidade de a Administração Tributária ajustar a regulamentação proposta diante de comentários do contribuinte, acompanhada dos motivos pelos quais os 
comentários apresentados foram aceitos ou rejeitados, dará maior transparência da posição do fisco acerca do conteúdo da regulamentação. Dependendo dos motivos utilizados, o processo regulamentar proporcionará maior legitimidade à regulamentação editada e, consequentemente, maior aceitação dessa, evitando-se litígios. Tudo isso, obviamente, deve contribuir para a melhora da percepção da Administração Tributária pelo contribuinte.

O processo regulamentar devidamente documentado em autos (físicos ou digitais) permitirá que a eventual revisão judicial da regulamentação fiscal ao final editada, do modo como essa foi produzida e dos seus motivos, seja realizada de forma plena.

Aliás, em nada se alterará a possibilidade de revisão judicial dos atos da Administração Tributária, mas, quando se tratar de questionamento acerca do preenchimento de conceitos indeterminados pelo fisco com dados em concreto ou casos de reenvio à regulamentação, o foco do controle judicial provavelmente passará a ser a forma como o poder regulamentar foi exercido, como indicado acima.

Cabe ainda lembrar que a ideia de que o ato administrativo concreto deve ser precedido de um processo específico decorre de uma sucessão de eventos ao longo do tempo, não tendo sido sempre uma questão pacífica. Nesse campo, o Direito Tributário, o Direito Administrativo disciplinar e a legislação sobre as licitações foram pioneiros, dada a necessidade de proteção do particular diante da Administração Pública.

Atualmente, é tranquilo que qualquer ato administrativo ou tributário concreto deve ser precedido de um procedimento ou processo, sendo evidência desse entendimento comum o Decreto n. $70.235 / 72$, a Lei n. $9.784 / 99$ e a Lei n. 10.177/98 do Estado de São Paulo. Ninguém ousaria afirmar hoje que não haveria a necessidade de um procedimento ou processo administrativo para demissão de um servidor público, para a lavratura de um auto de infração ou para discussão desse na esfera administrativa. ${ }^{286,287}$ Da mesma forma,

\footnotetext{
286 Odete Medauar indica a tendência de na atualidade se "deslocar a atenção, no estudo do ato administrativo, ao seu conteúdo, ao modo de sua formação, ao procedimento das escolhas nele sintetizadas." (MEDAUAR, Odete. O Direito Administrativo em Evolução..., p. 205.)

${ }^{287}$ Carlos Ari Sundfeld relata como a ideia de processo administrativo em casos individuais foi sendo absorvida paulatinamente na doutrina de direito administrativo pátrio. (SUNDFELD, Carlos Ari. Processo e Procedimento Administrativo no Brasil. In: SUNDFELD, Carlos Ari; MUÑOZ, Guillermo Andrés (coord.)
} 
espera-se que, com a evolução da doutrina, jurisprudência e legislação sobre o tema, seja reconhecido com tranquilidade no futuro que a regulamentação tributária deve ser precedida de um processo, nos termos aqui discutidos.

Cumpre também esclarecer que a participação do contribuinte no processo de edição da regulamentação tributária não pretende recuperar a ideia de consentimento à tributação, ideia essa que enfraqueceu com o desenvolvimento do Estado Social e Democrático de Direito. Ou seja, essa participação não tem como escopo resgatar e fortalecer o "de acordo" direto do contribuinte à imposição ou majoração de tributos no Estado de Direito por meio de lei, situação essa que talvez tenha apenas existido de forma ideal ou em pequenas comunidades.

Nada mais natural, tendo em vista que essa participação se daria em nível infralegal, com âmbito exclusivamente técnico-jurídico, e não visaria a constituir um mecanismo de participação direta do contribuinte nas decisões do Legislativo ou Executivo sobre a instituição ou majoração de tributos. ${ }^{288,289}$ A discussão dentro do bojo do processo regulamentar não deve ser uma arena para disputa de interesses de grupos de contribuintes, mas sim um ambiente de discussão técnica, focada na melhoria da regulamentação fiscal.

Para fechar, tendo em vista um ambiente em que a lei isoladamente não mais proporciona a certeza jurídica almejada, espera-se que o reconhecimento da legalidade processual e a adoção de processos regulamentares viabilizem a produção de normas infralegais de melhor qualidade, proporcionando maior segurança jurídica, aplicação isonômica da lei de forma efetiva, evitando-se, assim, a distorção ou o atropelo de conceitos jurídicos e a edição de regulamentação tributária arbitrária, com uma menor

As Leis de Processo Administrativo - Lei Federal 9.784/99 e Lei Paulista 10.177/98. São Paulo: Malheiros, 2000. p. 20 e seguintes).

${ }^{288}$ José Casalta Nabais toca nesse assunto ao afirmar que a proibição do referendo fiscal decorre do receio de atitudes egoístas do contribuinte e dos debates demagógicos que seriam envolvidos na discussão do referendo. Apesar disso, Casalta Nabais defende a possibilidade do referendo fiscal como forma de se resgatar a ideia de autotributação, desde que as cautelas devidas sejam adotadas. (NABAIS, José Casalta. $O$ Dever Fundamental.,. p. 422-434.

${ }^{289}$ Paulo Otero também trata da questão apontando os riscos de se atribuir voz ao povo, à maioria sobre temas sensíveis ao Estado como o tributo. "Desde logo, a maioria não é critério de verdade ou, se se pretender, não traduz a garantia de uma 'consciência jurídica geral' justa, antes o princípio maioritário conhece sempre limites: a eventual aprovação maioritária por deliberação parlamentar ou por referendo dos crimes de genocídio contra os judeus praticados pela Alemanha Nazi ou pela Rússia estalinista, tal como as 'limpezas étnicas' cometidas já na década de noventa na ex-Iugoslávia, nunca tornaria tais actos menos odiosos ou mais legítimos”. (OTERO, Paulo. Legalidade e Administração Pública. ., p. 413.) 
quantidade de litígios. Isso restaurará a possibilidade de proteção adequada e preventiva do contribuinte diante da flexibilização da legalidade tributária e da maior concentração de poder no Executivo, com a devida manutenção do Estado de Direito brasileiro.

\section{IV.C Outros Fundamentos para Participação do Contribuinte na Edição da Regulamentação Tributária}

Além da legalidade processual, que constitui o princípio fundamental para o reconhecimento do direito ao processo regulamentar com a participação do contribuinte, deve-se abordar também outros princípios que dão sustentação a esse processo. É o que se passa a fazer.

\section{IV.C.1 Princípio do Devido Processo Legal}

O artigo $5^{\circ}$, LIV da Constituição Federal dispõe que "ninguém será privado da liberdade ou de seus bens sem o devido processo legal." O princípio do devido processo legal, em sua acepção processual que aqui interessa, assegura a disciplina processual como forma de efetivo acesso à justiça, com a possibilidade do contraditório e da mais ampla defesa, com vistas a proteger o particular do eventual arbítrio da Administração Pública. ${ }^{290}$ Dessa maneira, qualquer atividade da Administração Pública que tenha como efeito a privação da liberdade ou da propriedade deve estar sujeita à disciplina processual.

A esse respeito, é importante perceber que a atividade desempenhada pela Administração Tributária na coleta de dados da realidade e da sua utilização para o preenchimento de conceitos indeterminados utilizados em lei não tem cunho puramente normativo, mas tem traços marcantes de uma atividade adjudicatória. Com efeito, a captação de dados concretos com a finalidade de completar conceitos indeterminados utilizados em lei exige uma decisão da Administração Tributária, que afetará um

\footnotetext{
${ }^{290}$ Sobre a origem do princípio do devido processo legal, em seu caráter processual (incluindo o direito de ser ouvido e de oferecer e produzir provas), e sua posterior evolução, ganhando natureza substantiva, na Inglaterra e nos Estados Unidos da América, vide, dentre outras: DÓRIA, Antonio Roberto Sampaio. Princípios Constitucionais Tributários e a Cláusula "Due Process of Law”. São Paulo: Revista dos Tribunais, 1964; GRINOVER, Ada Pellegrini. Os Princípios Constitucionais e o Código de Processo Civil. São Paulo: Bushatsky, 1975. p. 8 e seguintes; BOTTALLO, Eduardo Domingos. Curso de Processo Administrativo Tributário. 2. ed. São Paulo: Malheiros, 2009. P. 40; e NERY JUNIOR, Nelson. Princípios do Processo na Constituição Federal: Processo Civil, Penal e Administrativo..., p. 84 e seguintes. O devido processo legal também é visto como uma garantia do próprio processo.
} 
determinado grupo de contribuintes. ${ }^{291}$ A decisão que objetiva a complementação da norma envolve a qualificação de dados fáticos dentro dos conceitos legais, bem como a prévia interpretação destes últimos. ${ }^{292}$ Como essa atividade híbrida desempenhada pelo fisco acarretará inevitavelmente a privação de bens por meio da exigência do tributo, é necessário que ela seja conduzida em um processo, de tal modo que todas as etapas envolvidas entre a edição da lei até a publicação da regulamentação fiscal relevante sejam transparentes.

Um exemplo ajuda a ilustrar: imagine-se o fisco de uma determinada unidade da federação determinando a margem de valor agregado de mercadorias de um certo setor da economia para fins do ICMS-ST. Como o ICMS é um imposto estadual, pode-se afirmar que o fisco deve levantar o preço final dessas mercadorias, por exemplo, a partir de uma média obtida a partir de pesquisa no varejo nas principais cidades do Estado, assumindo que nessas se encontra a maior parte do mercado ativo (99\%). Entretanto, com o escopo de fixar a margem de valor agregado a mais alta possível, o fisco opta por conduzir tal pesquisa apenas na capital do Estado, onde os maiores preços são praticados. A margem de valor agregado acaba então sendo fixada em percentual superior à média real. Em razão disso, os pequenos industriais do interior do Estado, que não fornecem para o varejo da capital, acabam recolhendo o ICMS-ST com base em uma margem de valor agregado que jamais se concretiza, hipótese na qual fica clara a privação indevida de um bem de tais contribuintes, lembrando também que o Supremo Tribunal Federal decidiu que não há direito ao ressarcimento de ICMS-ST quando o preço praticado foi inferior àquele determinado conforme a legislação estadual. ${ }^{293}$ Ou seja, a elaboração da regulamentação fiscal pode acarretar uma privação indevida de recursos financeiros.

\footnotetext{
${ }^{291}$ É muito diferente, por exemplo, de um inquérito policial, onde nenhuma decisão é tomada, sendo apenas um procedimento de cunho investigatório. Mesmo assim, a Primeira Turma do Supremo Tribunal Federal reconheceu a presença de direitos fundamentais do indiciado que devem ser respeitados no inquérito, no julgamento do Habeas Corpus 82.354-8 Paraná (julgamento: 10.08.2004; DJU: 24.09.2004).

${ }^{292}$ É uma situação muito similar à questão da qualificação como problema conceitualmente autônomo do da interpretação dos tratados de dupla tributação. Nesse sentido, Alberto Xavier reconhece que a interpretação é um fenômeno independente da aplicação/qualificação. (XAVIER, Alberto. Direito Tributário Internacional do Brasil. 6. ed.. Rio de Janeiro: Forense, 2004. p. 190 e seguintes). No mesmo sentido, Rodrigo Maitto da Silveira (SILVEIRA, Rodrigo Maitto. Aplicação de Tratados Internacionais contra a Bitributação Qualificação de Partnership Joint Ventures. Série Doutrina Tributária. Vol. I. São Paulo: Quartier Latin, 2006. p. 48). Heleno Torres denomina de função qualificadora da Administração Tributária o processo de positivação das normas tributárias, dentro do qual entendemos estar a produção da regulamentação fiscal (TORRES, Heleno. Direito Tributário e Direito Privado: Autonomia Privada : Simulação : Elusão Tributária. São Paulo: Editora Revista dos Tribunais, 2003. p. 85.)

${ }^{293} \mathrm{Na}$ Ação Direta de Inconstitucionalidade n. 1.851-4 Alagoas, comentada no Capítulo II, o Supremo Tribunal Federal decidiu que o fato gerador presumido do ICMS-ST é definitivo e que não dá ensejo à
} 
O exemplo sobre a contribuição SAT, comentado no Capítulo III (item III.C), também demonstra essa perigosa situação.

Dessa maneira, a fim de assegurar que não ocorra uma indevida privação de bens e direitos por meio do tributo, quando presente uma atividade tipificante limitada da Administração Tributária, a edição de regulamentação fiscal envolvendo a coleta de dados em concreto e questões técnicas deve ser conduzida em um processo, em observação ao princípio do devido processo legal. É o processo que permite a avaliação da conformidade do modo de edição da regulamentação fiscal com o ordenamento jurídico.

Isso é confirmado ainda pelo fato de que, depois da complementação dos conceitos indeterminados utilizados em lei pela Administração Tributária, o Poder Judiciário poderá se entender como não legitimado a intervir na norma ao final construída, sob pena de estar agindo como um legislador ou regulamentador positivo. No exemplo acima, seria improvável a atuação do Poder Judiciário para substituir a margem de valor agregado constante da norma ao final editada pelo fisco pela margem apontada pelo contribuinte como correta, sem que haja discussão sobre a forma como a margem foi fixada.

É importante registrar que a presença do devido processo legal no âmbito do processo regulamentar implica a obrigatoriedade de respeito ao contraditório, assegurado de forma expressa pela Carta Magna em dispositivo específico, de tal sorte que a Administração Tributária deve ser transparente na proposta de uma regulamentação, que deve vir acompanhada de uma exposição de motivos e dos estudos técnicos respectivos. ${ }^{294}$ Do mesmo modo, deve ser observado o princípio de publicidade dos atos processuais e dos atos da Administração Pública.

\footnotetext{
"restituição ou complementação do imposto pago, senão, no primeiro caso, na hipótese de sua não-realização final."

${ }^{294}$ Um caso relevante nos Estados Unidos é o United States v. Nova Scotia Food Products Corp., United States Court of Appeals, Second Circuit, 1977, 568 F.2d 240. Nesse caso, o interessado conseguiu o reconhecimento no poder judiciário da invalidade de uma norma regulatória editada pela Food Drug Administration, em virtude de essa agência não ter tornado público um estudo técnico que havia sido utilizado como base para edição do regulamento. Não foi aberto o contraditório com relação a tal estudo. Nesse caso, o poder judiciário decidiu que a agência tinha a obrigação de ventilar os principais fundamentos da regulamentação (incluindo a discussão sobre o estudo técnico), muito embora não estivesse obrigada a discutir cada item ou argumento levantado por cada participante no processo regulamentar.
} 
Como se trata de um processo que objetiva a edição de uma regulamentação que não pode ficar pendente de conclusão por um prazo indeterminado, o princípio da ampla defesa aplica-se de forma limitada. Os princípios da duração razoável do processo e da eficiência da Administração Pública (artigos $5^{\circ}$, LXXVIII e 37 caput da Constituição Federal) impedem a aplicação plena do princípio da ampla defesa no processo regulamentar (artigo $5^{\circ}, \mathrm{LV}$ ), até porque esse princípio será respeitado com todo seu rigor no processo administrativo diante de ato administrativo ulterior e no processo judicial.

Desse modo, o princípio da ampla defesa é observado mediante a participação do contribuinte no processo, com a possibilidade de este comentar a regulamentação fiscal e apresentar estudos técnicos ou outras provas que suportem os seus comentários. Contudo, o contribuinte não tem direito a apresentação de recursos diante da edição da regulamentação fiscal final, para que esta seja reformada. Exatamente por isso Francesco Manganaro afirma que a possibilidade de participação e colaboração não exclui o exercício de poderes unilaterais pela Administração Pública (com a rejeição dos comentários apresentados, por exemplo), os quais, quando utilizados, devem ser devidamente motivados, em atenção ao princípio da motivação, abordado a seguir. ${ }^{295}$

\section{IV.C.2 Princípio da Motivação}

O princípio da motivação dos atos administrativos tem fundamento no próprio Estado de Direito e na legalidade. ${ }^{296}$ Apenas com a justificação do ato administrativo é que se permite a verificação da sua conformidade com o ordenamento jurídico, com o respeito à segurança jurídica e à liberdade. A motivação evita o arbítrio e assegura a aplicação isonômica da lei. Esse princípio é tranquilamente aceito em nosso ordenamento jurídico na atualidade e está assegurado de forma explícita, no âmbito da Administração Pública Federal, por exemplo, no inciso VII do parágrafo único do artigo $2^{\circ}$ e no artigo 50 da Lei n. 9.784/99.

Não obstante, não se pode olvidar que a tranquila aceitação atual do princípio da motivação decorre de um processo evolutivo, representativo do progresso do Estado de

\footnotetext{
${ }^{295}$ MANGANARO, Francesco. Principio di Buona Fede..., p. 146.

${ }^{296}$ MELLO, Celso Antônio. Curso de Direito Administrativo..., p. 102 e seguintes.
} 
Direito, sendo que, no passado, reinava a ideia da não obrigatoriedade de justificação dos atos administrativos. ${ }^{297}$

Com a maior importância conferida à atribuição regulamentar da Administração Tributária, deve ser reconhecida como obrigatória a justificação da regulamentação tributária. ${ }^{298}$ Em outras palavras, a concentração de poder na Administração Tributária deve vir acompanhada de ônus adicional constituído na obrigação de motivação da regulamentação fiscal. Não é suficiente conhecer o resultado (i.e., a regulamentação fiscal), sendo necessário entender o porquê desse resultado, especialmente quando há um reenvio da lei à regulamentação ou quando estão presentes questões técnicas, como, por exemplo, a apuração da margem de valor agregado no ICMS-ST ou a qualificação de riscos para fins do SAT.

Admitir que a regulamentação tributária pudesse ter um papel tão relevante, sem qualquer obrigação de justificação no processo regulamentar, seria um convite ao arbítrio, que pode ser realizado de forma sutil e perigosa nesse campo. Do mesmo modo, aceitar que o regulamento possa dispor livremente sobre um dado tema pelo fato de a lei ter previamente estabelecido que norma infralegal regulamentará o assunto, sem qualquer motivação, constituiria uma oportunidade para o abuso e para a criação de desigualdades. Daí, sim, haveria uma violação ao Estado de Direito.

Por tais razões, deve ser reconhecida uma amplitude maior do princípio da motivação, alcançando não só os atos administrativos individuais como também a regulamentação fiscal, como forma de assegurar a certeza jurídica e a liberdade. ${ }^{299}$

\footnotetext{
${ }^{297}$ Odete Medauar relata que tradicionalmente prevalecia a ideia de não obrigatoridade de motivação dos atos administrativos, sobretudo nos ordenamentos jurídicos sob influência francesa, o que foi superado ao longo do tempo pelo reconhecimento da necessidade de motivação do ato administrativo, obrigação essa reconhecida em lei na França (1979) e em outros países. (MEDAUAR, Odete. O Direito Administrativo em Evolução..., p. 197 e seguintes).

${ }^{298}$ Semelhante raciocínio foi feito por Carlos Ari Sundfeld para justificar a necessidade de motivação dos atos administrativos, sob a luz da presunção de legitimidade desses (SUNDFELD, Carlos Ari. Motivação do Ato Administrativo como Garantia dos Administrados. Revista de Direito Público, São Paulo, Editora Revista dos Tribunais, v. 75, p. 120, 1985).

299 Joaquín Álvarez Martínez justifica a motivação dos atos tributários nos seguintes princípios constitucionais na Espanha: o princípio da interdição da arbitrariedade; o princípio da segurança jurídica; o princípio da igualdade; o princípio da tutela judicial efetiva; o princípio de objetividade da administração no serviço dos interesses gerais; e o princípio da submissão da administração aos fins que a justificam, à lei.
} 
A fundamentação do princípio da motivação dos atos administrativos com base no Estado de Direito, dada por Alberto Ramon Real, é plenamente aplicável à exigência de motivação dos regulamentos fiscais:

El derecho del administrado - que ha dejado de ser el súbdito del príncipe para volverse, como ciudadano, partícipe de la formación de la voluntad del estado, -- requiere la justificación legal de la competencia y de su ejercicio racional. El gobierno por persuasión y consentimento tiende a sustituir, em lo posible, a la dominación coactiva. ${ }^{300,301}$

Frise-se que a adoção do princípio da motivação na edição da regulamentação fiscal permite a aplicação da teoria dos motivos determinantes aos regulamentos, ${ }^{302}$ segundo a qual o ato administrativo motivado fica vinculado à justificação respectiva. Nesse passo, se a justificação é falsa, equivocada ou ilegal, a norma infralegal editada pela Administração Tributária com base em tais motivos não é válida. Não poderá haver uma nova motivação da regulamentação fiscal, em quebra de confiança na relação com o contribuinte.

Alguns exemplos ajudam a demonstrar a importância desse princípio: imagine-se a reclassificação do risco de uma dada atividade econômica de leve para grave para fins do SAT em razão de um erro do Poder Executivo. Como pode o contribuinte questionar o erro diante da ausência de qualquer explicação do fisco? Como pode o Poder Judiciário corrigir o erro se não sabe as razões para o Executivo ter alterado o seu posicionamento? Deve ser aceito o erro cometido em razão de o Executivo poder aferir o risco das atividades econômicas para fins de SAT, com o complemento da regra-matriz tributária dessa contribuição no regulamento, como decidido pelo Supremo Tribunal Federal?

O caso do ICMS-ST dos aparelhos celulares comentado no Capítulo II, em que o físco paulista não motiva a adoção de uma margem de valor agregado $(38,58 \%)$ nem a

(MARTÍNEZ, Joaquín Álvarez. La Motivación de los Actos Tributarios. Barcelona: Marcial Pons, 1999. p. 38 e seguintes).

300 REAL, Alberto Ramon. Fundamentacion del Acto Administrativo. Revista de Direito Público, São Paulo, Editora Revista dos Tribunais, v. 62, p. 13, 1982.

${ }^{301}$ Tradução livre: "O direito do administrado - que deixou de ser o súdito do príncipe para se tornar, como cidadão, um participante da formação da vontade do estado, - requer a justificação legal da competência e do seu exercício de forma racional. O governo por persuasão e consentimento tende a substituir, no possível, a dominação coativa."

302 Sobre a teoria dos motivos determinantes, são preciosos os estudos de Hely Lopes Meirelles (MEIRELLES, Hely Lopes. Direito Administrativo Brasileiro. 31. ed. São Paulo: Malheiros, 2005. p. 197198). 
substituição da mesma na regulamentação desse tributo poucos meses depois $(21,54 \%)$, impede o contribuinte de questionar a legitimidade das tão diferentes margens eleitas.

Saliente-se ainda que, como o processo regulamentar é conduzido de forma prévia ao litígio, pode parecer que o princípio do contraditório não é uma questão relevante nesse processo. Entretanto, tal princípio é aplicável no processo regulamentar em virtude do princípio do devido processo legal, como explicado acima, o que é fundamental para permitir a efetiva discussão acerca da regulamentação fiscal a ser editada. Adicionalmente, deve-se ter em mente que apenas com a aplicação do princípio da motivação é que se poderá assegurar o contraditório em momento posterior.

Logo, o desrespeito ao princípio da motivação no processo regulamentar, com o não esclarecimento explícito das razões da regulamentação fiscal, ou dos motivos de acolhimento ou recusa de comentário do contribuinte, acarreta o automático desrespeito ao contraditório, pois o direito de o contribuinte questionar o porquê de a regulamentação ter sido ao final editada, de uma forma ou de outra, fica cerceado. Logo, a ausência de motivação ou ainda a motivação insuficiente viola o princípio da motivação e o do contraditório.

Note-se ainda que a delicada questão da suficiência da motivação deve ser resolvida sob a luz da possibilidade efetiva de o Poder Judiciário verificar a legalidade da regulamentação editada. Para que o Judiciário possa realizar tal análise e decidir de forma motivada (artigo 93, IX da Constituição Federal), é imprescindível que a regulamentação fiscal tenha sido devidamente fundamentada. Se alguma questão importante não tiver sido ventilada na justificação da regulamentação, daí o princípio da motivação terá sido violado.

Fora de dúvida, portanto, que o princípio da motivação da regulamentação fiscal objetiva não só o controle da legalidade da regulamentação, bem como a preservação do contraditório após a sua edição. É o contraditório que assegurará o pleno acesso ao Poder Judiciário nos casos de ameaça ou lesão de direito.

\section{IV.C.3 Princípio da Isonomia Tributária}


O artigo 150, II da Constituição Federal estabelece que é vedado instituir tratamento fiscal desigual entre contribuintes que se encontrem em situação equivalente. Em outras palavras, tal princípio exige que se deve tratar aqueles que se encontram em situação equivalente de forma igual, e os que não se encontrem em tal situação, de forma diferente. Isso significa que o princípio da isonomia pressupõe a diversidade de situações e exige a comparação entre as mesmas, para que o tributo seja instituído de tal forma a se alcançar um resultado igualitário e justo sob a luz da capacidade contributiva. ${ }^{303}$ A igualdade constitui um princípio vazio ligado às ideias de justiça, segurança jurídica e liberdade. $^{304}$ Conceito chave desse princípio é o critério de comparação ou fator de discriminação. ${ }^{305}$

Com a inflação legislativa e a complexidade da vida econômica atual, reclama-se a igualdade não só na instituição do tributo em lei como também na sua aplicação efetiva diante do contribuinte. Como adverte Klaus Tipke, somente se observa o princípio da igualdade aquele direito material que pode ser executado e é executado na prática com observação à igualdade. ${ }^{306}$ Por isso, Tipke afirma que:

leis tributárias que correspondem ao princípio da igualdade não são em si suficientes para a realização do princípio da igualdade; para tanto, é necessário que as leis tributárias também sejam executadas (aplicadas) de modo igual. ${ }^{37}$

De nada valeria o respeito à isonomia tributária na lei, se esta fosse aplicada de forma desigual.

Apesar de esse não ser o foco de seu estudo, Tipke reconhece como pressuposto para a aplicação isonômica das leis tributárias a interpretação igual dessas leis pela Administração Tributária, o que torna fundamental a regulamentação fiscal. ${ }^{308}$ Ou seja,

\footnotetext{
${ }^{303}$ Nos Estados Unidos e na Alemanha, o princípio da igualdade alcançou, em determinados momentos, horizontes mais amplos, abrangendo ideias como equal protection e minimal protection. (TORRES, Ricardo Lobo. A Legitimação da Capacidade Contributiva e dos Direitos Fundamentais do Contribuinte. In: SCHOUERI, Luís Eduardo (coord.) Direito Tributário - Volume I. Homenagem a Alcides Jorge Costa. São Paulo: Editora Quartier Latin, inverno de 2003. p. 430.)

${ }^{304}$ TORRES, Ricardo Lobo. Tratado de Direito Constitucional..., p. 153.

305 MELlO, Celso Antônio Bandeira. Conteúdo Jurídico do Princípio da Igualdade. 3. ed. São Paulo: Malheiros, 1997. p. 23 e seguintes.

306 TIPKE, Klaus. Moral Tributaria del Estado $Y$ de Los Contribuyentes (Besteuerungsmoral und Steuermoral). Tradução: Pedro M. Herrera Molina. Madri: Marcial Pons, 2002. p. 78.

307 TIPKE, Klaus. A Necessidade de Igualdade..., p. 363.

308 TIPKE, op. cit., p. 362.
} 
para que se respeite o princípio da igualdade na instituição e a cobrança de tributos, é preciso que seja editada também regulamentação tributária que proporcione a construção da mesma norma pelos diferentes intérpretes, ou pelo menos que tente criar condições para tanto, ficando os contribuintes em situação equivalente, sujeitos ao mesmo ônus fiscal. Apenas a busca da uniformidade na interpretação e da execução igualitária das leis tributárias permitirá a instauração de um ambiente seguro juridicamente, que proporcione a livre iniciativa e a livre concorrência, princípios esses previstos no artigo 170 da Constituição Federal.

Nesse contexto, tendo em vista as dificuldades inerentes à interpretação propriamente dita quando estão exclusivamente presentes juízos de legalidade, o princípio da igualdade exige que o contribuinte participe do processo regulamentar para que esse possa discutir junto ao fisco as diferentes normas que podem ser extraídas do texto escrito da lei, o que permite o reconhecimento, antes do litígio, da interpretação prevalente, que deve então ser aplicada de forma isonômica.

Além disso, nos casos de reenvio à regulamentação fiscal, ou quando o fisco preenche conceitos indeterminados utilizados em lei com dados da realidade, o princípio da isonomia tributária requer a participação do contribuinte para que este possa verificar que o dever regulamentar é exercido com respeito ao princípio da isonomia tributária, e não de maneira que acarrete uma situação de desigualdade, com a criação de um privilégio odioso (seja dentro de um grupo de contribuintes ou entre grupos diferentes). ${ }^{309}$

O caso dos aparelhos celulares e do ICMS-ST mencionado no Capítulo II pode novamente ser utilizado para elucidar a questão. Ao se lançar na atividade de fixação da margem de valor agregado dos aparelhos celulares para fins do ICMS-ST, o fisco poderia ter reconhecido a existência de dois mercados distintos dessas mercadorias, quais sejam: o mercado varejista propriamente dito e o mercado composto pelas empresas de telecomunicações. Apesar da questão relativa à própria existência de dois mercados

\footnotetext{
${ }^{309}$ Ives Gandra Martins defende que somente a lei pode criar círculos de contribuintes que escapam à estrita isonomia, ou seja, que recebem um tratamento diferenciado em razão de particularidades, com nítido caráter interventivo. (MARTINS, Ives Gandra. O Princípio da Legalidade no Direito Tributário Brasileiro..., p. 349). Tipke afirma a violação ao princípio da isonomia quando o círculo de beneficiados não é determinado em lei, mas a subvenção é concedida de forma arbitrária a apenas um grupo representado por um poderoso lobby. (TIPKE, Klaus. Princípio de Igualdade e Ideia de Sistema no Direito Tributário. Tradução: Brandão
} 
diferentes envolver questões jurídicas e econômicas, pode-se afirmar que, se for concluído que existem dois mercados para as mesmas mercadorias, o fisco teria a obrigação de identificar a margem de valor agregado em cada um desses mercados para fins do ICMSST, em observação ao princípio da isonomia tributária. Por outro lado, se o contrário for admitido como correto, daí o fisco deveria identificar apenas uma única margem de valor agregado na determinação do ICMS-ST dos aparelhos celulares.

Clara, portanto, a necessidade de instituição de um processo com a participação do contribuinte para que se possa verificar se a regulamentação tributária foi editada de forma legítima, com respeito à isonomia tributária.

\section{IV.C.4 Princípio Democrático}

O princípio democrático encontra-se positivado em alguns dispositivos da Constituição Federal comono artigo $1^{\circ}$, que estabelece que a República Federativa do Brasil constitui um Estado Democrático de Direito; no artigo 14, que trata do sufrágio universal; no parágrafo $2^{\circ}$ do artigo 61 , que trata da iniciativa popular das leis, entre outros. O preâmbulo da Constituição também deixa claro que a República Federativa do Brasil constitui um Estado Democrático.

Embora não haja um sentido único de democracia, pode-se utilizar o conceito de Bobbio de que a democracia reflete o exercício do poder público em público. ${ }^{310}$ Ao reconhecer o caráter dinâmico da democracia, ${ }^{311}$ Bobbio expressa seu entendimento no sentido de que a democracia é "um conjunto de regras de procedimento para a formação de decisões coletivas, em que está prevista e facilitada a participação mais ampla possível dos

Machado. In: MACHADO, Brandão (coord.) Direito Tributário: Estudos em Homenagem ao Prof. Ruy Barbosa Nogueira. São Paulo: Saraiva, 1984. p. 526-527).

${ }^{310}$ BOBBIO, Norberto. O futuro da democracia. São Paulo: Editora Paz e Terra, 2006. p. 98.

311 José Afonso da Silva explica o caráter dinâmico da democracia ao afirmar que a democracia é um processo evolutivo que nunca se realiza em sua inteireza, estando baseada em dois fundamentos, quais sejam: (i) a soberania popular; e (ii) a participação, direta ou indireta, do povo no poder. Novas técnicas ao longo do tempo vão criando novas formas de participação no poder. Afonso da Silva reconhece como correto o conceito de democracia de Lincoln no sentido de que essa é o governo do povo, pelo povo e para o povo. A limitação desse conceito está na conceituação de democracia como "governo", quando essa é muito mais do que isso, constituindo um modo de vida e, principalmente, processo. (SILVA, José Afonso. Curso de Direito Constitucional Positivo..., p. 128 e seguintes.) 
interessados". ${ }^{312}$ Quanto mais se aumentam as possibilidades de participação em diferentes situações, mais se atende ao princípio democrático. ${ }^{313}$

O princípio democrático, como apontado no início do presente trabalho, tem sua origem e evolução intimamente ligadas ao advento e desenvolvimento do Estado de Direito. A participação no processo de criação do ordenamento jurídico, com base no princípio democrático, condiciona o exercício do poder, que fica obrigado a considerar a posição dos participantes e, consequentemente, cria melhores condições para proteção da liberdade e da segurança jurídica. Nesse passo, a participação do contribuinte no processo regulamentar permite à Administração Tributária ter o conhecimento das diferentes "normas espelho" construídas pelos contribuintes sobre o mesmo assunto específico, permitindo que a regulamentação ao final editada seja o fruto maduro de uma discussão necessária.

Portanto, a participação do contribuinte na edição da regulamentação fiscal por meio de um processo específico constitui aplicação do princípio democrático, assegurando a sua interferência na produção de regulamentos. Ainda que seja apolítica e apenas técnica, a participação do contribuinte na edição da regulamentação tributária legitima e regula a influência desse no Executivo, cuja finalidade é a produção de uma regulamentação fiscal de melhor qualidade e a proteção de seus direitos, com a redução de litígios.

Considerando que o reconhecimento do direito à participação do contribuinte na edição da regulamentação tributária legitima esse direito, tornando público o modus operandi da Administração Tributária nesse campo, o atual exercício informal desse direito passa a ser transparente, e a influência ilícita na produção da regulamentação físcal passa a ser combatida de forma ostensiva. ${ }^{314}$

\footnotetext{
${ }^{312}$ BOBBIO, op. cit., p. 22.

313 “O princípio democrático outra cousa não é, do ponto de vista político, senão a ingerência dos governados na obra de governo ou a organização de um sufrágio que faça essa ingerência mediante canais representativos.” (BONAVIDES, Paulo. Teoria do Estado. p. 314)

314 A participação do contribuinte no processo regulamentar evita, assim, a regulamentação fiscal encomendada, como parece ter ocorrido no notório caso envolvendo grande rede de restaurantes "fast food" que aparentemente contratou escritório de consultoria tributária para influenciar o fisco a editar regulamentação tributária sobre tema que lhe interessava (Ato Declaratório Interpretativo n. 2/2002). Ou seja, o processo regulamentar evita que o fisco seja capturado por certos contribuintes, com a participação de terceiros influentes no fisco, e que a regulamentação tributária seja produto dessa influência. (RUBIRA, Juan José Lavilla. El Procedimento..., p. 342).
} 
Frise-se ainda que não deve ser atribuída voz ampla e irrestrita a qualquer contribuinte interessado em um determinado assunto, que deseje participar do processo de edição da regulamentação tributária. É necessário que exista uma relação de pertinência lógico-jurídica entre a matéria a ser regulamentada e a legitimidade do contribuinte para comentar a regulamentação proposta. Por exemplo, a regulamentação sobre a tributação de seguradoras deve ser comentada apenas por essas empresas, e não por pessoas físicas, empresas comerciais, indústrias, etc. É claro que, dependendo da matéria regulada, podem existir milhões de interessados que satisfaçam tal critério, caso no qual o fisco pode estabelecer condições adicionais para o reconhecimento de legitimidade, desde que essas sejam legítimas. ${ }^{315}$

\section{IV.C.5 Princípio da Boa-fé}

O princípio da boa-fé tem sua origem no instituto romano da fides, segundo o qual o conquistador, em virtude de sua posição de superioridade, deveria tratar com lealdade o conquistado, estabelecendo uma relação de confiança. ${ }^{316}$ Referido princípio, ao envolver os conceitos de "lealdade" e "confiança", constituía uma via de comunicação entre o Direito e a Moral, ${ }^{317}$ protegendo aquele que se situava em uma situação de debilidade diante de outro.

Esse princípio é tranquilamente aceito nas relações de direito privado (entre iguais e desiguais, como no caso do direito comercial e do direito do consumidor), mas também é aplicável e até mesmo mais necessário no direito público (entre desiguais), como demonstração da lealdade da Administração Pública, como vem sendo defendido por diversos autores. ${ }^{318,319,320}$

\footnotetext{
315 Nos Estados Unidos, alguns administrativistas afirmam que parecia não haver disputas envolvendo a exclusão de participantes no processo de rule making, o que é razoável sob a luz da ideia de que é interesse da própria agência reunir o maior número possível de interessados que possam comentar a regulamentação proposta. (STRAUSS, Peter. Gellhorn and Byse's Administrative Law..., p. 305).

${ }_{316}$ MANGANARO, Francesco. Principio di Buona Fede..., p. 121.

${ }^{317}$ PEREZ, Jesus Gonzalez. El Principio General de La Buena Fe en El Derecho Administrativo. Madri: Editorial Civitas, 1983. p. 17.

${ }^{318}$ MANGANARO, op. cit., p. 56.

319 ANTONIAZZI, Sandra. Tutela Del Legittimo Affidamento Del Privato nei Confronti della Pubblica Amministrazione. Torino: Giappichelli, 2005. p. 279-280.

${ }^{320}$ PEREZ, op. cit., p. 37.
} 
O princípio da boa-fé é vazio e busca proteger a justiça, a liberdade e a igualdade. O seu conteúdo essencial consiste em um dever de não causar danos a terceiros. Trata-se de uma questão moral e de solidariedade, que exige uma atitude correta e coerente do homem comum, ${ }^{321}$ uma atitude justa diante de uma situação concreta, capaz de criar uma relação de confiança no outro. ${ }^{322}$ Quando a lei não contém uma resposta ou um critério de decisão para uma determinada situação concreta, o princípio da boa-fé acaba por assumir papel relevante na construção da resposta ou da decisão.

$\mathrm{Na}$ Constituição Federal, pode-se afirmar que o princípio da boa-fé nas relações entre a Administração Pública e o particular encontra-se inserido no princípio da moralidade administrativa (artigo 37), ${ }^{323}$ bem como na dignidade da pessoa humana (artigo $1^{\mathrm{o}}$, III) e na solidariedade (artigo $\left.3^{\mathrm{o}}, \mathrm{I}\right) .^{324,325}$ A referência a uma sociedade fraterna no preâmbulo da Carta Magna também leva a concluir pela presença do princípio da boa-fé em sede constitucional.

No Direito Tributário pátrio, o princípio da boa-fé é aplicável nas relações entre a Administração Tributária e o contribuinte, sendo que ambos devem pautar a sua conduta sob a luz de tal princípio.

Em um ambiente em que a lei por si só não é mais suficiente para estabelecer o modo pelo qual a Administração Tributária deve se comportar, o princípio da boa-fé se torna ainda mais importante para pautar a conduta do fisco, exigindo-se do último a adoção de medidas que demonstrem o caráter leal e honesto de suas atitudes, como a instauração do processo com a participação do contribuinte na edição de regulamentos tributários.

Do mesmo modo que a boa-fé exige da Administração Tributária a motivação de suas decisões como forma de demonstrar uma atitude marcada pela legalidade, a boa-fé

\footnotetext{
${ }^{321}$ Registre-se que o princípio da boa-fé tem contato com o princípio da razoabilidade, contido na cláusula do devido processo legal.

${ }^{322}$ MANGANARO, Francesco. Principio di Buona Fede..., p. 117-119.

${ }^{323}$ Celso Antônio Bandeira de Mello reconhece a presença do princípio da boa-fé no princípio da moralidade administrativa. (MELLO, Celso Antônio Bandeira de. Curso de Direito Administrativo..., p. 109).

${ }^{324}$ Francesco Manganaro também assenta o princípio da boa-fé na solidariedade e na dignidade humana na Itália. (MANGANARO, op. cit., p. 115-116). Sandra Antoniazzi também reconhece a presença do princípio da boa-fé na constituição italiana em virtude da presença do dever de solidariedade.

325 Amelia González Méndez considera o princípio de boa-fé como um princípio geral de direito e relata como, na Espanha, esse princípio foi sendo reconhecido pela jurisprudência e pela legislação. (MÉNDEZ, Amelia González. Buena Fe Y Derecho Tributario. Madri: Marcial Pons, 2001. p. 42 e seguintes)
} 
também reclama a instauração do processo regulamentar, no qual se dá transparência a todas as etapas entre a edição da lei e a publicação da regulamentação fiscal final, com a abertura de todas as informações e estudos técnicos levados em consideração na elaboração da norma infralegal. ${ }^{326}$ Com a adoção de tal processo, o contribuinte terá a tranquilidade de que o fisco cobra o tributo de forma leal e em conformidade com o ordenamento jurídico, não cobrando mais do que lhe é devido.

\section{IV.C.6 Princípio da Transparência Tributária}

Segundo Fritz Neumark, o princípio da transparência tributária exige que as leis e a regulamentação tributária sejam estruturadas de maneira técnica e jurídica, o mais inteligível possível, buscando-se a clareza e a precisão, com a exclusão do máximo de dúvidas possível. ${ }^{327}$ Ricardo Lobo Torres o denomina de princípio da clareza. ${ }^{328}$

O princípio da transparência fiscal não está consignado explicitamente em um dispositivo constitucional, mas é fora de dúvida que ele está presente em todo o ordenamento jurídico nacional, sendo um princípio do Estado de Direito.

Diante da complexa realidade atual, para aplicar de forma efetiva o princípio da transparência fiscal, é preciso que se permita a participação do contribuinte no processo de feitura da regulamentação fiscal, para que ele possa colaborar na produção de uma regulamentação o mais clara possível.

Como explorado no Capítulo II, o contribuinte poderá, já no processo regulamentar, confrontar a "norma espelho" com a regulamentação fiscal a ser editada, o que ocorre na atualidade apenas diante do Poder Judiciário ou após a lavratura de um auto de infração.

\footnotetext{
${ }^{326}$ Amelia González Méndez reconhece que a motivação dos atos administrativos é uma questão muito conexa com o princípio da boa-fé e defende a aplicação desse princípio "a todo el tráfico jurídico". (MÉNDEZ, Amelia González. Buena Fe..., p. 163, 172-173)

${ }^{327}$ Fritz Neumark criticava a produção de leis fiscais de juristas para juristas, o que impedia a compreensão da lei fiscal pelos contribuintes em geral, mas essa não se mostra, na maioria das vezes, a realidade brasileira. (NEUMARK, Fritz. Principios de la Imposición. Madri: Instituto de Estudios Fiscales, 1974. p. 408).

${ }^{328}$ TORRES, Ricardo Lobo. Tratado de Direito Constitucional..., p. 262 e seguintes.
} 
Apenas com a participação do contribuinte no referido processo regulamentar, com o confronto da "norma espelho", é que se aumentam as possibilidades de a regulamentação ao final editada ser a mais clara possível.

\section{IV.C.7 Princípio da Eficiência}

O princípio da eficiência da Administração Pública encontra-se previsto no caput do artigo 37 da Constituição Federal. Trata-se de um princípio vazio, de ponderação de alternativas diante de uma situação determinada, sendo dever do agente público adotar aquela que se mostre mais eficiente, ou seja, aquela que atende da melhor forma o fator de eficiência relevante aplicável à situação.

Por exemplo, na construção de uma obra pública com exigências técnicas prédefinidas e imutáveis, o princípio da eficiência é atendido mediante a instalação de um processo licitatório que demande dos licitantes habilitados a construção da mesma obra com o menor custo possível. ${ }^{329}$

Em outras situações, o fator de eficiência pode ser a técnica utilizada, a combinação entre técnica e custo, a utilização específica de um determinado componente, etc.

Pensando na construção da regulamentação tributária, pode-se afirmar que o fator de eficiência é o nível de concordância entre o contribuinte e a Administração Tributária acerca do conteúdo da regulamentação fiscal sob a luz do ordenamento jurídico. Isso porque a regulamentação tributária somente é útil à medida que ambos, Administração Tributária e contribuinte, podem utilizá-la como ferramenta de interpretação. ${ }^{330}$ Assim, quanto maior o nível de concordância acerca da regulamentação fiscal e da conformidade dessa com o ordenamento jurídico, maior será o nível de eficiência do físco nessa atividade.

\footnotetext{
${ }^{329}$ Marcus Juruena Villela Souto afirma que o princípio da eficiência exige que o agente público tenha atenção a duas dimensões, quais sejam: (i) a dimensão do uso dos meios necessários de forma racional e otimizada; e (ii) a dimensão do nível de satisfação efetiva alcançado. (SOUTO, Marcus Juruena Villela. Audiência Pública e Regulação. Revista de Direito Público da Economia - RDPE, Belo Horizonte, Editora Fórum, v. 4, p. 161, 2003.).

330 "Regulations, whether of a legislative or an interpretive character, can serve a useful function only if both administrators and taxpayers can rely on them." (BANKMAN, Joseph; KLEIN, William A. Federal Income Taxation. 11. ed.Nova Iorque: Aspen Law \& Business, 1997. p. 67) Tradução livre: "Regulamentos, se de
} 
Trata-se de um fator de difícil medição, mas seria interessante que pesquisadores tentassem identificá-lo sob a luz dos litígios existentes na esfera administrativa e judicial, assim tal pesquisa permitiria reconhecer de forma precisa os temas que demandam mais atenção e diálogo.

Quanto ao processo regulamentar com a participação do contribuinte, como explicado acima, tal processo permite o acompanhamento e discussão de cada etapa na produção da regulamentação fiscal. Por mais esclarecido que o agente da Administração Tributária possa ser, o processo regulamentar permite a participação do contribuinte e o confronto prévio, antes da edição da regulamentação fiscal em sua versão final. No confronto, a Administração Tributária poderá testar a regulamentação elaborada unilateralmente diante da "norma espelho" construída pelo contribuinte, o que poderá evitar a inclusão de dispositivos na regulamentação final que violariam o ordenamento jurídico e acarretariam litígios.

Evidente, assim, que o processo regulamentar com a participação do contribuinte constitui uma forma de aplicação do princípio da eficiência, já que busca a concordância do contribuinte e do fisco acerca da regulamentação fiscal, evitando-se litígios. ${ }^{331}$

Além disso, a participação do contribuinte na edição da regulamentação tributária permitirá a contribuição não apenas de técnicos da Administração Tributária, mas também de representantes do contribuinte e de outros experts em tributação na elaboração de uma melhor regulamentação. A possibilidade dessa discussão poderá evitar a distorção ou atropelo de conceitos jurídicos importantes na regulamentação da lei, o que é fundamental diante da presença dos conceitos indeterminados na legislação tributária.

Poder-se-ia alegar que o processo regulamentar com a participação do contribuinte violaria o princípio da eficiência em virtude de o mesmo demandar tempo significativo até

caráter legislativo ou interpretativo, apenas conseguem ter uma função útil se ambos agentes públicos e contribuintes podem se basear nesses."

${ }^{331}$ Nos Estados Unidos da América, a participação do contribuinte na edição da regulamentação tributária é uma questão tranquila, havendo debate, inclusive, acerca da possibilidade de a primeira minuta da regulamentação ser elaborada por tributaristas do setor privado. (JOHNSTON, David Cay. I.R.S. Letting Tax Lawyers Write Rules. The New York Times. Nova Iorque: The New York Times Company, 9/3/2007. 
a sua conclusão, o que impediria a edição da regulamentação fiscal a tempo de permitir a orientação do contribuinte antes de a lei fiscal produzir efeitos ou logo após esse momento.

Entretanto, é possível contornar essa situação, com a adoção de alguma medida na linha daquela praticada nos Estados Unidos da América. De acordo com o artigo 7805(e) do Internal Revenue Code, o fisco norte-americano pode editar regulamentação físcal temporária que deve produzir efeitos até que a regulamentação final seja publicada. A regulamentação fiscal temporária vige e produz efeitos por três anos, sendo que, antes do vencimento desse prazo, a regulamentação definitiva deve ser editada. Um mecanismo dessa natureza permite a harmonização da questão da eficiência com os demais fundamentos que justificam o processo regulamentar com a participação do contribuinte.

\section{IV.D Benefícios da Participação do Contribuinte na Edição da Regulamentação Tributária}

A participação do contribuinte no processo de edição da regulamentação tributária dará oportunidade a ele para, antes do litígio e sem prejuízo da revisão do Poder Judiciário, discutir o conteúdo das normas infralegais propostas, podendo refinar o seu conteúdo, com a sua melhora qualitativa, podendo também afastar normas que acarretariam a violação de direitos fundamentais. Em um ambiente de cooperação mútua, as questões levantadas pelo contribuinte deverão ser devidamente analisadas e contempladas pela Administração Tributária, que as responderá na motivação da regulamentação fiscal ao final editada.

Esse processo de notice-and-comment tende a melhorar a relação entre fisco e contribuinte porque exige um compromisso mútuo a fim de construir um ambiente claro e seguro juridicamente. Nessa arena, contribuinte e fisco deverão abrir argumentos e informações de forma recíproca, com o escopo de produzir a regulamentação fiscal em conformidade com o ordenamento jurídico. Com a motivação da regulamentação tributária final, aceitando ou rejeitando os argumentos apresentados pelo contribuinte, deverá haver um desestímulo para discussão das normas infralegais no Poder Judiciário. Note-se que tal desestímulo variará dependendo da qualidade da fundamentação da regulamentação fiscal adotada na conclusão do processo regulamentar.

Disponível em: http://www.nytimes.com/2007/03/09/business/09tax.html?_r=2\&th=\&emc=th\&pagewan... Acesso em: 11 de janeiro de 2010). 
A produção de uma regulamentação tributária de melhor qualidade, fruto do processo regulamentar com a participação do contribuinte, proporcionará ainda a possibilidade de aplicação isonômica da lei tributária, promovendo, assim, a livre iniciativa e a livre concorrência de uma forma mais eficaz. Com efeito, uma regulamentação discutida com o contribuinte poderá permitir que todos os contribuintes de um mesmo mercado tenham a mesma interpretação da norma tributária, de tal modo que todos estejam sujeitos ao mesmo ônus fiscal. Assim, serão eliminadas ou reduzidas as eventuais vantagens competitivas decorrentes de diferentes interpretações da legislação tributária.

A participação do contribuinte permitirá também a sua colaboração com questões de simplificação tributária, propondo controles mais simples e menos custosos, afetando, consequentemente, os deveres instrumentais.

Como já salientado acima, o processo regulamentar permite que se acompanhem todas as etapas da produção da regulamentação fiscal, desde a sua proposta inicial até a sua redação final, inclusive com a análise de estudos técnicos eventualmente utilizados para sua produção. A organização de autos (físicos ou digitais) permitirá a documentação desse processo regulamentar, o que possibilitará a plena revisão judicial do modus operandi da Administração Pública e o seu comportamento e o do contribuinte nessa atividade. Logo, o Poder Judiciário estará melhor aparelhado para avaliar a regulamentação editada.

Portanto, pode-se afirmar que a utilização do processo regulamentar de forma adequada, mediante a cooperação mútua e sincera entre fisco e contribuinte, poderá viabilizar a produção de normas infralegais de melhor qualidade, proporcionando maior segurança jurídica, aplicação isonômica da lei de forma efetiva, evitando-se, assim, a distorção ou atropelo de conceitos jurídicos e a edição de regulamentação tributária arbitrária. A existência de uma motivação da regulamentação fiscal dará maior transparência da posição da Administração Tributária acerca do conteúdo da lei e, dependendo dos fundamentos utilizados, maior legitimidade e maior aceitação das normas infralegais editadas, o que evitará litígios dependendo dos motivos adotados. Tudo isso permitirá a plena revisão judicial da regulamentação fiscal editada. 


\section{IV.E Inexistência de Disponibilidade de Interesse Público}

O princípio da indisponibilidade dos interesses públicos pela Administração Pública impede os integrantes dessa última de disporem livremente de tais interesses, já que os mesmos são inapropriáveis. Tratando-se de interesses da coletividade, os membros da Administração Pública devem zelar por tais interesses, não podendo negociá-los de forma livre. ${ }^{332}$ É a lei que determina o regime jurídico dos interesses públicos, podendo-se extrair do princípio da legalidade a indisponibilidade dos referidos interesses. ${ }^{333}$ Por isso é que o princípio da legalidade consta expressamente do artigo 37 da Constituição Federal, estando o princípio da indisponibilidade dos interesses públicos nele implicitamente contido.

O tributo constituído em um caso concreto de acordo com o ordenamento jurídico é um interesse público, de tal maneira que a sua perseguição, desde o nascimento da relação jurídico-tributária até a sua extinção, não pode ser abandonada ao livre arbítrio da Administração Tributária, mas deve ser observada nos termos da lei.

Ciente de que os conceitos de "tributo", de "interesse público" e de “indisponibilidade" não constituem conceitos lógicos, mas sim de direito positivo, como explicam Odete Medauar ${ }^{334}$ e Heleno Torres, ${ }^{335}$ é importante mencionar que o processo de produção da regulamentação tributária com a participação do contribuinte não implica, em razão da natureza inerente desse processo, qualquer ato de disposição do interesse público. Com efeito, o processo regulamentar busca a identificação do conteúdo da norma fiscal em conformidade com o ordenamento jurídico, de tal modo a proporcionar segurança jurídica para a Administração Tributária e para o contribuinte. Essa atividade não abrange atos de disposição, de negociação de interesses, mas envolve, isso sim, o debate explícito, devidamente justificado em juízos de legalidade e, quando cabível, em juízos técnicos. Trata-se de atividade que antecede à constituição legítima do tributo e, portanto, do

\footnotetext{
${ }^{332}$ MELLO, Celso Antônio Bandeira de. Curso de Direito Administrativo..., p. 64-65.

${ }^{333}$ SILVEIRA, Paulo Fernando. Devido Processo Legal..., p. 76.

${ }^{334}$ MEDAUAR, Odete. O Direito Administrativo em Evolução..., p. 186-189.

335 TORRES, Heleno. Princípios de Segurança Jurídica e Transação em Matéria Tributária. Os Limites da Revisão Administrativa dos Acordos Tributários. In: SARAIVA FILHO, Oswaldo Othon de Pontes; GUIMARÃES, Vasco Branco (orgs.). Transação e Arbitragem no Âmbito Tributário: homenagem ao jurista Carlos Mário da Silva Velloso. Belo Horizonte: Fórum, 2008. p. 300-301.
} 
interesse público, não havendo que se falar em indisponibilidade de algo que ainda não foi constituído (ou seja, de uma potencialidade).

Como frisado anteriormente, o processo regulamentar não constitui uma arena para disputa de interesses de grupos de contribuintes, mas sim um ambiente de discussão técnica, focada na melhoria da regulamentação fiscal. No processo regulamentar, não se busca o "de acordo" do contribuinte à tributação, mas sim os seus comentários que possam melhorar a regulamentação fiscal, de tal sorte que a regulamentação fique em conformidade com o ordenamento jurídico e abranja não só os casos simples que ocorrem na realidade, mas também os complexos. Nesse passo, quando a Administração Tributária conduzir uma atividade tipificante limitada, com a coleta de dados da realidade, ela deverá cumprir a sua tarefa de forma imparcial e impessoal, evitando-se ser capturada por interesses parciais de grupos de contribuintes. A motivação da regulamentação fiscal será a demonstração da fidelidade da conduta da Administração Tributária diante da lei, e de que não houve qualquer negociação na busca do reconhecimento do interesse público.

Portanto, fica claro que o processo regulamentar não viola o princípio da indisponibilidade dos interesses públicos.

\section{IV.F Não Caracterização de Crime de Tráfico de Influência}

Para caracterização do crime de tráfico de influência previsto no artigo 332 do Código Penal, é necessário que o agente alardeie prestígio e poder a ponto de influenciar funcionário público, com a finalidade de obter vantagem para si ou para outrem. É irrelevante se o fim objetivado por meio da influência é lícito ou ilícito. ${ }^{336}$ É o caso, assim, daquele intermediário que oferece influência na Administração Tributária, mediante uma contraprestação, para que se produza a regulamentação fiscal de um dado modo. ${ }^{337}$ Não importa se a regulamentação está ou não de acordo com o ordenamento jurídico.

A participação do contribuinte no processo regulamentar não lhe atribui influência sobre agentes da Administração Tributária, passível de enquadramento no crime de tráfico

\footnotetext{
${ }^{336}$ MIRABETE, Julio Fabrini. Código Penal Interpretado. São Paulo: Atlas, 1999. p. 1805-1808.

337 Como parece ter ocorrido no notório caso de uma grande rede de restaurantes fast food que, aparentemente contratou escritório de consultoria tributária para influenciar a Receita Federal do Brasil a editar uma norma infralegal.
} 
de influência. Isso porque, ao se reconhecer a referida participação como um direito do contribuinte, a possibilidade de influenciar a edição da regulamentação tributária passa a ser regulada e acessível a todos os interessados, deixando de ser um diferencial odioso que pode ser oferecido apenas por um grupo de "privilegiados". O contribuinte passa a ter canal direto de comunicação com a Administração Tributária, não sendo necessários intermediários que tenham um acesso diferenciado ou exclusivo aos agentes da fazenda.

Além disso, a submissão da produção da regulamentação fiscal a um processo torna transparente o modus operandi da Administração Tributária, exigindo que essa aja nos estritos termos do ordenamento jurídico, sem dar mais atenção ou valor aos comentários de um determinado grupo de "privilegiados", em detrimento do contribuinte comum. O processo busca, assim, criar uma arena de iguais, onde todos os comentários apresentados devem ser ouvidos, analisados e decididos com base no ordenamento jurídico. Não há, consequentemente, tráfico de influência.

Muito pelo contrário. Para que se consiga combater de forma efetiva o crime de tráfico de influência, é necessário que se reconheça o direito do contribuinte de participar no processo de edição da regulamentação tributária, bem como que se atribua ao contribuinte o direito de provocar a edição da referida regulamentação. Apenas dessa forma se criarão condições para se reduzir o eventual prestígio de um grupo de "privilegiados" junto ao fisco que possa ser considerado como um diferencial merecedor de uma contraprestação.

Também por esse motivo o processo de edição da regulamentação fiscal se mostra interessante e merecedor de reconhecimento jurídico.

\section{IV.G Paradigmas}

Já há uma pequena interação na produção da regulamentação físcal entre a Administração Tributária e o contribuinte no campo da fixação do risco de atividades econômicas para fins de SAT e na determinação do fator acidentário previdenciário (“FAP”), estabelecido no artigo 10 da Lei n. 10.666/2003, mas tal interação não pode ser considerada como o direito de participação aqui discutido, dentro de um processo administrativo. O mesmo vale para a fixação da margem de valor agregado no campo do 
ICMS-ST. Isso porque os princípios explicados acima não são plenamente aplicados na edição da regulamentação tributária dessas matérias.

Com efeito, nesses casos, a Administração Tributária apenas colhe dados concretos do contribuinte, mas não explica nem justifica de forma clara o porquê de, por exemplo, uma atividade econômica ter tido o seu risco classificado como grave ou a razão da fixação da margem de valor agregado de uma dada mercadoria em um dado percentual. Também não se organizam autos para que possa ser realizada uma revisão da atividade regulamentar. Assim, não se pode falar que a pequena presença passiva do contribuinte nos casos acima possa caracterizar o direito de participação no processo regulamentar aqui discutido.

Outro exemplo nesse mesmo sentido é a obrigação de o fisco paulista, na definição dos produtos sujeitos ao regime do ICMS-ST, consultar previamente a (...) Federação das Indústrias do Estado de São Paulo-FIESP, a Federação do Comércio do Estado de São Paulo-FECOMÉRCIO, à Associação Comercial de São Paulo-ACSP, à Associação Paulista de Supermercados-APAS e a outras entidades representativas dos setores econômicos afetados, a critério da Secretaria da Fazenda (...), como estabelecido no parágrafo 16 do artigo $8^{\circ}$ da Lei n. 6.374/89, com a redação dada pela Lei n. 13.291/2008. Apesar de a consulta prévia às referidas entidades ser uma conquista por si só, não se pode ainda falar em processo regulamentar com a participação do contribuinte, como aqui estudado.

Sem dúvida, a participação de outras entidades representativas dos setores econômicos afetados pela inclusão de uma mercadoria no regime do ICMS-ST não pode ser deixada a critério do fisco, mas deve ser, isso sim, obrigatória. Como os membros das referidas entidades vão ficar submetidos à sistemática do ICMS-ST, referidas entidades devem ter reconhecido o direito de participar, permitindo que os seus membros exponham as razões pela necessidade ou não da instituição do ICMS-ST com relação a um certo produto. Não se deve limitar tal direito à FIESP, FECOMÉRCIO, ACSP e à ADAS.

Deve-se lembrar que a mecânica do ICMS-ST, dependendo de como implementada, pode ser prejudicial à concorrência, devendo, assim, ser reconhecido o direito incondicional de participação das entidades representativas dos setores afetados pela sua 
inclusão no ICMS-ST, sob risco de violação aos princípios da livre iniciativa e da livre concorrência. Além disso, deve-se exigir que a Administração Tributária justifique publicamente a razão de inclusão de um dado produto no regime do ICMS-ST. A constituição de autos combinada com a referida motivação permitirá o controle judicial dessa atividade. Desse modo, a obrigação de consulta introduzida pela Lei n. 13.291/2008 ainda não constitui o direito de participação do contribuinte no processo regulamentar aqui explorado.

Mais próximo do processo regulamentar sob estudo, mas ainda sem alcançar plenamente o direito de participação do contribuinte, é a consulta pública sobre minutas de normas e de procedimentos aduaneiros com vistas ao seu aperfeiçoamento, prevista na Portaria RFB n. 689/2008. Nesse processo de consulta, "a minuta do ato normativo será acompanhada da exposição de motivos, com indicação dos objetivos institucionais que se pretende alcançar com a nova regulamentação", conforme o parágrafo $2^{\circ}$ do artigo $1^{\circ}$ da referida portaria.

$\mathrm{O}$ artigo $2^{\mathrm{o}}$ da mesma norma estabelece a possibilidade de o contribuinte comentar a regulamentação, com a apresentação de críticas e sugestões, por período de tempo variável dependendo da complexidade e da extensão da matéria disciplinada, não inferior a dez dias. Tal processo possibilita e exige que o contribuinte apresente redação para a regulamentação aduaneira, bem como a justificação para a mesma, com a demonstração da sua pertinência, viabilidade e o atendimento dos objetivos institucionais perseguidos pela Receita Federal do Brasil. A referida portaria estabelece que os comentários apresentados pelo contribuinte serão levados em consideração na definição da versão final da regulamentação aduaneira e ficarão arquivados em banco de dados próprio para esse fim, pelo prazo de dois anos, contado da divulgação da consulta pública. A mesma portaria também dispõe que os comentários e sugestões apresentados pelo contribuinte não serão respondidos pela Receita Federal do Brasil.

A Portaria RFB n. 689/2008 é uma boa novidade que reconhece a importância da consulta do contribuinte no processo de edição da regulamentação fiscal, especificamente na seara aduaneira. Também é positivo o reconhecimento expresso da obrigação de a minuta da regulamentação fiscal ser acompanhada de exposição de motivos. No entanto, 
muitos ajustes devem ser feitos para que tal consulta pública possa ser reconhecida como o processo regulamentar com a participação do contribuinte aqui contemplado.

Primeiramente, a exposição de motivos do ato normativo infralegal a ser editado com base na referida portaria deveria contemplar não só os objetivos institucionais a serem alcançados pelo referido ato normativo mas também a sua conformidade com o ordenamento jurídico e as informações técnicas ou dados concretos relevantes para o caso. Apenas uma exposição de motivos que tenha essa abrangência asseguraria a participação efetiva do contribuinte, com uma visão mais completa do tema a ser regulamentado.

Em segundo lugar, é importante que os referidos objetivos institucionais a serem alcançados pela regulamentação sob discussão sejam determinados com base em critérios jurídicos, e não em critérios de outra ordem. Sem dúvida, a mera indicação de objetivos institucionais é muito vaga, dando espaço para que um comentário do contribuinte pertinente sob o ângulo jurídico seja desprezado em virtude de uma posição subjetiva do agente público sobre o objetivo institucional da norma infralegal.

Ademais, a exigência de a proposta inclusa no comentário do contribuinte vir acompanhada de demonstração da sua viabilidade pode barrar a análise de comentários relevantes sob a ótica jurídica. Já é complicado para o contribuinte compreender a ordem jurídica em sua inteireza; esperar que o contribuine possa conhecer as forças e mecanismos da Administração Tributária para aplicar uma ideia boa e adequada da perspectiva jurídica é um exagero. Por outro lado, tendo em vista as informações de que dispõe, o fisco pode reconhecer a pertinência jurídica da proposta do contribuinte e justificar de forma explícia a razão pela qual tal proposta é ou não viável.

O esclarecimento de que os comentários apresentados pelo contribuinte não serão respondidos individualmente pela Receita Federal do Brasil faz sentido, já que o importante é que eles sejam levados em consideração na elaboração da regulamentação fiscal, e não que eles sejam debatidos individualmente com o contribuinte que os apresentou. No entanto, faltou na Portaria RFB n. 689/2008 estabelecer a obrigação de a Administração Tributária motivar a versão final da regulamentação aduaneira. Nessa motivação, o fisco apresentaria os motivos e as razões para aceitação e/ou rejeição dos comentários apresentados pelos contribuintes. O fisco deve ser cauteloso nessa motivação, 
pois não poderá ignorar ou menosprezar comentários jurídicos relevantes, já que que estes poderão eventualmente ser utilizados para questionar a regulamentação editada perante o Poder Judiciário em momento posterior.

Finalmente, a regra da mencionada portaria de que os comentários dos contribuintes "permanecerão arquivadas, em banco de dados próprio para esse fim, pelo prazo de dois anos, contado da divulgação para consulta pública da minuta de norma a que se refira" não é interessante para defesa da legitimidade da norma ao fim editada. Isso porque a análise combinada entre a regulamentação ao final editada com os comentários apresentados certamente constituirá uma ferramenta necessária e muito útil para a interpretação da regulamentação e para o seu eventual controle judicial. O mais adequado seria manter arquivados e acessíveis os referidos comentários de forma permanente, permitindo-se que todos que tenham interesse na norma infralegal editada possam examiná-las em conjunto com os comentários apresentados. Pela mesma razão, é importante que o referido banco de dados seja público e acessível facilmente.

Como se percebe do acima exposto, os primeiros passos para a participação do contribuinte no processo de edição da regulamentação fiscal já foram dados. O importante agora é o aprofundamento e a continuação do estudo das bases jurídicas desse processo e do direito de participação, com vistas ao aprimoramento da regulamentação fiscal, maior segurança jurídica e redução de litígios. 


\section{CONCLUSÃO}

Muito embora o ideal exija que a lei trabalhe exclusivamente com conceitos determinados em atenção ao princípio da legalidade tributária, verificou-se, no curso do presente trabalho, que a utilização de conceitos indeterminados na lei ordinária é uma realidade que não pode ser ignorada ou ter a sua importância minimizada. Em alguns casos, a utilização de conceitos indeterminados na lei demanda esclarecimentos da interpretação desses pela Administração Tributária enquanto, em outros, pode ser necessária a complementação de tais conceitos na regulamentação tributária, com a coleta de dados da realidade. Nos casos em que a Administração Tributária apenas externa a sua interpretação de conceitos indeterminados utilizados na lei, estão normalmente envolvidos apenas juízos de legalidade. Já nas situações em que o fisco não só expõe a sua interpretação, mas também preenche conceitos indeterminados com dados da realidade, daí estão presentes não só de juízos de legalidade como também questões técnicas e concretas.

Neste último caso, a adoção de conceitos indeterminados acaba por impedir o estabelecimento de um conteúdo tal na lei ordinária que permita ao intérprete extrair dela um critério de decisão, para verificar se um dado evento será tributado ou não e com qual intensidade. Em tal situação, a Administração Tributária completa os conceitos indeterminados utilizados na lei por meio da regulamentação fiscal produzida com base em atividade tipificante limitada, que envolve a coleta de dados concretos da realidade. Para identificar a regra-matriz de incidência tributária em tais situações, o intérprete fica então obrigado a se debruçar não só sobre a lei ordinária, mas também sobre a regulamentação fiscal.

Além disso, existem situações em que a lei faz reenvios à regulamentação tributária, que acaba ficando responsável por dispor acerca de matéria sensível ao contribuinte, capaz de aumentar ou reduzir a carga tributária desse. Também existem casos em que a regulamentação estabelece deveres instrumentais para o contribuinte.

O contexto acima resumido representa uma flexibilização do princípio da legalidade tributária e demonstra a maior importância da regulamentação tributária na atualidade, apesar de esta última não ganhar o status de lei ordinária, o que seria uma 
deformação insuperável do Estado de Direito. Os casos dos semi-elaborados no ICMS, da margem de valor agregado no ICMS-ST e do SAT, todos julgados pelo Supremo Tribunal Federal, comprovam uma tendência nesse sentido.

Apesar dessa flexibilização, não se pode afirmar que a força da segurança jurídica, como forma de proteção da liberdade, tenha sido diminuída no ordenamento jurídico brasileiro, mas apenas e tão somente que a lei ordinária deixou de ser o veículo exclusivo para a concretização desse princípio/valor.

Com a sua jurisprudência, o Supremo Tribunal Federal assumiu uma responsabilidade prospectiva com relação à produção futura da regulamentação fiscal pela Administração Tributária, que deverá proporcionar segurança jurídica, com o respeito aos direitos fundamentais do contribuinte e às limitações constitucionais ao poder de tributar, assegurados pela Constituição Federal. A corte constitucional sinaliza que a segurança jurídica, materializada na legalidade tributária, é um mecanismo de garantia e não um fim em si próprio.

Essa flexibilização da legalidade tributária também exige que o Poder Legislativo passe a supervisionar de modo cauteloso e efetivo o exercício do poder regulamentar pelo fisco, podendo sustar os atos normativos por este expedidos, a fim de manter um ambiente de segurança jurídica, como faculta o artigo 49, V da Constituição Federal no âmbito federal.

É evidente que o reconhecimento da possibilidade de a Administração Tributária completar a lei ordinária via regulamentação fiscal representa uma alta concentração de poder, com risco sério à segurança jurídica e à liberdade. Esse risco se agrava à medida que o Judiciário pode entender não ser de sua alçada a revisão da regulamentação tributária editada, tendo em vista a presença de regulamentação editada com base em reenvio expresso em lei ou de regulamentação apta a complementar a lei ordinária, conforme a jurisprudência do Supremo Tribunal Federal.

Os exemplos estudados no Capítulo II demonstram que a Administração Tributária continua a não exercer o poder regulamentar em conformidade com o ordenamento jurídico, comprovando que o risco indicado no parágrafo anterior é real, estando os direitos 
fundamentais do contribuinte em posição fragilizada. O caso da definição do valor venal de imóveis para fins do IPTU, julgado pelo Supremo Tribunal Federal no passado, demonstra também que o poder regulamentar pode ser exercido de forma altamente abusiva.

Como os controles realizados pelo Poder Legislativo e pelo Judiciário são repreensivos, posteriores à edição da regulamentação fiscal, nada pode o contribuinte fazer para evitar que a Administração Tributária edite regulamentação fiscal opressora, o que cria um ambiente de insegurança e de preocupação.

Nesse cenário, deve-se reconhecer que a flexibilização da legalidade tributária deve ser equilibrada com o reconhecimento e fortalecimento da chamada legalidade processual, que requer que todos os atos da Administração Tributária, sejam eles normativos ou individuais e concretos, sejam precedidos por um processo administrativo com a participação do contribuinte. O processo permite a verificação do modus operandi da Administração Tributária e, portanto, a confirmação de que essa atuou conforme a legislação e o ordenamento jurídico como um todo, proporcionando um ambiente de certeza jurídica. Com o processo regulamentar, o Poder Judiciário passa a poder rever de forma plena como a atribuição regulamentar é exercida pela Administração Tributária.

A experiência norte-americana no processo de rule making no APA, com o noticeand-comment, demonstra que o processo para edição da regulamentação em geral é o contrapeso necessário para equilibrar os grandes poderes conferidos às agências daquele país, entre as quais se inclui o fisco norte-americano.

Tendo em vista que a atividade regulamentar que envolve a coleta de dados concretos não é puramente normativa, apresentando também traços adjudicatórios, o direito ao processo com a participação do contribuinte também tem fundamento no princípio do devido processo legal, posto que a regulamentação fiscal ao final produzida pode ter como efeito a indevida privação de bens do contribuinte por meio do tributo. Além disso, essa peculiaridade híbrida exige que a Administração Tributária fundamente a regulamentação fiscal editada conforme o princípio da motivação, sob pena de se impedir o controle de legalidade posterior pelo Poder Judiciário, com a plena compreensão das razões pelas quais a regulamentação foi editada de um modo ou de outro. 
Com essa maior interferência do fisco na legislação tributária, o princípio da isonomia reclama o processo administrativo com a participação do contribuinte para que a regulamentação fiscal seja editada com respeito à igualdade fiscal, sem criar indevidamente círculos de contribuintes privilegiados ou submetidos a regime fiscal mais oneroso, quando os mesmos se encontrem em situação equivalente.

Ademais, o processo regulamentar com a participação do contribuinte reflete a aplicação do princípio democrático e combate a influência ilícita na edição de regulamentação tributária, que pode acontecer de forma mais significativa na ausência do referido processo. O processo regulamentar permite a elaboração de uma regulamentação transparente, clara suficiente para que o contribuinte a compreenda e a aplique.

Como a Administração Tributária fica em uma posição ainda mais forte diante do contribuinte na edição da regulamentação fiscal no contexto sob comento, o direito ao processo regulamentar também se apresenta como uma medida de boa-fé, uma forma de demonstração do fisco de que somente é exigido do contribuinte o tributo devido conforme o ordenamento jurídico, e não mais do que isso.

Com o debate acerca do conteúdo da regulamentação fiscal e a exposição de motivos para a edição da sua versão final, o processo deve proporcionar uma maior legitimidade da regulamentação editada, o que poderá evitar litígios dependendo dos motivos adotados para edição da regulamentação fiscal final, em uma genuína medida de eficiência administrativa. A possibilidade de o contribuinte expor a sua "norma espelho" e discutir a mesma com a Administração Tributária previamente à edição da regulamentação constitui um mecanismo de participação importante para instalação de um ambiente com maior certeza jurídica, com menos litígios.

Além do caso em que o contribuinte tem o direito à participação e a um processo na edição da regulamentação fiscal quando a Administração Tributária preenche conceitos indeterminados em lei, também existem outros em que esse direito deve ser reconhecido, como os casos em que a lei faz um reenvio à regulamentação ou institui deveres instrumentais. A realidade mostrará como o direito de participação do contribuinte será importante para resguardá-lo de abusos da Administração Tributária, que vai aumentando 
cada vez mais o seu poder. Nada impede que tal processo também seja utilizado na edição de regulamentos interpretativos, que envolvem apenas juízos de legalidade, como forma de prevenir litígios em massa.

$$
(* * *)
$$




\section{BIBLIOGRAFIA}

ALMEIDA, Mário Aroso. Anulação de Actos Administrativos e Relações Jurídicas Emergentes. Coimbra: Almedina, 2002.

AMATUCCI, Andrea. L'Interpretazione della Legge Tributaria. In: (coord.).

Trattato di Diritto Tributario. Padova: Cedam, 1994. Vol. III. P. 547-615.

AMORÓS RICA, Narciso. Interpretacion de las Normas Tributarias. Nueva Enciclopedia Juridica. Barcelona: Editorial Francisco Seix, 1968. t. XIII.

ANDRADE, José Maria Arruda de. Interpretação da Norma Tributária. São Paulo: MP Editora, 2006.

. Decisões Políticas, Legalidade Tributária e Limites da Interpretação. Revista de Direito Tributário da APET, São Paulo, v. 8, p. 95-120, 2005.

; ZAHA, Enio. Programa de Alimentação do Trabalhador (análise do cálculo do incentivo fiscal). Revista Dialética de Direito Tributário, São Paulo, v. 74, p. 25-37, 2001.

ANTONIAZZI, Sandra. Tutela Del Legittimo Affidamento Del Privato nei Confronti della Pubblica Amministrazione. Torino: Giappichelli, 2005.

APRILL, Ellen P. Muffled Chevron: Judicial Review of Tax Regulations. Florida Tax Review. Gainesville, Universidade da Flórida, v. 3, p. 51, 1996.

ARISTÓTELES. A Política. Tradução: Roberto Leal Ferreira. 3. ed. São Paulo: Martins Fontes, 2006.

ATALIBA, Geraldo. Hipótese de Incidência Tributária. 5. ed. São Paulo: Malheiros, 1995.

- Segurança Jurídica. Revista de Direito Tributário, São Paulo, Revista dos Tribunais, n. 60, p. 268-275, abr./jun. 1993. 
Anterioridade da Lei Tributária, Segurança do Direito e Iniciativa Privada. Revista de Direito Mercantil, Industrial, Econômico e Financeiro, São Paulo, Revista dos Tribunais, n. 50, ano XXII, p. 7-25, abr.-jun 1983.

Decreto Regulamentar no Sistema Brasileiro. Revista de Direito Administrativo, Rio de Janeiro, FGV, v. 97, p. 21-33, jul./set. 1969.

ÁVILA, Humberto. Sistema Constitucional Tributário. São Paulo: Saraiva, 2004.

_. Proporcionalidade e Direito Tributário. In: SCHOUERI, Luís Eduardo (coord.) Direito Tributário - Homenagem a Alcides Jorge Costa. Vol. I. São Paulo: Editora Quartier Latin, 2003. p. 329-348.

BACELLAR FILHO, Romeu Felipe. Princípios de Direito Administrativo e Tributação: Fronteiras e Implicações. Revista Trimestral de Direito Público, São Paulo, Malheiros, n. 38, p. 30-36, 2002.

BALEEIRO, Aliomar. Direito Tributário Brasileiro. Atualizadora: Misabel Abreu Machado Derzi. 11. ed. Rio de Janeiro: Editora Forense, 2005.

. Limitações Constitucionais ao Poder de Tributar. Anotado por Misabel de Abreu Machado Derzi. 7. ed. Rio de Janeiro: Editora Forense, 1997.

BANKMAN, Joseph; KLEIN, William A. Federal Income Taxation. 11. ed. Nova Iorque: Aspen Law \& Business, 1997.

BARQUERO ESTEVAN, Juan Manuel. La Función del Tributo en el Estado Social y Democrático de Derecho. Madri: Centro de Estudios Políticos y Constitucionales, 2002.

BARTHOLINI, Salvatore. Il principio di legalitá dei tributi in material di imposte. Padova: Cedam, 1957. 
BASTOS, Celso Ribeiro; MARTINS, Ives Gandra. Comentários à Constituição do Brasil. $4^{0}$ Vol. - tomo I. Arts. 44 a 69. São Paulo: Saraiva, 1995.

BATISTA JÚNIOR, Onofre Alves. A “Governamentalização" do Poder de Decisão Tributário. In: SCHOUERI, Luis Eduardo (coord.) Direito Tributário - Homenagem a Alcides Jorge Costa. Vol. I. São Paulo: Editora Quartier Latin, 2003. p. 394-427.

BECKER, Alfredo Augusto. Teoria Geral do Direito Tributário. 3. ed. São Paulo: Lejus, 1998.

BERCOVICI, Gilberto. Separação de Poderes. Revista de Informação Legislativa, Brasília, Senado Federal, Subsecretaria de Edições Técnicas, v. 150, p. 225-230, abr.jun. 2001.

BIANCO, João Francisco. Segurança Jurídica e o Princípio da Legalidade no Direito Tributário. Revista Direito Tributário Atual do Instituto Brasileiro de Direito Tributário, São Paulo, Editora Dialética, n. 19, p. 16-23, 2005.

BINENBOJM, Gustavo. Uma Teoria de Direito Administrativo. Direitos Fundamentais, Democracia e Constitucionalização. Rio de Janeiro: Renovar, 2006.

BOBBIO, Norberto. O futuro da democracia. São Paulo: Editora Paz e Terra, 2006. Teoria da Norma Jurídica. 2. ed. São Paulo: EDIPRO, 2003. Teoria do Ordenamento Jurídico. 10. ed. Brasília: Editora UnB, 1999. A Era dos Direitos. Rio de Janeiro: Campus, 1992.

BOLAN, Ricardo Ferreira. O Papel da Lei na Criação de Deveres Instrumentais Tributários. Revista Direito Tributário Atual do Instituto Brasileiro de Direito Tributário, São Paulo, Editora Dialética, n. 17, p. 293-302, 2003.

BONAVIDES, Paulo. Teoria do Estado. 7. ed. São Paulo: Malheiros, 2008. 
BORGES. José Souto Maior. Obrigação Tributária (Uma Introdução Metodológica). 2. ed. São Paulo: Malheiros, 1999.

Princípio da Segurança Jurídica na Criação e Aplicação do tributo. Revista de Direito Tributário, São Paulo, Malheiros, n. 63, p. 206-210, 1993.

BOTTAllo, Eduardo Domingos. Curso de Processo Administrativo Tributário. 2. ed. São Paulo: Malheiros, 2009.

—. Teoria da Divisão dos Poderes: Antecedentes Históricos e Principais Aspectos. Revista de Direito da Faculdade de São Bernardo do Campo, São Bernardo do Campo, A Faculdade, n. 14, ano 12, p.127-147, 2008.

BRADFORD, David F. Untangling the Income Tax. Cambridge: Harvard University Press, 1986.

BREYER, Stephen G; STEWART, Richard B.; SUNSTEIN, Cass R.; VERMEULE, Adrian. Administrative Law and Regulatory Policy: Problems, Text and Cases. 6. ed. Nova Iorque: Aspen Publishers, 2006.

BRUNA, Sérgio Varella. Processos Normativos da Administração e Desenvolvimento Econômico. In: SALOMÃO FILHO, Calixto (coord.) Regulação e Desenvolvimento. São Paulo: Malheiros, 2002. p. 231-262.

CANOTILHO, J.J. Gomes. Direito Constitucional. 6. ed. revista. Coimbra: Almedina, 1993.

CARRAZZA, Roque Antonio. Curso de Direito Constitucional Tributário. 25. ed. São Paulo: Malheiros, 2009.

Imposto sobre a Renda (perfil constitucional e temas específicos). São Paulo: Malheiros, 2005. 
O Princípio da Legalidade e a Faculdade Regulamentar no Direito Tributário. In: TORRES, Heleno (coord.) Tratado de Direito Constitucional Tributário: Estudos em Homenagem a Paulo de Barros Carvalho. São Paulo: Saraiva, 2005c. p. 517-533.

- Considerações Acerca da Taxa de Classificação de Produtos Vegetais. Revista Dialética de Direito Tributário, São Paulo, v. 28, p. 84-84, 1998.

. Contribuição Denominada Seguro de Acidentes do Trabalho (SAT). Sua Natureza Tributária - Alíquotas Majoradas por Meio de Decreto - Inviabilidade - Questões Conexas. Revista de Direito Tributário, São Paulo, v. 70, p. 51-79, 1996.

Princípios Constitucionais Tributários e Competência Tributária. São Paulo: Editora Revista dos Tribunais, 1986.

IPTU - Planta de Valores (Valor Venal e Valor Locativo). Revista de Direito Tributário, São Paulo, v. 29/30, p. 127-131, 1984.

- Estudo Sobre os Deveres Instrumentais Tributários. Revista Trimestral de Jurisprudência dos Estados, São Paulo, v. 20, p. 53-64, 1983.

. O Regulamento no Direito Tributário Brasileiro. São Paulo: RT, 1981.

. O Princípio da Igualdade. Justitia, São Paulo, v. 90, p. 337-341, 1975.

CARVAlHO, Paulo de Barros. Direito Tributário, Linguagem e Método. São Paulo: Noeses, 2008.

. Curso de Direito Tributário. 18. ed. São Paulo: Editora Saraiva, 2007.

. O Princípio da Segurança Jurídica no Campo Tributário. Revista de Direito Tributário, São Paulo, Malheiros, n. 94, p. 21-31, 2006.

Crédito-Prêmio de IPI. Estudos e Pareceres. São Paulo: Manole e Minha Editora, 2004a. 
O Princípio da Segurança Jurídica em Matéria Tributária. In: MOREIRA FILHO, Aristóteles; LÔBO, Marcelo Jatobá (coord.) Questões Controvertidas em Matéria Tributária: uma Homenagem ao Professor Paulo de Barros Carvalho. Belo Horizonte: Fórum, 2004b. p. 29-60.

. Notas sobre a Prova no Processo Administrativo Tributário. In: SCHOUERI, Luis Eduardo (coord.). Direito Tributário - Homenagem a Alcides Jorge Costa. Vol. II. São Paulo: Editora Quartier Latin, 2003. p. 855-863.

O Princípio da Segurança Jurídica em Matéria Tributária. Revista de Direito Tributário, São Paulo, Malheiros, n. 61, p. 74-90, 2001.

. Teoria da Norma Tributária. 2. ed. São Paulo: Max Limonad, 2000.

Direito Tributário: Fundamentos Jurídicos da Incidência. 2. ed. São Paulo: Saraiva, 1999.

CASS, R. Sunstein. Beyond Marbury: The Executive's Power to Say What the Law is. Yale Law Journal, New Haven, v. 115, p. 2580, 2006.

CASTRO, Carlos Siqueira. Função Normativa Regulatória e o Novo Princípio da Legalidade. In: ARAGÃO; Alexandre Santos de (coord.). O Poder Normativo das Agências Reguladoras. Rio de Janeiro: Editora Forense, 2006, p. 25-73.

CINTRA, Antonio Carlos de Araújo; GRINOVER, Ada Pellegrini; DINAMARCO, Cândido Rangel. Teoria Geral do Processo. 16. ed. São Paulo: Malheiros, 2000.

CLÈVE, Clèmerson Merlin. Atividade Legislativa do Poder Executivo. 2. ed. São Paulo: Editora Revista dos Tribunais, 2000.

COÊLHO, Sacha Calmon Navarro. Curso de Direito Tributário Brasileiro. Rio de Janeiro: Forense, 1990. 
COMPARATO, Fabio Konder. A Afirmação Histórica dos Direitos Humanos. São Paulo: Saraiva, 2001.

COVERDALE, John F. Court Review of Tax Regulations and Revenue Rulings in the Chevron Era. The George Washington Law Review, Washington, DC, v. 35, p. 64, novembro de 1995.

CRETELla JÚNIOR, J. Manual de Direito Administrativo. 5. ed. Rio de Janeiro: Forense, 1989.

Tratado de Direito Administrativo. Vol. VI Processo Administrativo. Rio de Janeiro: Forense, 1966.

DERZI, Misabel Abreu Machado. Legalidade Material, Modo de Pensar "Tipificante" e Praticidade no Direito Tributário. In: Justiça Tributária (Publicação do $1^{\circ}$ Congresso Internacional de Direito Tributário - IBET). São Paulo: Max Limonad, 1998. p. 627-650.

Direito Tributário, direito penal e tipo. 2. ed. São Paulo: Editora Revista dos Tribunais, 2007.

Mutações, Complexidade, Tipo e Conceito sob o Signo da Segurança Jurídica e da Proteção de Confiança. In: TORRES, Heleno (coord.) Tratado de Direito Constitucional Tributário: Estudos em Homenagem a Paulo de Barros Carvalho. São Paulo: Saraiva, 2005, p. 245-284.

DINAMARCO, Cândido Rangel. A Instrumentalidade do Processo. 7. ed. São Paulo: Malheiros, 1999.

DÓRIA, Antonio Roberto Sampaio. Princípios Constitucionais Tributários e a Cláusula “Due Process of Law”. São Paulo: Revista dos Tribunais, 1964.

DOURADO, Ana Paula. O Princípio da Legalidade Fiscal. Tipicidade, conceitos jurídicos indeterminados e margem de livre apreciação. Coimbra, Almedina, 2007. 
DUARTE, David. A Norma de Legalidade Procedimental Administrativa. A Teoria da Norma e a Criação de Normas de Decisão na Discricionariedade Instrutória. Coimbra: Almedina, 2006.

Procedimentalização, Participação e Fundamentação: Para uma Concretização do Princípio da Imparcialidade Administrativa como Parâmetro Decisório. Coimbra: Almedina, 1996.

DWORKIN, Ronald. Levando os Direitos a Sério. Tradução: Jefferson Luiz Camargo. 2. ed. São Paulo: Martins Fontes, 2007.

O Império do Direito. Tradução: Jefferson Luiz Camargo. São Paulo: Martins Fontes, 2003.

EDLEY JR., Christopher F. Administrative Law. Rethinking Judicial Control of Bureaucracy. New Haven: Yale University Press, 1990.

FALCÃO, Amílcar. Interpretação e Integração da Lei Tributária. Revista de Direito Administrativo, Rio de Janeiro, FGV, n. 40, p. 24-37, abr.-jun. 1955.

FANTOZZI, Augusto. Corso di Diritto Tributario. Torino: UTET, 2005.

FERRAZ, Sergio. Regulamento. In: SANTOS, J.M. de Carvalho (coord.) Repertório Enciclopédico do Direito Brasileiro. Rio de Janeiro: Editor Borsoi, 1972. p. 47-54.

FERRAZ Jr., Tércio Sampaio. O Poder Normativo das Agências Reguladoras à Luz do Princípio da Eficiência. In: ARAGÃO, Alexandre Santos de (coord.). O Poder Normativo das Agências Reguladoras. Rio de Janeiro: Editora Forense, 2006. p. 271-297.

. O Judiciário Frente à Divisão dos Poderes: um Princípio em Decadência? Revista Trimestral de Direito Público, São Paulo, Malheiros, n. 9, p. 40-48, jan./mar. 1995. Introdução ao Estudo do Direito. São Paulo: Atlas, 1991. 
Segurança Jurídica e Normas Gerais Tributárias. Revista de Direito Tributário, São Paulo, Editora Revista dos Tribunais, n. 17-18, p. 51-56, 1981.

FERREIRA, Waldemar. Princípios da Legislação Social e Direito Judiciário do Trabalho. Vol. II. Rio de Janeiro: Freitas Bastos, 1939.

A Justiça do Trabalho. Pareceres proferidos na Comissão de Constituição e Justiça da Câmara dos Deputados. Rio de Janeiro: Câmara dos Deputados, 1937.

FERREIRA FILHO, Manoel Gonçalves. Aspectos do Direito Constitucional Contemporâneo. 2. ed. São Paulo: Saraiva, 2009.

. Do Processo Legislativo. 6. ed. São Paulo: Saraiva, 2007.

Curso de Direito Constitucional. 32. ed. São Paulo: Saraiva, 2006.

FIGUEIREDO, Lúcia Valle. Instrumentos da Administração Consensual. A Audiência Pública e sua Finalidade. Revista Trimestral de Direito Público, São Paulo, Malheiros, n. 38, p. 5-15, 2002.

FORTES, Bonifacio. Delegação Legislativa. Revista de Direito Administrativo, Rio de Janeiro, Faculdade Getúlio Vargas, v. 62, p. 353-387, out./dez.1960.

GARCÍA, Eusébio González. Relaciones entre Los Princípios de Seguridad Jurídica Y Legalidad. In: Justiça Tributária (Publicação do $1^{\circ}$ Congresso Internacional de Direito Tributário - IBET). São Paulo: Max Limonad, 1998. p. 149-164.

- Interpretación de las Normas Tributarias. Revista de Direito Tributário, São Paulo, Malheiros, n. 76, p. 15-30, 1999.

GARCÍA NOVOA, César. El principio de seguridad jurídica en materia tributaria. Madri: Marcial Pons, 2000. 
Seguridad jurídica y Derecho Tributário. In: MELLO, Celso Antônio Bandeira de (org.) Direito Tributário - Estudos em Homenagem a Geraldo Ataliba. São Paulo: Malheiros, 1997. p. 44-73.

GASPARINI. Diogenes. Poder Regulamentar. 2. ed. São Paulo: Editora Revista dos Tribunais, 1982.

GENY, François. O Particularismo do Direito Fiscal. Tradução: Guilherme Augusto dos Anjos. Revista de Direito Administrativo, Rio de Janeiro, Fundação Getúlio Vargas, v. 20, p. 6-31, abr.-jun. 1950.

GODOI, Marciano Seabra de. Justiça, Igualdade e Direito Tributário. São Paulo: Dialética, 1999.

GONÇALVES, José Artur Lima. Isonomia na Norma Tributária. São Paulo: Malheiros, 1993.

GORDILlO, Augustin. Princípios Gerais de Direito Público. Tradução: Marco Aurélio Grecco. São Paulo: Revista dos Tribunais, 1977.

GRAU, Eros Roberto. O Direito Posto e o Direito Pressuposto. 7. ed. São Paulo: Malheiros, 2008.

Ensaio e Discurso sobre a Interpretação/Aplicação do Direito. 3. ed. São Paulo: Malheiros, 2005.

. Conceitos Indeterminados. In: Justiça Tributária (Publicação do $1^{\circ}$ Congresso Internacional de Direito Tributário - IBET). São Paulo: Max Limonad, 1998. p. 119-124.

GRECO, Marco Aurelio. Notas sobre o Princípio da Moralidade. In: SCHOUERI, Luis Eduardo (coord.) Direito Tributário - Homenagem a Alcides Jorge Costa. Vol. I. São Paulo: Quartier Latin, 2003. p. 376-392. 
Planejamento Fiscal e Interpretação da Lei Tributária. São Paulo: Dialética, 1998.

- Três Papéis da Legalidade Tributária. In: RIBEIRO, Ricardo Lodi; ROCHA, Sergio André (coord.) Legalidade e Tipicidade no Direito Tributário. São Paulo: Quartier Latin, 2008, p. 101-110.

GRINOVER, Ada Pellegrini. Os Princípios Constitucionais e o Código de Processo Civil. São Paulo: Bushatsky, 1975.

HAMILTON, Alexander; MADISON, James; e JAY, John. O Federalista. Tradução: Heitor Almeida Herrera. Brasília: Editora Universidade de Brasília, 1984.

HICKMAN, Kristin E. The Need for Mead: Rejecting Tax Exceptionalism in Judicial Deference. Minnesota Law Review, Minneapolis, Universidade de Minnesota, v. 90, p. $1537,2006$.

HORVATH, Estevão. O Princípio do Não-Confisco no Direito Tributário. São Paulo: Dialética, 2002.

IZELLI, Anna Flávia de Azevedo. Limites à Interpretação e Aplicação de Conceitos Jurídicos Indeterminados Presentes na Norma Tributária. 2005. Dissertação (Mestrado) Faculdade de Direito da Universidade de São Paulo, São Paulo, 2005.

JARACH, Dino. Curso Superior de Derecho Tributario. Buenos Aires: Nueva Buenos Aires, 1969.

JELLINEK, G. Teoría general del estado. Tradução: Fernando de los Ríos Urruti. Granada: Editorial Comares, 2000.

JOHNSTON, David Cay. I.R.S. Letting Tax Lawyers Write Rules. The New York Times. Nova Iorque: The New York Times Company, 9/3/2007. Disponível em: http://www.nytimes.com/2007/03/09/business/09tax.html?_r=2\&th=\&emc=th\&pagewan... Acesso em: 11 de janeiro de 2010. 
JUSTEN FILHO, Marçal. Agências Reguladoras e Democracia: Existe um Déficit Democrático na "Regulação Independente"? In: ARAGÃO, Alexandre Santos de (coord.). O Poder Normativo das Agências Reguladoras. Rio de Janeiro: Editora Forense, 2006. p. 301-332.

O Direito das Agências Reguladoras. São Paulo: Dialética, 2002.

KELSEN, Hans. Teoria Geral do Direito e do Estado. Tradução: Luis Carlos Borges. 2. ed. São Paulo: Martins Fontes, 1992.

. Teoria Pura do Direito. Tradução: João Baptista Machado. 3. ed. São Paulo: Martins Fontes, 1991.

LEAL, Victor Nunes. Lei e Regulamento. In: Problemas de Direito Público. Rio de Janeiro: Forense, 1960.

Lei e Regulamento. Revista de Direito Administrativo, Rio de Janeiro, Departamento Administrativo do Serviço Público (Serviço de Documentação), n. 1, p. 371 396, 1945.

LEWANDOWSKI, Enrique Ricardo. Proteção dos Direitos Humanos na Ordem Interna e Internacional. Rio de Janeiro: Forense, 1984.

LIMA, Ruy Cirne. Princípios de Direito Administrativo. 6. ed. São Paulo: Ed. Revista dos Tribunais, 1987.

LOCKE, John. Carta Acerca da Tolerância; Segundo Tratado sobre o Governo; Ensaio Acerca do Entendimento Humano. Tradução: Anoar Aiex e E. Jacy Monteiro. 3. ed. São Paulo: Abril Cultural, 1983.

MACCORMICK, Neil. Institutions of Law: an Essay in Legal Theory. Oxford: Oxford University Press, 2007. 
MACHETE, Pedro. A Audição Prévia do Contribuinte. In: CAMPOS, Diogo Leite de (coord.). Problemas Fundamentais do Direito Tributário. Lisboa: Vislis Editores, 1999. p. 301-335.

MAFFINI, Rafael. Princípio da Proteção Substancial da Confiança no Direito Administrativo Brasileiro. Porto Alegre: Verbo Jurídico, 2006.

MANGANARO, Francesco. Principio di Buona Fede e Attività Delle Amministrazioni Publiche. Napoli: Edizioni Scientifiche Italiane, 1995.

MARTÍNEZ, Joaquín Álvarez. La Motivación de los Actos Tributarios. Barcelona: Marcial Pons, 1999.

MARTINS, Ives Gandra da Silva. O Princípio da Legalidade no Direito Tributário Brasileiro. In: (coord.). Caderno de Pesquisas Tributárias n. 6. Tema: Princípio da Legalidade. São Paulo: CEEU e Editora Resenha Tributária, 1981. p. 325-364.

A Taxa de Controle e Fiscalização Ambiental - TCFA. In: TORRES, Heleno Taveira (coord.). Direito Tributário Ambiental. São Paulo: Malheiros, 2005. p.749-772.

MEDAUAR, Odete. A Processualidade no Direito Administrativo. 2. ed. São Paulo: Editora Revista dos Tribunais, 2008a.

Administração Pública: Do Ato ao Processo. In: ARAGÃO, Alexandre Santos de; MARQUES NETO, Floriano de Azevedo (coord.). Direito Administrativo e seus Novos Paradigmas. Belo Horizonte: Fórum, 2008b. p. 405-419.

O Direito Administrativo em Evolução. 2. ed. São Paulo: Editora Revista dos Tribunais, 2003.

MEDRANO, C. Humberto. El Principio de Seguridad Juridica en la Creación y Aplicación del Tributo. Revista de Direito Tributário, São Paulo, Malheiros, v. 62, p. 133-156, 1993. 
MEIRELLES, Hely Lopes. Direito Administrativo Brasileiro. 31. ed. São Paulo: Malheiros, 2005.

MELIS, Giuseppe. L'Interpretazione nel Diritto Tributario. Padova: CEDAM, 2003.

MELLO, Celso Antônio Bandeira de. Lei e Regulamento - A Chamada "Reserva de Lei" As Delegações Legislativas Disfarçadas. Revista Trimestral de Direito Público, São Paulo, Malheiros, v. 49-50, p. 5-16, 2005.

. Curso de Direito Administrativo. 17. ed. São Paulo: Malheiros, 2004.

Conteúdo Jurídico do Princípio da Igualdade. 3. ed. São Paulo: Malheiros, 1997.

Discricionariedade e Controle Jurisdicional. 2. ed. São Paulo: Malheiros, 1993.

MENDES, Gilmar Ferreira. Proteção Judicial Efetiva dos Direitos Fundamentais. In: LEITE, George Salomão; SARLET, Ingo Wofgang. Direitos Fundamentais e Estado Constitucional: Estudos em Homenagem a J.J. Gomes Canotilho. São Paulo: Editora Revista dos Tribunais; Coimbra (Pt): Coimbra Editora, 2009.

Os Direitos Fundamentais e seus Múltiplos Significados na Ordem Constitucional. Repertório de Jurisprudência IOB, São Paulo, n. 9, Caderno 1, p. 337-333, 1ª Quinzena de maio de 2002.

A Proporcionalidade na Jurisprudência do Supremo Tribunal Federal. Repertório de Jurisprudência IOB, São Paulo, n. 23, Caderno 1, p. 475-469, $1^{\text {a }}$ Quinzena de dezembro de 1994.

MÉNDEZ, Amélia G. Buena Fe Y Derecho Tributário. Madri: Marcial Pons, 2001.

MERKL, Adolfo. Teoría General del Derecho Administrativo. Edição ao cuidado de José Luis Monereo Pérez. Granada: Editorial Comares, S.1., 2004.

MIRABETE, Julio Fabrini. Código Penal Interpretado. São Paulo: Atlas, 1999. 
MIRANDA, Pontes de. Comentários à Constituição de 1967. Com a Emenda n. 1, de 1969. Tomo III (Arts. 32-117). Rio de Janeiro: Forense, 1987.

MONTESQUIEU, Charles de Secondat, Baron de. O Espírito das Leis. Tradução: Cristina Murachco. 3. ed. São Paulo: Martins Fontes, 2005.

MORAES, Alexandre de. Princípio da Eficiência e a Evolução do Controle Jurisdicional dos Atos Administrativos Discricionários. In: LEITE, George Salomão; SARLET, Ingo Wolfgang (coord.). Direitos Fundamentais e Estado Constitucional: Estudos em Homenagem a J.J. Gomes Canotilho. São Paulo: Revista dos Tribunais; Coimbra (Pt.): Coimbra Editora, 2009. p. 417-432.

MOREIRA, Egon Bockmann. Os Limites à Competência Normativa das Agências Reguladoras. In: ARAGÃO, Alexandre Santos de (coord.). O Poder Normativo das Agências Reguladoras. Rio de Janeiro: Editora Forense, 2006. p. 173-220.

MOUSSALlEM, Tárek Moysés. Fontes do Direito Tributário. 2. ed. São Paulo: Noeses, 2006.

NABAIS, José Casalta. O Dever Fundamental de Pagar Impostos. Coimbra: Almedina, 2005.

NERY JUNIOR, Nelson. Princípios do Processo na Constituição Federal: Processo Civil, Penal e Administrativo. 9. ed. São Paulo: Editora Revista dos Tribunais, 2009.

NEUMARK. Fritz. Principios de la Imposición. Madri: Instituto de Estudios Fiscales, 1974.

NOGUEIRA, Ruy Barbosa. Curso de Direito Tributário. 10. ed. São Paulo: Saraiva, 1990.

OLIVEIRA, Carlos Alberto Alvaro. Os Direitos Fundamentais à Efetividade e à Segurança em Perspectiva Dinâmica. In: SALLES, Carlos Alberto (coord.). As Grandes 
Transformações do Processo Civil Brasileiro: Homenagem ao Professor Kazuo Watanabe. São Paulo: Quartier Latin, 2009. p. 32-48.

OLIVEIRA, Ricardo Mariz. Em defesa da Ordem Tributária Institucional. Revista de Direito Bancário e do Mercado de Capitais, São Paulo, Editora Revista dos Tribunais, n. 28, p. 40-45, abr./jun. 2005.

Princípio da Legalidade. In: MARTINS, Ives Gandra (coord.). Caderno de Pesquisas Tributárias n. 6. Tema: Princípio da Legalidade. São Paulo: CEEU e Editora Resenha Tributária, 1981. p. 389-405.

OSVALDO CASÁS, José. Seguridad jurídica, legalidad y legitimidad en la imposición tributaria. In: Justiça Tributária. (Publicação do $1^{\circ}$ Congresso Internacional de Direito Tributário - IBET). São Paulo: Max Limonad, 1998. p. 329-413.

OTERO, Paulo. Legalidade e Administração Pública. O Sentido da Vinculação Administrativa à Juridicidade. Coimbra: Almedina, março de 2007.

PAULSEN, Leandro. Direito Tributário: Constituição e Código Tributário à Luz da Doutrina e da Jurisprudência. 6 ed. rev. atual. Porto Alegre: Livraria do Advogado: ESMAFE, 2004.

PEREZ, Jesus Gonzalez. El Principio General de La Buena Fe en El Derecho Administrativo. Madri: Editorial Civitas, 1983.

PERTENCE, José Paulo Sepulveda. Voto de Liderança. Revista de Direito Público, São Paulo, Revista dos Tribunais, v. 76, p. 57-62, out./dez. 1985.

REAL, Alberto Ramon. Fundamentacion del Acto Administrativo. Revista de Direito Público, São Paulo, Editora Revista dos Tribunais, v. 62, p. 5-20, 1982.

REALE, Miguel. Lições Preliminares de Direito. 23. ed. São Paulo: Saraiva, 1996. 
REESE, John H. Administrative Law. Principles and Practice. St. Paul, Minnesota: West Publishing Co., 1995.

RIBEIRO, Ricardo Lodi; ROCHA, Sérgio André (coord.). Legalidade e Tipicidade no Direito Tributário. São Paulo: Quartier Latin, 2008.

ROCHA, Sergio André. A Deslegalização no Direito Tributário Brasileiro Contemporâneo: Segurança Jurídica, Legalidade, Conceitos Indeterminados, Tipicidade e Liberdade de Conformação da Administração Pública. In: RIBEIRO, Ricardo Lodi; ROCHA, Sergio André (coord.) Legalidade e Tipicidade no Direito Tributário. São Paulo: Quartier Latin, 2008, p. 220-264.

Meios Alternativos de Solução de Conflitos no Direito Tributário Brasileiro. Revista Dialética de Direito Tributário, São Paulo, Editora Dialética, n. 122, p. 90-106, 2005 .

RODRIGUES, Lêda Boechat. História do Supremo Tribunal Federal. Tomo IV Volume I / 1930-1963. Rio de Janeiro: Civilização Brasileira, 2002.

ROSS, Alf. Direito e Justiça. Tradução: Edson Bini. 2. ed. Barueri, SP: EDIPRO, 2007.

ROTHMANN, Gerd W. Preços de Transferência - Método do Preço de Revenda menos Lucro: Base CIF (+II) ou FOB. A Margem de Lucro (20\% ou 60\%) em Processos de Embalagem e Beneficiamento. Revista Dialética de Direito Tributário, São Paulo, Dialética, v. 165, p. 37-56, 2009.

O Princípio da Legalidade Tributária. Revista de Direito Mercantil, Industrial, Econômico e Financeiro, São Paulo, Editora Revista dos Tribunais, n. 8, p. 65-82, 1972.

ROUSSEAU, Jean-Jacques. Do Contrato Social ou Princípios do Direito Político. Tradução: Pietro Nasseti. São Paulo: Editora Martin Claret, 2004. 
RUBIRA, Juan José Lavilla. El Procedimiento de Elaboracion de Los Reglamentos en Los Estados Unidos de America. In: VAZQUEZ, Javier Barnes (coord.) El Procedimiento Administrativo en El Derecho Comparado. Madri: Editorial Civitas, 1993. p. 339-354.

SARAIVA FILHO, Oswaldo Othon de Pontes; GUIMARÃES, Vasco Branco (Org.). Transação e Arbitragem no Âmbito Tributário: homenagem ao jurista Carlos Mário da Silva Velloso. Belo Horizonte: Fórum, 2008.

SARLET, Ingo Wofgang. A Eficácia dos Direitos Fundamentais: uma Teoria Geral dos Direitos Fundamentais na Perspectiva Constitucional. 10. ed. Porto Alegre: Livraria do Advogado Ed., 2009.

(org.). Constituição, Direitos Fundamentais e Direito Privado. 2. ed. Porto Alegre: Livraria do Advogado, 2006.

Algumas Notas sobre o Poder de Reforma da Constituição e seus Limites Materiais no Brasil. In: TORRES, Heleno (coord.). Direito e Poder: nas Instituições e nos Valores do Público e do Privado Contemporâneos. Barueri, SP: Manole, 2005.

SARMENTO. Daniel. O Neoconstitucionalismo no Brasil: Riscos e Possibilidades. In: LEITE, George Salomão; SARLET, Ingo Wolfgang (coord.). Direitos Fundamentais $e$ Estado Constitucional. Estudos em Homenagem a J.J. Gomes Canotilho. São Paulo: Revista dos Tribunais; Coimbra (Pt): Coimbra Editora, 2009. p. 9-49.

SCHOUERI, Luís Eduardo. Preços de Transferência no Direito Tributário Brasileiro. 2. ed. São Paulo: Dialética, 2006.

Contribuição à Investigação das Origens do Princípio da Legalidade em Matéria Tributária. In: VELLOSO, Carlos Mário da Silva; ROSAS, Roberto; AMARAL, Antonio Carlos Rodrigues (coord.). Princípios Constitucionais Fundamentais. Estudos em Homenagem ao Professor Ives Grandra da Silva Martins. São Paulo: Lex Editora, 2005a. p. 711-718. 
Normas Tributárias Indutoras e Intervenção Econômica. Rio de Janeiro: Forense, $2005 b$

A Suave Perda da Liberdade. Revista Direito Tributário Atual, Instituto Brasileiro de Direito Tributário, São Paulo, Editora Dialética, v. 18, p. 7-10, 2004.

SILVA, Almiro do Couto. Princípios da Legalidade da Administração Pública e da Segurança Jurídica no Estado de Direito Contemporâneo. Revista de Direito Público, São Paulo, Editora Revista dos Tribunais, v. 84, p. 46-63, 1987.

SILVA, José Afonso. Curso de Direito Constitucional Positivo. 28. ed., revista e atualizada. São Paulo: Malheiros, 2007.

SILVEIRA, Paulo Fernando. Devido Processo Legal. Due Processo $f$ Law. Belo Horizonte: Del Rey, 1996.

SILVEIRA, Rodrigo Maitto. Aplicação de Tratados Internacionais contra a Bitributação - Qualificação de Partnership Joint Ventures. São Paulo: Quartier Latin, 2006. Série Doutrina Tributária. Vol. I.

SMITH, Adam. Inquérito sobre a Natureza e as Causas da Riqueza das Nações. Volumes I e II. Tradução e notas de Luís Cristóvão de Aguiar. $5^{\mathrm{a}}$ e $4^{\mathrm{a}}$ edição, respectivamente. Fundação Calouste Gulbenkian: Lisboa, 2006.

SOUTO, Marcus Juruena Villela. Audiência Pública e Regulação. Revista de Direito Público da Economia - RDPE, Belo Horizonte, Editora Fórum, v. 4, p. 145-167, 2003.

STRAUSS, Peter L. Within Marbury: the Importance of Judicial Limits on the Executive's Power to Say What the Law Is. Yale Law Journal, New Haven, vol. 116, p. 59, 2006.

STRAUSS, Peter L.; RAKOFF, Todd; FARINA, Cynthia R. 1999 Supplement to Gellhorn and Byse's Administrative Law, Cases and Comments. 9. ed. Nova Iorque: The Foundation Press, Inc., 1999. 
STRAUSS, Peter L.; RAKOFF, Todd; SCHOTLAND, Roy A.; FARINA, Cynthia R. Gellhorn and Byse's Administrative Law, Cases and Comments. 9. ed. Nova Iorque: The Foundation Press, Inc., 1995.

STRECK, Lenio Luiz. Uma Abordagem Hermenêutica acerca do Triângulo Dialético de Canotilho ou de como ainda é Válida a Tese da Constituição Dirigente (Adequada a Países de Modernidade Tardia). In: LEITE, George Salomão; SARLET, Ingo Wolfgang (coord.). Direitos Fundamentais e Estado Constitucional. Estudos em Homenagem a J.J. Gomes Canotilho. São Paulo: Revista dos Tribunais; Coimbra (Pt): Coimbra Editora, 2009, p. 5078.

SUNDFELD, Carlos Ari. Processo e Procedimento Administrativo no Brasil. In: SUNDFELD, Carlos Ari; MUÑOZ, Guillermo Andrés (coord.). As Leis de Processo Administrativo - Lei Federal 9.784/99 e Lei Paulista 10.177/98. São Paulo: Malheiros, 2000. p. 17-36.

Fundamentos de Direito Público. 3. ed. São Paulo: Malheiros. 1997.

A Importância do Procedimento Administrativo. Revista de Direito Público, São Paulo: Revista dos Tribunais, v. 84, p. 64-74, 1987.

. Motivação do Ato Administrativo como Garantia dos Administrados. Revista de Direito Público, São Paulo, Editora Revista dos Tribunais, v. 75, p. 118-127, 1985.

TÁCITO, Caio. Comissão de Valores Mobiliários. Poder Regulamentar. In: Temas de Direito Público (Estudos e Pareceres). $2^{\circ}$ Volume. Rio de Janeiro: Renovar, 1997. p. 1075-1093.

TIPKE, Klaus. A Necessidade de Igualdade na Execução das Leis Tributárias. Tradução: Luís Eduardo Schoueri. In: SCHOUERI, Luís Eduardo (coord.). Direito TributárioHomenagem a Alcides Jorge Costa. Vol. I. São Paulo: Quartier Latin, 2003. p. 362-373.

Moral Tributaria del Estado Y de Los Contribuyentes (Besteuerungsmoral und Steuermoral). Tradução: Pedro M. Herrera Molina. Madri: Marcial Pons, 2002. 
. Sobre a Unidade da Ordem Jurídica Tributária. Tradução: Luís Eduardo Schoueri. In: SCHOUERI, Luís Eduardo; ZILVETI, Fernando Aurelio (coord.). Direito tributário: estudos em homenagem a Brandão Machado. São Paulo: Dialética, 1998. p. 60-70.

. Princípio de Igualdade e Ideia de Sistema no Direito Tributário. Tradução: Brandão Machado. In: MACHADO, Brandão (coord.). Direito Tributário: Estudos em Homenagem ao Prof. Ruy Barbosa Nogueira. São Paulo: Saraiva, 1984. p. 449-514.

TORRES, Heleno Taveira. Princípios de Segurança Jurídica e Transação em Matéria Tributária. Os Limites da Revisão Administrativa dos Acordos Tributários. In: SARAIVA FILHO, Oswaldo Othon de Pontes; GUIMARÃES, Vasco Branco (orgs.). Transação $e$ Arbitragem no Âmbito Tributário: homenagem ao jurista Carlos Mário da Silva Velloso. Belo Horizonte: Fórum, 2008. p. 299-330.

Interpretação e Integração das Normas Tributárias - Reflexões Críticas. In: (coord.). Tratado de Direito Constitucional Tributário: Estudos em Homenagem a Paulo de Barros Carvalho. São Paulo: Saraiva, 2005a. p. 111-148.

Conflitos de Fontes e de Normas no Direito Tributário - O Princípio da Segurança Jurídica na Formação da Obrigação Tributária. In: (coord.). Teoria Geral da Obrigação Tributária: Estudos em Homenagem ao Professor Souto Maior Borges. São Paulo: Malheiros, 2005b. p. 111-160.

Imposto de Importação e o Acordo de Valoração Aduaneira. Ajustes do Valor de Transação com Royalties e Serviços. In: (coord.) Direito Tributário Internacional Aplicado. Vol. II. São Paulo: Quartier Latin, 2004. p. 180-236.

- Transação, arbitragem e conciliação judicial como medidas alternativas para resolução de conflitos entre Administração e contribuintes - simplificação e eficiência administrativa. Revista Fórum de Direito Tributário, Belo Horizonte, Fórum, n. 2, p. 91126, mar.-abr./2003a. 
Direito Tributário e Direito Privado: Autonomia Privada : Simulação : Elusão Tributária. São Paulo: Editora Revista dos Tribunais, 2003.

Contribuições da Doutrina Italiana para a Formação do Direito Tributário Brasileiro. In: SCHOUERI, Luis Eduardo (coord.). Direito Tributário - Homenagem a Alcides Jorge Costa. Vol. II. São Paulo: Editora Quartier Latin, 2003c. p. 1148-1167.

TORRES, Ricardo Lobo. Interação entre Princípios Constitucionais Tributários e Princípios da Ordem Econômica. In: FERRAZ, Roberto (coord.). Princípios e Limites da Tributação 2 - Os Princípios da Ordem Econômica e a Tributação. São Paulo: Quartier Latin, 2009. p. 493-516.

Tratado de Direito Constitucional Financeiro e Tributário. Volume II. Valores e Princípios Constitucionais Tributários. Rio de Janeiro: Editora Renovar, 2005.

A Legitimação da Capacidade Contributiva e dos Direitos Fundamentais do Contribuinte. In: SCHOUERI, Luís Eduardo (coord.). Direito Tributário - Vol. I. Homenagem a Alcides Jorge Costa. São Paulo: Quartier Latin, inverno de 2003. p. 430456.

Processo Administrativo Fiscal: caminhos para o seu desenvolvimento. Revista Dialética de Direito Tributário, São Paulo, Editora Dialética, n. 46, p. 78-83, 1999.

. A Ideia de Liberdade no Estado Patrimonial e no Estado Fiscal. Rio de Janeiro: Renovar, 1991.

O Princípio da Tipicidade no Direito Tributário. Revista de Direito Administrativo, Rio de Janeiro, Editora Renovar, n. 235, p. 193-232, jan.-mar. 2004.

O Princípio da Tipicidade no Direito Tributário. Revista de Direito Tributário Atual, São Paulo, Editora Dialética, n. 18, p. 23-51, 2004. 
TROTABAS, Louis. Ensaio sobre o Direito Fiscal. Tradução: Guilherme Augusto dos Anjos. Revista de Direito Administrativo, Rio de Janeiro, Fundação Getúlio Vargas, v. 26, p. 34-59, out.-dez. 1951.

UCKMAR, Victor. Princípios Comuns do Direito Constitucional Tributário. Tradução: Marco Aurélio Greco. São Paulo: Editora Revista dos Tribunais, 1976.

VELloso, Carlos Mário da Silva. Do Poder Regulamentar. Revista de Direito Público, São Paulo, Editora Revista dos Tribunais, v. 65, p. 39-50, 1983.

VIANNA, Oliveira. Problemas de Direito Corporativo. Introdução de Alberto Venâncio Filho. 2. ed. Brasília: Câmara dos Deputados, Coordenação de publicações, 1983.

VILLEGAS, Héctor. Principio de Seguridad Jurídica en la Creación y Aplicación del Tributo - El Contenido de la Seguridad Jurídica. Revista de Direito Tributário, São Paulo, RT, v. 66, p. 7-16, 1995.

WATSON, Camilla E; BILlMAN, Jr. Brookes D. Federal Tax Practice and Procedure. Saint Paul: West Publishing, 2005.

WORLD ECONOMIC FORUM. The Brazil Competitiveness Report 2009. Genebra: World Economic Forum, 2009. The Global Competitiveness Report 2008/2009. Genebra: World Economic Forum, 2008.

XAVIER, Alberto. Direito Tributário Internacional do Brasil. 6. ed. Rio de Janeiro: Forense, 2004.

Tipicidade da tributação, simulação e norma antielisiva. São Paulo: Editora Dialética, 2001. . Os Princípios da Legalidade e da Tipicidade da Tributação. São Paulo: RT, 1978. 
ZOLO, Danilo. Teoria e Crítica do Estado de Direito. Tradução: Carlo Alberto Dastoli. In: ZOLO, Danilo; COSTA, Pietro (org.). O Estado de Direito - História, Teoria, Crítica. São Paulo: Martins Fontes, 2006. p. 3-94.

$$
(* * *)
$$

